Prepared in cooperation with the National Park Service

\title{
Analysis of the Shallow Groundwater Flow System at Fire Island National Seashore, Suffolk County, New York
}

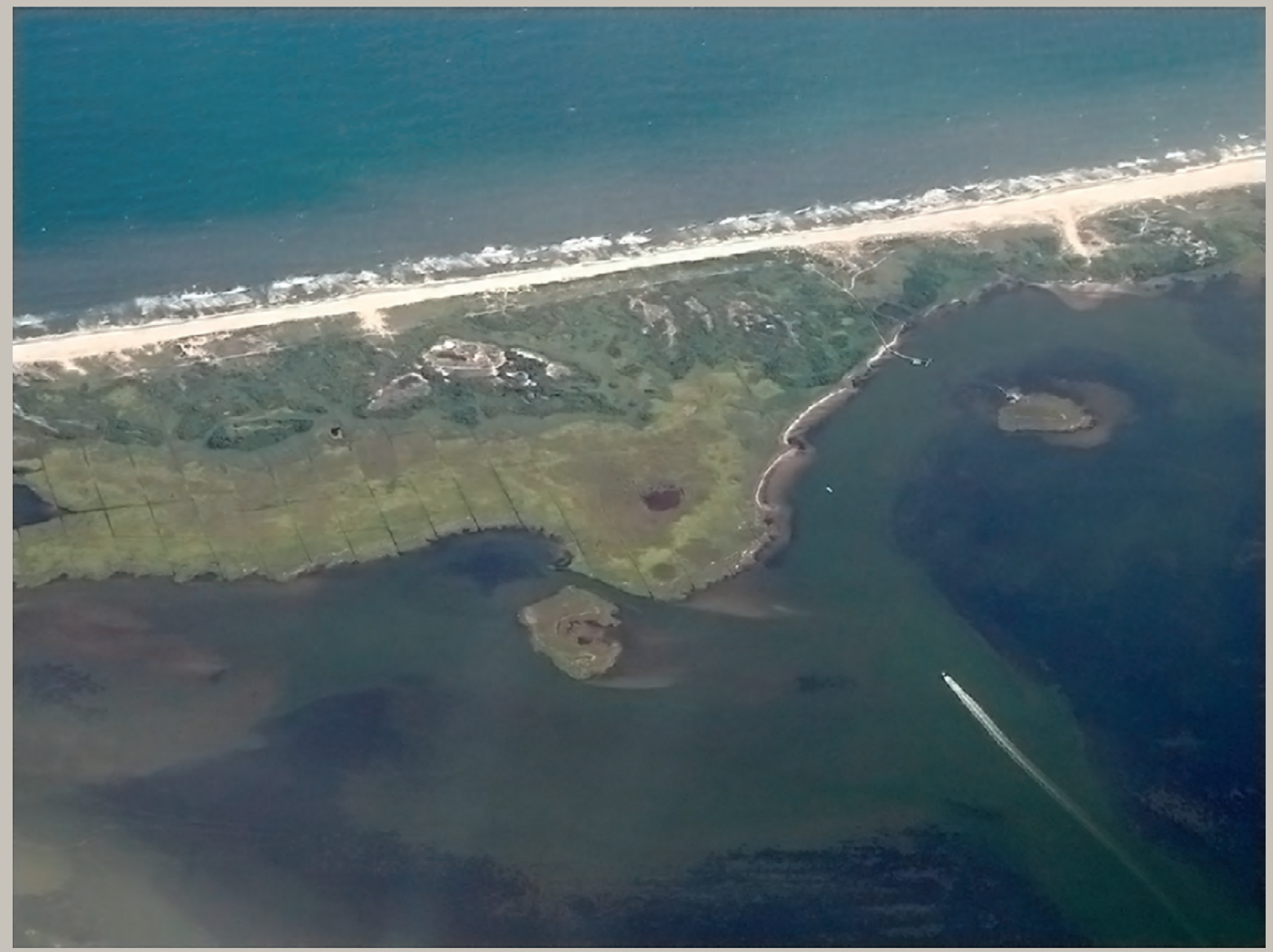

Scientific Investigations Report 2009-5259 
Cover. Aerial photograph of Old Inlet vicinity of Otis Pike Fire Island High Dune Wilderness in Fire Island National Seashore, Suffolk County, N.Y. (Photograph courtesy of James Lynch, U.S. Geological Survey) 


\section{Analysis of the Shallow Groundwater Flow System at Fire Island National Seashore, Suffolk County, New York}

By Christopher E. Schubert

Prepared in cooperation with the National Park Service

Scientific Investigations Report 2009-5259 


\section{U.S. Department of the Interior \\ KEN SALAZAR, Secretary \\ U.S. Geological Survey \\ Marcia K. McNutt, Director}

U.S. Geological Survey, Reston, Virginia: 2010

For more information on the USGS - the Federal source for science about the Earth, its natural and living resources, natural hazards, and the environment, visit http://www.usgs.gov or call 1-888-ASK-USGS

For an overview of USGS information products, including maps, imagery, and publications, visit http://www.usgs.gov/pubprod

To order this and other USGS information products, visit http://store.usgs.gov

Any use of trade, product, or firm names is for descriptive purposes only and does not imply endorsement by the U.S. Government.

Although this report is in the public domain, permission must be secured from the individual copyright owners to reproduce any copyrighted materials contained within this report.

Suggested citation:

Schubert, C.E., 2010, Analysis of the shallow groundwater flow system at Fire Island National Seashore, Suffolk County, New York: U.S. Geological Survey Scientific Investigations Report 2009-5259, 106 p. (Also available at http://pubs.usgs.gov/sir/2009/5259.) 


\section{Contents}

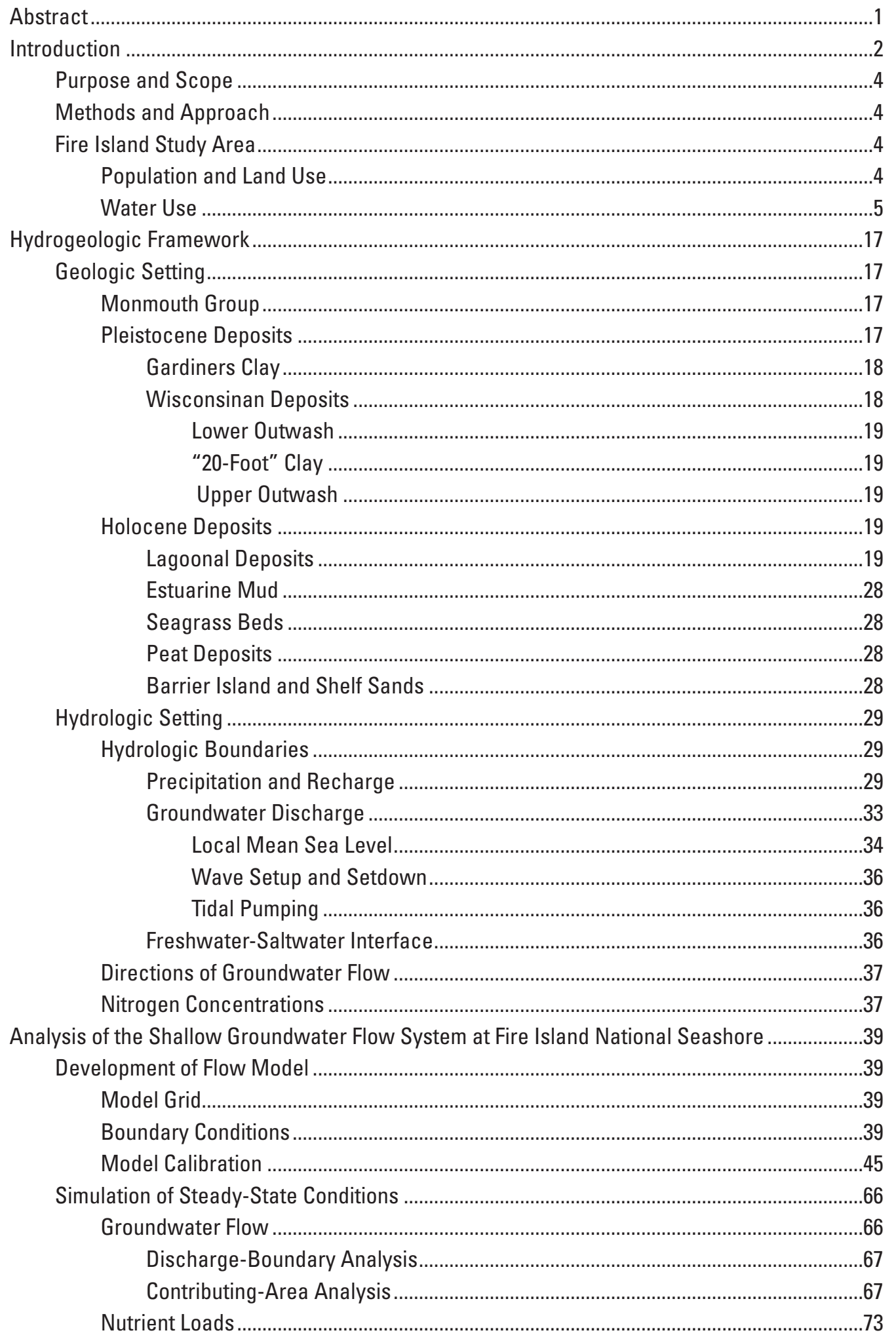


Groundwater-Resource Concerns........................................................................................ 89

Use of Long-Term Monitoring to Assess Water Resources ....................................................94

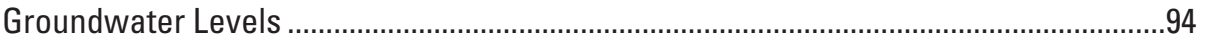

Water-Quality Samples .............................................................................................95

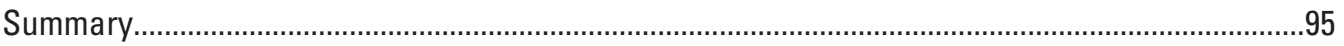

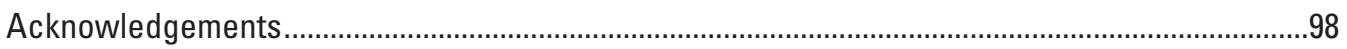

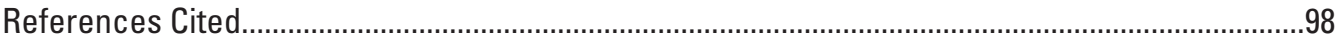

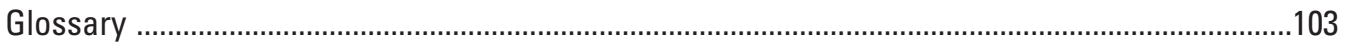

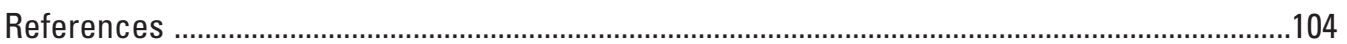

Appendix 1. Groundwater Levels Collected at Fire Island National Seashore, October 2005 through October 2006.................................................................................................. 105

Appendix 2. Dissolved Inorganic Nitrogen (Ammonia, Nitrite, and Nitrite Plus Nitrate) and Phosphorus (Orthophosphate) Concentrations in Groundwater Collected at Fire Island National Seashore, October 2005 through September 2006

\section{Figures}

1. Map showing location of Suffolk County study area on Long Island, N.Y., tide-stage gaging station 01310740 Reynolds Channel at Point Lookout, N.Y., and selected tidal benchmarks in southeastern New York and northern New Jersey

2. Map showing location of Fire Island National Seashore, selected precipitation-measurement stations and tidal benchmarks, vertical section $A-A^{\prime}$, and Fire Island study area in Suffolk County, N.Y.

3. Maps showing land use and locations of local study areas in the Fire Island study area, Suffolk County, N.Y.

4. Maps showing locations of observation wells and vertical sections B-B' through $\mathrm{E}-\mathrm{E}^{\prime}$ in local study areas and groundwater levels during October 31-November 1, 2005, on Fire Island, Suffolk County, N.Y.

5. Diagrams showing gamma-ray and electromagnetic-induction logs, salinity from filter-press core samples, generalized sediment description from core samples, and corresponding geologic units for borings at four wells on Fire Island, Suffolk County, N.Y., (A) well 126753, (B) well 126000, (C) well 125990, and (D) well 124399........12

6. Maps showing locations of public water-supply systems and selected wastewater-disposal systems on Fire Island, Suffolk County, N.Y.

7. Diagrams showing generalized vertical section $A-A^{\prime}$ showing major hydrogeologic units and approximate distribution and flow directions of fresh and saline groundwater along $(A)$ the southern shore of Long Island and $(B)$ on Fire Island, N.Y.

8. Diagrams showing vertical sections $B-B^{\prime}$ through $E-E^{\prime}$ showing hydrogeologic units, freshwater-saltwater interface, and wells with screened intervals in local study areas, and water-table altitude and groundwater levels during October 31-November 1, 2005, on Fire Island, Suffolk County, N.Y.

9. Maps showing altitude of upper surface of Gardiners Clay and, where absent, Monmouth greensand in the Fire Island study area, Suffolk County, N.Y. (Upper-surface altitudes of Gardiners Clay and Monmouth greensand from Smolensky and others, 1989 , sheet 3. 
10. Maps showing altitude of upper surface of "20-foot" clay in the Fire Island study area, Suffolk County, N.Y.

11. Maps showing thickness of "20-foot" clay in the Fire Island study area, Suffolk County, N.Y.

12. Maps showing generalized land cover and substrate on Fire Island and adjacent islands within Fire Island National Seashore, and benthic habitats in back-bay areas of the Fire Island study area, Suffolk County, N.Y.

13. Photograph of ocean shore between Watch Hill and Davis Park showing peat deposits occasionally uncovered on the Atlantic 0cean beaches of Fire Island, Suffolk County, N.Y.

14. Graph showing long-term mean monthly evaporation at land pans in Greenport and Mineola, Long Island, N.Y.

15. Graphs showing continuous water-level records and synoptic water-level measurements at selected wells on Fire Island, and daily higher high water values at tide-stage gaging station 01310740 Reynolds Channel at Point Lookout, N.Y., during October 2005-April 2007, Long Island, N.Y.

16. Maps showing total nitrogen concentrations at 35 wells sampled during 0 ctober 2005 on Fire Island, Suffolk County, N.Y.

17. Graph showing total nitrogen concentrations at four wells sampled during October 2005 and March and August-September 2006 on Fire Island, Suffolk County, N.Y.

18. Maps showing active and inactive areas and locations of columns 190, 255, 569, and 790 in the model of Fire Island study area, Suffolk County, N.Y.

19. Graphs showing modeled hydrogeologic units for active model cells along four selected columns in the Fire Island study area, Suffolk County, N.Y. (A) column 190, (B) column 255, (C) column 569, and (D) column 790

20. Maps showing modeled hydrogeologic units for layer 1 in the Fire Island study area, Suffolk County, N.Y.

21. Maps showing modeled hydrogeologic units for layer 2 in the Fire Island study area, Suffolk County, N.Y.

22. Maps showing modeled hydrogeologic units for layers $3 \mathbf{- 5}$ in the Fire Island study area, Suffolk County, N.Y.

23. Maps showing modeled hydrogeologic units for layer 9 in the Fire Island study area, Suffolk County, N.Y.

24. Maps showing modeled, constant hydraulic-head values in the Fire Island study area, Suffolk County, N.Y.

25. Maps showing modeled, constant salt-concentration values in the Fire Island study area, Suffolk County, N.Y.

26. Maps showing zones and rates of recharge from precipitation simulated in the model of Fire Island study area, Suffolk County, N.Y.

27. Maps showing rates of recharge from the return flow of public-supply water simulated in the model of Fire Island study area, Suffolk County, N.Y.

28. Maps showing simulated 2005 mean annual water-table altitude and extent of unconfined freshwater flow system within surficial hydrogeologic units in the model of Fire Island study area, Suffolk County, N.Y.

29. Maps showing sSimulated 2005 mean annual potentiometric-surface altitude and extent of confined freshwater flow system beneath peat deposits onshore and surficial Holocene units offshore in the model of Fire Island study area, Suffolk County, N.Y. 
30. Maps showing simulated 2005 mean annual potentiometric-surface altitude and extent of confined freshwater flow system beneath "20-foot" clay and (or) upper outwash in the model of Fire Island study area, Suffolk County, N.Y...

31. Diagrams showing simulated 2005 mean annual water levels, flow vectors, and extent of freshwater within the shallow aquifer system along four selected columns in the Fire Island study area, Suffolk County, N.Y. (A) column 190, (B) column 255, (C) column 569, and (D) column 790

32. Maps showing simulated 2005 mean annual groundwater flows between the shallow aquifer system and marine surface waters, and recharge areas for fresh-groundwater budgets (tables 13 and 14) and total nitrogen loads (table 15) in the model of Fire Island study area, Suffolk County, N.Y.

33. Maps showing simulated contributing areas to marine surface waters under 2005 mean annual conditions in the model of Fire Island study area, Suffolk County, N.Y.

\section{Tables}

1. Monthly pumpage in 2005 for public water-supply systems on Fire Island, Suffolk County, N.Y.

2. Generalized description of geologic and hydrogeologic units in the Fire Island study area, Suffolk County, N.Y.

3. Annual and long-term mean precipitation amounts at Patchogue and Islip, Suffolk County, N.Y.

4. Published relations between tidal and fixed datums for 1983-2001 tidal epoch at six active National Ocean Service tidal benchmark stations in southeastern New York and northeastern New Jersey.

5. Published relations and calculated difference between National Geodetic Vertical Datum of 1929 and local mean low water datum for the 1941-59 and 1983-2001 tidal epochs at four active National Ocean Service tidal benchmark stations in southeastern New York and northeastern New Jersey.

6. Published and calculated relations between local mean low water and mean tide level datums and National Geodetic Vertical Datum of 1929 for the 1941-59 tidal epoch, and estimated difference for and relation between mean tide level and National Geodetic Vertical Datum of 1929 for the 1983-2001 tidal epoch at selected discontinued National Ocean Service tidal benchmark stations, Suffolk County, N.Y.

7. Relations and calculated difference between mean sea level datum and National Geodetic Vertical Datum of 1929 for the 1983-2001 tidal epoch and from the VDatum program at the National Ocean Service tidal benchmark station at Sandy Hook, N.J.

8. Simulated zones of recharge from precipitation in the model of Fire Island study area, Suffolk County, N.Y.

9. Differences between measured and simulated water levels at wells in four areas of Fire Island, Suffolk County, N.Y.

10. Differences between measured and simulated water levels at wells screened in four hydrogeologic units simulated in the model of Fire Island, Suffolk County, N.Y......71

11. Measured and simulated water levels and vertical hydraulic gradients at five observation-well pairs on Fire Island, Suffolk County, N.Y. 
12. Final horizontal and vertical hydraulic conductivities for hydrogeologic units simulated in the model of Fire Island study area, Suffolk County, N.Y.

13. Simulated 2005 mean annual fresh-groundwater budgets for recharge areas of similar land use from the discharge-boundary analysis of Fire Island study area, Suffolk County, N.Y.

14. Simulated 2005 mean annual fresh-groundwater budgets for recharge areas of similar land use from the contributing-area analysis of Fire Island study area, Suffolk County, N.Y..

15. Calculated total nitrogen loads to marine surface waters for recharge areas of similar land use in the model of Fire Island study area, Suffolk County, N.Y.

16. Annual totals and rates of nitrogen loading from shallow groundwater to marine surface waters from three watersheds on Long Island, N.Y. 


\section{Conversion Factors, Datums, and Abbreviations}

\begin{tabular}{|c|c|c|}
\hline Multiply & By & To obtain \\
\hline \multicolumn{3}{|c|}{ Length } \\
\hline centimeter $(\mathrm{cm})$ & 0.3937 & inch (in.) \\
\hline meter $(\mathrm{m})$ & 3.281 & foot $(\mathrm{ft})$ \\
\hline kilometer $(\mathrm{km})$ & 0.6214 & mile (mi) \\
\hline kilometer $(\mathrm{km})$ & 0.5400 & mile, nautical (nmi) \\
\hline meter $(\mathrm{m})$ & 1.094 & $\operatorname{yard}(\mathrm{yd})$ \\
\hline \multicolumn{3}{|c|}{ Area } \\
\hline square meter $\left(\mathrm{m}^{2}\right)$ & 0.0002471 & acre \\
\hline hectare (ha) & 2.471 & acre \\
\hline square hectometer $\left(\mathrm{hm}^{2}\right)$ & 2.471 & acre \\
\hline square kilometer $\left(\mathrm{km}^{2}\right)$ & 247.1 & acre \\
\hline square kilometer $\left(\mathrm{km}^{2}\right)$ & 0.3861 & square mile $\left(\mathrm{mi}^{2}\right)$ \\
\hline \multicolumn{3}{|c|}{ Volume } \\
\hline liter (L) & 33.82 & ounce, fluid (fl. oz) \\
\hline $\operatorname{liter}(\mathrm{L})$ & 2.113 & pint $(\mathrm{pt})$ \\
\hline liter $(\mathrm{L})$ & 1.057 & quart (qt) \\
\hline liter $(\mathrm{L})$ & 0.2642 & gallon (gal) \\
\hline \multicolumn{3}{|c|}{ Flow rate } \\
\hline centimeter per year $(\mathrm{cm} / \mathrm{yr})$ & 0.3937 & inch per year (in/yr) \\
\hline meter per day $(\mathrm{m} / \mathrm{d})$ & 3.281 & foot per day $(\mathrm{ft} / \mathrm{d})$ \\
\hline cubic meter per day $\left(\mathrm{m}^{3} / \mathrm{d}\right)$ & 35.31 & cubic foot per day $\left(\mathrm{ft}^{3} / \mathrm{d}\right)$ \\
\hline liter per second $(\mathrm{L} / \mathrm{s})$ & 15.85 & gallon per minute (gal/min) \\
\hline \multicolumn{3}{|c|}{ Mass } \\
\hline kilogram $(\mathrm{kg})$ & 2.205 & pound avoirdupois (lb) \\
\hline kilogram per year $(\mathrm{kg} / \mathrm{yr})$ & 2.205 & pound per year $(\mathrm{lb} / \mathrm{yr})$ \\
\hline kilogram per square kilometer $\left(\mathrm{kg} / \mathrm{km}^{2}\right)$ & 5.711 & pound per square mile $\left(\mathrm{lb} / \mathrm{mi}^{2}\right)$ \\
\hline
\end{tabular}

Temperature in degrees Celsius $\left({ }^{\circ} \mathrm{C}\right)$ may be converted to degrees Fahrenheit $\left({ }^{\circ} \mathrm{F}\right)$ as follows:

$$
{ }^{\circ} \mathrm{F}=\left(1.8 \times^{\circ} \mathrm{C}\right)+32
$$

Vertical coordinate information is referenced to National Geodetic Vertical Datum of 1929 (NGVD 29).

Horizontal coordinate information is referenced to the North American Datum of 1983 (NAD 83). Altitude, as used in this report, refers to distance above the vertical datum.

Specific conductance is given in microsiemens per centimeter at 25 degrees Celsius $\left(\mu \mathrm{S} / \mathrm{cm}\right.$ at $\left.25^{\circ} \mathrm{C}\right)$.

Concentrations of chemical constituents in water are given in milligrams per liter (mg/L). 


\section{List of Acronyms}

$\begin{array}{ll}\text { FIIS } & \text { Fire Island National Seashore } \\ \text { GIS } & \text { Geographic information system } \\ \text { MHHW } & \text { Mean higher high water } \\ \text { MLW } & \text { Mean low water } \\ \text { MLLW } & \text { Mean lower low water } \\ \text { MSL } & \text { Mean sea level } \\ \text { MTL } & \text { Mean tide level } \\ \text { NPS } & \text { National Park Service } \\ \text { NCDC } & \text { National Climatic Data Center } \\ \text { NOS } & \text { National Ocean Service } \\ \text { SSER } & \text { South Shore Estuary Reserve } \\ \text { SCDHS } & \text { Suffolk County Department of Health Services } \\ \text { SCDP } & \text { Suffolk County Department of Planning } \\ \text { SCWA } & \text { Suffolk County Water Authority } \\ \text { TN } & \text { Total nitrogen } \\ \text { USGS } & \text { U.S. Geological Survey }\end{array}$


This page has been left blank intentionally. 


\title{
Analysis of the Shallow Groundwater Flow System at Fire Island National Seashore, Suffolk County, New York
}

\author{
By Christopher E. Schubert
}

\section{Abstract}

Fire Island National Seashore (FIIS) occupies 42 kilometers of the barrier island for which it is named that lies off the southern shore of Suffolk County, N.Y. Freshwater ${ }^{1}$ in the highly permeable, sandy aquifer underlying Fire Island is bounded laterally by marine surface waters and at depth by saline groundwater. Interspersed throughout FIIS are 17 pre-existing residential communities that in summer months greatly increase in population through the arrival of summer residents and vacationers; in addition, the National Park Service (NPS) has established several facilities on the island to accommodate visitors to FIIS. The 2.2 million people estimated by the NPS to visit Fire Island annually impact groundwater quality through the release of waste-derived contaminants, such as nutrients, pathogens, and organic compounds, into the environment. Wastecontaminated groundwater can move through the aquifer and threaten the ecological health of the adjacent back-barrier estuaries to which much of the groundwater ultimately discharges. In 2004, the U.S. Geological Survey (USGS), in cooperation with the NPS, began a 3-year investigation to (1) collect groundwater levels and water-quality (nutrient) samples, (2) develop a three-dimensional model of the shallow (water-table) aquifer system and adjacent marine surface waters, and (3) calculate nitrogen loads in simulated groundwater discharges from the aquifer to back-barrier estuaries and the ocean.

The hydrogeology of the shallow aquifer system was characterized from the results of exploratory drilling, geophysical surveying, water-level monitoring, and waterquality sampling. The investigation focused on four areasthe communities of Kismet and Robbins Rest, the NPS Visitor Center at Watch Hill, and the undeveloped Otis Pike Fire Island High Dune Wilderness. Thirty-five observation wells were installed within FIIS to characterize subsurface hydrogeology and establish a water-table monitoring network in the four study areas. A variable-density model of the shallow aquifer system and adjacent marine surface waters was developed to simulate groundwater flow patterns and rates. Nitrogen loads from the shallow aquifer system

${ }^{1}$ Bold text is defined in the glossary. were calculated from representative total nitrogen (TN) concentrations and simulated groundwater discharges to backbarrier estuaries and the ocean.

The model simulates groundwater directions, velocities, and discharge rates under 2005 mean annual conditions. Groundwater budgets were developed for recharge areas of similar land use that contribute freshwater to back-barrier estuaries, the ocean, and subsea-discharge zones. Total freshwater discharge from the shallow aquifer system is about 43,500 cubic meters per day $\left(\mathrm{m}^{3} / \mathrm{d}\right)(79.8$ percent $)$ to backbarrier estuaries and about $10,200 \mathrm{~m}^{3} / \mathrm{d}(18.7$ percent) to the ocean; about $836 \mathrm{~m}^{3} / \mathrm{d}$ (1.5 percent) may exit the system as subsea underflow. The total contribution of fresh groundwater to shoreline discharge zones amounts to about $53,700 \mathrm{~m}^{3} / \mathrm{d}$ ( 98.5 percent). The median age of freshwater discharged to back-barrier estuaries and the ocean was 3.4 years, and the $95^{\text {th }}$-percentile age was 20 years.

The TN concentrations and loads under 2005 mean annual conditions for areas that contribute fresh groundwater to back-barrier estuaries and the ocean were calculated for the principal land uses on Fire Island. The overall TN load from the shallow aquifer system to shoreline discharge zones is about 16,200 kilograms per year ( $\mathrm{kg} / \mathrm{yr})$ (82.2 percent) to back-barrier estuaries and about 3,500 kg/yr (17.8 percent) to the ocean. The overall $\mathrm{TN}$ load to marine surface waters amounts to about $19,700 \mathrm{~kg} / \mathrm{yr}$ - roughly 6 percent of the annual TN load from shallow groundwater entering the South Shore Estuary Reserve (SSER) from the Suffolk County mainland, which is about $345,000 \mathrm{~kg} / \mathrm{yr}$. In contrast to the TN load from shallow groundwater for the SSER watershed, which annually yields about 353 kilograms per square kilometer $\left(\mathrm{kg} / \mathrm{km}^{2}\right)$, the overall TN load from Fire Island produces nitrogen at an annual rate of about $890 \mathrm{~kg} / \mathrm{km}^{2}$ - more than double the SSER loading rate from shallow groundwater.

Although high-density residential land use occupies about 8 percent of Fire Island, unsewered areas contribute about 46 percent of the overall TN load from groundwater to backbarrier estuaries. Because of the effects of wave setup and tidal pumping along the ocean shore, groundwater-protection strategies need to consider most of the island as a potential source area to the wetland and adjacent estuarine habitats within the boundaries of FIIS. TN concentrations in the park 
downgradient from at least two communities-Kismet and Robbins Rest - and from the Watch Hill leach field exceeded the natural levels observed in other undeveloped areas of FIIS by a factor of 10 or more; the presence of excess nitrogen may have important consequences for species adapted to the low nutrient levels naturally occurring in aquatic and coastal habitats of FIIS. These elevated values also indicate that recharge containing fertilizers or human waste has infiltrated the water table in upgradient areas; this water may also contain pathogens and other harmful compounds.

\section{Introduction}

Fire Island National Seashore (hereafter referred to as FIIS) occupies $42 \mathrm{~km}$ of the barrier island for which it is named that lies off the southern shore of western and central Suffolk County, Long Island, N.Y. (figs. 1 and 2). Interspersed throughout FIIS are 17 pre-existing residential beach communities that in summer months greatly increase in population through the arrival of summer residents and vacationers, and in addition, the National Park Service (NPS) has established several facilities on the island to accommodate visitors to FIIS.

Untreated wastewater from the numerous homes and businesses in the barrier-island communities generally is discharged directly into the shallow (water table) aquifer through the use of private septic systems and cesspools; wastewater from the NPS facilities also enters this aquifer through leach fields and cesspools. Contaminants entering the groundwater system can pose a threat to coastal habitats because the contaminants are transported by groundwater that discharges to coastal water bodies. In other parts of Long Island (Capone and Bautista, 1985) and elsewhere throughout coastal areas of the northeastern United States (Portnoy and others, 1998), there is concern about groundwater-derived nitrogen loading to shallow estuary systems. Excess levels of inorganic nitrogen can lead to increased production of phytoplankton and macroalgae, which in turn can lead to oxygen depletion, reductions in estuarine fish and shellfish communities, and loss of submerged seagrass habitat because of light limitation (Valiela and others, 1992).

The boundary of FIIS extends roughly $1 \mathrm{~km}$ into the back-barrier estuaries of Great South Bay, Narrow Bay, and Moriches Bay (fig. 2). Within this zone, there are extensive areas of seagrass habitat, shellfish and finfish resources, and intense recreational activity (Bokuniewicz and others, 1993). To better understand and protect the natural resources of FIIS, it is critical to determine the concentration and movement of nutrients and other contaminants being introduced into the shallow groundwater system and transported by freshwater that ultimately discharges to the surrounding coastal waters.

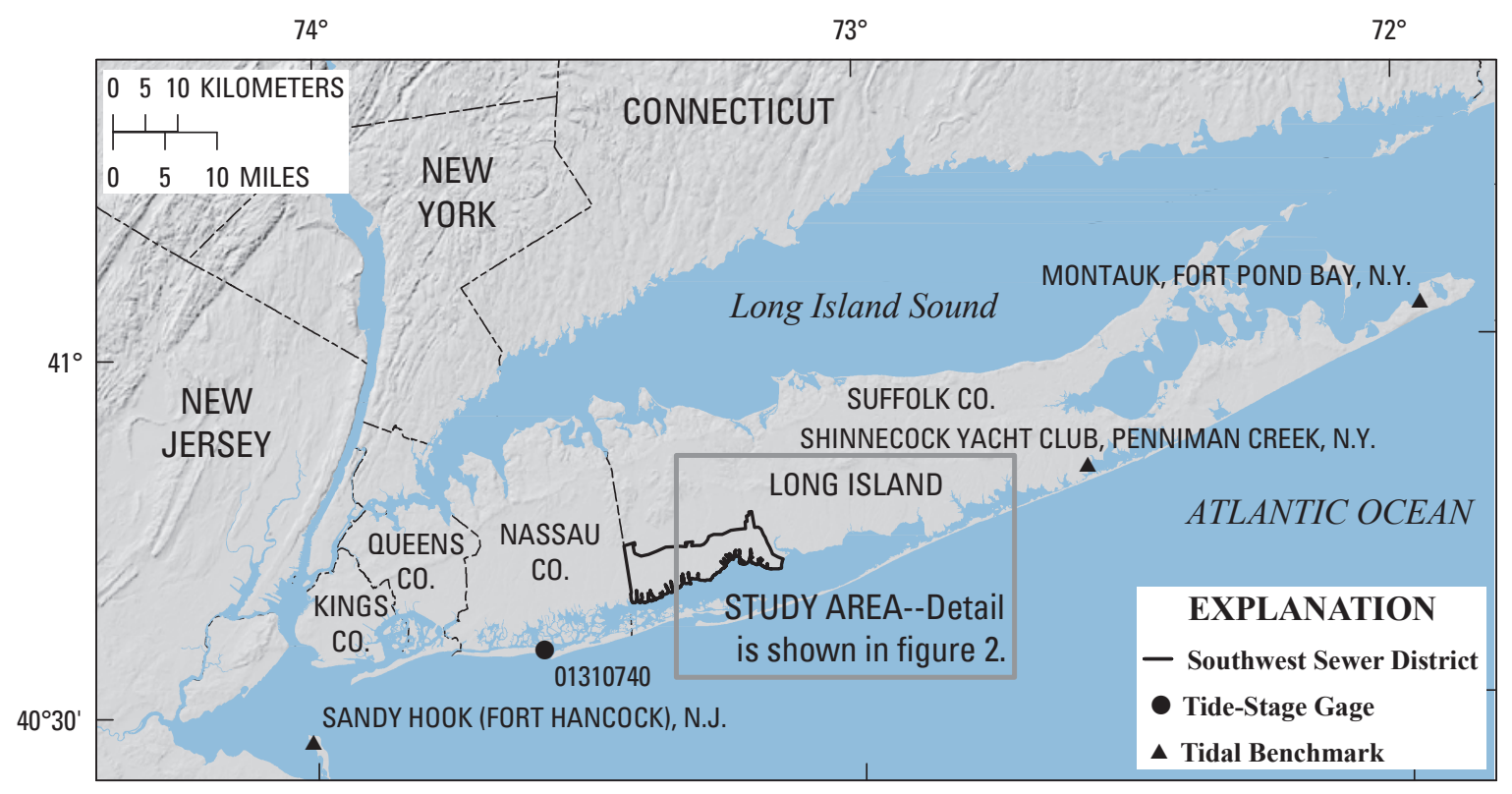

Base from The National Map,

Universal Transverse Mercator projection, NAD 83, Zone 18

Figure 1. Location of Suffolk County study area on Long Island, N.Y., tide-stage gaging station 01310740 Reynolds Channel at Point Lookout, N.Y., and selected tidal benchmarks in southeastern New York and northern New Jersey. (NAD 83, North American Datum of 1983) 


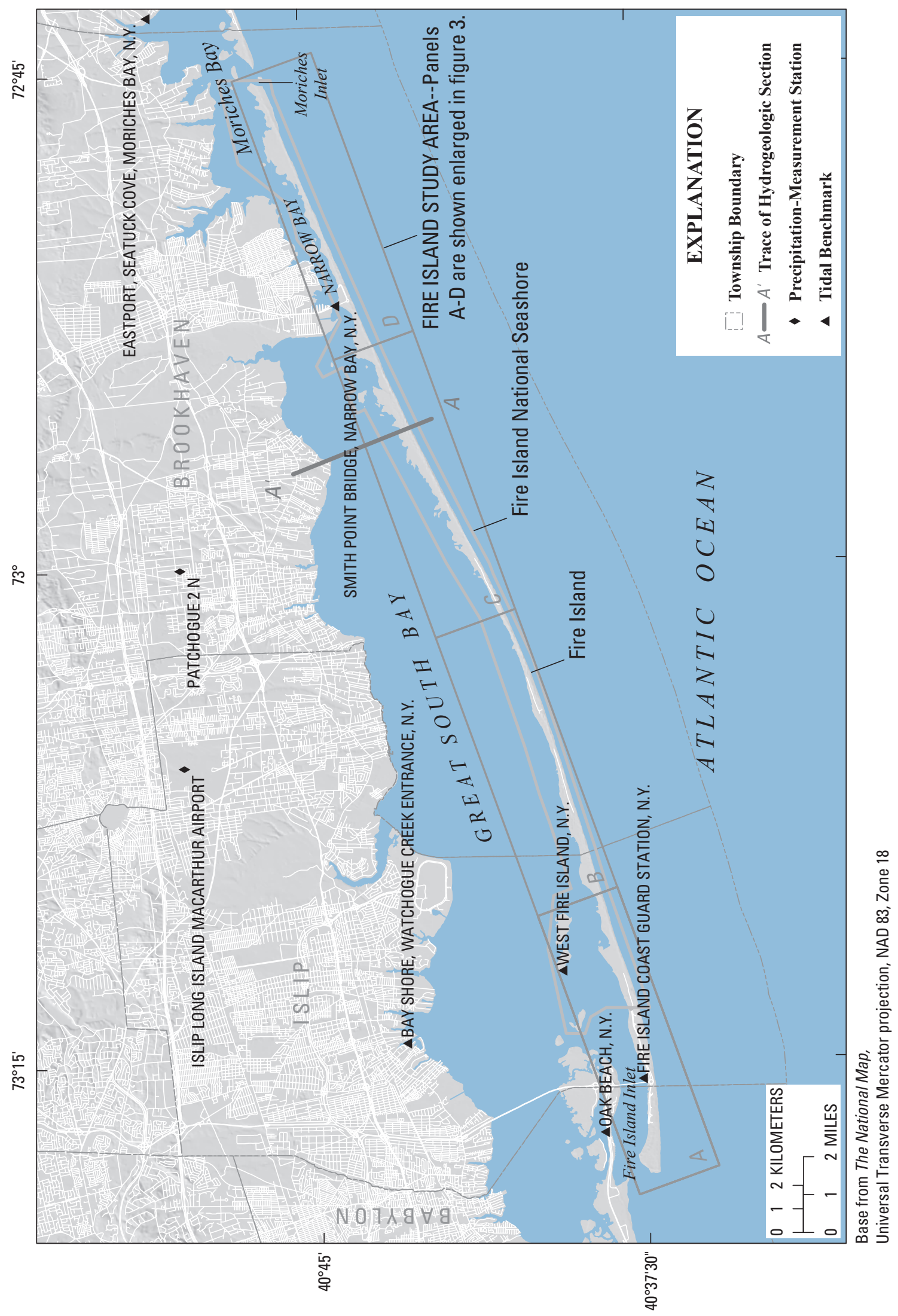

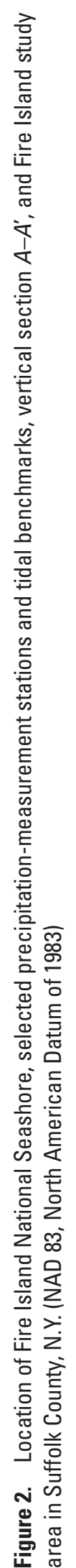


The collection of geologic and hydrologic data and the synthesis of these data into a three-dimensional groundwater flow model of the shallow aquifer system are needed to best manage the groundwater and ecological resources of FIIS.

In 2004, the U.S. Geological Survey (USGS), in cooperation with the NPS, began a 3-year investigation to (1) collect groundwater levels and water-quality samples, (2) develop a three-dimensional model of the shallow aquifer system and adjacent marine surface waters, and (3) calculate nitrogen loads in simulated groundwater discharges from the aquifer to back-barrier estuaries and the ocean. An important component of this study is an assessment of nutrient loading to the ocean and back-barrier estuaries, particularly Great South Bay. The numerical model developed as part of this investigation can be used to simulate the transport of other contaminants during subsequent studies. In addition, the network of shallow observation wells installed as part of this study can provide the foundation for a long-term monitoring program of groundwater levels and water-quality data throughout the barrier-island seashore.

\section{Purpose and Scope}

This report presents the results of data collection and analysis done as part of the 3-year investigation. Specifically, the report presents (1) the boundaries of the shallow aquifer system, (2) results of numerical simulations that show groundwater flow patterns and rates within the freshwater aquifer and adjacent saline subsurface, (3) the amount of freshwater discharge from the shallow groundwater system, (4) the quality of water in the freshwater aquifer and nutrient loads from it to coastal waters, and (5) current water use and groundwater withdrawal from the aquifer system underlying the barrier island.

\section{Methods and Approach}

The shallow aquifer system was characterized from the results of exploratory drilling, geophysical surveying, waterlevel monitoring, and water-quality sampling conducted during this study. These results were used to develop a three-dimensional model of the shallow aquifer system, from which nitrogen loads were calculated to back-barrier estuaries and the ocean. The investigation focused on four areas - the communities of Kismet and Robbins Rest, the NPS Visitor Center at Watch Hill, and the undeveloped Otis Pike Fire Island High Dune Wilderness (fig. 3).
Thirty-five observation wells were installed within FIIS to characterize subsurface hydrogeology and establish a water-table monitoring network in the four study areas. During drilling, cores were collected almost continuously at four boreholes (S126753, S126000, S125990, and S124399; figs. 4 and 5) to depths ranging from 9.8 to $15.8 \mathrm{~m}$ below land surface; additional samples were collected at variable intervals at these sites to depths between 13.4 and $41.5 \mathrm{~m}$. Filter-press samples were collected from selected cores. Geophysical logs - gamma-ray and electromagneticinduction-were collected from 26 and 21 of the newly drilled wells, respectively, including at the 4 sites where cores were collected. In addition to drilling done as part of this study, additional data regarding the hydrogeologic framework were obtained from previous investigations. These data included maps of the structure and configuration of regional hydrostratigraphic units (Smolensky and others, 1989, sheet 3; Doriski and Wilde-Katz, 1983, plates 7 and 8), as well as data from boreholes and wells that were published previously or are on file at the USGS Water Science Center office in Coram, N.Y.

The hydrologic setting was characterized from (1) filterpress samples and borehole electromagnetic-induction logs, (2) water-level monitoring and water-quality sampling, and (3) previous investigations of the Fire Island aquifer system and barrier-island aquifer systems elsewhere. Gamma-ray and electromagnetic-induction logs, filter-press samples, generalized descriptions of geologic cores, and corresponding hydrogeologic units for borings at four wells (S126753, S126000, S125990, and S124399; locations are shown in fig. 4) are shown in figure 5.

\section{Fire Island Study Area}

Fire Island is approximately $60 \mathrm{~km}$ long and $0.5 \mathrm{~km}$ wide and is bounded by the Great South Bay, Narrow Bay, and Moriches Bay estuaries to the north; the Atlantic Ocean to the south; and Fire Island Inlet and Moriches Inlet to the west and east, respectively (fig. 2). The $181 \mathrm{~km}^{2}$ Fire Island study area encompasses the entire barrier island, which lies within parts of the towns of Babylon, Islip, and Brookhaven and includes most of the adjacent marine surface waters within the boundaries of FIIS (fig. 2).

\section{Population and Land Use}

The 17 residential communities within FIIS contain over 4,100 homes, and although they have a permanent resident 
population of only about 400 , the summer residency climbs to over 20,000 (National Park Service, 2003). About 2.2 million people are estimated to annually visit 1 of the 17 communities, Smith Point County Park (fig. 3), the waterways surrounding Fire Island, or a FIIS facility (National Park Service, 2007a). Combined visitation on a peak-season weekend day can be as high as 100,000 (National Park Service, 2002).

Land-use analyses done by the Suffolk County Department of Planning (SCDP) for the three townships (Babylon, Islip, and Brookhaven, fig. 2) that encompass parts of Fire Island indicated only about 3 percent of the land area (omitting surface waters) was vacant (Carl Lind, Suffolk County Department of Planning, written commun., 2006). About 81 percent of the land area is recreational and open space, including a portion of the island stretching from just west of Smith Point County Park to just east of the NPS Visitor Center at Watch Hill (fig. 3) that Congress designated as a National Wilderness Area in 1980. About 12 percent of the land area is residential, although most residences are occupied only during summer months (National Park Service, 2003). About 8 percent of the land area is classified as highdensity residential with at least five dwelling units per acre, 4 percent is medium density (between one and five dwelling units per acre), and less than 1 percent is low density (one dwelling unit per acre or less). The approximately 3 percent of the land area remaining is distributed among six other land uses - commercial, industrial, institutional, transportation, utilities, and waste handling and management.

\section{Water Use}

The public water supply for the barrier-island communities and all NPS, State, and county park facilities is derived solely from wells that pump groundwater from the underlying aquifer system; a small fraction of this pumpage occurs on the Long Island mainland. Virtually all water supply currently is withdrawn from the uppermost Late Cretaceous (Magothy) aquifer, because freshwater in the overlying Pleistocene (upper glacial) aquifer and Holocene (recent) deposits is limited to a shallow lens. Historically, the shallow freshwater lens was used to supply summer residences; however, this supply has largely been abandoned because of elevated levels of chloride, nitrate, and coliform bacteria (Leggette, Brashears \& Graham, Inc., 1996). The shallow freshwater lens is not in hydraulic connection with the regional aquifer system.

Currently (2005), Fire Island is served by 10 public water-supply systems (fig. 6). The service-area locations for the Kismet, Fair Harbor-Summer Club, Point O'Woods-Fire
Island Pines, Davis Park, and Westhampton distribution zones of the Suffolk County Water Authority (SCWA) are based on a geographic information system (GIS) spatial data set assembled by the SCWA (Jeff Altorfer, Suffolk County Water Authority, written commun., 2005). Service-area locations for the water-supply systems operated by the communities of Saltaire, Ocean Beach, Seaview, and Ocean Bay Park were digitized from distribution-system maps on file at the Suffolk County Department of Health Services (SCDHS). The locations of buildings within Robert Moses State Park were digitized and used in this study to estimate the service-area location for this park's water-supply system.

Monthly pumpage in 2005 (table 1) was compiled for the four distribution zones of the SCWA that withdraw groundwater from the aquifer system underlying Fire Island (Mike Boufis, Suffolk County Water Authority, written commun., 2006) and for the water-supply system at Robert Moses State Park (Amy Cooper on behalf of Elizabeth Wintenberger, New York State Office of Parks, Recreation and Historic Preservation, written commun., 2007). Monthly withdrawals in 2005 also were compiled for the community water-supply systems in Saltaire, Ocean Beach, Seaview, and Ocean Bay Park from pumpage records on file at the SCDHS. Quarterly meter readings in 2005 were compiled for the SCWA Westhampton distribution zone, which distributes water supply to the NPS Wilderness Visitor Center and to Smith Point County Park (figs. 3 and 6), but does not withdraw from the underlying aquifer system (Mike Boufis, Suffolk County Water Authority, written commun., 2006).

Most public-supply water on Fire Island is ultimately returned to the water table, primarily through on-site wastewater disposal systems and, to a lesser extent, as leakage from the water-distribution system; the remainder is lost as consumptive use. In unsewered areas of Long Island, the return flow of public-supply water to the water table is estimated to be about 85 percent of total public-supply pumpage - approximately 70 percent through wastewater disposal systems and 15 percent via leaky transmission systems (Franke and McClymonds, 1972). A small number of private and NPS dwellings not served by the public water-supply systems derive drinking water individually or collectively from single- or multiple-well systems. Information on the amount of drinking water derived from these wells typically is unavailable, however, because the pumping rates commonly are less than the New York State Department of Environmental Conservation required permitting and reporting level of $2.8 \mathrm{~L} / \mathrm{s}$. 

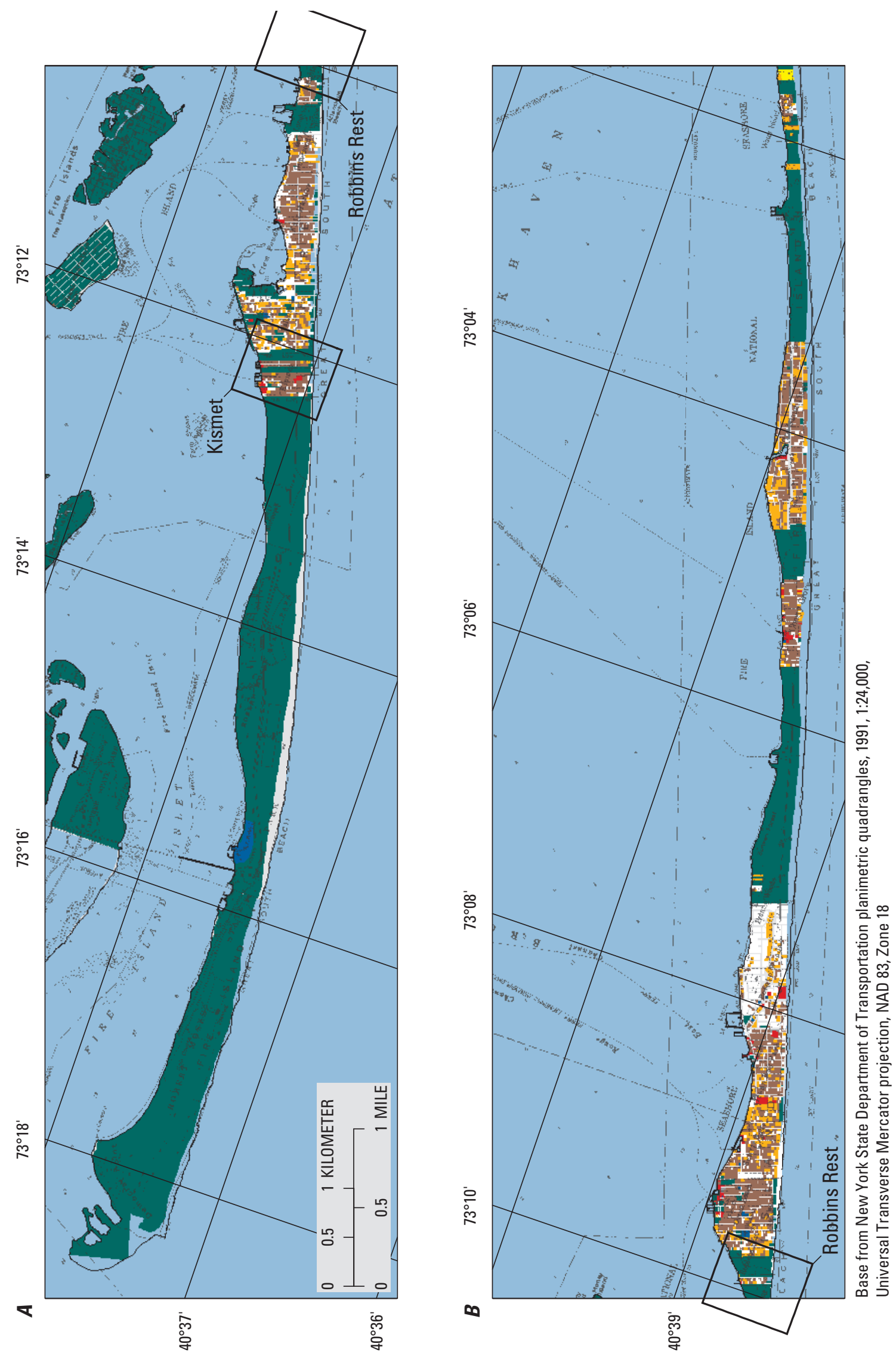

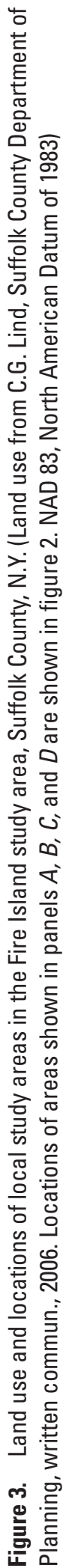



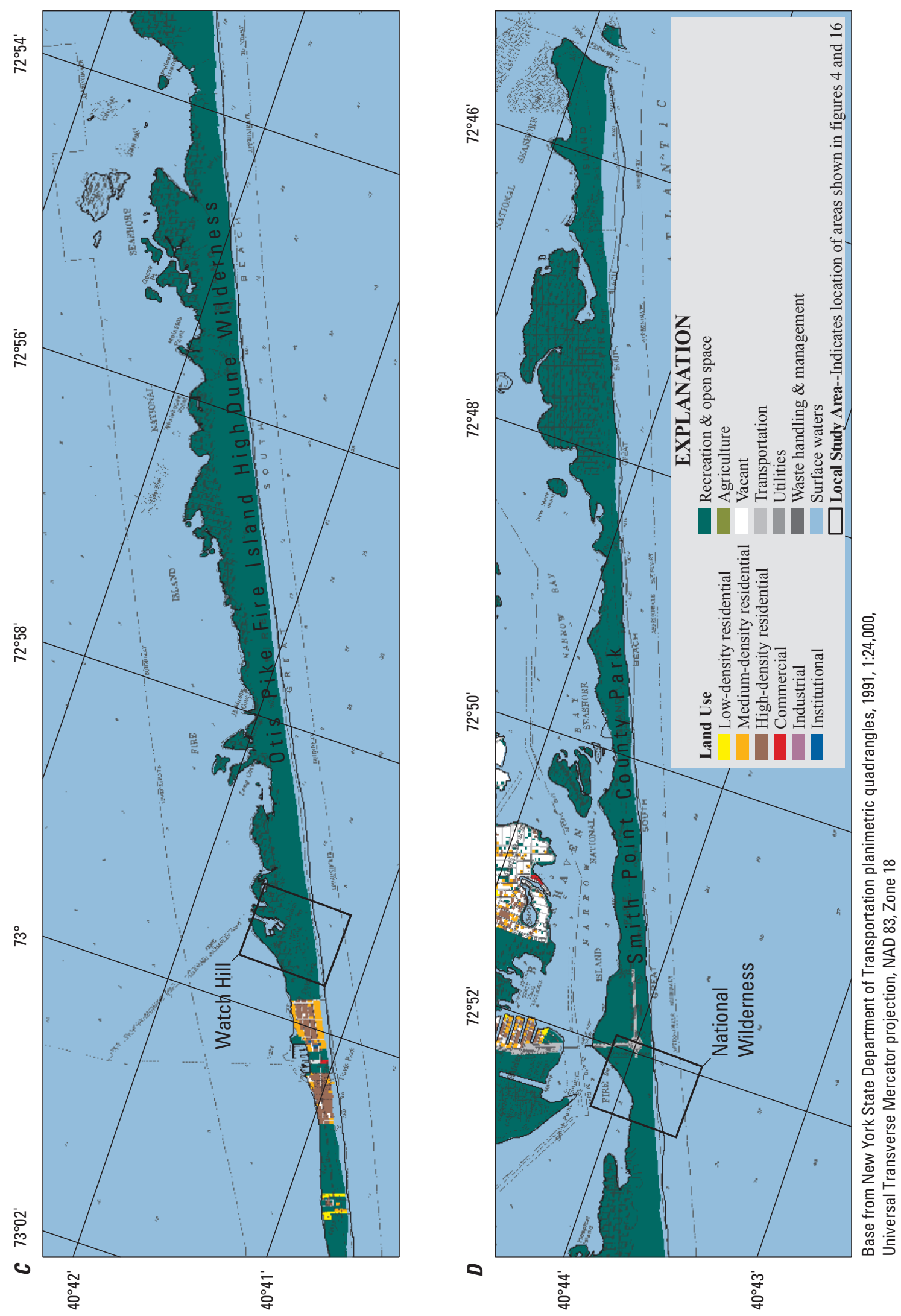

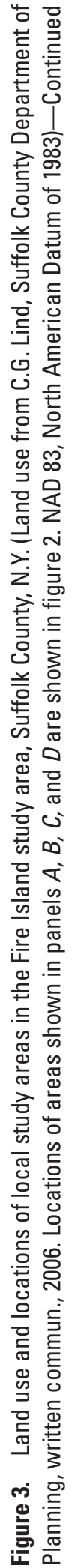




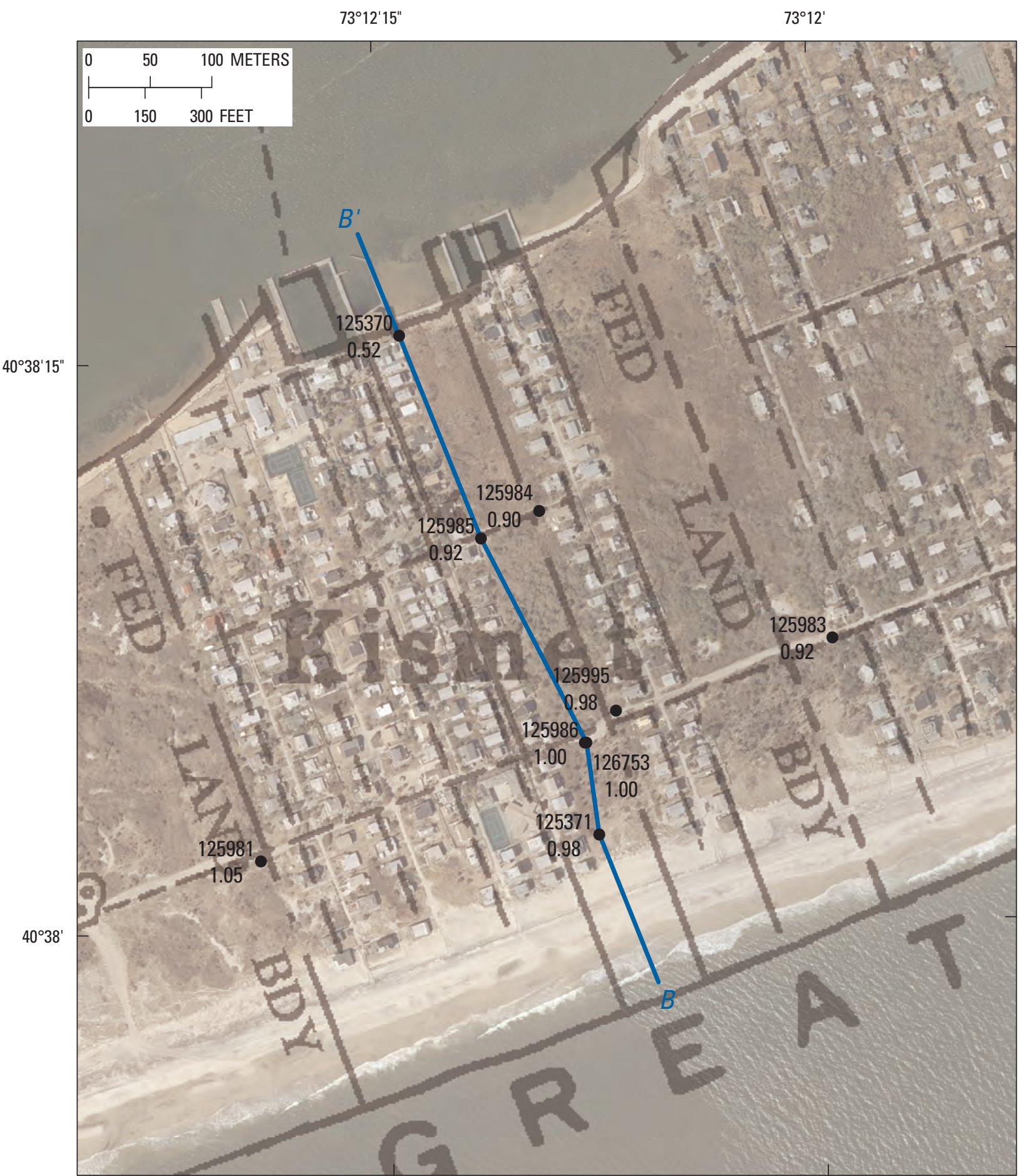

Base from New York State Department of Transportation planimetric quadrangles, 1991, 1:24,000; Universal Transverse Mercator projection, NAD 83, Zone 18

\section{EXPLANATION}

$B-B^{\prime}$ Trace of Hydrogeologic Section--Shows location of vertical section shown in figure 8 A.

${ }_{0.52}^{125370}$ Observation Well--Upper number is identifier. Lower number is water level, in meters above NGVD 29.

Figure 4. Locations of observation wells and vertical sections $B-B^{\prime}$ through $E-E$ in local study areas and groundwater levels during October 31-November 1, 2005, on Fire Island, Suffolk County, N.Y. (Well number is assigned by New York State Department of Environmental Conservation. Prefix "S" denoting Suffolk County is omitted. NGVD 29, National Geodetic Vertical Datum of 1929) 


\begin{tabular}{|ccc}
\hline 0 & 50 & 100 METERS \\
& $\mid$ & 1 \\
0 & 150 & 300 FEET
\end{tabular}

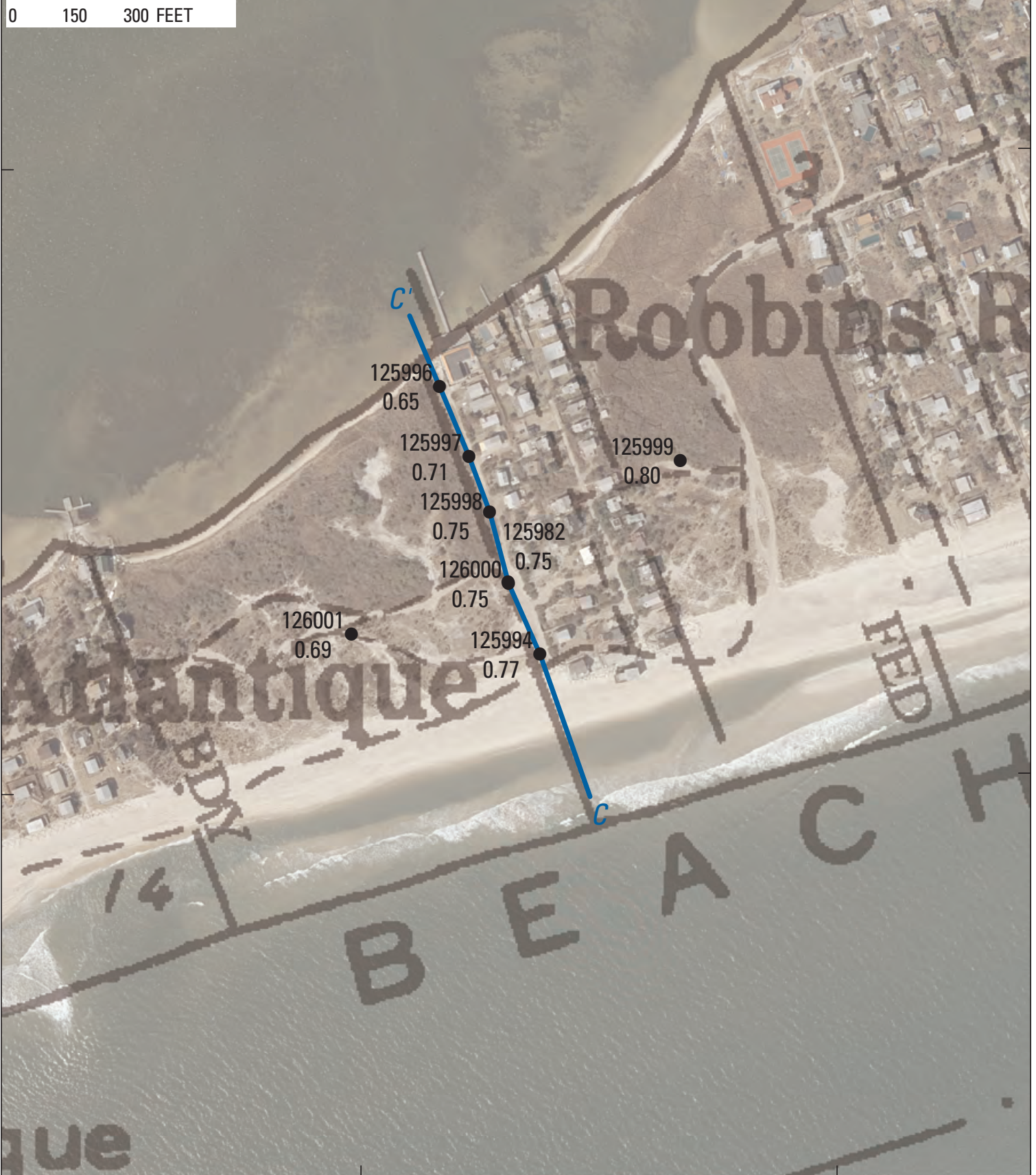

Base from New York State Department of Transportation planimetric quadrangles, 1991, 1:24,000; Universal Transverse Mercator projection, NAD 83, Zone 18

\section{EXPLANATION}

$C-C^{\prime}$ Trace of Hydrogeologic Section--Shows location of vertical section shown in figure 8B.

${ }_{0.65}^{125996}$ Observation Well--Upper number is identifier. Lower number is water level, in meters above NGVD 29.

Figure 4. Locations of observation wells and vertical sections $B-B^{\prime}$ through $E-E$ in local study areas and groundwater levels during October 31-November 1, 2005, on Fire Island, Suffolk County, N.Y. (Well number is assigned by New York State Department of Environmental Conservation. Prefix "S" denoting Suffolk County is omitted. NGVD 29, National Geodetic Vertical Datum of 1929)—Continued 


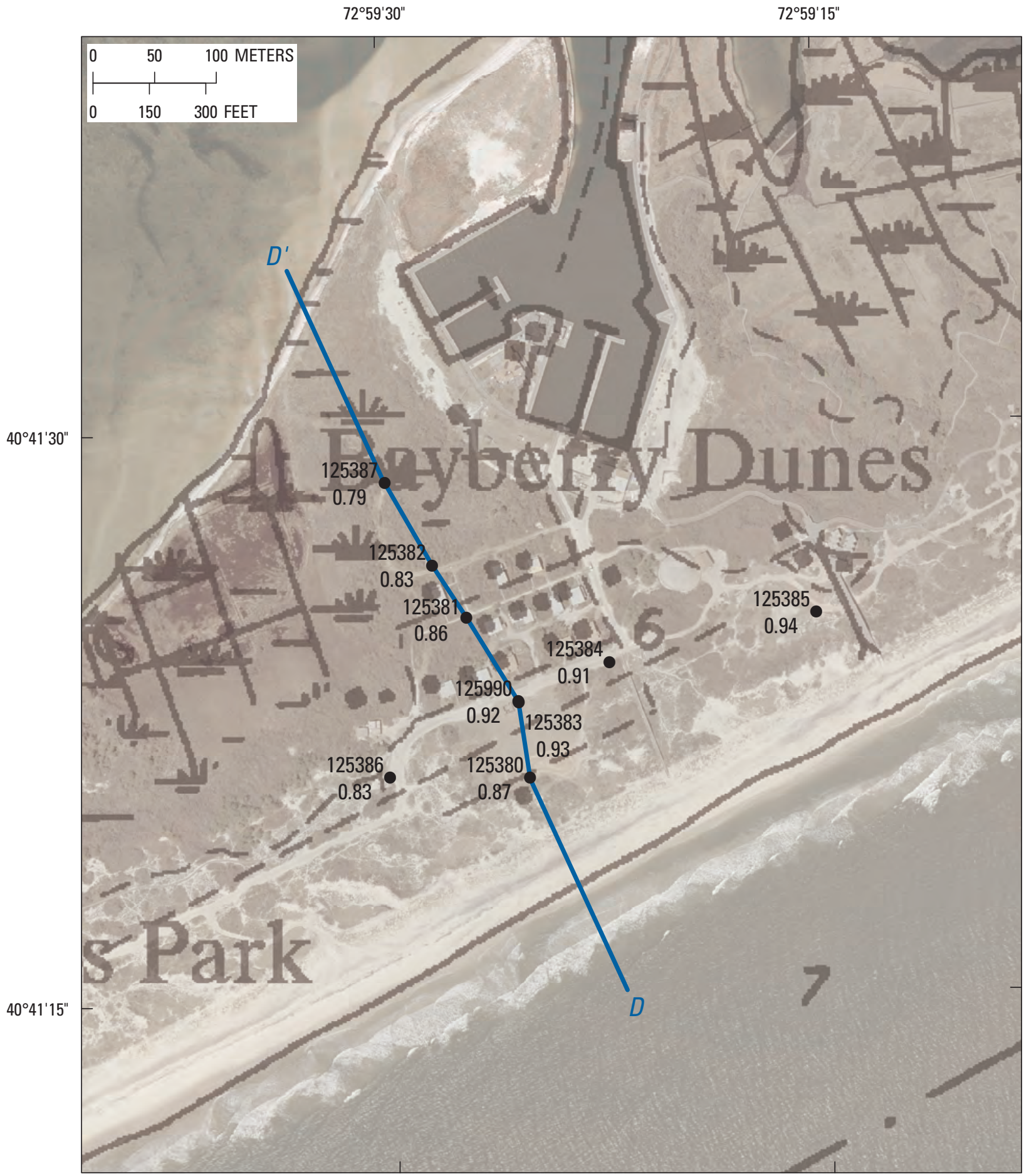

Base from New York State Department of Transportation planimetric quadrangles, 1991, 1:24,000; Universal Transverse Mercator projection, NAD 83, Zone 18

\section{EXPLANATION}

$D-D^{\prime}$ Trace of Hydrogeologic Section--Shows location of vertical section shown in figure 8C.

0.79 Observation Well--Upper number is identifier. Lower number is water level, in meters above NGVD 29.

Figure 4. Locations of observation wells and vertical sections $B-B^{\prime}$ through $E-E$ in local study areas and groundwater levels during October 31-November 1, 2005, on Fire Island, Suffolk County, N.Y. (Well number is assigned by New York State Department of Environmental Conservation. Prefix "S" denoting Suffolk County is omitted. NGVD 29, National Geodetic Vertical Datum of 1929)-Continued 


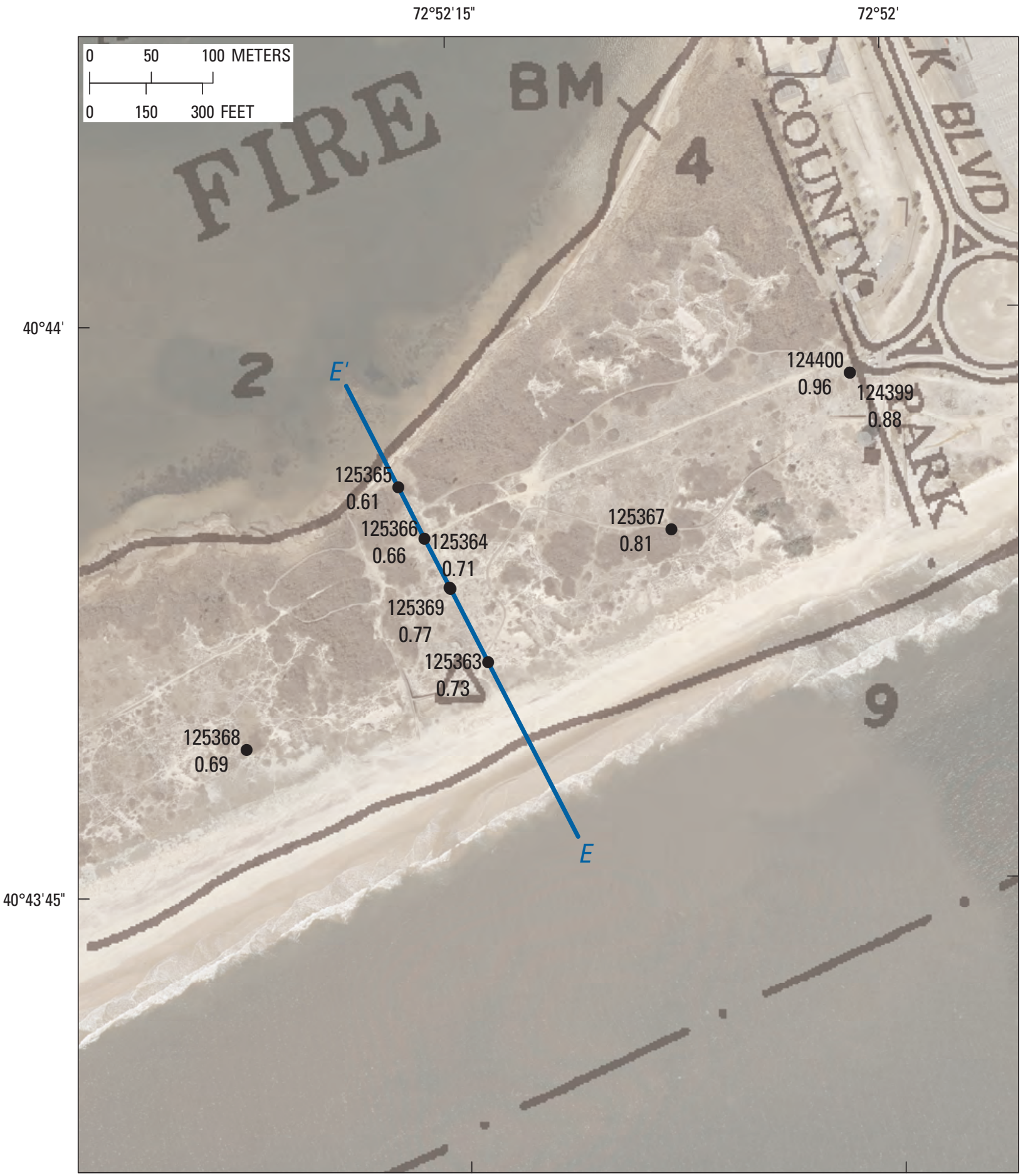

Base from New York State Department of Transportation planimetric quadrangles, 1991, 1:24,000; Universal Transverse Mercator projection, NAD 83, Zone 18

\section{EXPLANATION}

$E-E^{\prime}$ Trace of Hydrogeologic Section--Shows location of vertical section shown in figure 8D.

0.96 - Observation Well--Upper number is identifier. Lower number is water level, in meters above NGVD 29.

Figure 4. Locations of observation wells and vertical sections $B-B^{\prime}$ through $E-E$ in local study areas and groundwater levels during October 31-November 1, 2005, on Fire Island, Suffolk County, N.Y. (Well number is assigned by New York State Department of Environmental Conservation. Prefix "S" denoting Suffolk County is omitted. NGVD 29, National Geodetic Vertical Datum of 1929)—Continued 

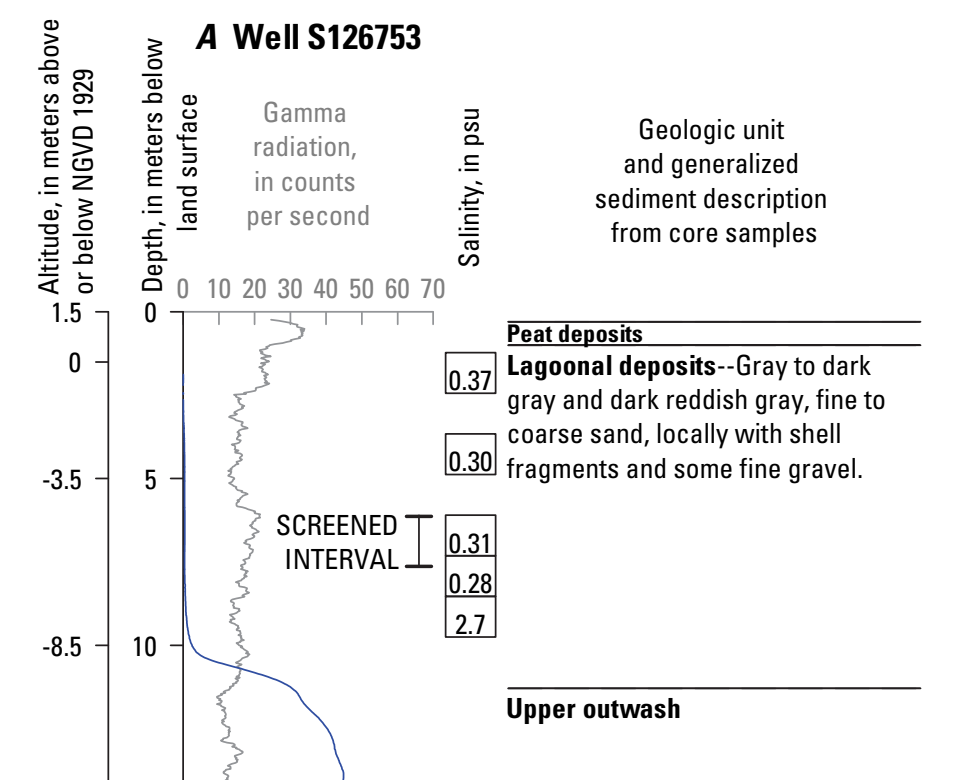

$-13.5$
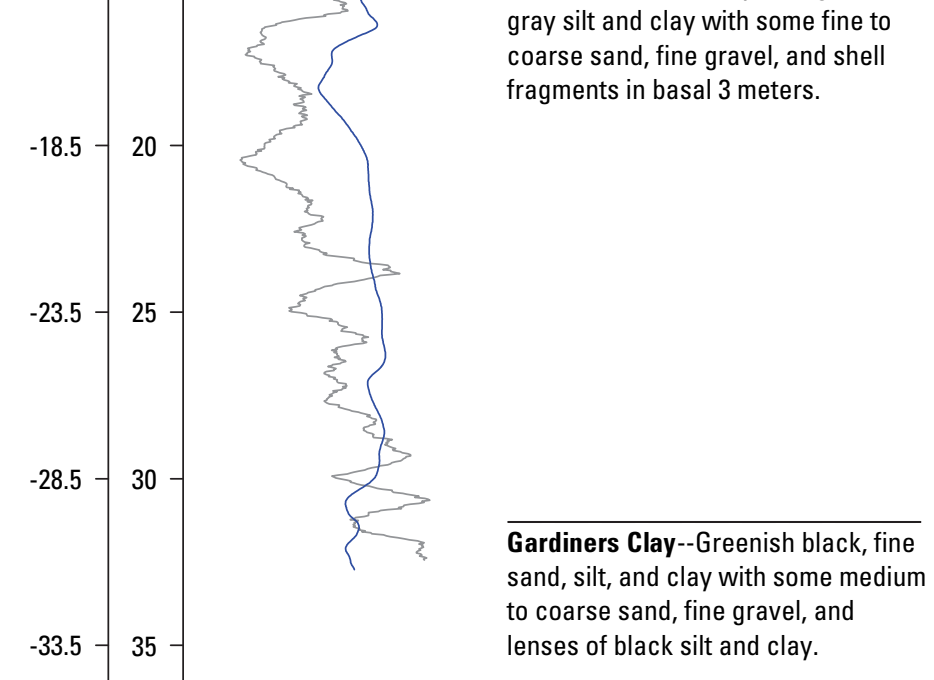

$\begin{array}{rrrrr}0 & 300 & 600 & 900 & 1,200\end{array}$

Electromagnetic induction, in millisiemens per meter
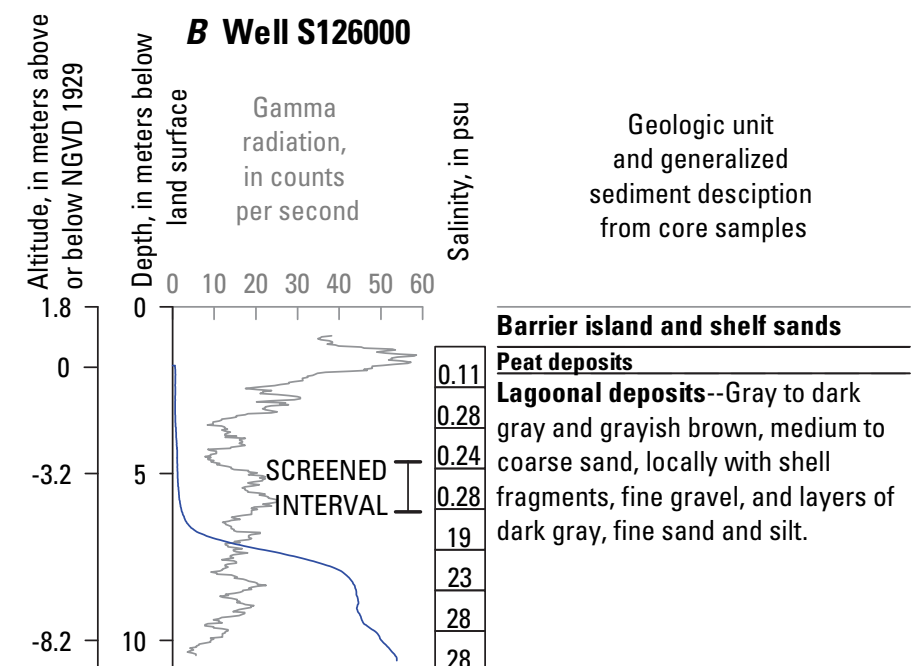


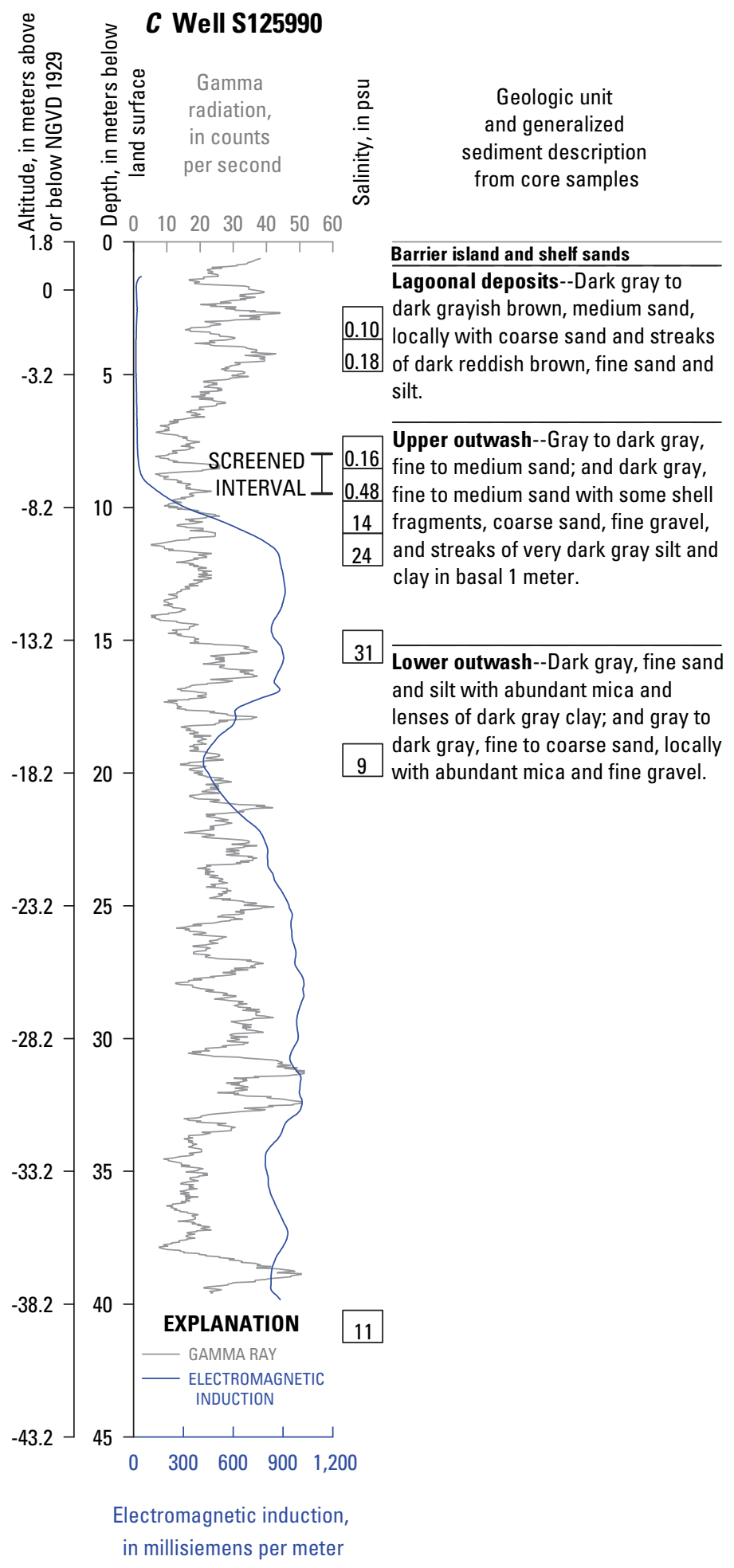

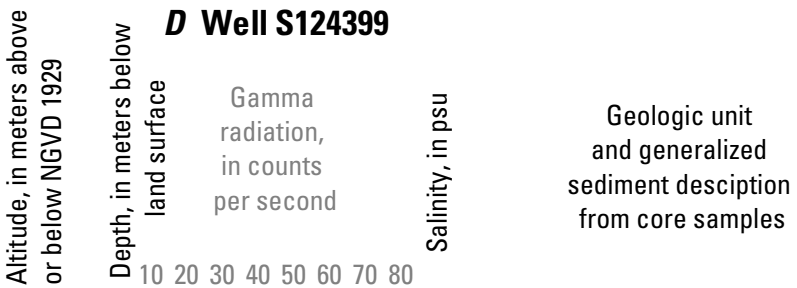

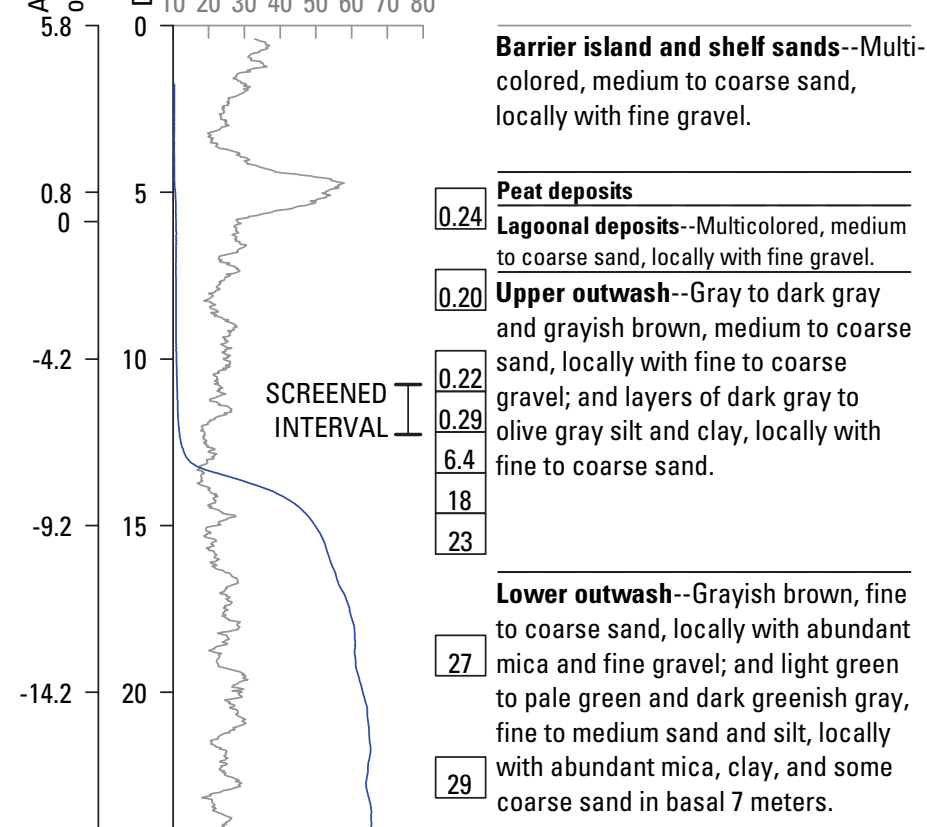

$-19.2-$

25

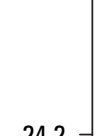

$-24.2$

30

$-29.2$

$-34.2$

35
40
45

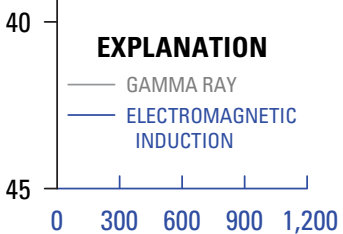

Gardiners Clay--Dark greenish gray to olive gray and brown silt and clay with some mica.

Electromagnetic induction, in millisiemens per meter

Figure 5. Gamma-ray and electromagnetic-induction logs, salinity from filter-press core samples, generalized sediment description from core samples, and corresponding geologic units for borings at four wells on Fire Island, Suffolk County, N.Y., (A) well 126753, (B) well 126000, (C) well 125990, and (D) well 124399. (Well locations are shown in figure 4. NGVD 29, National Geodetic Vertical Datum of 1929; psu, practical salinity units at 25 degrees Celsius)—Continued 

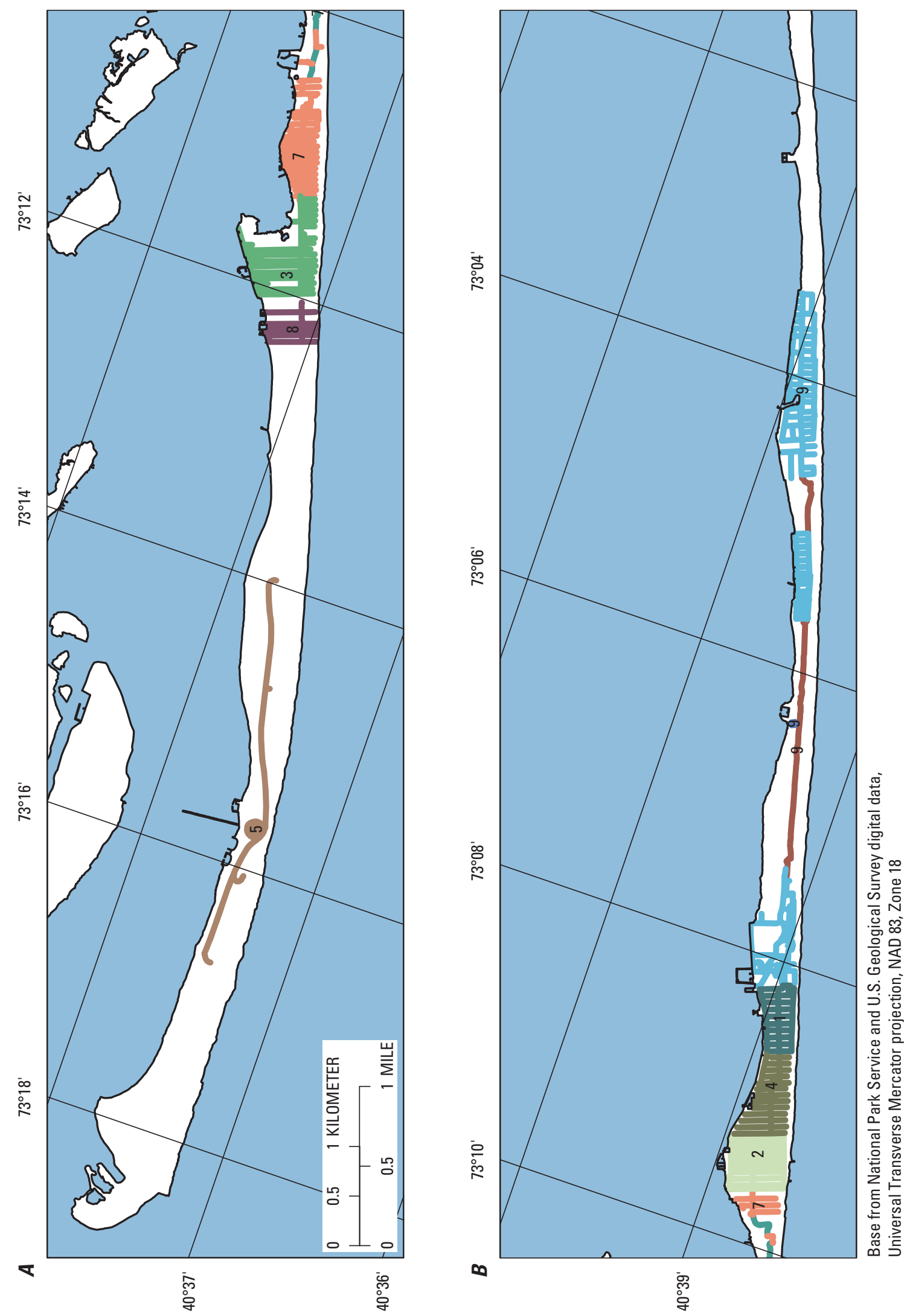

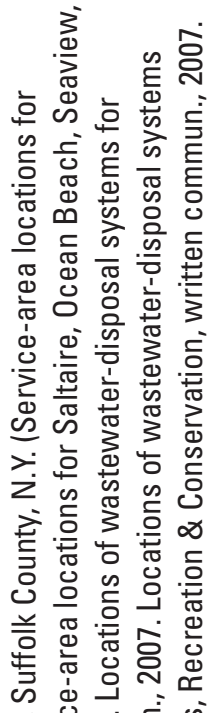

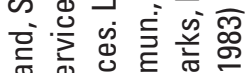
西 ळ

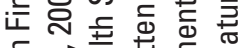
ธᄃ

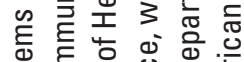
总 के वे बे है त

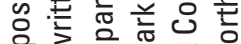
Q $0 \geq z$ 产焉元 홍을 을 以

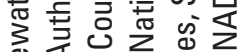

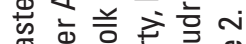

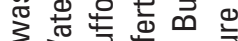

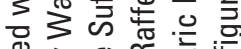

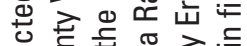
过 吉

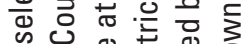
음 흠 응 응 ๙

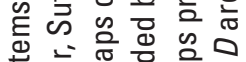

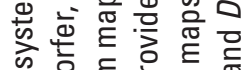
के

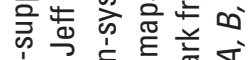

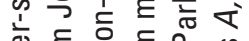
离

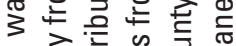

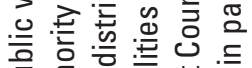

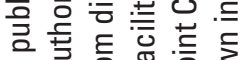

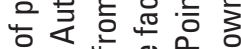

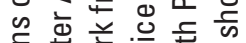
을 䎡 त्र U ते

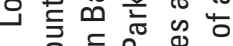

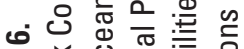
님응 흥 음

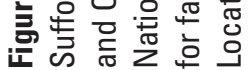



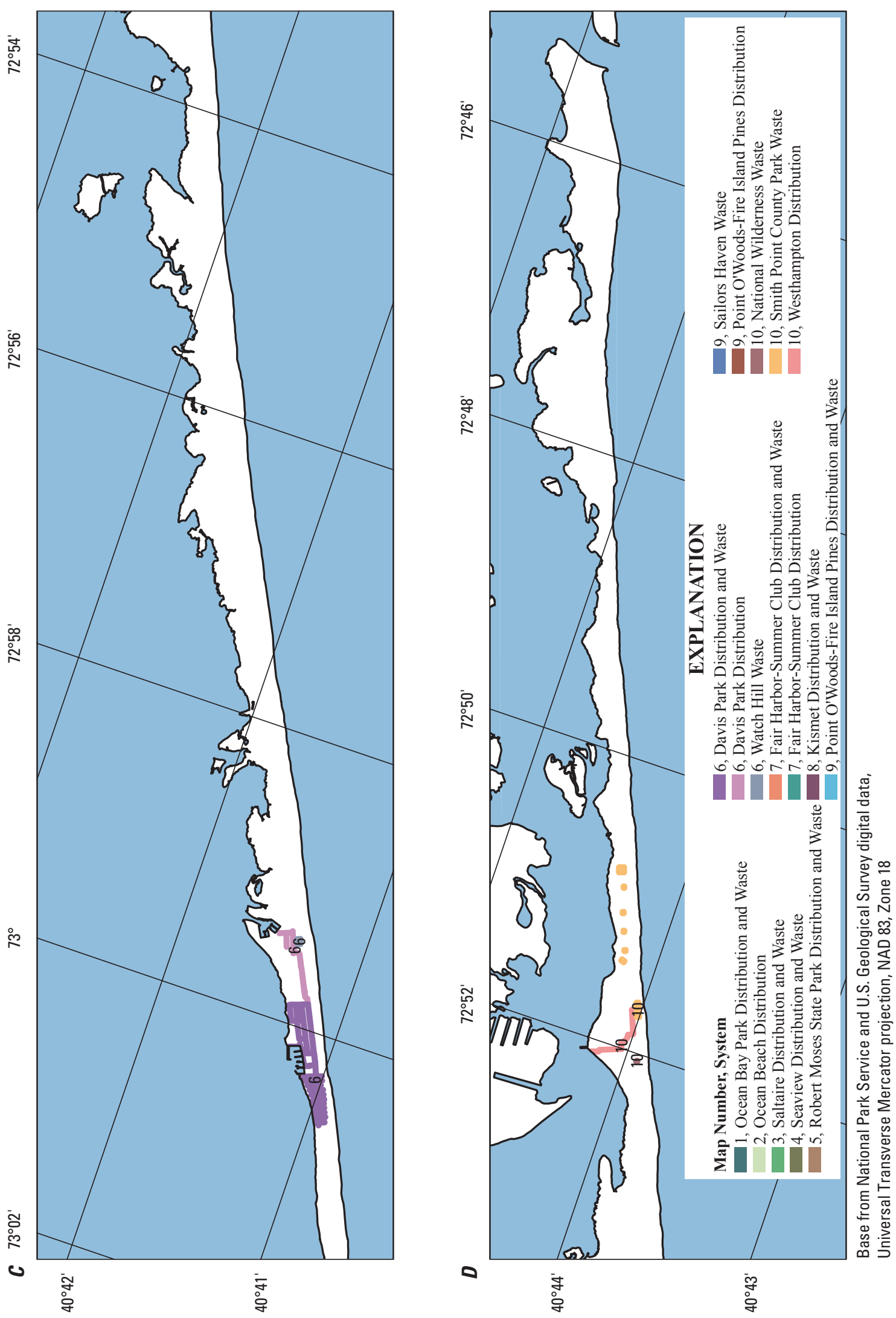

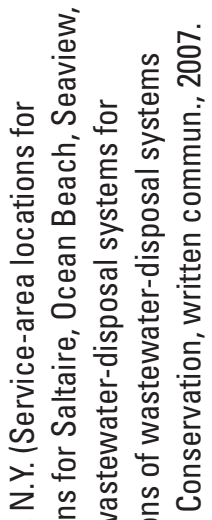
촏은 3 응

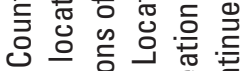

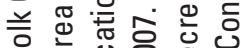

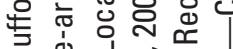
क .

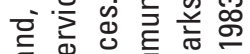

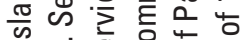

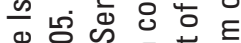

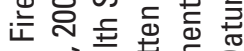
ธᄃ் ฮั

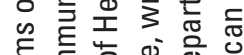
है ह 苾

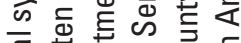

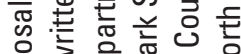

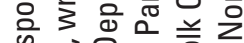

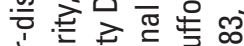

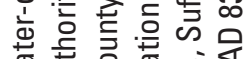

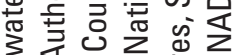
过立言京

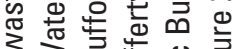

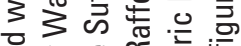
ఖ

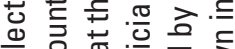

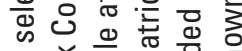

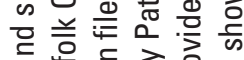
ธิ

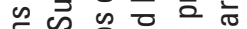
ह

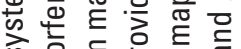
के 흥 ह

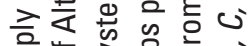
言告 क⿱ 口) कि ऽ ह స 홍 음 듬 문

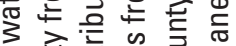

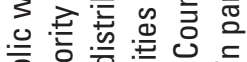

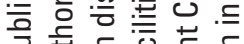
흔휴 휸

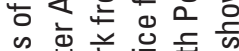

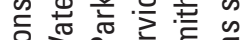
을 잏

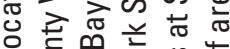

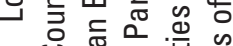

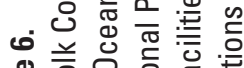

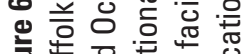

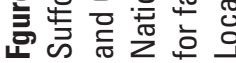




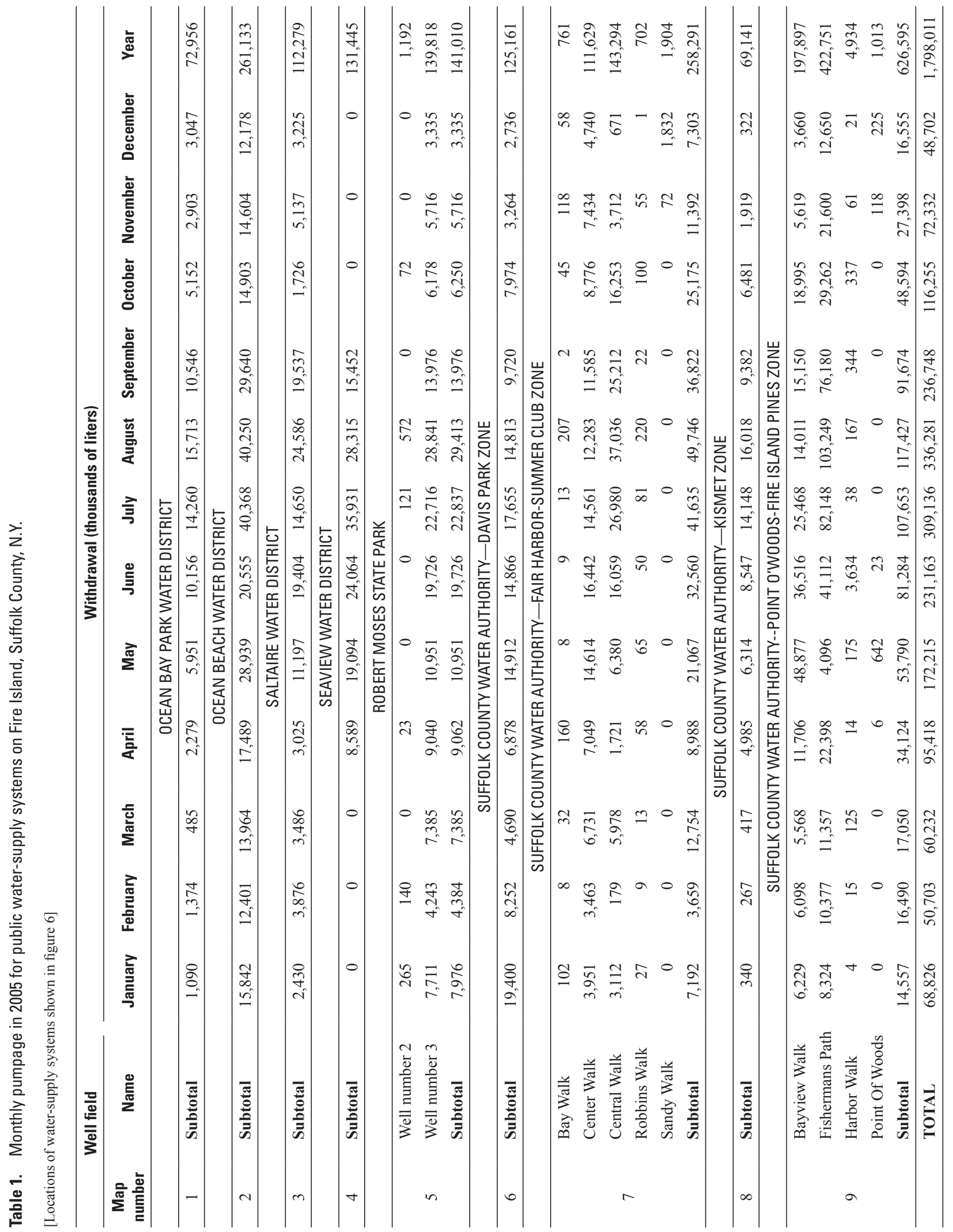




\section{Hydrogeologic Framework}

The fresh groundwater reservoir on Fire Island consists of a freshwater flow system within a sequence of Holocene surficial deposits and Pleistocene glacial and nonglacial deposits that are underlain by Late Cretaceous Coastal Plain deposits.

\section{Geologic Setting}

Fire Island is underlain by a complex aquifer system consisting of unconsolidated glacial, lacustrine, deltaic, and marine deposits of clay, silt, sand, and gravel that range in age from Late Cretaceous to Holocene. These deposits overlie a southward-sloping basement complex of crystalline bedrock of Precambrian and (or) Paleozoic age. A generalized description of the uppermost Cretaceous, Pleistocene, and Holocene geologic units and their relation to hydrogeologic units is provided in table 2; the underlying Cretaceous units are omitted because they are hydraulically isolated from the shallow aquifer system by the low permeability of intervening units (Scorca and others, 1995) and, therefore, were not considered in this investigation. A generalized vertical section depicting the geometry of hydrogeologic units underlying Fire Island is presented in figure 7.

\section{Monmouth Group}

The uppermost unit of Cretaceous deposits on Long Island is the Monmouth Group, which constitutes the Monmouth greensand and unconformably overlies the Matawan Group and Magothy Formation, undifferentiated (Magothy aquifer). In Suffolk County, the Monmouth greensand consists primarily of interbedded marine deposits of greenish to black clay, silt, and sand containing large amounts of glauconite and lignite (Jensen and Soren, 1974). The unit does not appear to have been reached by any borings drilled during this study (fig. 8).

\section{Pleistocene Deposits}

Pleistocene deposits unconformably overlie Cretaceous deposits in the Fire Island study area and consist of the Gardiners Clay and overlying Wisconsinan deposits. The coarser-grained (mainly sand and gravel) Wisconsinan deposits are considered collectively as the upper glacial aquifer.

Table 2. Generalized description of geologic and hydrogeologic units in the Fire Island study area, Suffolk County, N.Y.

[Descriptions of Upper Cretaceous deposits modified from Jensen and Soren (1974). Descriptions of selected Pleistocene deposits modified from Jensen and Soren (1974) and Doriski and Wilde-Katz (1983). Descriptions of selected Holocene deposits modified from Jones and Schubel (1980) and LoCicero (2006)]

\begin{tabular}{|c|c|c|c|}
\hline Age & Geologic unit & Hydrogeologic unit & Generalized description of deposits \\
\hline \multirow[t]{4}{*}{ Holocene } & \multicolumn{2}{|c|}{ Barrier island and shelf sands } & Fine to medium sand. \\
\hline & \multicolumn{2}{|c|}{ Peat deposits } & Black peat with some medium to fine sand. \\
\hline & \multicolumn{2}{|c|}{ Seagrass beds } & $\begin{array}{l}\text { Inorganic sediments consist mostly of fine sand and silt with } \\
\text { some medium sand. }\end{array}$ \\
\hline & \multicolumn{2}{|c|}{ Estuarine mud } & Clay and silt with some fine sand. \\
\hline \multirow[t]{3}{*}{ Pleistocene } & Upper outwash & Upper glacial aquifer ${ }^{1}$ & $\begin{array}{l}\text { Brown, fine to coarse sand, locally with some gravel and } \\
\text { streaks of silt and clay. }\end{array}$ \\
\hline & \multicolumn{2}{|c|}{ "20-foot" clay } & $\begin{array}{l}\text { Grayish-green to gray clay that contains a few sand and silt } \\
\text { beds, and has same fossil content as Gardiners Clay }\end{array}$ \\
\hline & \multicolumn{2}{|c|}{ Gardiners Clay } & $\begin{array}{l}\text { Greenish-gray to gray clay and silt with some interbedded } \\
\text { sand and gravel. Locally contains diatoms, foraminifera, } \\
\text { shell fragments of pelecypods and gastropods, and peat. }\end{array}$ \\
\hline Upper Cretaceous & Monmouth Group & Monmouth greensand & $\begin{array}{l}\text { Greenish to black clay, silt, and sand containing large } \\
\text { amounts of glauconite and lignite. }\end{array}$ \\
\hline
\end{tabular}

${ }^{1}$ Coarse-grained deposits of post-Cretaceous age on Long Island are commonly considered one hydrologic unit and are referred to as the upper glacial aquifer. (See discussion in text.) 


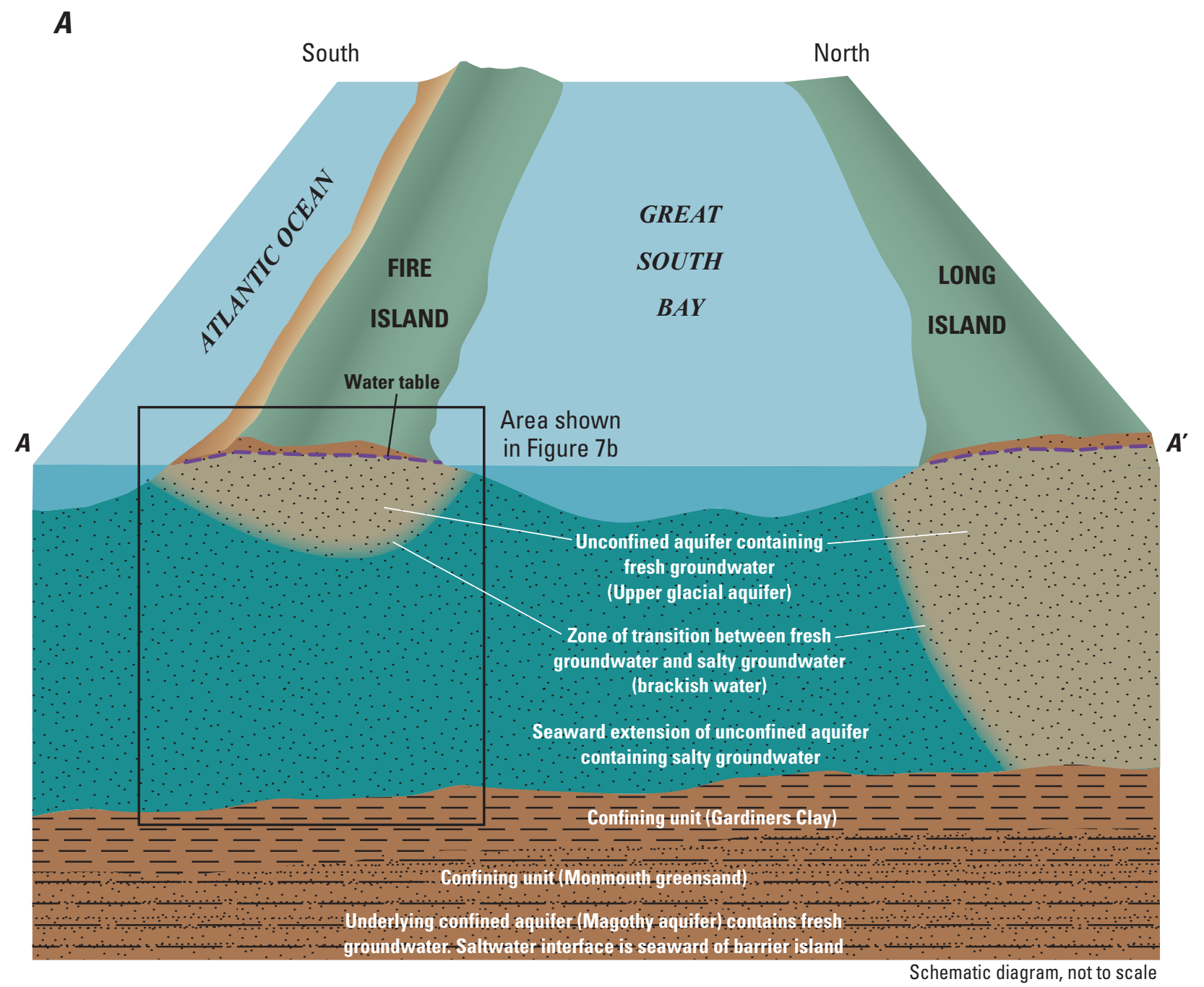

Figure 7. Generalized vertical section $A-A^{\prime}$ showing major hydrogeologic units and approximate distribution and flow directions of fresh and saline groundwater along $(A)$ the southern shore of Long Island and $(B)$ on Fire Island, N.Y. $[(A)$ modified from Scorca and others, 1995 figure 2; $(B)$ modified from Collier, 2006, figure 3. General location of section is shown in figure 2.]

\section{Gardiners Clay}

The lowermost unit of Pleistocene deposits beneath Fire Island is the Gardiners Clay. This unit generally is present throughout most of the study area (fig. 9), except along part of the southern shore of the Long Island mainland. In Suffolk County, the Gardiners Clay consists primarily of marine deposits of greenish-gray to gray clay and silt with some interbedded sand and gravel (Jensen and Soren, 1974). In southern Nassau and southwestern Suffolk Counties, the unit also contains diatoms, foraminifera, shell fragments of pelecypods and gastropods, and peat (Doriski and WildeKatz, 1983). Two borings drilled during this study reached the Gardiners Clay (S126753 and S124399, figs. 5 and 8), although neither boring penetrated its full thickness.

\section{Wisconsinan Deposits}

Late Pleistocene deposits in southern Nassau and southwestern Suffolk Counties are separated into three units by Doriski and Wilde-Katz (1983). These units are, in ascending order, a lower unit of Late Pleistocene outwash (hereafter referred to as the lower outwash), the "20-foot" clay, and an upper unit of Late Pleistocene outwash (hereafter referred to as the upper outwash). 


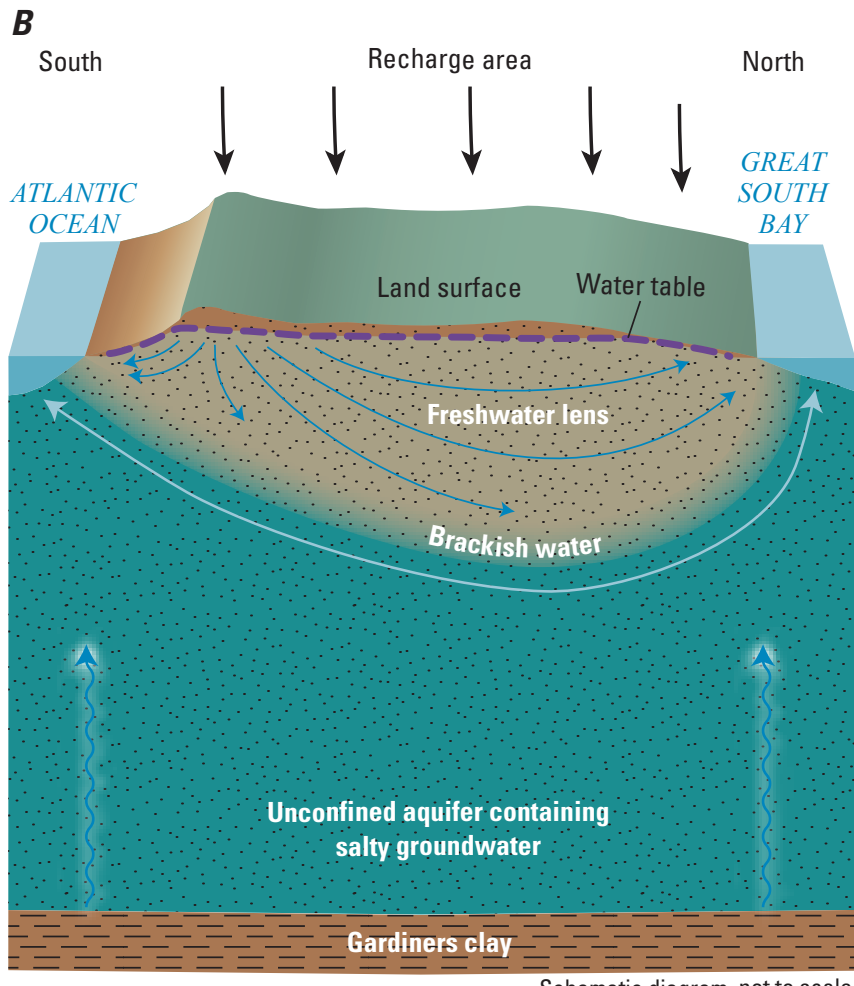

Schematic diagram, not to scale

Figure 7. Generalized vertical section $A-A^{\prime}$ showing major hydrogeologic units and approximate distribution and flow directions of fresh and saline groundwater along $(A)$ the southern shore of Long Island and $(B)$ on Fire Island, N.Y. [(A) modified from Scorca and others, 1995 figure 2;

$(B)$ modified from Collier, 2006, figure 3. General location of section is shown in figure 2.] - Continued

\section{Lower Outwash}

The lower outwash constitutes the lowermost unit of the upper glacial aquifer. The lower outwash consists primarily of light brown, fine to medium sand (Doriski and WildeKatz, 1983), which in the study area commonly contains silt; the basal 6 to $9 \mathrm{~m}$ generally consist of silt and clay with some fine to medium sand. The lower outwash overlies the Gardiners Clay throughout most of the study area. Where the Gardiners Clay is absent, the lower outwash directly overlies the Monmouth Group (fig. 9D). At least four borings drilled during this study appear to have reached the lower outwash (S126753, S125381, S125990, and S124399; figs. 5 and 8), two of which penetrated the full thickness (S126753 and S124399).

\section{"20-Foot" Clay}

The "20-foot" clay is lithologically similar to the Gardiners Clay - typically grayish-green to gray clay that contains a few sand and silt beds - and has the same fossil content (Doriski and Wilde-Katz, 1983). The "20-foot" clay overlies the lower outwash in the southwestern part of the study area but is absent beneath the west-central part of Fire Island (Doriski and Wilde-Katz, 1983) (figs. 10 and 11). The unit does not appear to have been penetrated by any borings drilled during this study (fig. 8) and is assumed to be absent in the remainder of the study area (figs. 10 and 11).

\section{Upper Outwash}

The upper outwash represents the uppermost Pleistocene unit of the upper glacial aquifer. The upper outwash consists primarily of brown sand that is coarser grained and contains more gravel than that of the lower outwash (Doriski and Wilde-Katz, 1983); in the current study, the upper outwash was found to generally consist of fine to coarse sand, locally with some gravel and streaks of silt and clay. The upper outwash overlies the "20-foot" clay in the southwestern part of the study area (Doriski and Wilde-Katz, 1983). Where the "20-foot" clay is absent, the upper outwash directly overlies the lower outwash. The upper outwash extends to land surface and constitutes the surficial hydrogeologic unit along the southern shore of the Long Island mainland and locally along the seabed in back-bay (estuary) areas (Goodbred and others, 2005) and ocean areas offshore (Schwab and others, 2000). At least eight borings drilled during this study appear to have reached the upper outwash (S126753, S125380, S125381, S125382, S125990, S125385, S125369, and S124399; figs. 5 and 8), four of which appear to have penetrated the full thickness (S126753, S125381, S125990, and S124399).

\section{Holocene Deposits}

Holocene deposits that overlie Late Pleistocene deposits beneath back-bay areas, Fire Island, and most ocean areas are separated into an extensive sequence of lagoonal deposits overlain by four principally surficial units - estuarine mud, seagrass beds, peat deposits, and barrier island and shelf sands.

\section{Lagoonal Deposits}

Cores collected during this study, and those previously collected from Great South Bay (Goodbred and Usher, 2001; Goodbred and others, 2005; LoCicero, 2006), indicate a sequence of fine- to coarse-grained marine deposits of Holocene age generally overlies Pleistocene deposits beneath Fire Island and adjacent back-bay areas. The Holocene deposits consist primarily of fine sand and silt with beds of medium to coarse sand and layers of clay and silt (LoCicero, 2006). These deposits presumably include estuarine mud, relict seagrass beds, and peat deposits interbedded with floodtidal-shoal, inlet-fill, and overwash deposits. This sequence of fine- to coarse-grained deposits likely resulted from landward barrier-island migration and a gradually rising sea level and is hereafter collectively referred to as lagoonal deposits. 
$\boldsymbol{B}$

$B^{\prime}$

METERS

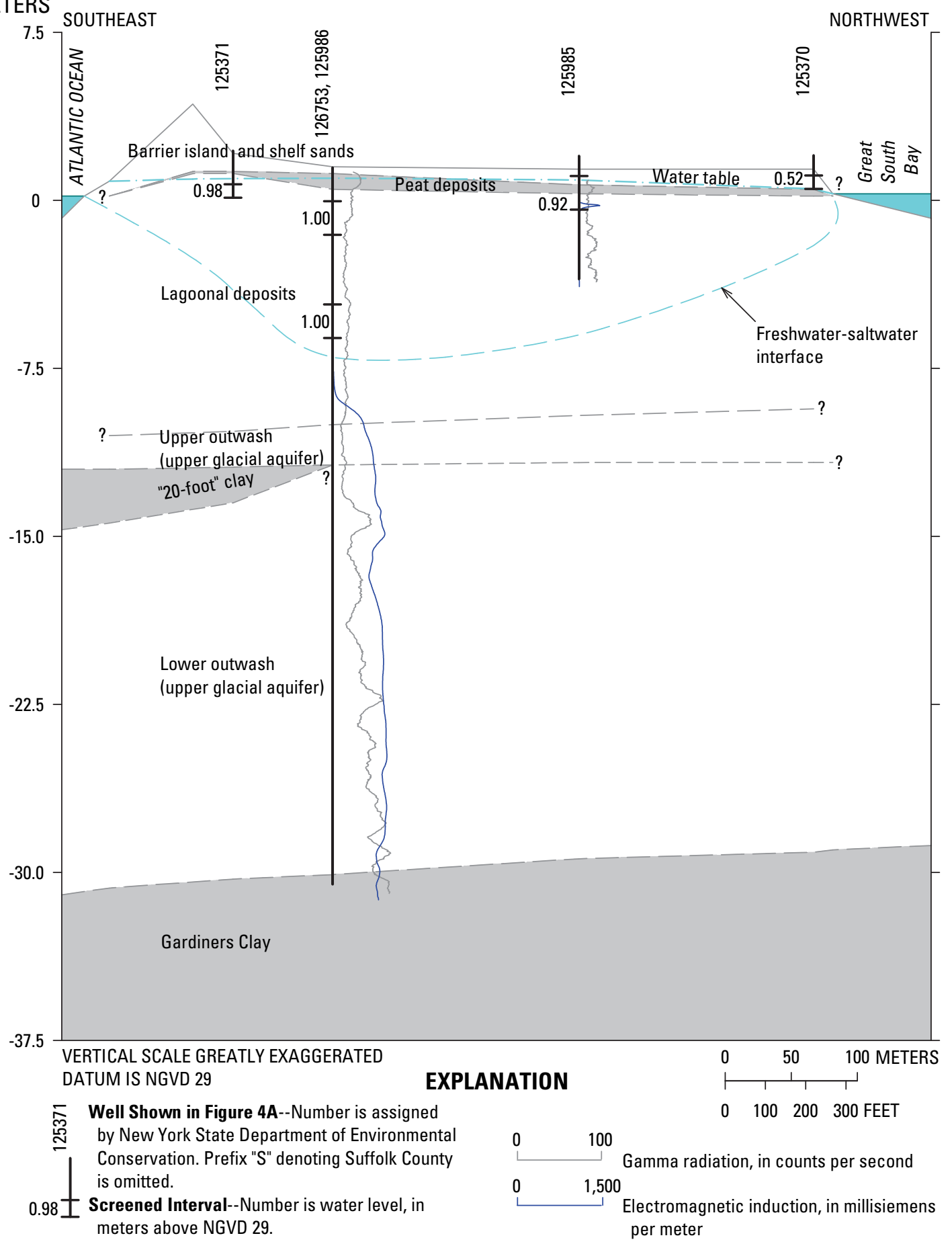

Figure 8. Vertical sections $B-B^{\prime}$ through $E-E^{\prime}$ showing hydrogeologic units, freshwater-saltwater interface, and wells with screened intervals in local study areas, and water-table altitude and groundwater levels during October 31-November 1, 2005, on Fire Island, Suffolk County, N.Y. (Section locations are shown in figure 4. NGVD 29, National Geodetic Vertical Datum of 1929) 
C

METERS

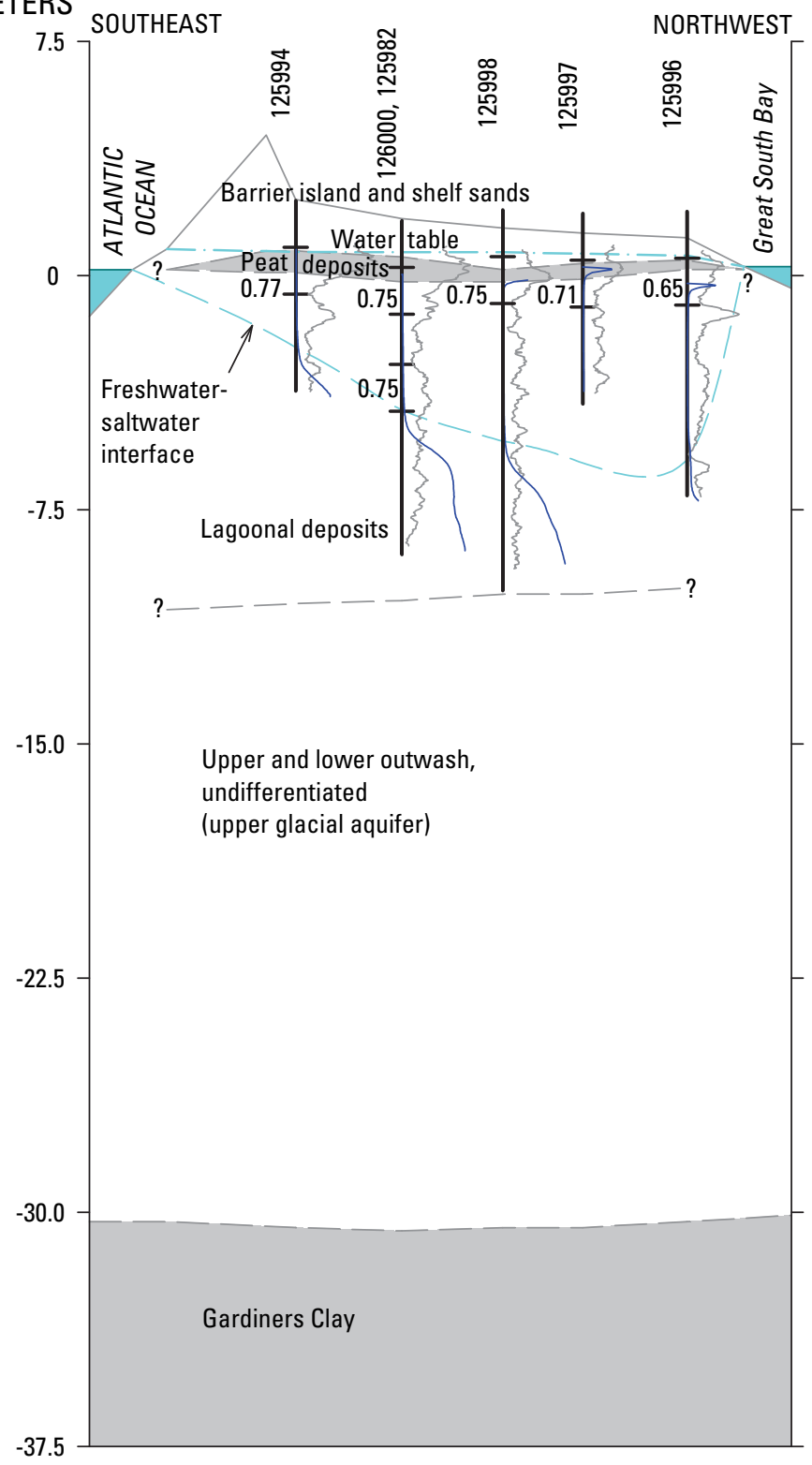

$C^{\prime}$

EXPLANATION

Well Shown in Figure 4B--Number is 오 ․ assigned by New York State Department of Environmental Conservation. Prefix "S" denoting Suffolk County is omitted.

0.77士 Screened Interval--Number is water level, in meters above NGVD 29.

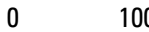

100

Gamma radiation, in counts per second

$0 \quad 1,500$

Electromagnetic induction in millisiemens per meter

VERTICAL SCALE GREATLY EXAGGERATED DATUM IS NGVD 29

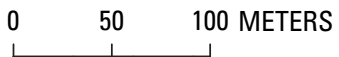

$0 \quad 100 \quad 200 \quad 300$ FEET

Figure 8. Vertical sections $B-B^{\prime}$ through $E-E^{\prime}$ showing hydrogeologic units, freshwater-saltwater interface, and wells with screened intervals in local study areas, and water-table altitude and groundwater levels during October 31-November 1, 2005, on Fire Island, Suffolk County, N.Y. (Section locations are shown in figure 4. NGVD 29, National Geodetic Vertical Datum of 1929)—Continued 
D

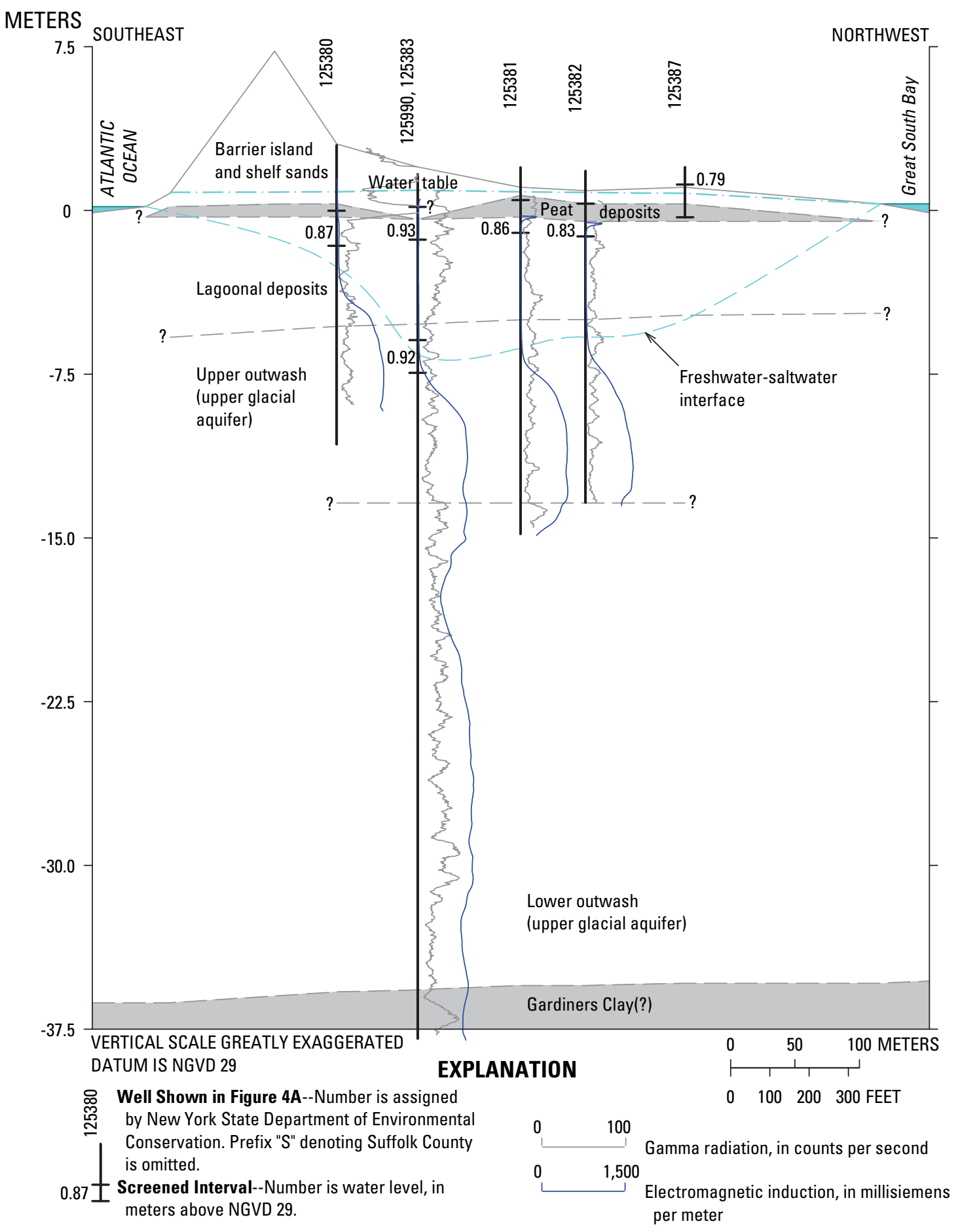

Figure 8. Vertical sections $B-B^{\prime}$ through $E-E^{\prime}$ showing hydrogeologic units, freshwater-saltwater interface, and wells with screened intervals in local study areas, and water-table altitude and groundwater levels during October 31-November 1, 2005, on Fire Island, Suffolk County, N.Y. (Section locations are shown in figure 4. NGVD 29, National Geodetic Vertical Datum of 1929)—Continued 


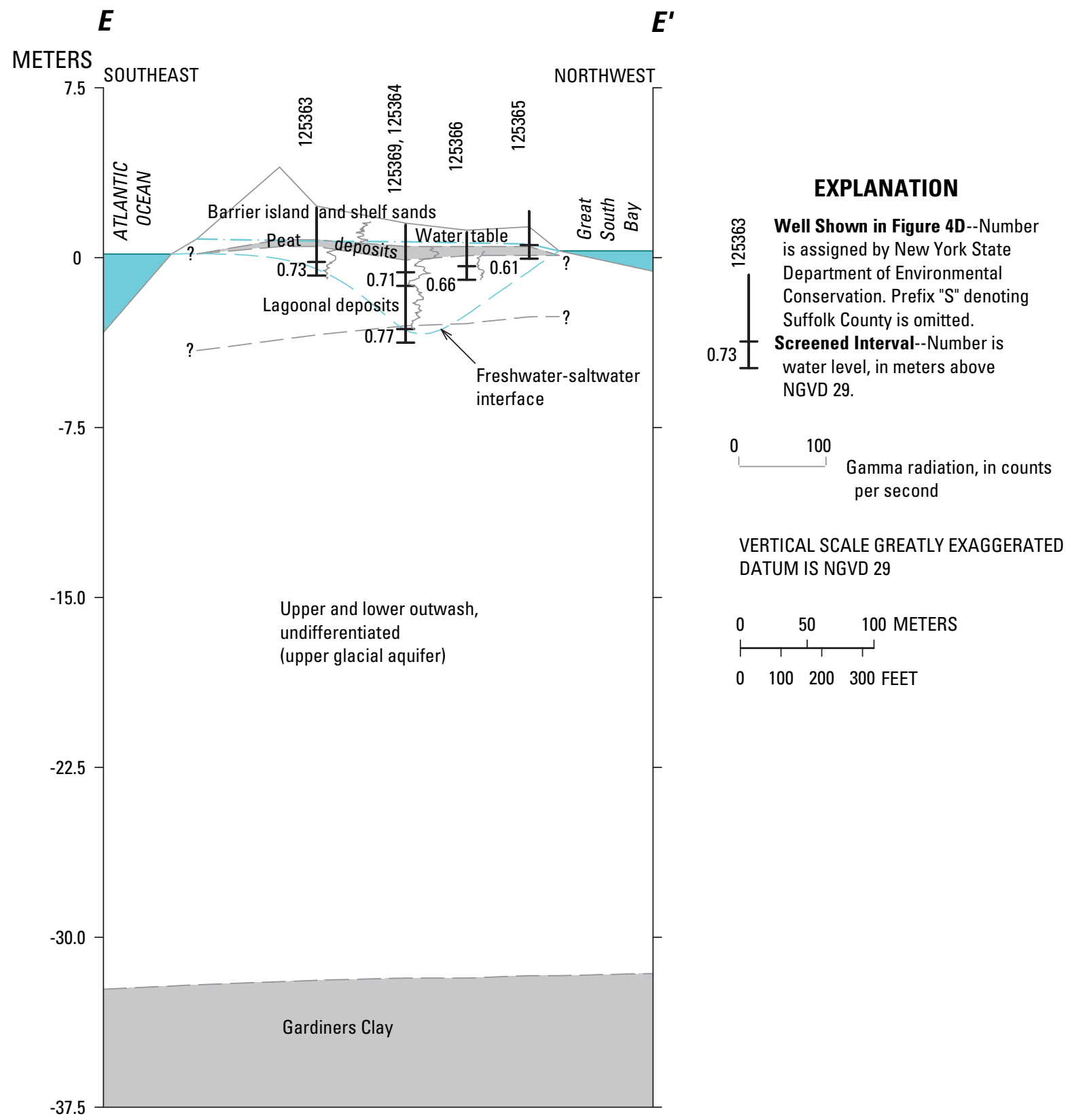

Figure 8. Vertical sections $B-B^{\prime}$ through $E-E$ showing hydrogeologic units, freshwater-saltwater interface, and wells with screened intervals in local study areas, and water-table altitude and groundwater levels during October 31-November 1, 2005, on Fire Island, Suffolk County, N.Y. (Section locations are shown in figure 4. NGVD 29, National Geodetic Vertical Datum of 1929)—Continued 

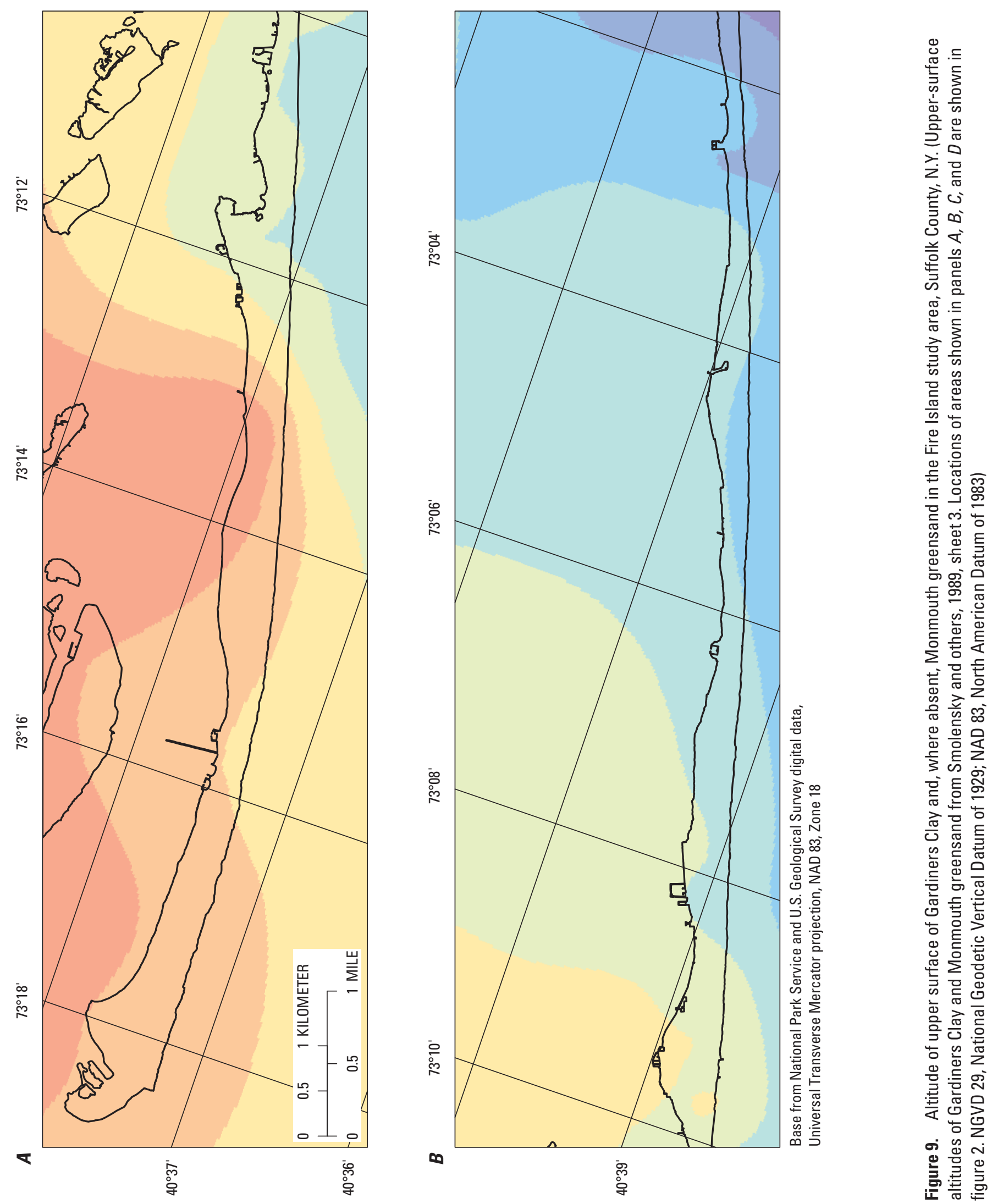

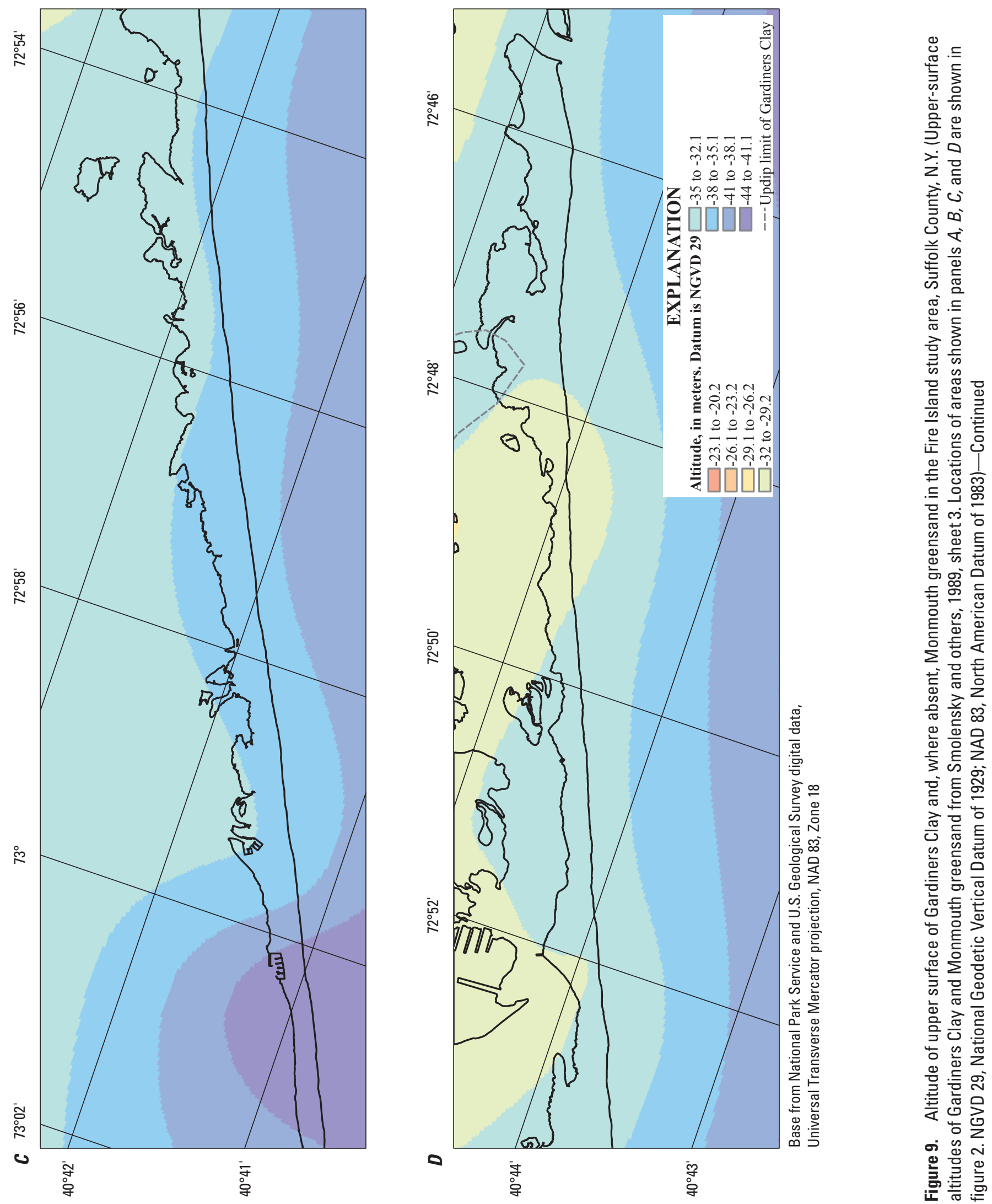

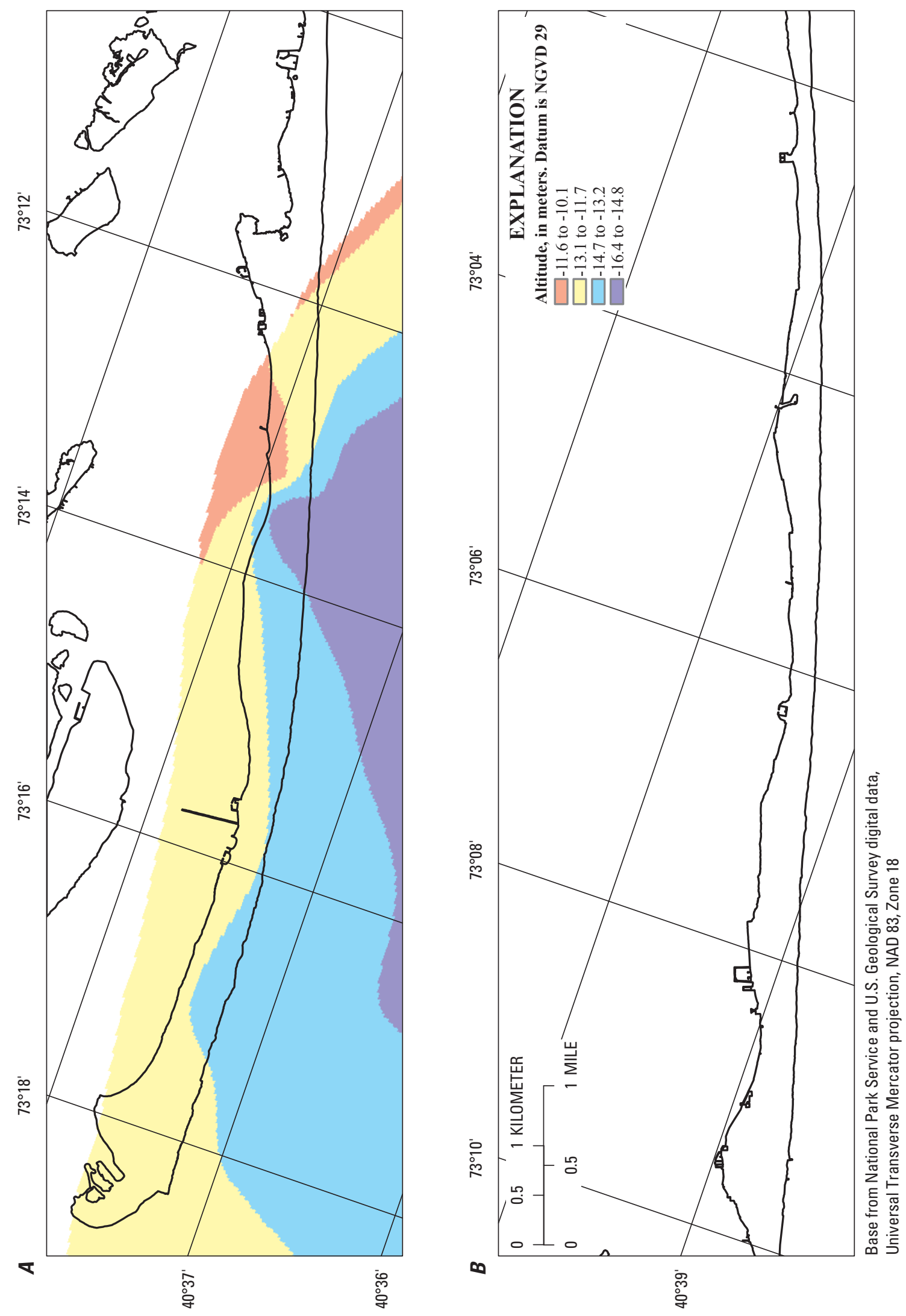

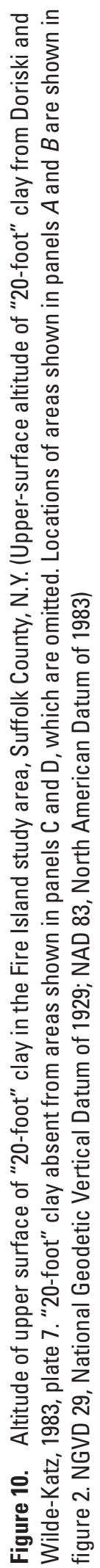



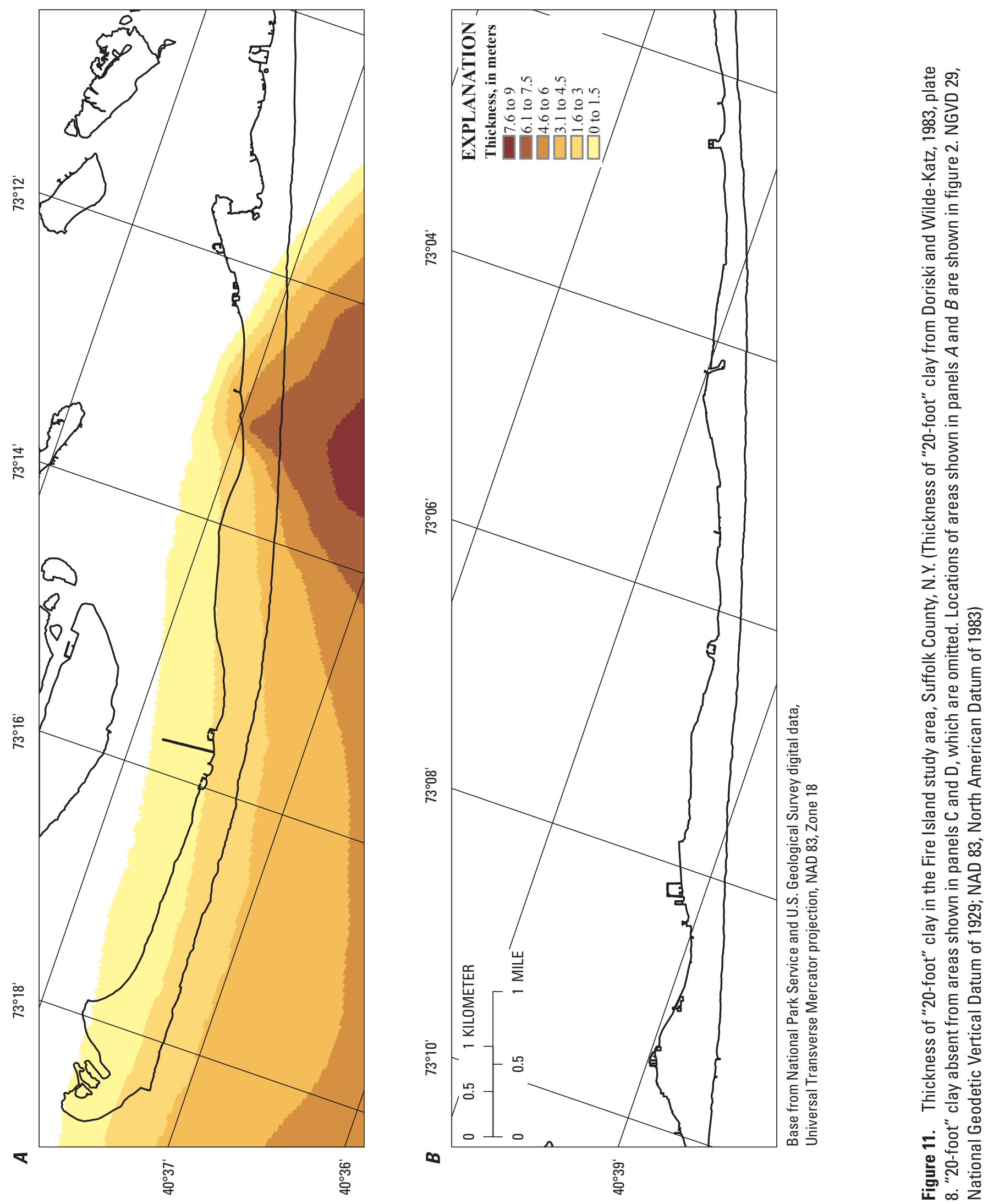
Lagoonal deposits that constitute the surficial hydrogeologic unit appear to be present in back-bay areas characterized by unconsolidated sediments (fig. 12) and are presumed to be present in other areas west of Watch Hill and in main channels from this vicinity eastward that are characterized by unknown benthic habitat, as mapped by Greenhorne and O'Mara, Inc. (2003). The lagoonal deposits appear to have been penetrated by all but four borings drilled during this study (S125370, S125371, S125387, and S125365; figs. 5 and 8), and eight appear to have penetrated the full thickness (S126753, S125380, S125381, S125382, S125990, S125385, S125369, and S124399).

\section{Estuarine Mud}

Estuarine mud overlies the lagoonal deposits and constitutes the surficial hydrogeologic unit locally in backbay areas (fig. 12). This unit is present in embayments characterized by mud and is presumed to be found in other embayments and secondary channels from Watch Hill eastward that are characterized by unknown benthic habitat (Greenhorne and O'Mara, Inc., 2003); the unit also is inferred to be present in harbors at Sailors Haven, Fire Island Pines, and Davis Park (fig. 3). Cores of estuarine mud collected previously from various parts of Great South Bay indicate the estuarine mud consists primarily of clay and silt with some fine sand (Jones and Schubel, 1980; Greenhorne and O’Mara, Inc., 2003; LoCicero, 2006).

\section{Seagrass Beds}

Seagrass beds overlie the lagoonal deposits and constitute the surficial hydrogeologic unit in most back-bay areas from Watch Hill eastward and locally west of this vicinity (fig. 12). This unit is present in shallow areas characterized by submerged rooted vascular plants (hereafter referred to as SRV, Greenhorne and O'Mara, Inc., 2003). Cores collected from areas of Great South Bay mapped by Jones and Schubel (1980) or Greenhorne and O'Mara, Inc. (2003) as containing seagrass or SRV beds, respectively, suggest that the inorganic sediments associated with this unit consist mostly of fine sand and silt with some medium sand (LoCicero, 2006).

\section{Peat Deposits}

Peat outcrops on the beach foreshore are uncovered regularly along the back bays (Nordstrom and Jackson, 2005) and in some places along the Atlantic Ocean (fig. 13); buried peat deposits also are reported to underlie areas of the Fire Island interior and those in the adjacent back bays (Bokuniewicz and Pavlik, 1990; Collier, 2006). The peat deposits that overlie the lagoonal deposits are described locally as bog in drillers' logs for many borings on Fire Island and were correlated with cores from hand augering and gamma-ray borehole logging conducted during this study. Peat deposits consist primarily of black peat with some medium to fine sand. The deposits generally are present near local mean sea level throughout the areas where drilling was conducted. Peat deposits, which are inferred to be mostly continuous beneath Fire Island and adjacent back-bay islands, also are present in Fire Island wetland areas associated with reedgrass marsh, low salt marsh, high salt marsh, northern interdunal cranberry swale, and brackish interdunal swale (Klopfer and others, 2002). They also are presumed to be present in adjacent back-barrier intertidal zones characterized by tidal marsh as mapped by Greenhorne and O'Mara, Inc. (2003); in these areas, peat deposits constitute the surficial hydrogeologic unit (fig. 12). The peat deposits generally were penetrated in all borings drilled during this study, except at one (S125990, figs. 5 and 8) where the deposits seem to be locally absent. Whether the absence of this unit in the shallow subsurface indicates nondeposition, erosion, or manmade excavation (such as for buried utilities) is unknown.

\section{Barrier Island and Shelf Sands}

Coarse-grained deposits, which consist primarily of fine to medium sand, overlie the buried peat deposits beneath Fire Island (fig. 12) and generally constitute the surficial hydrogeologic unit. These sediments probably overlie the lagoonal deposits and underlying upper outwash in most ocean areas. They likely include contiguous lenses of beach, overwash, and eolian deposits onshore and inner-shelf deposits offshore. These lithologically similar deposits are difficult to distinguish and are undifferentiated in this report; hereafter, they are referred to as barrier island and shelf sands. This unit was fully penetrated in most borings with the exception of 11 
(S125995, S125984, S125985, S126753, S125370, S125986, S125996, S125997, S125381, S125382, and S125387; figs. 5 and 8); the unit was not observed in these boreholes.

\section{Hydrologic Setting}

Fresh groundwater in the shallow aquifer system on Fire Island is contained within a hydraulically isolated freshwater flow system that extends through the Holocene and Pleistocene hydrogeologic units. This freshwater flow system is bounded laterally by marine surface waters and at depth by saline groundwater (figs. 5, 7, and 8). Hydraulic heads and the movement of fresh groundwater on Fire Island are controlled by the hydraulic boundaries and aquifer properties of the freshwater flow system (figs. 4 and 8).

\section{Hydrologic Boundaries}

The natural hydrologic boundaries of the fresh groundwater reservoir on Fire Island are the hydrologic features that bound the extent of the freshwater flow system and, hence, the hydraulic stresses that control the rate at which freshwater enters and exits the system. Recharge to the system occurs across the water table where freshwater enters through infiltration of precipitation and as return flow of publicsupply water (in unsewered areas). Discharge boundaries are near the shore where freshwater exits as seepage across the seabed into marine surface waters (shoreline underflow) or as seepage through confining layers into saline groundwater (subsea underflow). Discharge boundaries also are where the land surface intersects the water table and freshwater exits as wetland evapotranspiration. A flow-through condition is provided by topographic depressions in the land surface that intersect the water table to form ponds where shallow groundwater discharges to the pond at the upgradient side and pond water recharges the water-table aquifer at the downgradient side (Masterson and others, 1996). The freshwater-saltwater interface, where freshwater is separated from denser saltwater by a zone of diffusion, acts as a relatively impermeable boundary that moves gradually in response to changes in the balance between recharge and discharge.

\section{Precipitation and Recharge}

The natural source of freshwater to the water table is recharge from precipitation. The amount of recharge is determined by the pattern and rate of precipitation and by the amount of precipitation lost as evapotranspiration and, to a much lesser extent, as surface runoff. Although precipitation in Suffolk County is fairly evenly distributed throughout the year (Peterson, 1987), evapotranspiration is greatest during the summer; therefore, most recharge takes place during the fall, winter, and spring. Seasonal fluctuations in recharge-for example, between summer and winter - generally are greater than any annual to decadal fluctuations.

Long-term daily precipitation-measurement records were obtained from the National Climatic Data Center (NCDC) (National Climatic Data Center, 2006) for nearby discontinued and active stations at Patchogue and Islip, respectively (fig. 2), and were used to calculate the annual and long-term mean precipitation rates in table 3. Comparison with 1984-96 mean precipitation rates at Patchogue and Islip indicate that annual and mean rates for 2003-05 at Islip generally were consistent with the long-term (1938-96) mean rate at Patchogue (table 3).

Estimates of the percentage of precipitation that becomes recharge in land areas of Long Island were reviewed and summarized by Peterson (1987) and generally are consistent with a recharge rate equal to about 50 percent of mean annual precipitation. An alternative method of calculating recharge in these areas (Steenhuis and others, 1985) specifies an annual recharge rate equal to 75 to 90 percent of precipitation from October 15 through May 15. Values of recharge to the water table in land areas of Long Island that are calculated by both methods from the Patchogue and Islip records are shown in table 3.

Recharge to the water table through fresh surface-water bodies in Suffolk County has been calculated by Schubert (1998) and Misut and others (2004) as the difference between long-term mean annual precipitation (table 3 ) and annual lake evaporation. These studies determined the long-term mean rate of lake evaporation on Long Island to be about $85.4 \mathrm{~cm} / \mathrm{yr}$, as calculated from an average pan coefficient of 0.7 , which relates the rate of annual lake evaporation to annual pan evaporation (Linsley and Franzini, 1979), and mean 

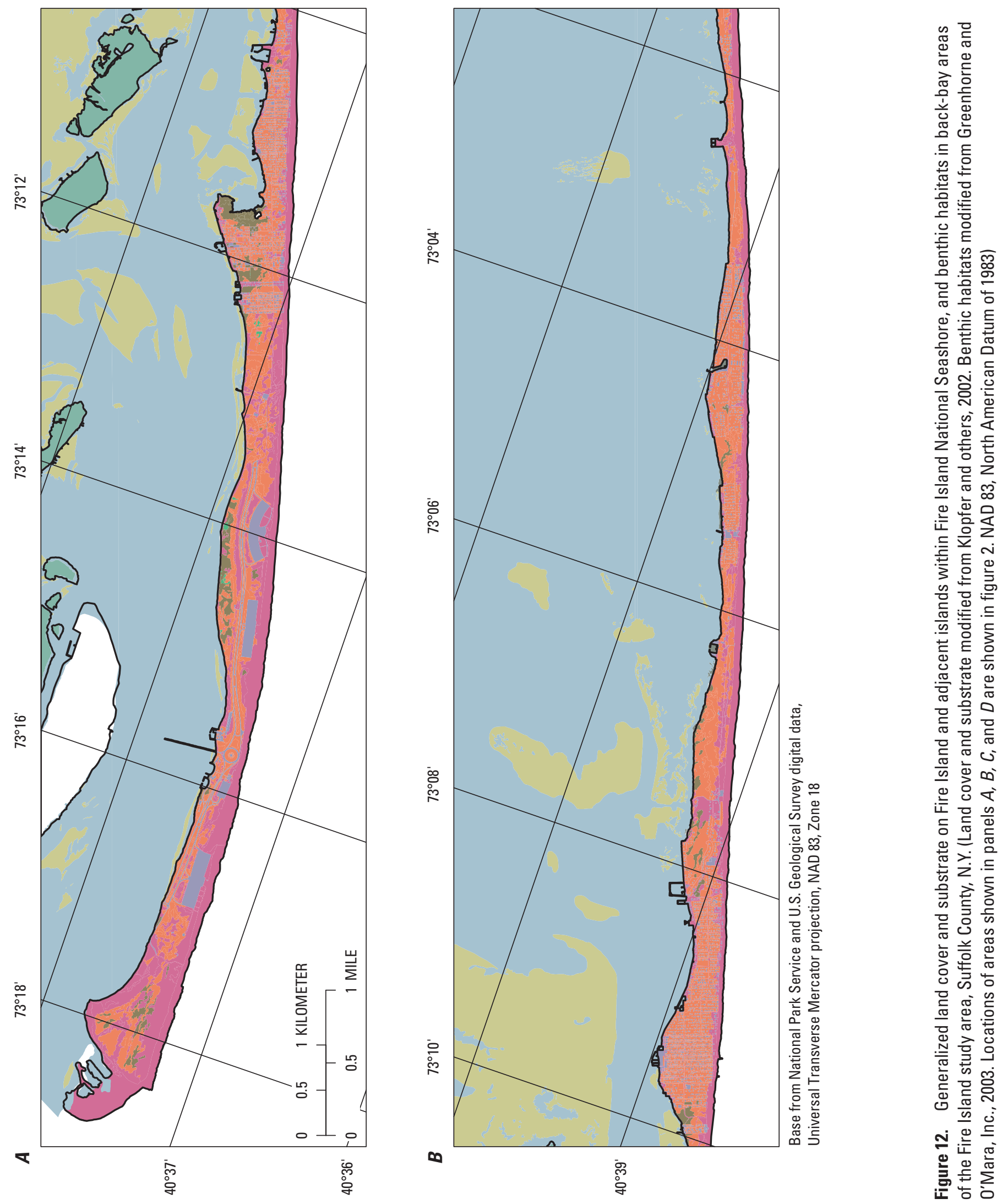

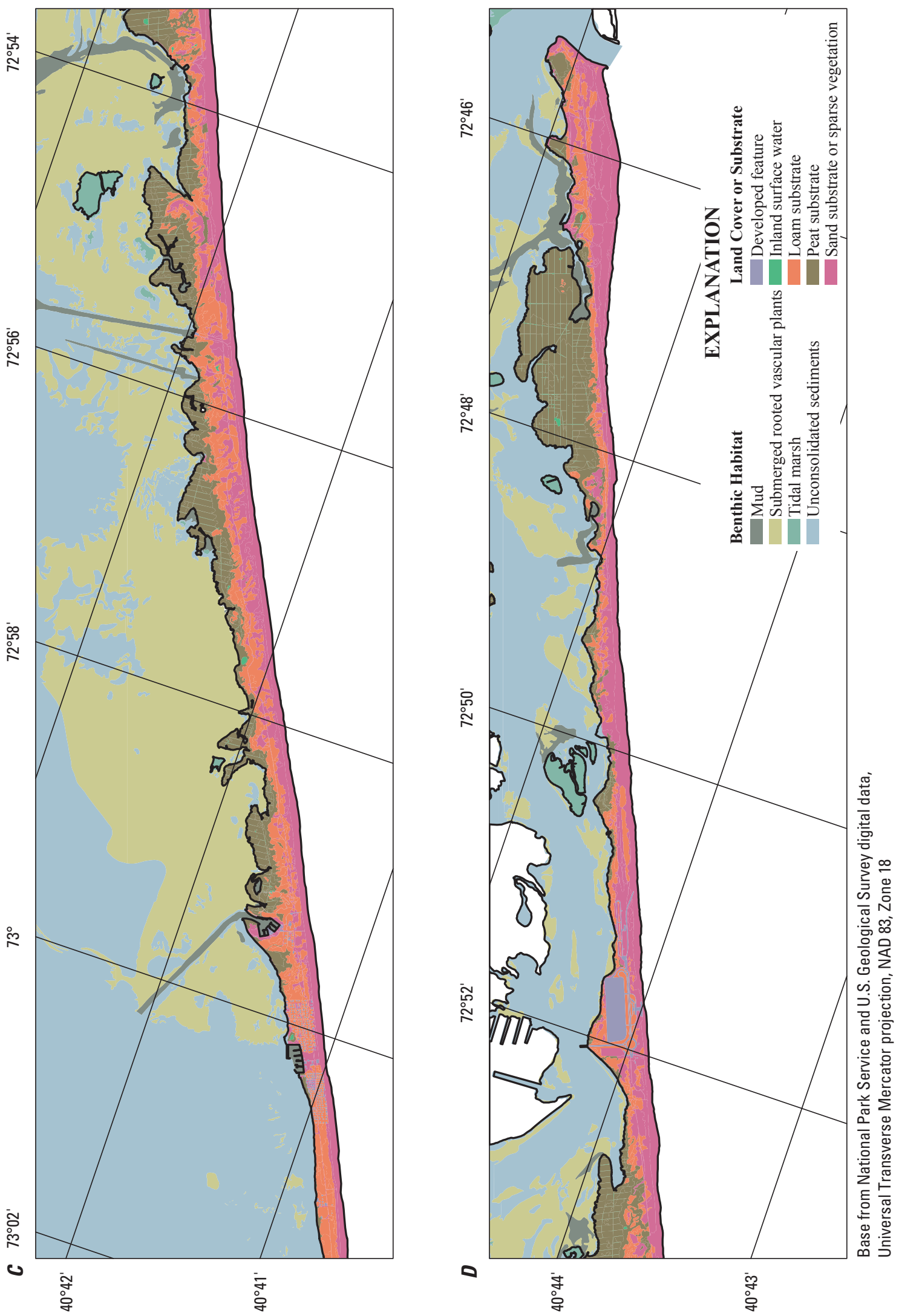

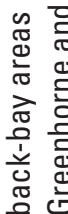

드은

흄 임

증 응

이

휴

믇즌

일 总

ธิ ธิ

๗ัฐ ฮั

즌 을

을 क्षे

之

을 은 을

क స ल

흔 는은

흐

들 잉

की 능 음

元

क 흥

跤

屯 ¿

票焉

음 क

흥 क음

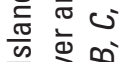

Ф 어 ব

녿음

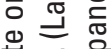

흔

क

क 产 豆

तั

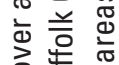

ن ज苛

ธั ฮี่

흐 휴

츠 흥

힐 ल

뜸 응

ब के

ํㅡㄹ

혼 


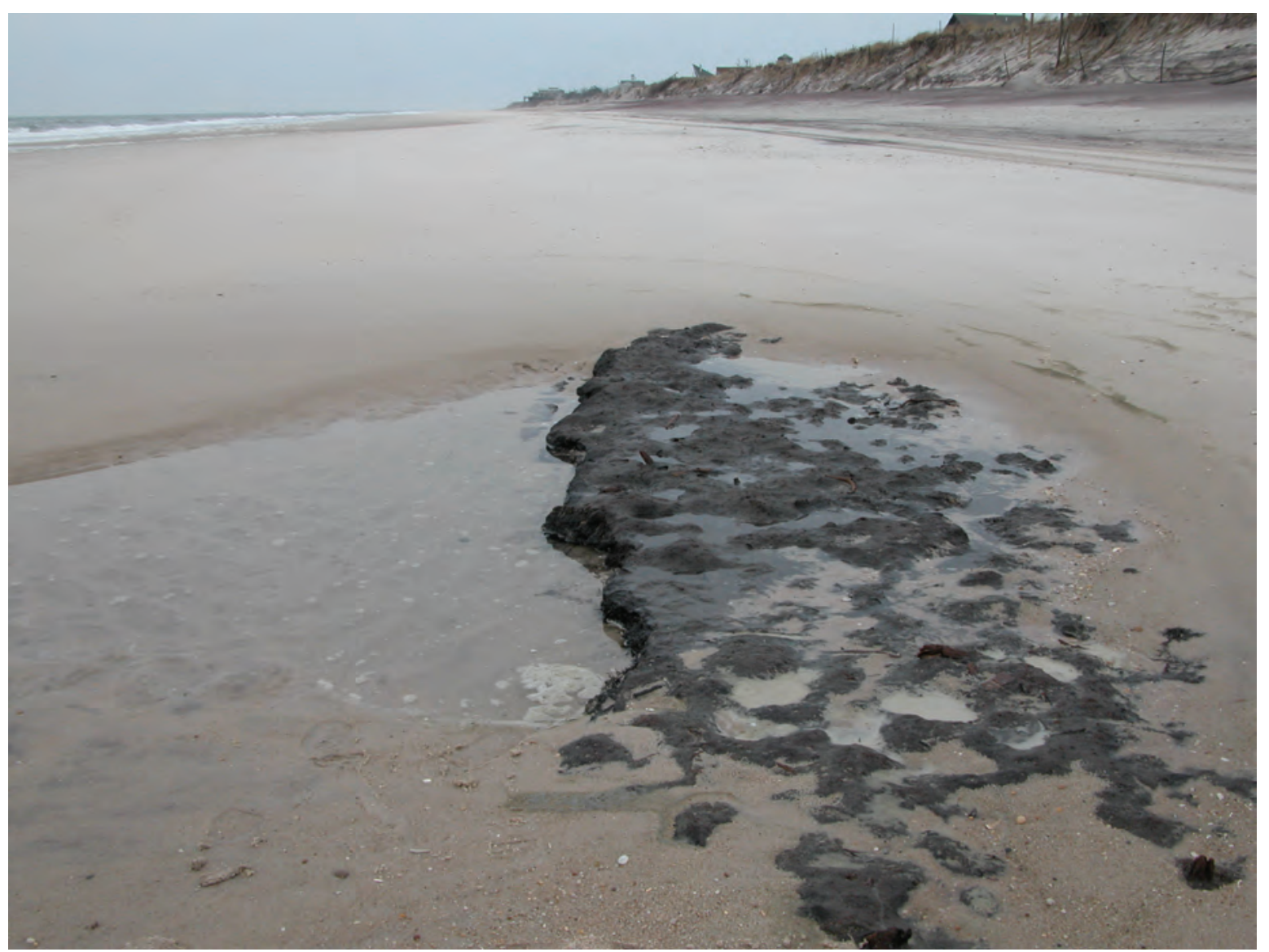

Figure 13. Photograph of ocean shore between Watch Hill and Davis Park showing peat deposits occasionally uncovered on the Atlantic Ocean beaches of Fire Island, Suffolk County, N.Y. (Photograph from Paula Valentine, National Park Service, written commun., 2010.)

Table 3. Annual and long-term mean precipitation amounts at Patchogue and Islip, Suffolk County, N.Y.

[Station locations are shown in figure 2. Data from National Climatic Data Center, 2006]

\begin{tabular}{|c|c|c|c|c|c|}
\hline \multirow{3}{*}{ Period } & \multicolumn{5}{|c|}{ Precipitation, in centimeters } \\
\hline & \multicolumn{2}{|c|}{ Calendar year } & \multirow[b]{2}{*}{ Total } & \multirow[b]{2}{*}{75 percent of total } & \multirow[b]{2}{*}{90 percent of total } \\
\hline & Total & 50 percent of total & & & \\
\hline \multicolumn{6}{|c|}{ PATCHOGUE } \\
\hline${ }^{1} 1938-96$ & 119.6 & 59.79 & 71.22 & 53.41 & 64.11 \\
\hline 1984-96 & 127.2 & 63.57 & 72.79 & 54.58 & 65.50 \\
\hline \multicolumn{6}{|c|}{ ISLIP } \\
\hline 1984-96 & 116.1 & 58.04 & 65.58 & 49.20 & 59.03 \\
\hline 2003 & 126.8 & 63.42 & 63.85 & 47.90 & 57.48 \\
\hline 2004 & 99.59 & 49.81 & 57.15 & 42.87 & 51.43 \\
\hline 2005 & 104.3 & 52.14 & 56.92 & 42.70 & 51.23 \\
\hline $2003-05$ & 110.2 & 55.12 & 59.31 & 44.47 & 53.39 \\
\hline $1984-2005$ & 115.2 & 57.58 & 65.94 & 49.45 & 59.33 \\
\hline
\end{tabular}

'Precipitation data are incomplete for 1947, 1959, and 1965-66; data for these years were not used to compute long-term mean value. 
annual evaporation of $122 \mathrm{~cm}$ from a land pan at Mineolalocated in central Nassau County (fig. 1) - during 1949-60 (Pluhowski and Kantrowitz, 1964).

Maximum summer temperatures are lower along the southern shore of the Babylon-Islip area than in its northern and central parts, a factor that should decrease evaporation (Pluhowski and Kantrowitz, 1964). Thus, evaporation on Fire Island and in other nearshore areas probably is considerably less than in the Long Island interior. Daily evaporation records obtained from the NCDC (National Climatic Data Center, 2007) for a discontinued land pan at Greenport-located near the end of the peninsula that constitutes Long Island's North Fork (fig. 1) - likely provide a reasonable approximation of evaporation on Fire Island. These records, which generally are available only for the months of May through October during 1958-97, were combined with long-term mean values from Mineola for the remaining months (fig. 14) to estimate mean annual values. The resulting rates of long-term mean annual pan and annual lake evaporation at Greenport are about 106 and $74.3 \mathrm{~cm} / \mathrm{yr}$, respectively. These decreased rates of evaporation are assumed to yield increased rates of recharge to the water table on Fire Island.
The sparse vegetation and sandy soils that constitute the surficial hydrogeologic unit on parts of Fire Island also likely result in decreased rates of groundwater evapotranspiration. Previous investigations found evaporation through unvegetated clay loam, such as is present on Fire Island, decreased from 25 percent to less than 10 percent of pan evaporation with a water-table drop from about 0.3 to $0.9 \mathrm{~m}$ below land surface (White, 1932; Todd, 1980; Kontis and others, 2004). These same studies found groundwater evapotranspiration rates declined as the depths to the capillary fringe increased and were zero below extinction depths of less than $3.0 \mathrm{~m}$ to as much as $7.6 \mathrm{~m}$.

\section{Groundwater Discharge}

Groundwater in the freshwater flow system of Fire Island discharges to shore and subsea-discharge areas or is lost as wetland evapotranspiration. Most freshwater discharge occurs as shoreline and subsea underflow, but the diffuse character and location of this outflow make the rate difficult to measure. The discharge of fresh groundwater is controlled by the hydraulic properties of the freshwater flow system,

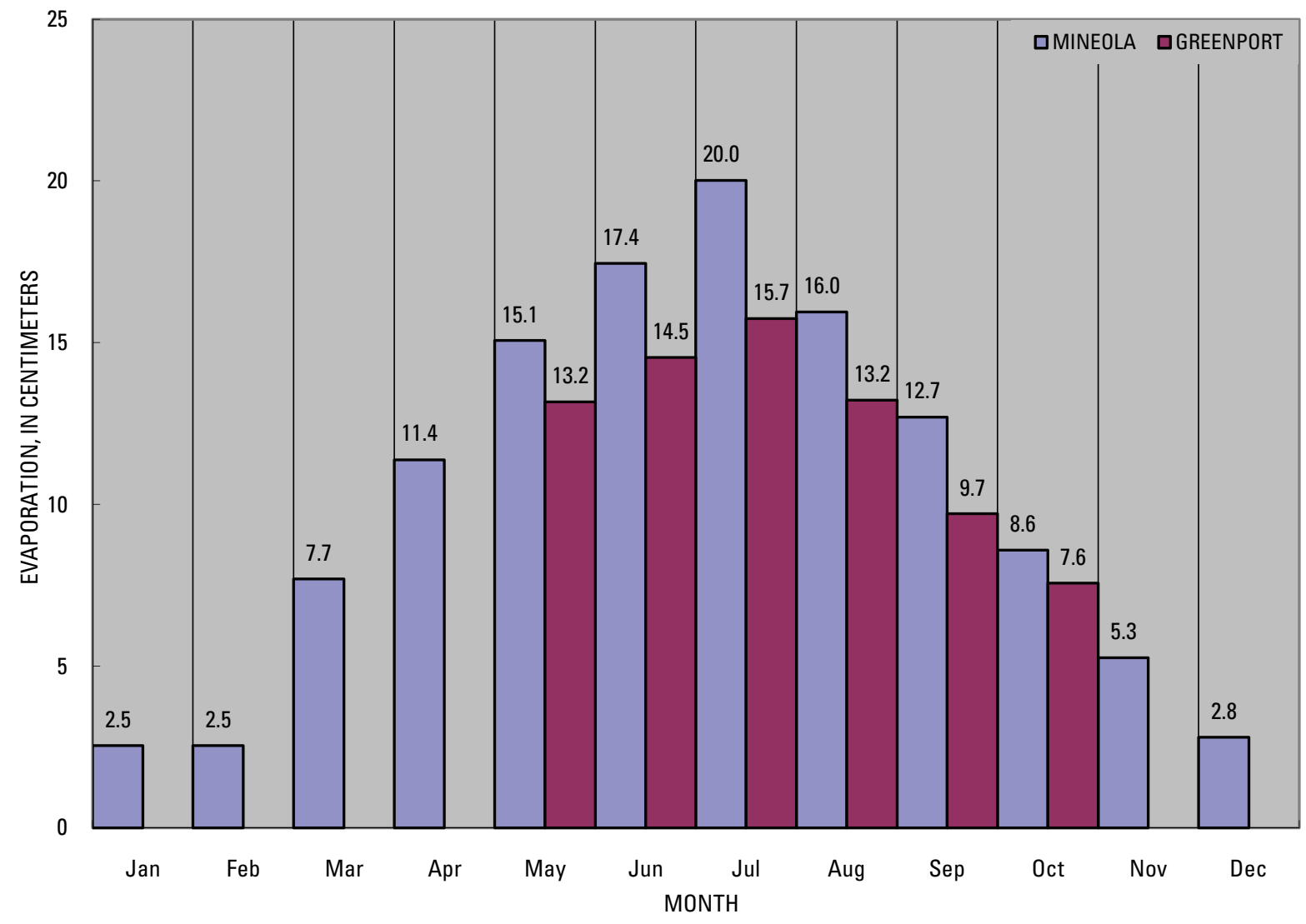

Figure 14. Long-term mean monthly evaporation at land pans in Greenport and Mineola, Long Island, N.Y. (Numbers above shaded bars are evaporation values. Evaporation data for Greenport from National Climatic Data Center, 2007; data for Mineola from Pluhowski and Kantrowitz, 1964) 
the leakance of the boundary, and the hydraulic gradient across the boundary. The hydraulic gradient is determined largely by the time-averaged level of the surface waters that has been known to vary spatially because of differences in local mean sea level (MSL). The mean surface-water level also has been found to vary spatially and temporally near the shore because of the effects of breaking waves (wave setup and setdown) and asymmetrical tidal infiltration and seepage (tidal pumping), each of which can elevate the water table at this boundary creating a condition commonly referred to as water-table overheight (Nielsen, 1990; Hanslow and Nielsen, 1993; Turner and others, 1996; Nielsen, 1999).

\section{Local Mean Sea Level}

Estimates of the difference between local MSL and NGVD 29 obtained or calculated from published and unpublished relations between tidal and fixed datums at active and discontinued National Ocean Service (NOS) tidal benchmark locations in southeastern New York and northeastern New Jersey (fig. 1) are summarized in tables 4-7 (U.S. Department of Commerce, 1969; J.R. Hubbard, National Ocean Service, written commun., 1993; National Geodetic Survey, 2006; National Ocean Service, 2006a). These values were supplemented with estimates of the local MSL-NGVD 29 difference calculated in this study for a series of points in adjacent ocean areas (fig. 1) using the VDatum ${ }^{2}$ program. A comparison of this VDatum program estimate for the active NOS station at Sandy Hook, N.J., with the local MSLNGVD 29 difference from this station for the most recent

\footnotetext{
${ }^{2}$ A datum transformation software developed jointly by the National Oceanic and Atmospheric Administration's Office of Coast Survey and National Geodetic Survey (Hess, 2001).
}

Table 4. Published relations between tidal and fixed datums for 1983-2001 tidal epoch at six active National 0cean Service tidal benchmark stations in southeastern New York and northeastern New Jersey.

[All values are in meters. Locations of stations 8510560,8512769 , and 8531680 are shown in figure 1 . Locations of stations 8513825,8515102 , and 8515186 are shown in figure 2. Published relations between tidal datums (MHHW, mean higher high water; MSL, mean sea level; and MLLW, mean lower low water) at all stations, and between tidal datums and North American Vertical Datum of 1988 (NAVD 88) at stations 8510560, 8515186, and 8531680 from National Ocean Service, 2006. Relations between NAVD 88 and National Geodetic Vertical Datum of 1929 (NGVD 29) at all stations, and between tidal and fixed datums at stations 8512769, 8513825 and 8515102, from National Geodetic Survey, 2006]

\begin{tabular}{|c|c|c|c|c|c|c|}
\hline \multirow{2}{*}{ Station } & \multicolumn{2}{|c|}{ MHHW minus datum } & \multicolumn{2}{|c|}{ MSL minus datum } & \multicolumn{2}{|c|}{ Datum minus MLLW } \\
\hline & NAVD 88 & NGVD 29 & NAVD 88 & NGVD 29 & NAVD 88 & NGVD 29 \\
\hline 8510560 Montauk, Fort Pond Bay, N.Y. & 0.37 & 0.66 & -0.02 & 0.27 & 0.40 & 0.11 \\
\hline 8513825 Smith Point Bridge, Narrow Bay, N.Y. & 0.20 & 0.52 & -0.02 & 0.30 & 0.25 & -0.08 \\
\hline 8515102 Bay Shore, Watchogue Creek Entrance, N.Y. & 0.20 & 0.57 & 0.00 & 0.38 & 0.18 & -0.20 \\
\hline 8531680 Sandy Hook (Fort Hancock), N.J. & 0.73 & 1.06 & -0.07 & 0.26 & 0.86 & 0.53 \\
\hline
\end{tabular}

Table 5. Published relations and calculated difference between National Geodetic Vertical Datum of 1929 and local mean low water datum for the 1941-59 and 1983-2001 tidal epochs at four active National Ocean Service tidal benchmark stations in southeastern New York and northeastern New Jersey.

[All values are in meters. Locations of stations 8510560 and 8531680 are shown in figure 1. Locations of stations 8515102 and 8515186 are shown in figure 2 . Data for 1941-59 tidal epoch from J.R. Hubbard, National Ocean Service, written commun., 1993. Published relations between North American Vertical Datum of 1988 (NAVD 88) and mean low water (MLW) for 1983-2001 tidal epoch at stations 8510560, 8515186, and 8531680 from National Ocean Service, 2006a. Relations between NAVD 88 and National Geodetic Vertical Datum of 1929 (NGVD 29) at these stations and between fixed and MLW datums at station 8515102 from National Geodetic Survey, 2006]

\begin{tabular}{lccc}
\hline \multirow{2}{*}{ Station } & \multicolumn{3}{c}{ NGVD 29 minus MLW for tidal epoch(s) } \\
\cline { 2 - 4 } & $\mathbf{1 9 4 1 - 5 9}$ & $\mathbf{1 9 8 3 - 2 0 0 1}$ & $\mathbf{1 9 4 1 - 5 9 ~ m i n u s ~ 1 9 8 3 - 2 0 0 1}$ \\
\hline 8510560 Montauk, Fort Pond Bay, N.Y. & 0.24 & 0.05 & 0.19 \\
8515102 Bay Shore, Watchogue Creek Entrance, N.Y. & -0.11 & -0.22 & ${ }^{1} 0.10$ \\
8515186 Fire Island Coast Guard Station, N.Y. & 0.09 & 0.02 & ${ }^{1} 0.08$ \\
8531680 Sandy Hook (Fort Hancock), N.J. & 0.55 & 0.47 & ${ }^{1} 0.07$ \\
\hline
\end{tabular}

${ }^{1}$ Amount may not equal the sum of values because of rounding to significant digits. 
Table 6. Published and calculated relations between local mean low water and mean tide level datums and National Geodetic Vertical Datum of 1929 for the 1941-59 tidal epoch, and estimated difference for and relation between mean tide level and National Geodetic Vertical Datum of 1929 for the 1983-2001 tidal epoch at selected discontinued National Ocean Service tidal benchmark stations, Suffolk County, N.Y.

[All values are in meters. Station locations are shown in figure 2. Published relation between National Geodetic Vertical Datum of 1929 (NGVD 29) and mean low water (MLW) for 1941-59 tidal epoch from J.R. Hubbard, National Ocean Service, written commun., 1993; which also was used with data from National Ocean Service, 2006a; and National Geodetic Survey, 2006; to estimate relation between mean tide level (MTL) and MLW for 1941-59 at Moriches Coast Guard Station, N.Y. Relation between MTL and MLW for 1941-59 tidal epoch at all other stations from U.S. Department of Commerce, 1969]

\begin{tabular}{|c|c|c|c|c|c|}
\hline \multirow[b]{2}{*}{ Station(s) } & \multicolumn{3}{|c|}{$\begin{array}{l}\text { Relations between datums } \\
\text { for } 1941-59 \text { tidal epoch }\end{array}$} & \multicolumn{2}{|c|}{$\begin{array}{l}\text { Estimated MTL minus } \\
\text { NGVD } 29 \text { for tidal epoch(s) }\end{array}$} \\
\hline & $\begin{array}{c}\text { NGVD } 29 \\
\text { minus } \\
\text { MLW }\end{array}$ & $\begin{array}{c}\text { MTL } \\
\text { minus } \\
\text { MLW }\end{array}$ & $\begin{array}{l}\text { MTL } \\
\text { minus } \\
\text { NGVD }\end{array}$ & $\begin{array}{c}\text { 1941-59 } \\
\text { minus } \\
1983-2001\end{array}$ & 1983-2001 \\
\hline Potunk Point, Moriches Bay, N.Y. & -- & 0.06 & \multirow[b]{2}{*}{${ }^{1} 0.15$} & \multirow[b]{2}{*}{${ }^{2} 0.08$} & \multirow[b]{2}{*}{${ }^{3} 0.24$} \\
\hline Eastport, Seatuck Cove, Moriches Bay, N.Y. & 0.01 & -- & & & \\
\hline Wa Wa Yanda Yacht Club, Captree Island, Great South Bay, N.Y. & -0.12 & -- & \multirow{2}{*}{0.21} & \multirow{2}{*}{${ }^{4} 0.10$} & \multirow{2}{*}{${ }^{3} 0.30$} \\
\hline West Fire Island, Great South Bay, N.Y. & -- & 0.09 & & & \\
\hline Oakbeach, Great South Bay, N.Y. & -0.10 & 0.09 & 0.18 & ${ }^{4} 0.10$ & ${ }^{3} 0.30$ \\
\hline \multicolumn{6}{|l|}{${ }^{1}$ Calculation is average for stations listed. } \\
\hline
\end{tabular}

Table 7. Relations and calculated difference between mean sea level datum and National Geodetic Vertical Datum of 1929 for the 1983-2001 tidal epoch and from the VDatum program at the National Ocean Service tidal benchmark station at Sandy Hook, N.J.

[All values are in meters. Station location is shown in figure1. Published relation between mean sea level (MSL) and North American Vertical Datum of 1988 (NAVD 88) for 1983-2001 tidal epoch from National Ocean Service, 2006a. Relation between NAVD 88 and National Geodetic Vertical Datum of 1929 (NGVD 29) from National Geodetic Survey, 2006]

\begin{tabular}{cccc}
\hline \multirow{2}{*}{ Station } & \multicolumn{3}{c}{ MSL minus NGVD 29 } \\
\cline { 2 - 4 } & VDatum & 1983-2001 & 1983-2001 minus VDatum \\
\hline 8531680 Sandy Hook (Fort Hancock), N.J. & 0.19 & 0.26 & 0.07 \\
\hline
\end{tabular}


(1983-2001) tidal epoch suggests, however, that the VDatum values for this and other locations are derived from a different (previous or superseded) tidal epoch. This discrepancy was addressed in this study by applying the difference between the actual and VDatum values for Sandy Hook to the supplementary ocean points.

\section{Wave Setup and Setdown}

Collier (2006) found that wave setup and setdown along the Atlantic Ocean shore of Fire Island resulted in an increase (setup) of about $0.085 \mathrm{~m}$ in the mean surface-water level at the shore and a similar decrease (setdown) at the approximate position of the breaker zone and underlying bar about $200 \mathrm{~m}$ offshore. Empirical relations reported by Hanslow and Nielsen (1993) and Nielsen (1999) suggest the wave setup at the shoreline is considerably higher - on the order of 40 percent of the offshore wave height, on the basis of the relations in their simplified form. Wave Information Studies (WIS) produced by the U.S. Army Corps of Engineers that generate model hindcasts of wave climate for United States coastal waters indicate the 1980-99 mean annual wave height at an ocean location offshore of eastern Fire Island is $1.1 \mathrm{~m}$ (Coastal and Hydraulics Laboratory, 2006). On the basis of these empirical relations and offshore wave-height data, the maximum wave setup along the Atlantic Ocean shore of Fire Island was estimated to be $0.44 \mathrm{~m}$.

\section{Tidal Pumping}

The asymptotic inland water-table overheight resulting from tidal pumping for the simplified case of a vertical beach face has been expressed by Nielsen (1990) as approximately:

$$
\eta_{\mathrm{v}}^{+}=A^{2} / 4 D
$$

where

$$
\begin{aligned}
\eta_{\mathrm{v}}^{+}= & \text {water-table overheight resulting from tidal } \\
& \text { pumping along a vertical beach face, } \\
A & =
\end{aligned}
$$

Along the Atlantic Ocean shore of Fire Island, the tidal amplitude is $0.44 \mathrm{~m}$, on the basis of the predicted value for nearby Moriches Inlet (National Ocean Service, 2006b). The undisturbed aquifer thickness along this shore was approximated to be the difference between mean high water and the upper surface of Holocene peat deposits, which are inferred in this study to be mostly continuous beneath Fire Island; this approximation essentially equals the tidal amplitude. The resulting estimate of water-table overheight for the simplified case of a vertical beach face is about $0.11 \mathrm{~m}$.

Solutions for the additional water-table overheight resulting from tidal pumping for the case of a sloping beach face have been derived by Nielsen (1990) and are as follows:

$$
\eta_{\beta}^{+}=0.5 \in A
$$

where

$$
\begin{aligned}
\eta_{\beta}^{+}= & \text {water-table overheight resulting from tidal } \\
& \text { pumping along a sloping beach face, } \\
A & =
\end{aligned}
$$

$$
\in=k_{\mathrm{B}} A / \tan \beta
$$

where

$$
\begin{aligned}
& \beta=\text { beach slope, and } \\
& k_{\mathrm{B}}=\text { Boussinesq wave number, expressed as } \\
& k_{\mathrm{B}}=(n \omega / 2 K D)^{1 / 2}
\end{aligned}
$$

where

$$
\begin{aligned}
n & =\text { porosity } \\
\omega & =\text { angular velocity of the tide, and } \\
K & =\text { hydraulic conductivity. }
\end{aligned}
$$

The beach slope is presumed to annually average about 2 degrees, on the basis of an analysis of the effects of offroad vehicles on beach slope (Anders and Leatherman, 1987) and from examination of selected beach profiles collected under the Atlantic Coast of New York Monitoring Program (New York Sea Grant, 2007) on Fire Island. The porosity and hydraulic conductivity of coarse-grained beach-face sediments are estimated to be about 0.3 and $60 \mathrm{~m} / \mathrm{d}$, respectively. The angular velocity of the tide is calculated to be 0.5059 radians per hour, on the basis of a tidal period of 12.42 hours. The resulting estimate of water-table overheight for the case of a sloping beach face is about $0.11 \mathrm{~m}$ - the same value estimated for a vertical beach face.

Thus, the sum of additive water-table overheight estimates for cases of a vertical and sloping beach face is roughly $0.22 \mathrm{~m}$ for the Atlantic Ocean shore of Fire Island. However, these terms do not account for the development of a seepage face that forms on all but the steepest beaches as the water table decouples from the falling tide (Turner and others, 1996). This development results in a further increase in the water-table overheight, but solutions to predict the amount of this increase do not appear to be readily available (Turner and others, 1996; Nielsen, 1999). Therefore, the total estimate of water-table overheight resulting from tidal pumping that was calculated in this study probably can be considered a conservative approximation. In combination with the maximum wave setup at the shore, the total water-table overheight resulting from wave setup and tidal pumping along the Atlantic Ocean shore of Fire Island is estimated to be about $0.66 \mathrm{~m}$.

\section{Freshwater-Saltwater Interface}

The freshwater flow system of Fire Island is bounded in the subsurface by the freshwater-saltwater interface. The position of the freshwater-saltwater interface was estimated from filter-press core samples and borehole 
electromagnetic-induction logs. Filter-press core samples were collected by a method adapted from Lusczynski (1961). Samples with a salinity of approximately 0.4 part per thousand - corresponding to a chloride concentration of about $250 \mathrm{mg} / \mathrm{L}$ - were considered to indicate the depth at which the freshwater-saltwater transition zone begins. Data from filterpress core samples and electromagnetic-induction logs were correlated to identify the position of the freshwater-saltwater interface (figs. 5 and 8).

\section{Directions of Groundwater Flow}

The movement of fresh groundwater on Fire Island is controlled by the distribution of hydraulic head, which in turn is controlled by the boundary conditions and hydraulic properties of the freshwater flow system. Groundwater levels on Fire Island vary in response to storm tides and other fluctuations in coastal water levels, to seasonal or annual variations in recharge from precipitation, and, to a much lesser extent, to changes in water use. Long-term (1950-1976) water-level records from wells in the isolated freshwater flow systems of eastern Long Island (Nemickas and Koszalka, 1982; McNew-Cartwright, 1996; Simmons, 1986) indicate the water-table altitude generally declines from May through early October, when recharge is smallest and water use is greatest, and generally rises from the end of October through the end of April, when recharge is greatest and water use is smallest (Schubert, 1998).

Synoptic water-level measurements were made at 35 observation wells during October 31-November 1, 2005, and March 28-29 and October 3-4, 2006 (appendix 1). Water levels measured during October 31-November 1, 2005, were used to depict the distribution of hydraulic head on Fire Island shown in figure 8 . The water levels were measured in this study within 1 hour of the predicted time of low tide to minimize spatial differences in hydraulic head caused by tidal fluctuations. In addition, one well in each of four local study areas was instrumented with a continuous water-level recorder to document groundwater fluctuations caused by tides, natural recharge, and other factors such as wave height and wastewater disposal. Water-level records of 18-month duration were collected from one well each in the vicinity of Kismet (S125986) and the National Wilderness (S125364) during October 2005-April 2007 (figs. 15A and D). Records of 3-month duration were collected sequentially from six wells each in the vicinities of Robbins Rest (S125994, S125982, S125998, S125997, S125996, and S126000) and Watch Hill (S125380, S125383, S125381, S125382, S125387, and S125990) during the same 18-month period (figs. 15B and C). Coastal water levels also were monitored continuously during this period at the nearby USGS tide-stage gaging station on Reynolds Channel at Point Lookout, N.Y. (figs. 15A-D)

A map of the synoptic water-level measurements made at 35 wells during October 31-November 1, 2005, is shown in figure 4 . The water levels generally increased with proximity to the ocean shore; the highest water levels were at wells nearest the ocean or those just inland. Water levels in inland wells also increased with barrier-island width. The pattern was similar among synoptic water-level measurements made at the 35 wells during March 28-29 and October 3-4, 2006 (appendix 1). These results indicate the groundwater divide of Fire Island is skewed strongly toward the ocean shore, apparently because of the combined effects of wave setup and tidal pumping and the resulting water-table overheight along this shore. Water levels measured continuously during October 2005-April 2007 at the single wells in Kismet and the National Wilderness (figs. 15A and D, respectively) indicate that fluctuations caused by storm tides and other short-term factors generally equal or exceed any seasonal or longer-term fluctuations. The continuous water levels collected during this same period at 3-month intervals from six wells each in Robbins Rest and Watch Hill (figs. 15B and C, respectively) appear to show a similar pattern, although the short-term fluctuations at inland wells (S125997, S125998, S125381, and S125382, for example) are somewhat damped.

\section{Nitrogen Concentrations}

Freshwater entering the water table through infiltration of precipitation, and wastewater disposal in unsewered areas, contains nutrients in concentrations that vary spatially and temporally. The concentration of a solute, such as nitrogen, in the aquifer depends on the location and rate at which it is introduced and the flow paths and traveltime of water in which it moves. Nitrogen concentrations also can be altered by physical processes such as dilution and dispersion and biogeochemical processes such as denitrification. The primary form of nitrogen in natural waters - nitrate, ammonia, or organic nitrogen - is controlled by the $\mathrm{pH}$ and redox conditions in the water (Hem, 1985). Nitrate is an oxidized form of nitrogen that can be transported conservatively in groundwater, whereas ammonia is a reduced form that strongly sorbs to aquifer sediments (Hem, 1985).

Water samples were collected by the USGS during October 2005 from 35 observation wells to determine the spatial distribution of nutrients from wastewater and natural sources; analytes provided by the USGS National Water Quality Laboratory in Denver, Colo., included dissolved inorganic nitrogen (ammonia, nitrite plus nitrate, and nitrite) and phosphorus (orthophosphate). A subset of four wells-one from each local study area-was resampled during March 2006 and August-September 2006 with an additional 21 wells to assess the seasonal variability of nutrient concentrations. Dissolved oxygen, $\mathrm{pH}$, specific conductance, water temperature, and oxidation reduction potential were measured during well evacuation.

A map showing the distribution of total nitrogen (TN) concentrations, which were computed by summing the concentrations of ammonia and nitrite plus nitrate for the 35 wells sampled during October 2005 (appendix 2), is provided in figure 16; seasonal TN concentrations for the 4 wells resampled during March and August-September 

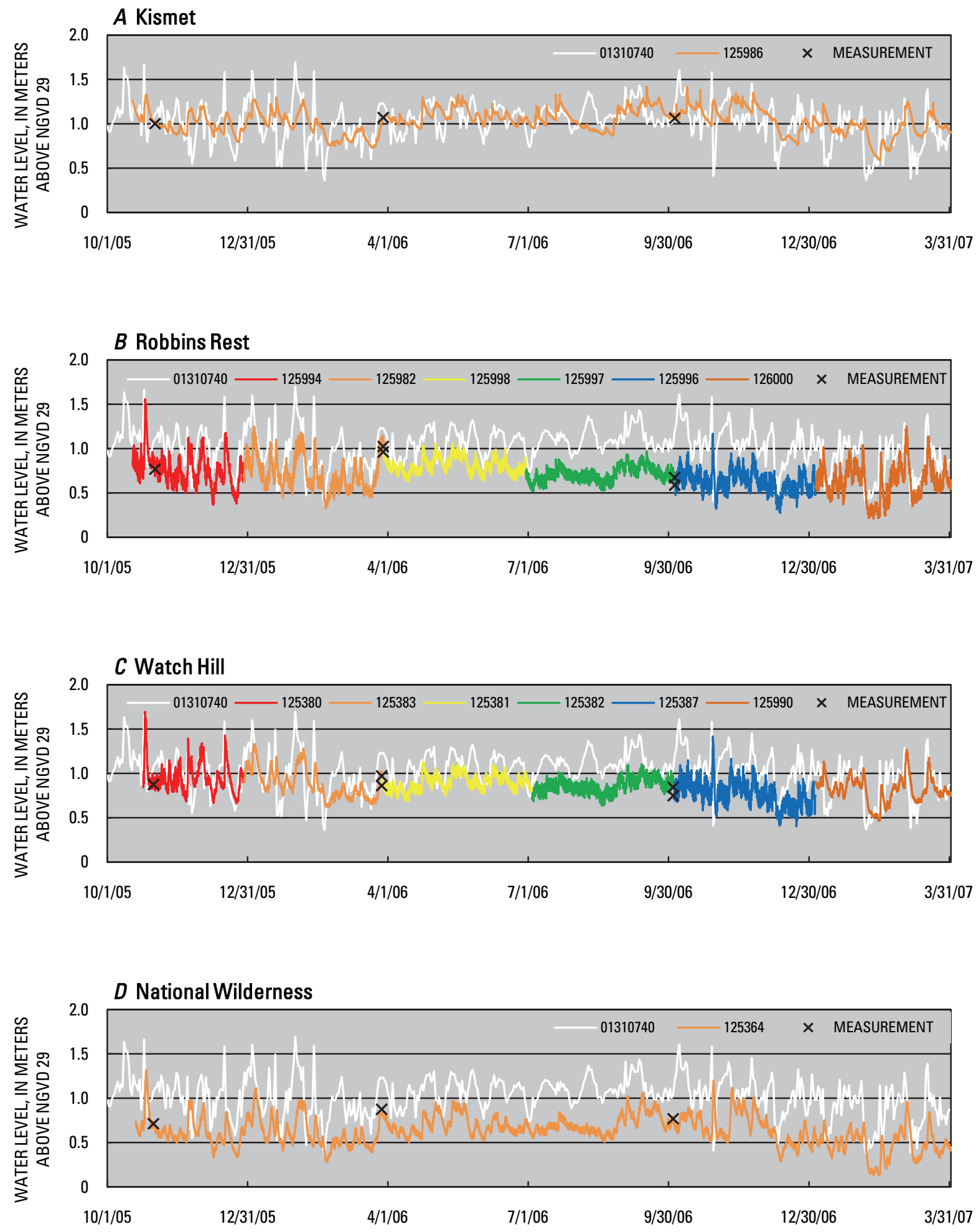

Figure 15. Continuous water-level records and synoptic water-level measurements at selected wells on Fire Island, and daily higher high water values at tide-stage gaging station 01310740 Reynolds Channel at Point Lookout, N.Y., during October 2005-April 2007, Long Island, N.Y. (Well locations are shown in figure 4. Station location is shown in figure 1. Well number is assigned by New York State Department of Environmental Conservation. Prefix "S" denoting Suffolk County is omitted. NGVD 29, National Geodetic Vertical Datum of 1929) 
2006 are shown in figure 17. The TN concentrations from most wells in undeveloped areas of the park near Kismet and Robbins Rest (figs. 16A and B, respectively) generally were comparable to those in the same areas of Watch Hill and the National Wilderness (figs. 16C and D, respectively). However, TN concentrations from four wells downgradient from the two communities (S126753, S125370, S125994, and S126000; figs. 16A and B) and those near the Watch Hill leach field were elevated above background (natural) levels observed in the undeveloped park areas by a factor of 10 or more. The pattern was similar among the 25 wells resampled during August-September 2006 (appendix 2). These results suggest that $\mathrm{TN}$ concentrations within the communities are comparable to those calculated by Monti and Scorca (2003) for similar settings along coastal areas of the southern Long Island mainland (Schubert, 2007). The highest TN concentrations - up to $10 \mathrm{mg} / \mathrm{L}$ - were measured immediately downgradient from the Watch Hill leach field; the lowestless than $0.1 \mathrm{mg} / \mathrm{L}$ - were within the National Wilderness. TN concentrations resampled from four wells during March and August-September 2006 (fig. 17) varied somewhat through time, although no consistent pattern emerged.

The primary form of nitrogen from wells near Kismet and Robbins Rest varied between ammonia and nitrate (appendix 2). Ammonia was the primary form in the vicinity of Watch Hill, whereas nitrate predominated within the National Wilderness. The presence in the shallow subsurface of peat containing organic carbon likely favors the denitrification of nitrate to nitrogen gas, although the small transport distances and attendant traveltime to receptors could limit this and other processes of attenuation. Use of the TN concentrations to calculate nitrogen loads may, therefore, result in a worst-case estimate of mass-loading rates; as such, it also would favor strategies to ensure protection of park natural resources.

\section{Analysis of the Shallow Groundwater Flow System at Fire Island National Seashore}

The analysis of the shallow groundwater flow system at FIIS entailed the development of a three-dimensional model of the shallow aquifer system and adjacent marine surface waters to simulate groundwater flow patterns and rates. Nitrogen loads from the shallow aquifer system were calculated from measured TN concentrations and simulated groundwater discharges to back-barrier estuaries and the ocean.

\section{Development of Flow Model}

Development of the flow model included the construction of the model grid and the assignment of appropriate boundary conditions and aquifer properties. The model was calibrated to observed water levels. The variable-density groundwater flow model SEAWAT-2000 (Langevin and others, 2003) was used in the analysis. SEAWAT outputs hydraulic heads that are referenced to the simulated density (a function of salinity) at a given location and time.

\section{Model Grid}

The model grid encompasses the full breadth of Fire Island (as mapped by Klopfer and others, 2002) and consists of 72 rows, 1,008 columns, and 12 layers. The grid has a uniform horizontal discretization of $50 \mathrm{~m}$ along both rows and columns and is oriented 20.16 degrees counterclockwise from true north (fig. 18). The model represents the full thickness of the shallow aquifer system (fig. 19), extending from the water table to the base of the upper glacial aquifer (fig. 9); layer thicknesses vary from cell to cell and generally are based on the geometry of hydrogeologic units. Overall, the grid contains 870,912 cells, of which 367,752 are active and 503,160 are inactive.

Each of the Late Pleistocene and Holocene hydrogeologic units are represented in the model. Layer 1 represents three surficial Holocene units - upper outwash, peat deposits, and barrier and shelf sands - in onshore areas (fig. 20); surfacewater bodies also are represented in layer 1. Layer 2 represents an underlying lens of peat deposits in onshore areas, and five surficial Holocene units-lagoonal deposits, estuarine mud, seagrass beds, peat deposits, and barrier and shelf sands - in back-bay and ocean areas (fig. 21). Layers 3-5 represent lagoonal deposits, except along the Long Island mainland, where these layers represent the upper outwash of the upper glacial aquifer (fig. 22). Layers 6-8 represent upper outwash. Layer 9 represents the " 20 -foot" clay, except in areas where this unit is absent; in these areas, layer 9 represents the lower outwash of the upper glacial aquifer (fig. 23). Layers 10 and 11 represent the lower outwash, and layer 12 represents the fine-grained, basal part of this unit.

\section{Boundary Conditions}

The boundary conditions specified in the flow model coincide with the hydrologic boundaries of the freshwater flow system under present (2005) conditions. These hydrologic boundaries are assumed to be constant through time and are used to simulate groundwater flow for steady-state, average annual conditions.

A no-flow condition is specified at the lateral boundary between active and inactive model zones in all layers (fig. 18). This boundary condition also applies at the bottom of the lowermost model layer (12), which represents the base of the upper glacial aquifer (fig. 9). Low-permeability units beneath this aquifer - the Gardiners Clay and Monmouth greensandconstitute confining units that hydraulically isolate the upper glacial aquifer from the underlying Magothy aquifer (Scorca and others, 1995). 
$73^{\circ} 12^{\prime} 15^{\prime \prime}$

$73^{\circ} 12$

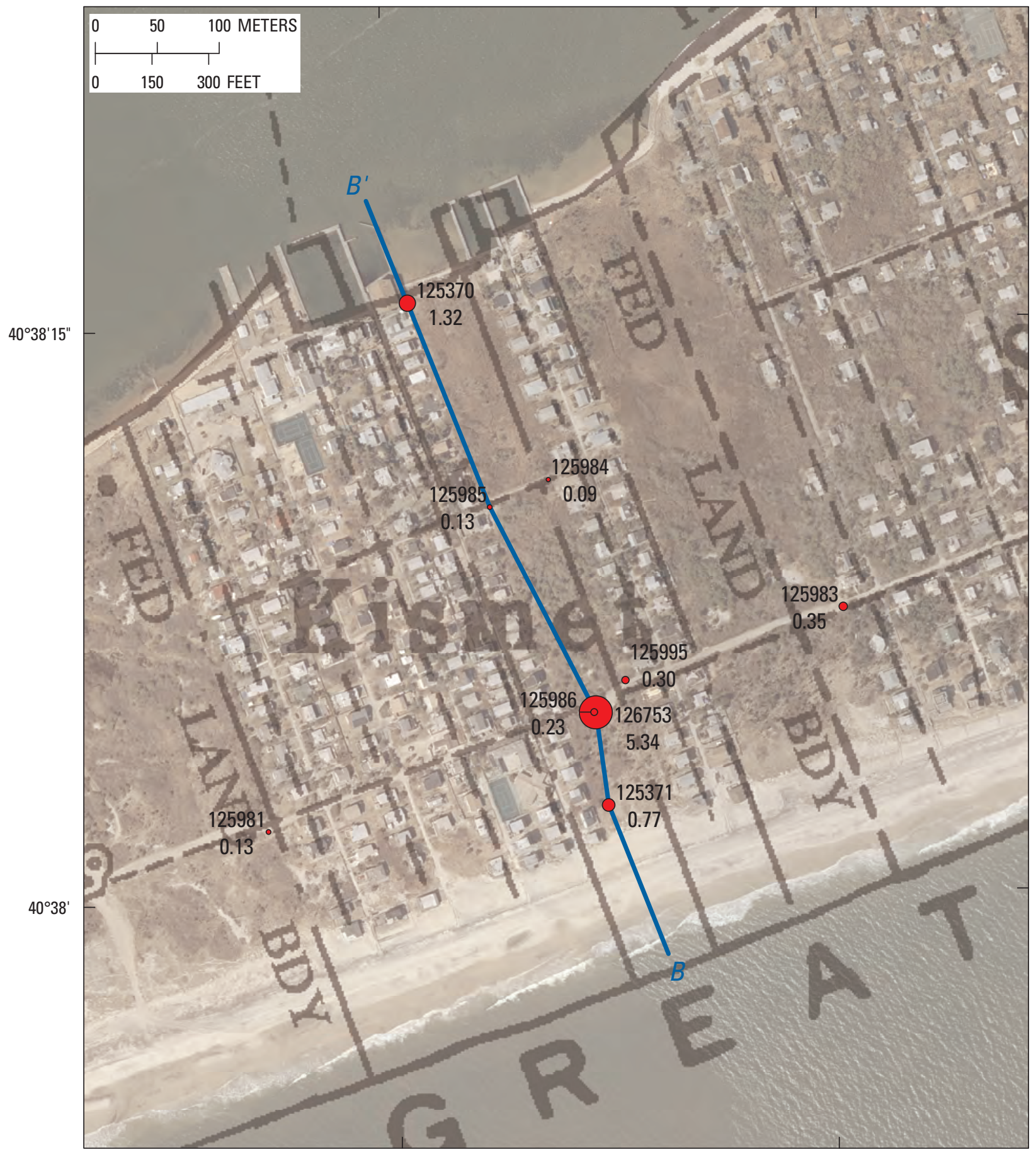

Base from New York State Department of Transportation planimetric quadrangles, 1991, 1:24,000; Universal Transverse Mercator projection, NAD 83, Zone 18

\section{EXPLANATION}

$B-B^{\prime}$ Trace of Hydrogeologic Section--Shows location of vertical section shown in figure 8A.

Point of Observation-Well Sample--Size is proportional to total nitrogen concentration. 125370 Upper number is identifier. Lower number is total nitrogen concentration, in $\mathrm{mg} / \mathrm{L}$.

Figure 16. Total nitrogen concentrations at 35 wells sampled during October 2005 on Fire Island, Suffolk County, N.Y. (Well number is assigned by New York State Department of Environmental Conservation. Prefix "S" denoting Suffolk County is omitted. mg/L, milligrams per liter; NAD 83, North American Datum of 1983) 
$73^{\circ} 10^{\prime}$

$73^{\circ} 9^{\prime} 45^{\prime \prime}$

$\begin{array}{ccc}0 & 50 & 100 \text { METERS } \\ & \mid & \mid \\ 0 & 150 & 300 \text { FEET }\end{array}$

$40^{\circ} 38^{\prime} 45^{\prime \prime}$

$40^{\circ} 38^{\prime} 30^{\prime \prime}$
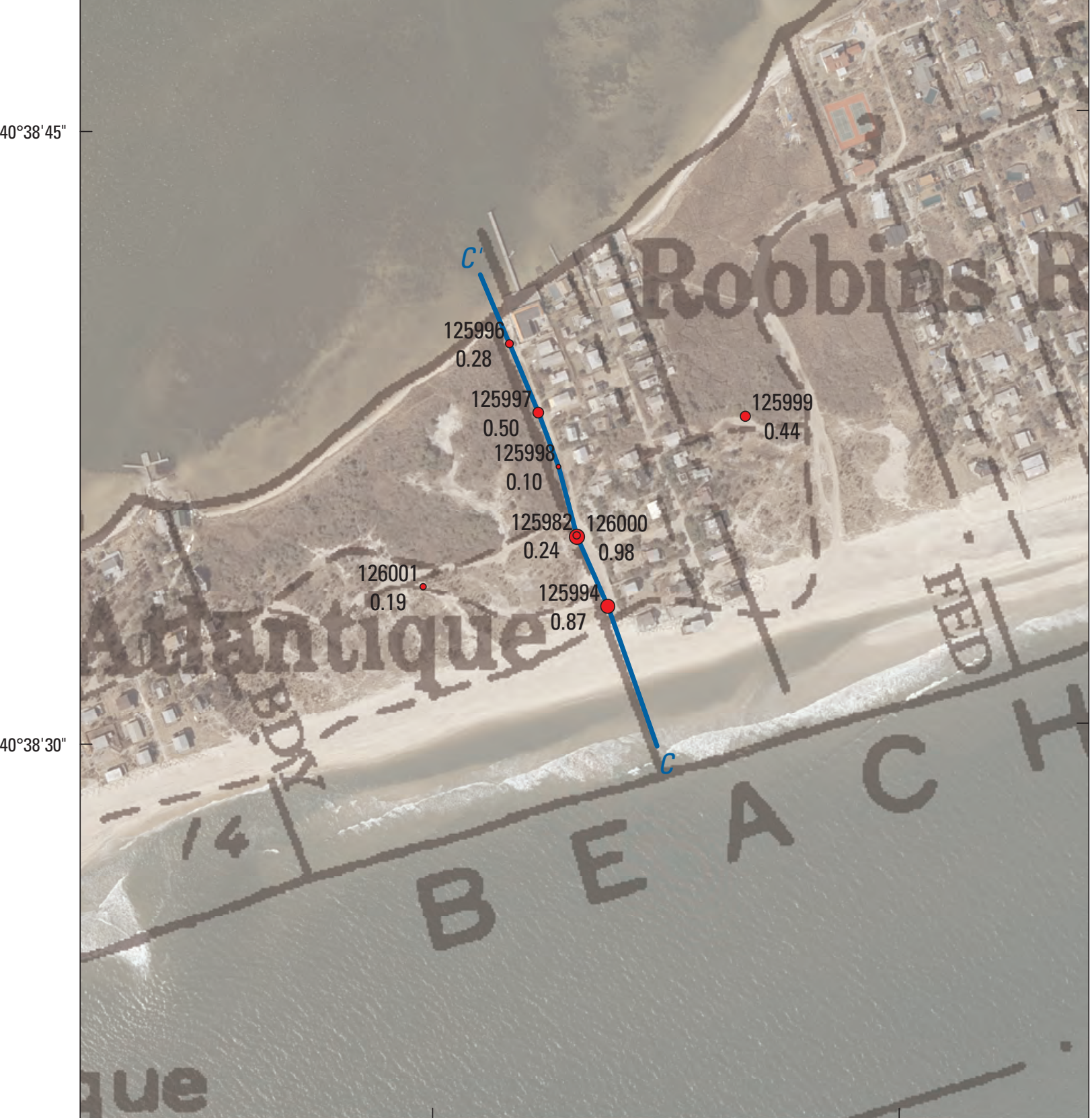

Base from New York State Department of Transportation planimetric quadrangles, 1991, 1:24,000; Universal Transverse Mercator projection, NAD 83, Zone 18

\section{EXPLANATION}

$C-C^{\prime}$ Trace of Hydrogeologic Section--Shows location of vertical section shown in figure 8B.

Point of Observation-Well Sample--Size is proportional to total nitrogen concentration.

125996 Upper number is identifier.

0.28

Lower number is total nitrogen concentration, in $\mathrm{mg} / \mathrm{L}$.

Figure 16. Total nitrogen concentrations at 35 wells sampled during October 2005 on Fire Island, Suffolk County, N.Y. (Well number is assigned by New York State Department of Environmental Conservation. Prefix "S" denoting Suffolk County is omitted. mg/L, milligrams per liter; NAD 83, North American Datum of 1983)—Continued 


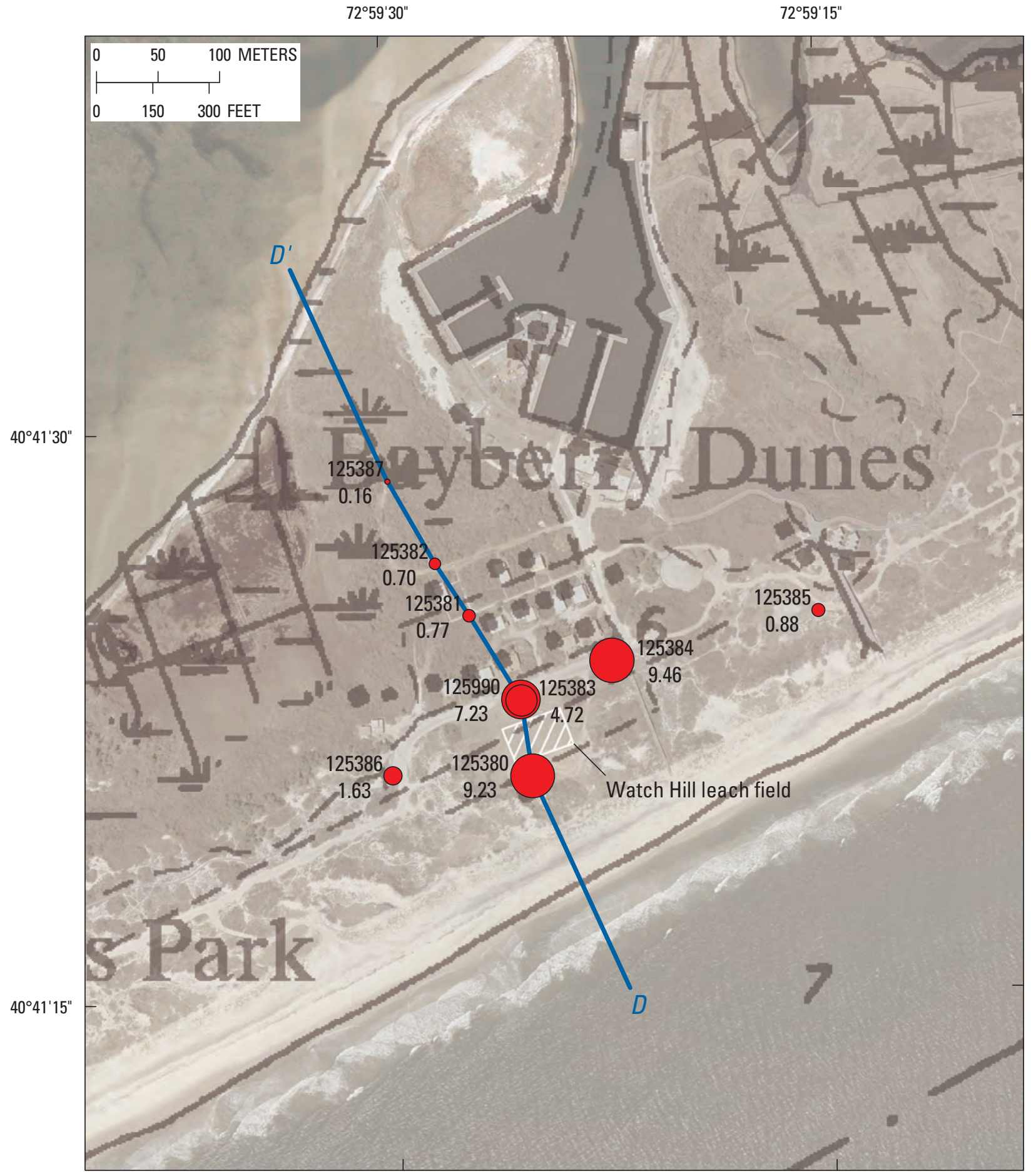

Base from New York State Department of Transportation planimetric quadrangles, 1991, 1:24,000; Universal Transverse Mercator projection, NAD 83, Zone 18

\section{EXPLANATION}

$D-D^{\prime}$ Trace of Hydrogeologic Section--Shows location of vertical section shown in figure 8C.

Point of Observation-Well Sample--Size is proportional to total nitrogen concentration. 125387 Upper number is identifier.

0.16 Lower number is total nitrogen concentration, in $\mathrm{mg} / \mathrm{L}$.

Figure 16. Total nitrogen concentrations at 35 wells sampled during October 2005 on Fire Island, Suffolk County, N.Y. (Well number is assigned by New York State Department of Environmental Conservation. Prefix "S" denoting Suffolk County is omitted. mg/L, milligrams per liter; NAD 83, North American Datum of 1983)—Continued 


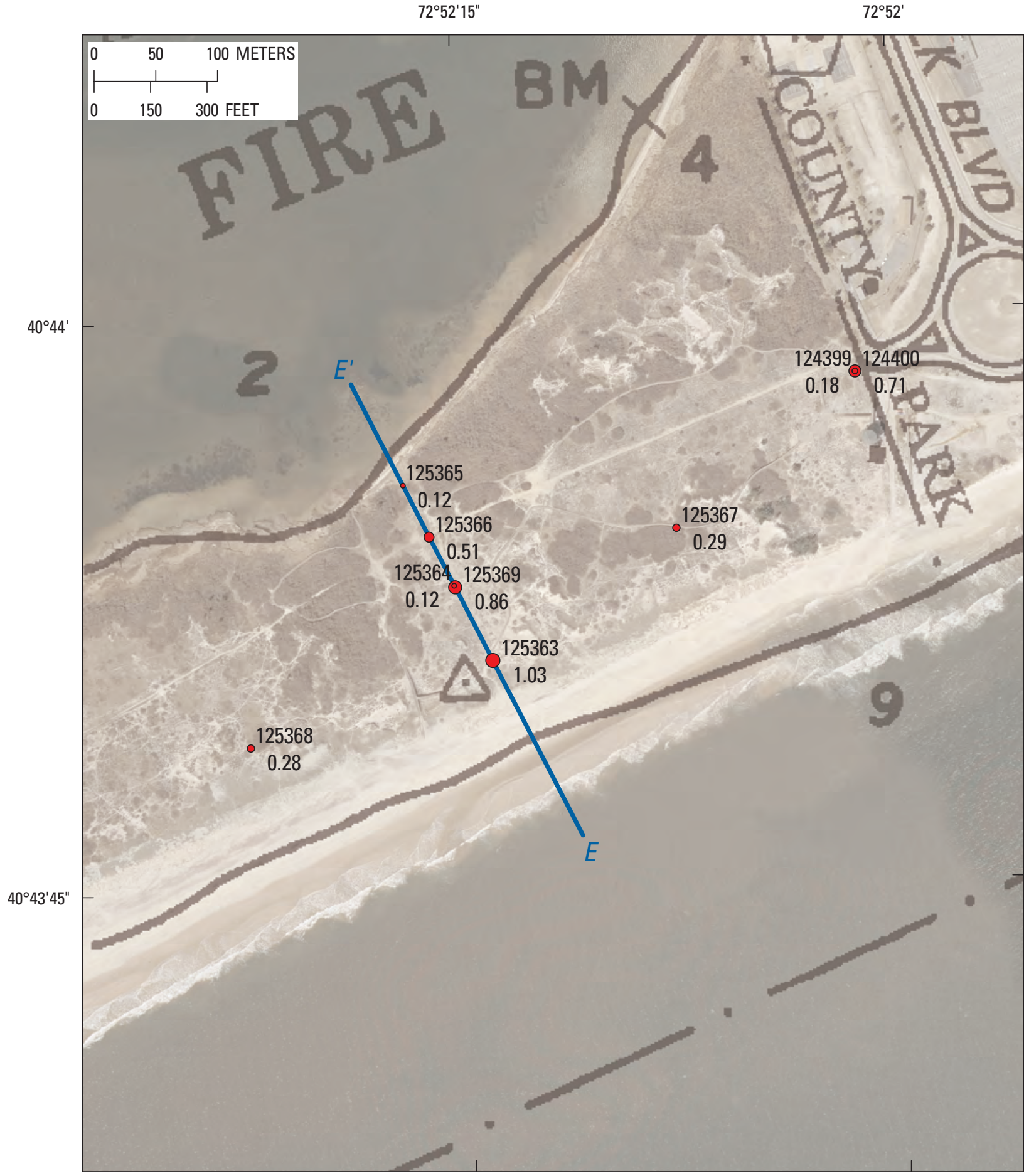

Base from New York State Department of Transportation planimetric quadrangles, 1991, 1:24,000; Universal Transverse Mercator projection, NAD 83, Zone 18

\section{EXPLANATION}

$E-E^{\prime}$ Trace of Hydrogeologic Section--Shows location of vertical section shown in figure 8D.

Point of Observation-Well Sample--Size is proportional to total nitrogen concentration. $125365 \bigcirc$ Upper number is identifier.

Lower number is total nitrogen concentration, in $\mathrm{mg} / \mathrm{L}$.

Figure 16. Total nitrogen concentrations at 35 wells sampled during October 2005 on Fire Island, Suffolk County, N.Y. (Well number is assigned by New York State Department of Environmental Conservation. Prefix "S" denoting Suffolk County is omitted. mg/L, milligrams per liter; NAD 83, North American Datum of 1983)—Continued 


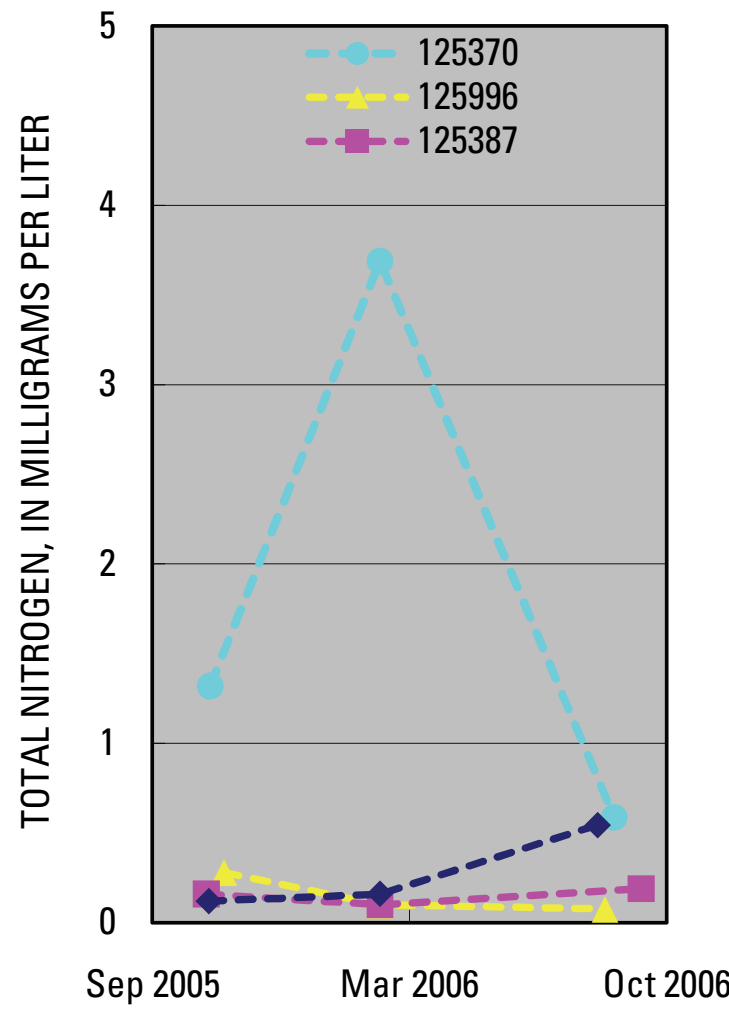

Figure 17. Total nitrogen concentrations at four wells sampled during October 2005 and March and August-September 2006 on Fire Island, Suffolk County, N.Y. (Well locations are shown in figure 6. Well number is assigned by New York State Department of Environmental Conservation. Prefix "S" denoting Suffolk County is omitted.)

Constant-head and constant-concentration boundaries were used in estuaries and the ocean to represent the flow of water between the shallow aquifer and marine surface waters (layer 1). Local MSL-NGVD 29 differences obtained or calculated for NOS tidal benchmarks and calculated using the VDatum program at supplementary ocean points were extrapolated throughout the back-bays and ocean to depict local MSL, to which the total water-table overheight resulting from wave setup and setdown and to tidal pumping was added (fig. 24). Long-term salinity-measurement records obtained from the SCDHS (R.M. Waters, Suffolk County Department of Health Services, written commun., 2006) and National Oceanographic Data Center (National Oceanographic Data Center, 2006) were extrapolated to provide a time-averaged depiction of salinity throughout the back-barrier estuaries and the ocean (fig. 25).

Offshore, water-surface altitudes (fig. 24) are lower in the ocean than in the back-barrier estuaries, where levels generally increase with distance from inlets. Along the immediate ocean shore, however, altitudes are higher than along the adjacent back-barrier estuary shore; altitudes are lowest near the breaker zone and underlying bar. Salinities (fig. 25) are higher in the ocean than in the back-barrier estuaries, where they generally decrease with distance from inlets.

Recharge from precipitation and the return flow of publicsupply water is represented as a specified-flux boundary at the water table (layer 1). Inland surface-water bodies (layer 1) are simulated as areas of high hydraulic conductivity $(15,000 \mathrm{~m} / \mathrm{d})$ and porosity (1).

Recharge from precipitation is simulated by five zones (fig. 26) that are numbered 1 through 5 and represent increasing rates of infiltration to the water table. The zones are assigned according to substrate, land cover, and altitude (table 8), the latter of which was used as a surrogate for water-table depth below land surface. Zone 1 consists of fresh surface-water bodies. Areas with developed features as mapped by Klopfer and others (2002) or where peat deposits constitute the surficial hydrogeologic unit are assigned by increasing land-surface altitude above NGVD 29 to zones 2 (less than $2 \mathrm{~m}$ ), 3 (between 2 and $4 \mathrm{~m}$ ), or 4 (greater than $4 \mathrm{~m}$ ). Vegetated areas associated with a loam substrate (Klopfer and others, 2002) are assigned by increasing land-surface altitude above NGVD 29 to zones 3 (less than $2 \mathrm{~m}$ ), 4 (between 2 and $4 \mathrm{~m}$ ), or 5 (greater than $4 \mathrm{~m}$ ). Areas associated with a sand substrate or sparse vegetation (Klopfer and others, 2002) are assigned by increasing land-surface altitude above NGVD 29 to zones 4 (less than $2 \mathrm{~m}$ ) or 5 (greater than or equal to $2 \mathrm{~m}$ ). The applied rates of recharge to the five model zones were calculated as follows:

1. 1938-96 mean annual precipitation at Patchogue minus 70 percent of long-term mean annual pan evaporation at Greenport (42 cm/yr);

2. 75 percent of $1938-96$ mean annual precipitation at Patchogue from October 15 through May 15 plus 55 percent of the difference between long-term mean annual pan evaporation at Mineola and Greenport (62 cm/yr); 
3. 90 percent of $1938-96$ mean annual precipitation at Patchogue from October 15 through May 15 plus 40 percent of the difference between long-term mean annual pan evaporation at Mineola and Greenport $(76 \mathrm{~cm} / \mathrm{yr})$;

4. 1938-96 mean annual precipitation at Patchogue minus 25 percent of long-term mean annual pan evaporation at Greenport ( $90 \mathrm{~cm} / \mathrm{yr})$; and

5. 1938-96 mean precipitation at Patchogue minus 10 percent of long-term mean annual pan evaporation at Greenport (109 cm/yr).

Recharge from the return flow of public-supply water is simulated by a series of rates (fig. 27) assigned according to water-supply system and return-flow component (distribution or waste, fig. 6). The rates of public-supply return flow within the unsewered Kismet and Fair Harbor-Summer Club distribution zones of the SCWA and Robert Moses State Park, Saltaire, Seaview, and Ocean Bay Park water-supply systems were calculated as 85 percent of the total 2005 pumpage for these systems divided by their service areas. In the sewered community of Ocean Beach, the rate of public-supply return flow was calculated as 15 percent of the total 2005 pumpage for this system divided by its service area. Rates of publicsupply return flow for the distribution and wastewater systems associated with four park facilities served by the SCWASmith Point County Park and the NPS Visitors Centers at Sailors Haven, Watch Hill, and the National Wildernessgenerally were calculated as 15 and 70 percent, respectively, of the total 2005 water supply to these facilities divided by the simulated areas of their corresponding systems. In the unsewered Point O'Woods-Fire Island Pines and Davis Park distribution zones of the SCWA, which supply water to the NPS facilities at Sailors Haven and Watch Hill, the rates of public-supply return flow generally were calculated as 85 percent of the total 2005 pumpage for these systems minus the NPS water supply, divided by the portions of their service areas that exclude the respective NPS systems.

The model does not simulate public-supply withdrawal because virtually all water-supply pumpage is from the underlying regional (unmodeled) aquifer system. Although there are limited private and NPS withdrawals in areas not served by the public water-supply systems, these typically are at low pumping rates and, therefore, not accounted for in the model.

\section{Model Calibration}

The flow model was calibrated through a quasi steadystate simulation of 2005 mean annual conditions, the results of which were then compared with corresponding measured values that were assumed to estimate long-term conditions. The model was considered calibrated when the difference between measured and simulated groundwater levels was minimized at wells in each of four local study areas and four (screened) hydrogeologic units. Steady-state groundwater levels were simulated during two consecutive 7,300-day (20-year) stress periods, the second of which was initiated with the results of the first; the same approach was followed to simulate steady-state salinities, except that the second stress period was 500 years. These procedures allowed model-calibration iterations to be run sufficiently quickly during simulation of steady-state groundwater levels, by only periodically performing the time-consuming simulation of steady-state salinities. Simulated groundwater levels were compared with water-level measurements at 35 observation wells during October 31-November 1, 2005 (figs. 4 and 8); simulated salinity concentrations were compared qualitatively with the positions of the freshwatersaltwater interface estimated at 21 wells during this study (figs. 5 and 8). Horizontal and vertical hydraulic conductivities that represent the water-transmitting properties of simulated hydrogeologic units were adjusted by trial and error to minimize the difference between measured and simulated groundwater levels.

The differences between measured and simulated water levels grouped by local study area and by hydrogeologic unit are summarized in tables 9 and 10, respectively. Mean differences by local study area ranged from a low of $-0.02 \mathrm{~m}$ at Kismet to a high of $0.03 \mathrm{~m}$ at the National Wilderness, and averaged $0.00 \mathrm{~m}$; by hydrogeologic unit, the mean differences ranged from a low of $-0.07 \mathrm{~m}$ in peat deposits to high values of $0.05 \mathrm{~m}$ in barrier island and shelf sands and in upper outwash, and averaged $0.00 \mathrm{~m}$. The measured and simulated water levels and vertical gradients at four observation-well pairs are shown in table 11 . The final simulated horizontal and vertical hydraulic conductivities for hydrogeologic units represented in the model are given in table 12 . A porosity of 0.3 was assumed for all unconsolidated sediments. Unconfined surficial sediments were assigned a specific yield of 0.15 ; values of specific storage in surficial units and in deeper confined units were assumed to be $2 \times 10^{-6}$ and $1 \times 10^{-5} \mathrm{ft}^{-1}$, respectively. Fresh surface-water bodies had a simulated specific storage and porosity of 1 . 

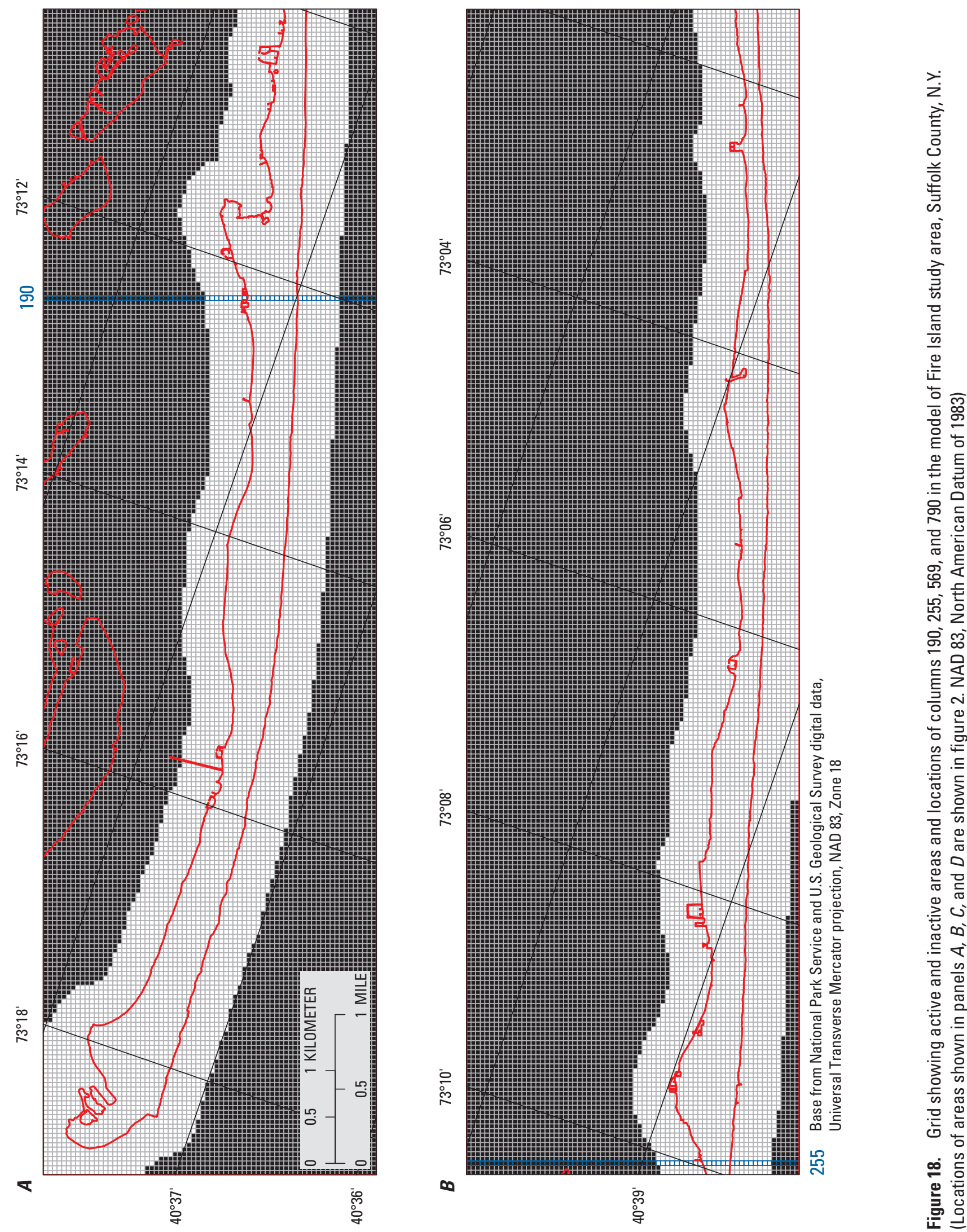

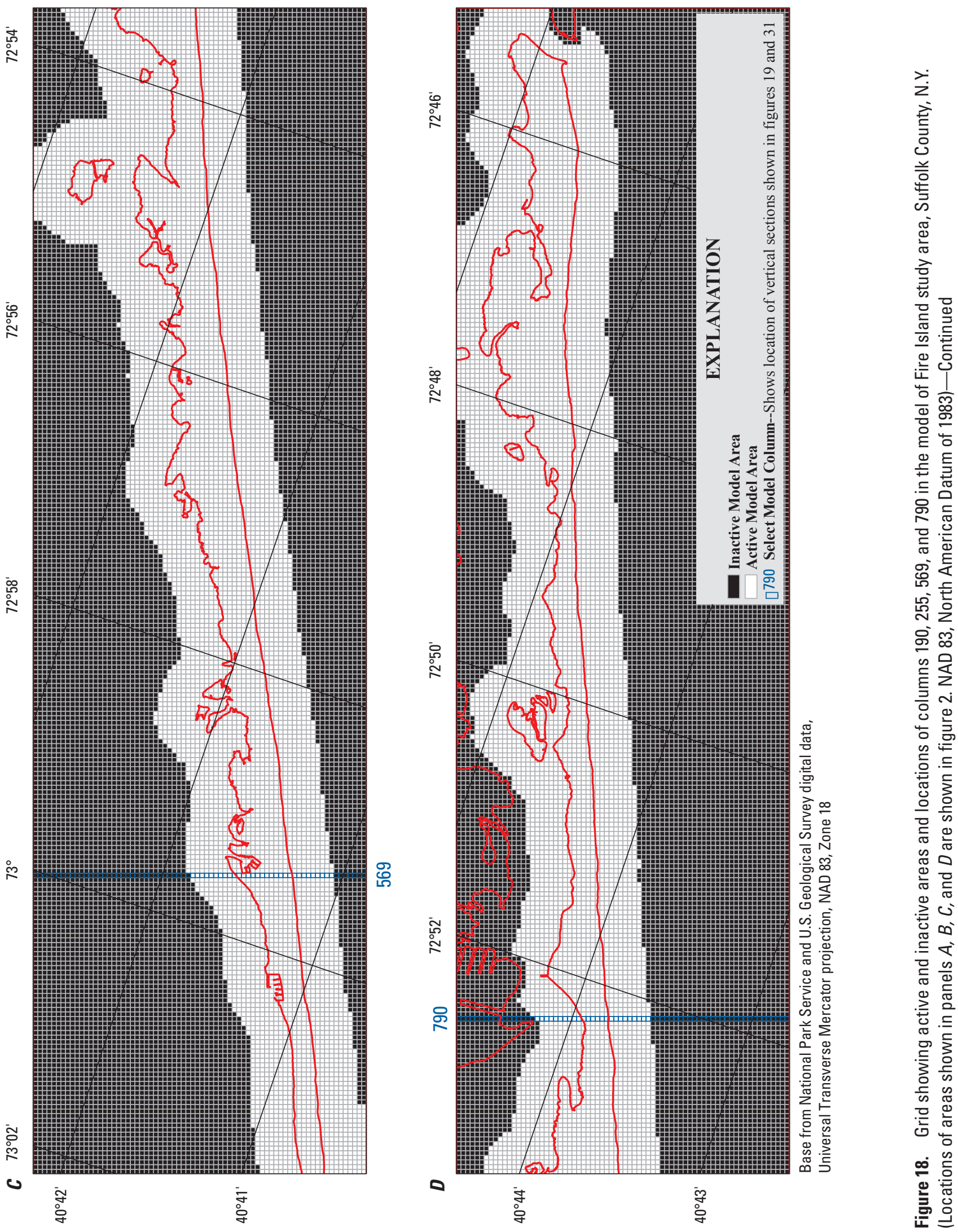


\section{A Column 190}

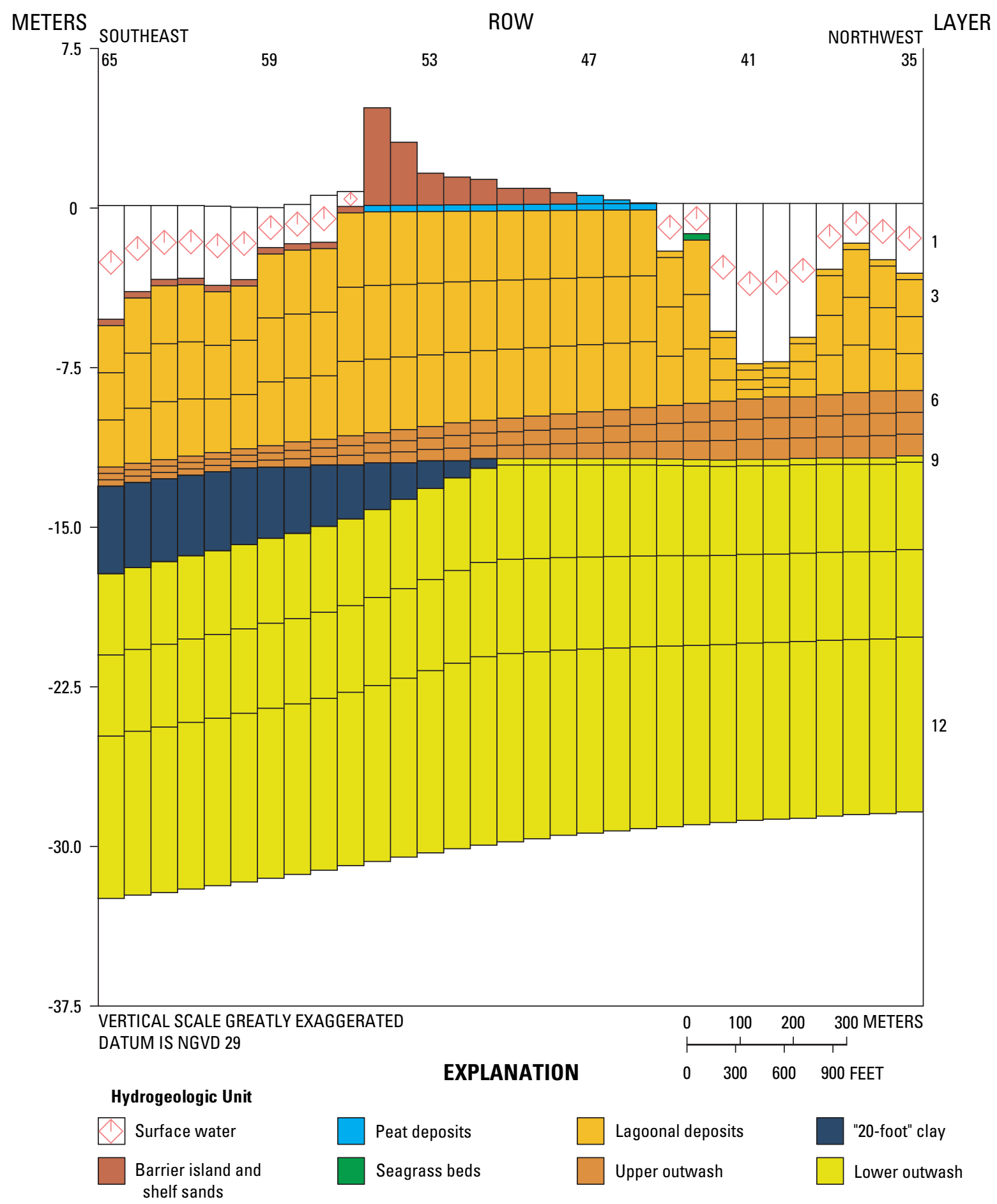

Figure 19. Modeled hydrogeologic units for active model cells along four selected columns in the Fire Island study area, Suffolk County, N.Y. (A) column 190, (B) column 255, (C) column 569, and (D) column 790. (Column locations are shown in figure 18. NGVD 29, National Geodetic Vertical Datum of 1929) 


\section{B Column 255}

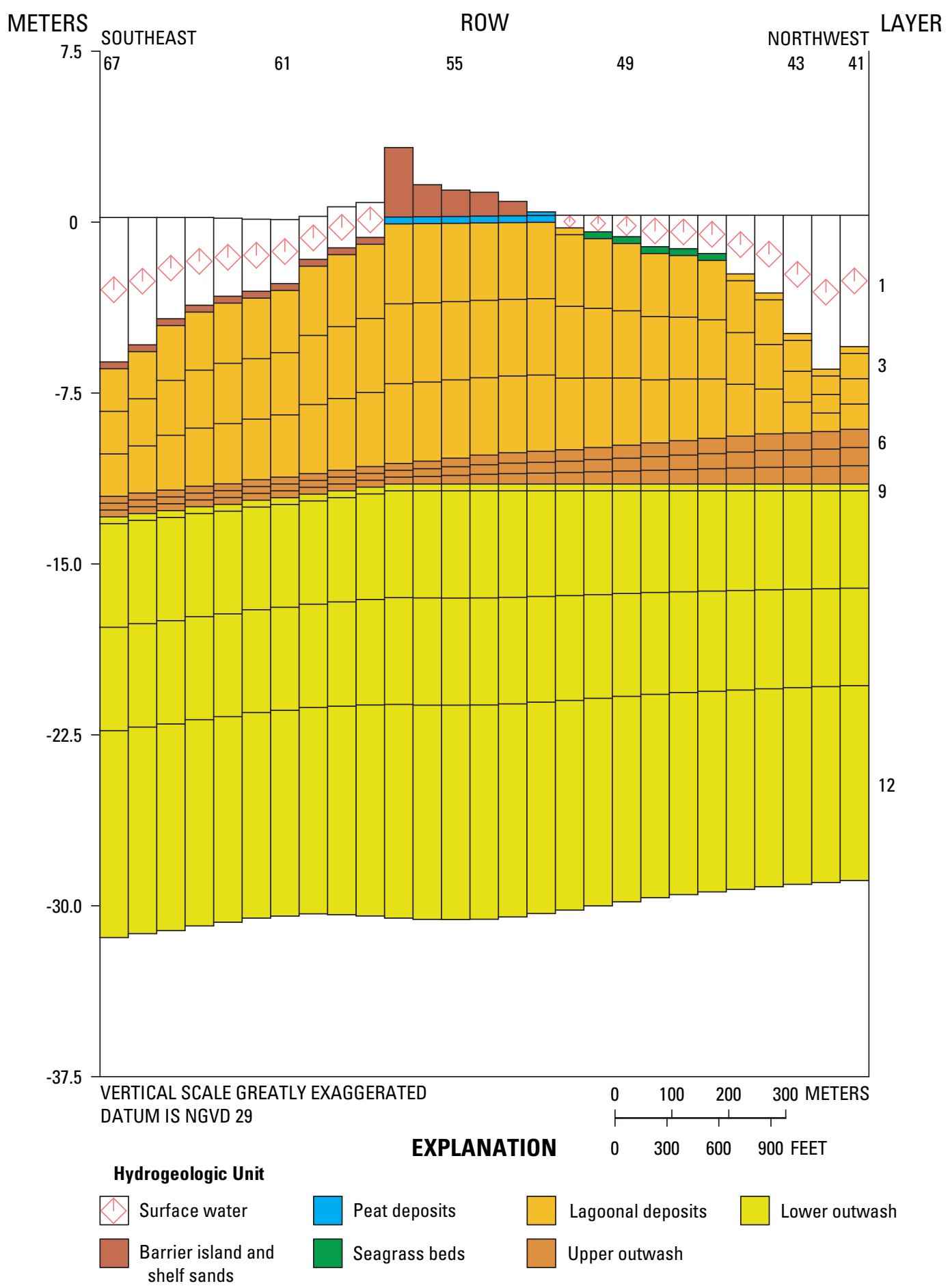

Figure 19. Modeled hydrogeologic units for active model cells along four selected columns in the Fire Island study area, Suffolk County, N.Y. (A) column 190, (B) column 255, (C) column 569, and (D) column 790. (Column locations are shown in figure 18. NGVD 29, National Geodetic Vertical Datum of 1929)—Continued 


\section{Column 569}

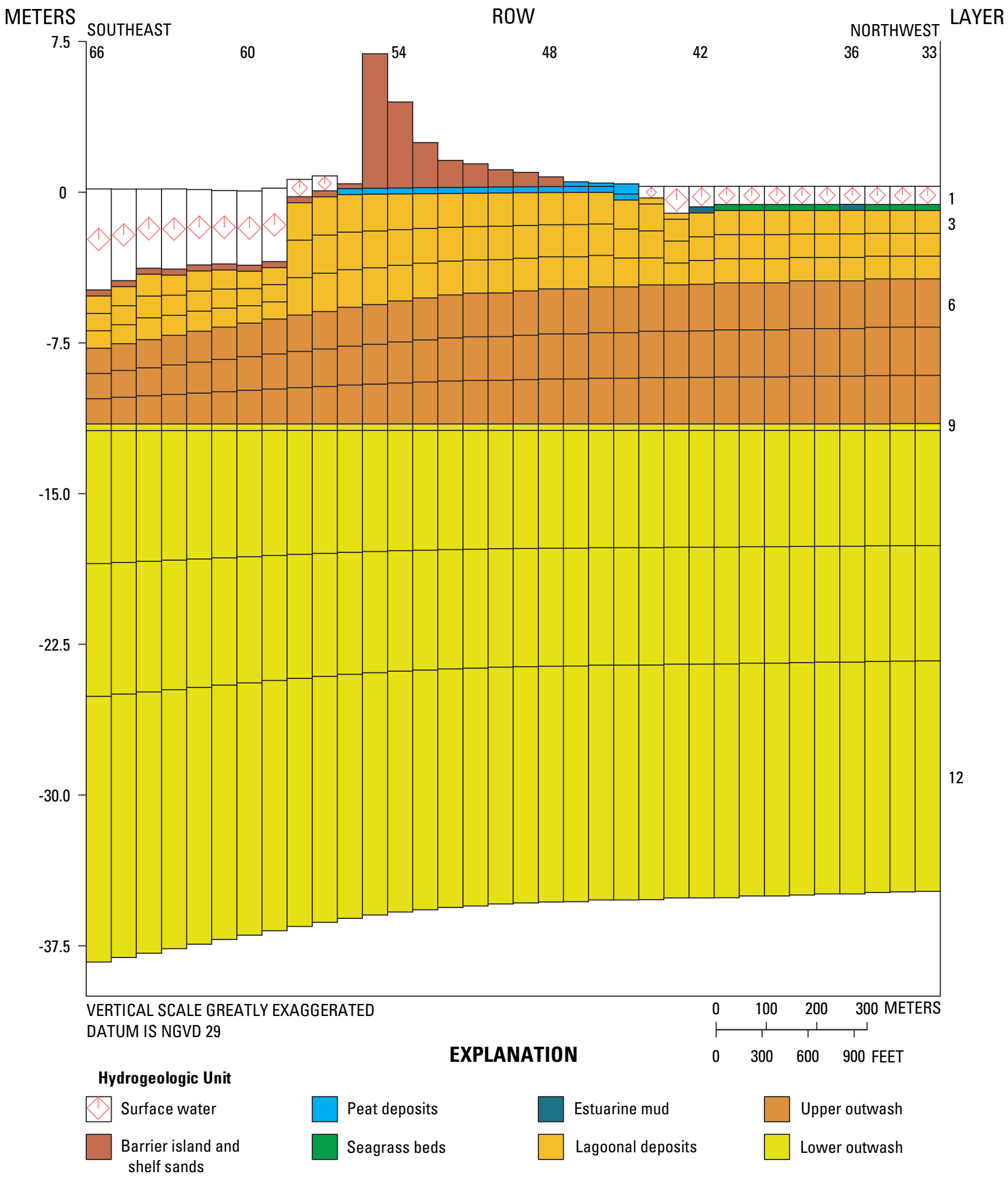

Figure 19. Modeled hydrogeologic units for active model cells along four selected columns in the Fire Island study area, Suffolk County, N.Y. (A) column 190, (B) column 255, (C) column 569, and (D) column 790. (Column locations are shown in figure 18. NGVD 29, National Geodetic Vertical Datum of 1929)_Continued 


\section{Column 790}

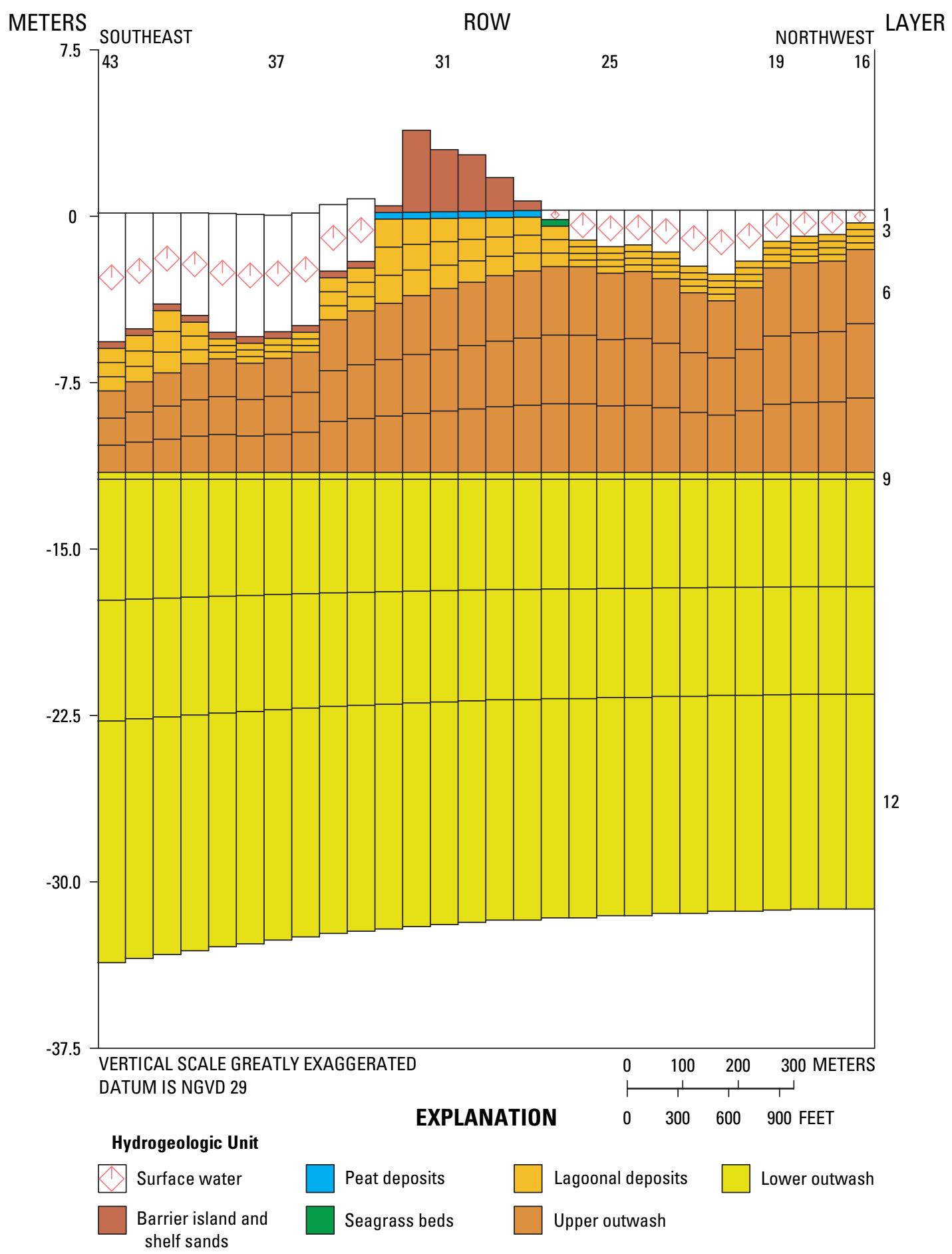

Figure 19. Modeled hydrogeologic units for active model cells along four selected columns in the Fire Island study area, Suffolk County, N.Y. (A) column 190, (B) column 255, (C) column 569, and (D) column 790. (Column locations are shown in figure 18. NGVD 29, National Geodetic Vertical Datum of 1929)—Continued 

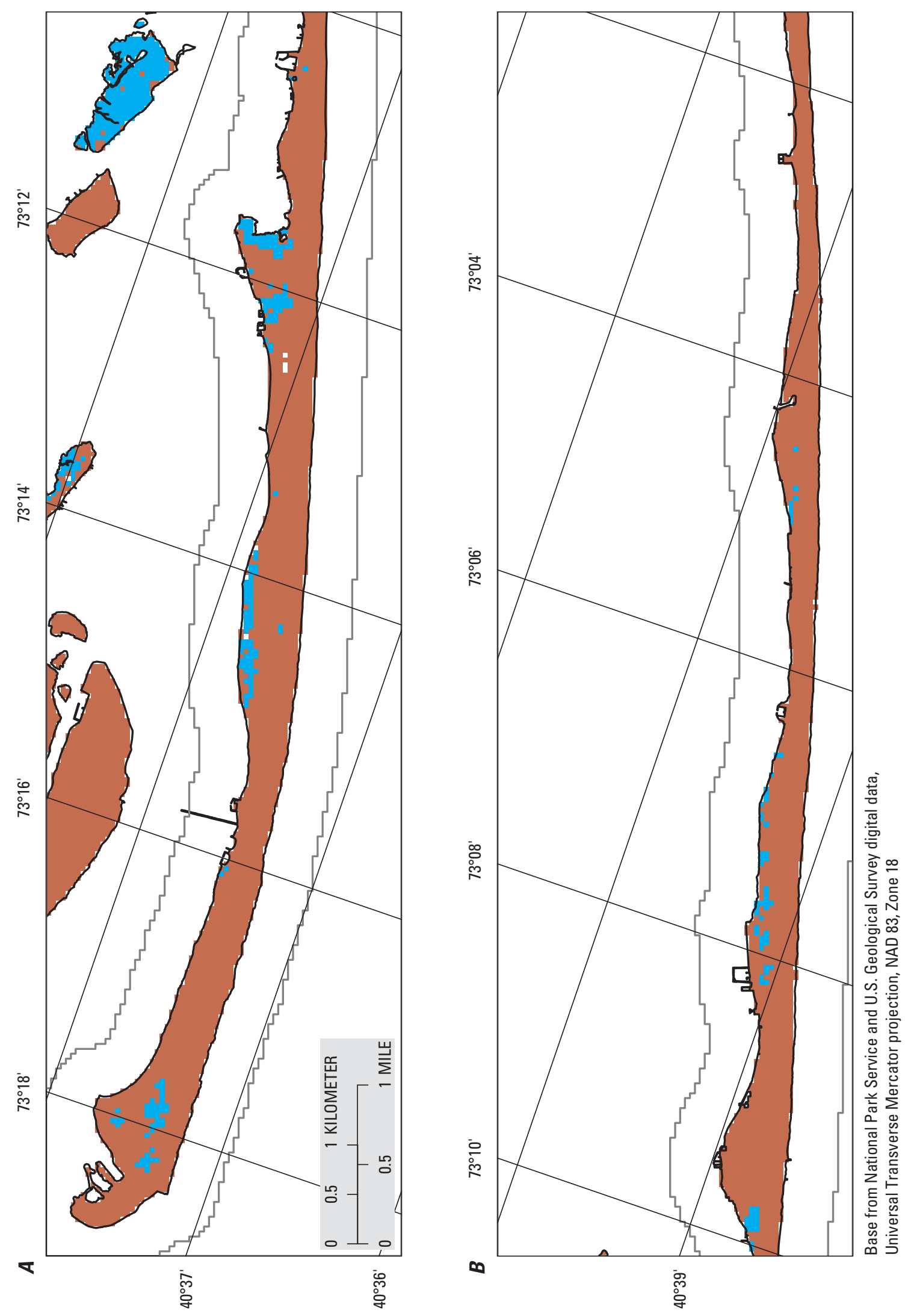

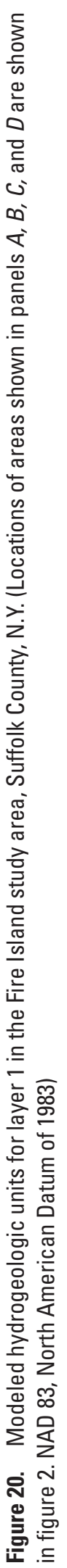



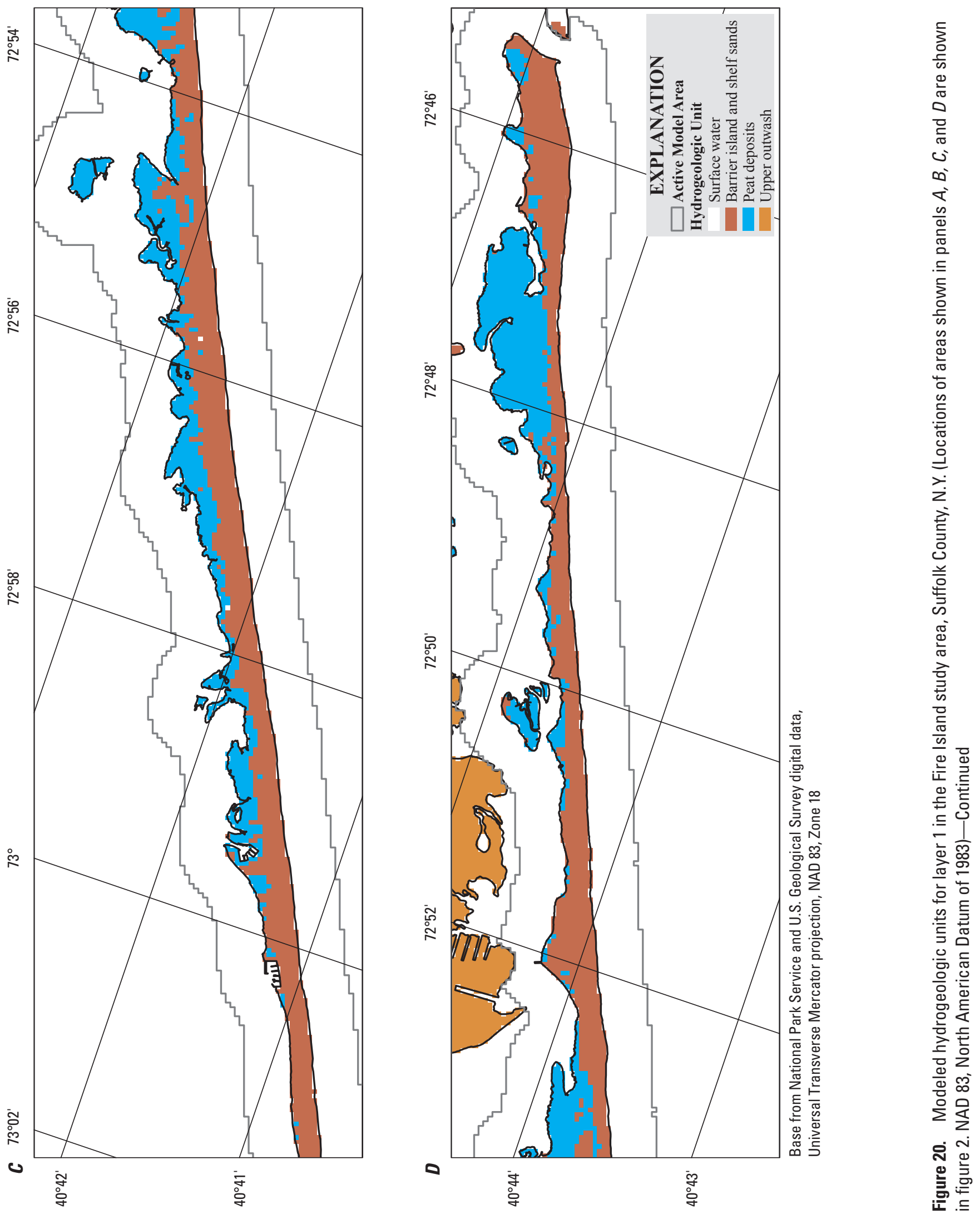

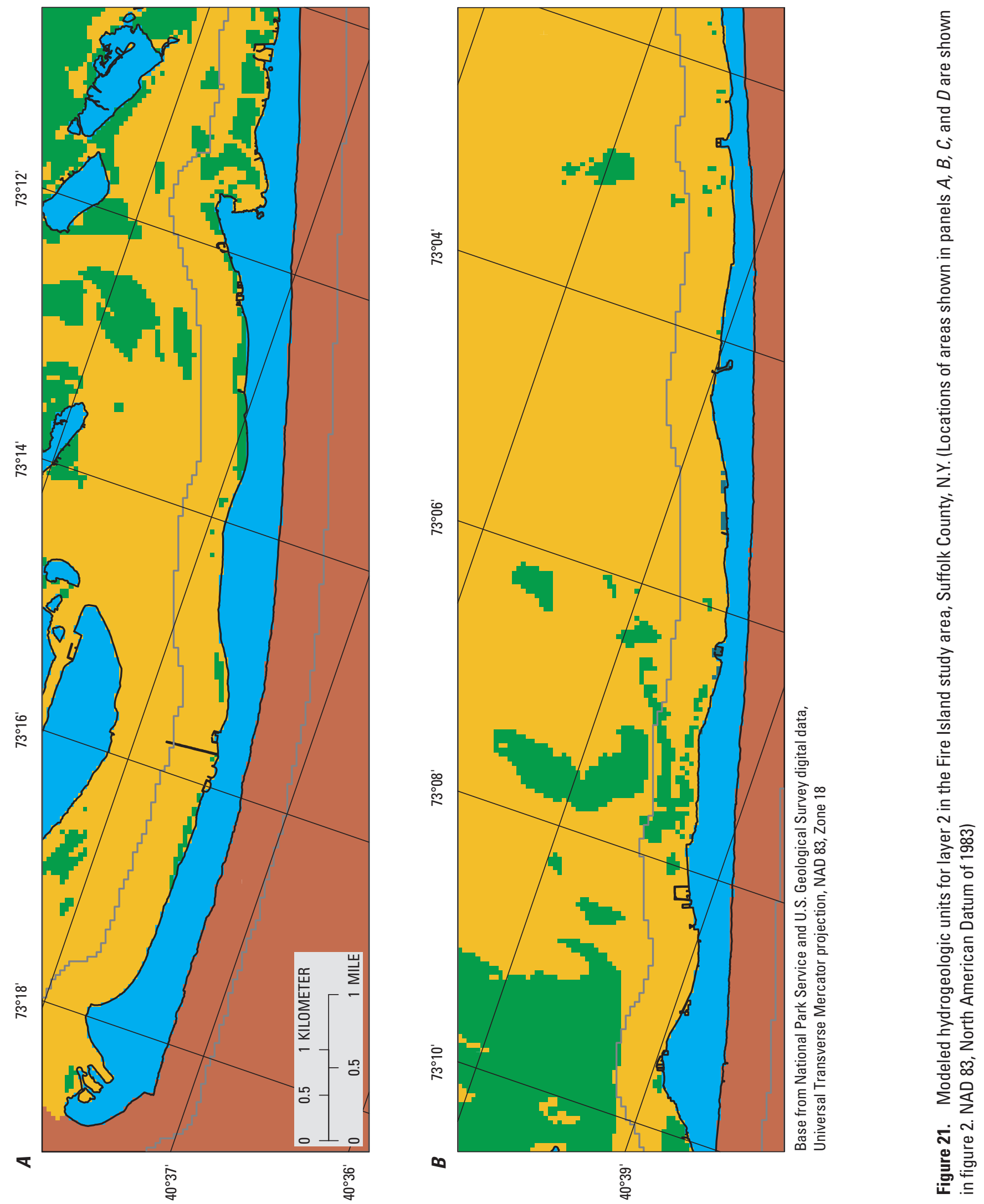

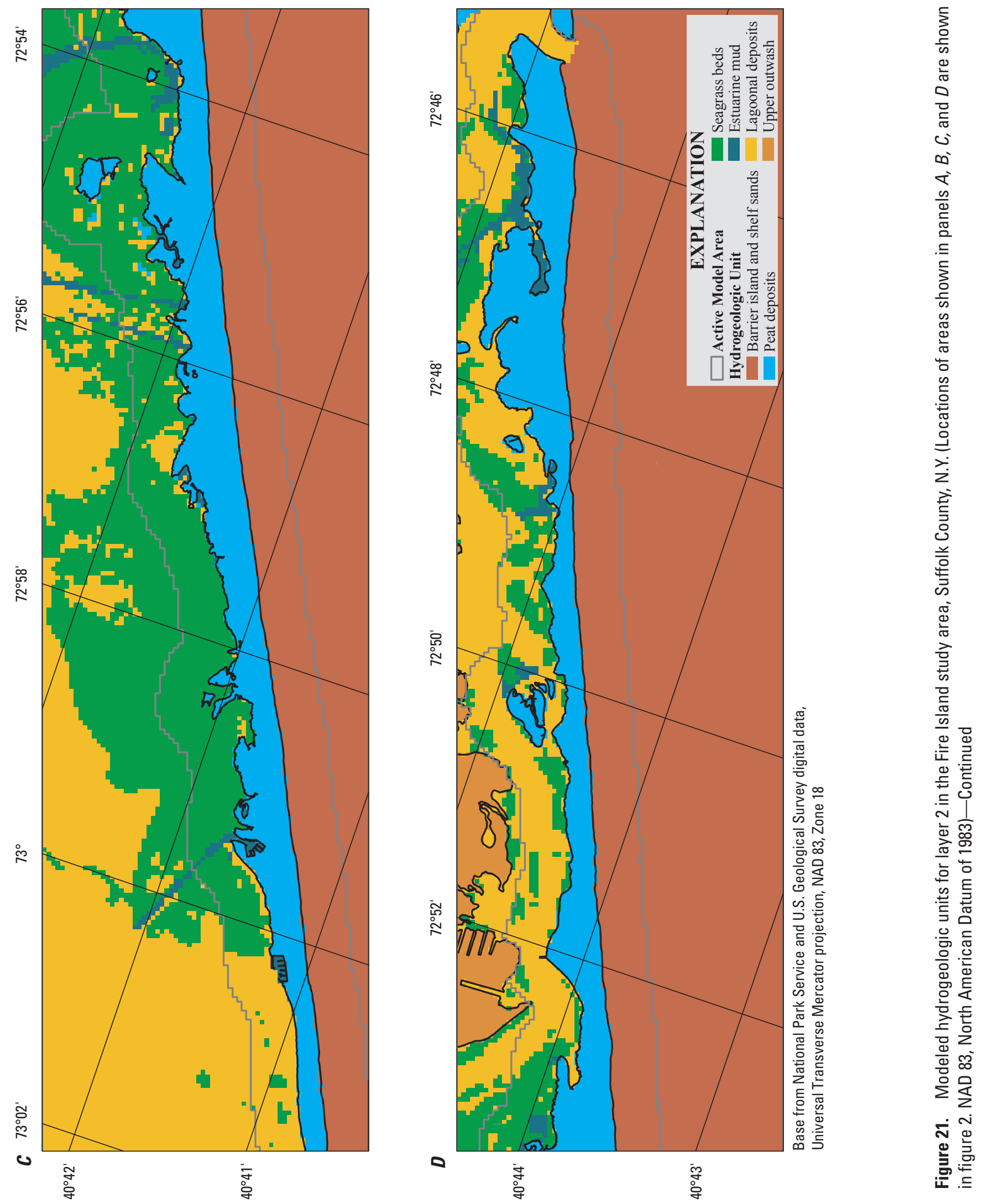

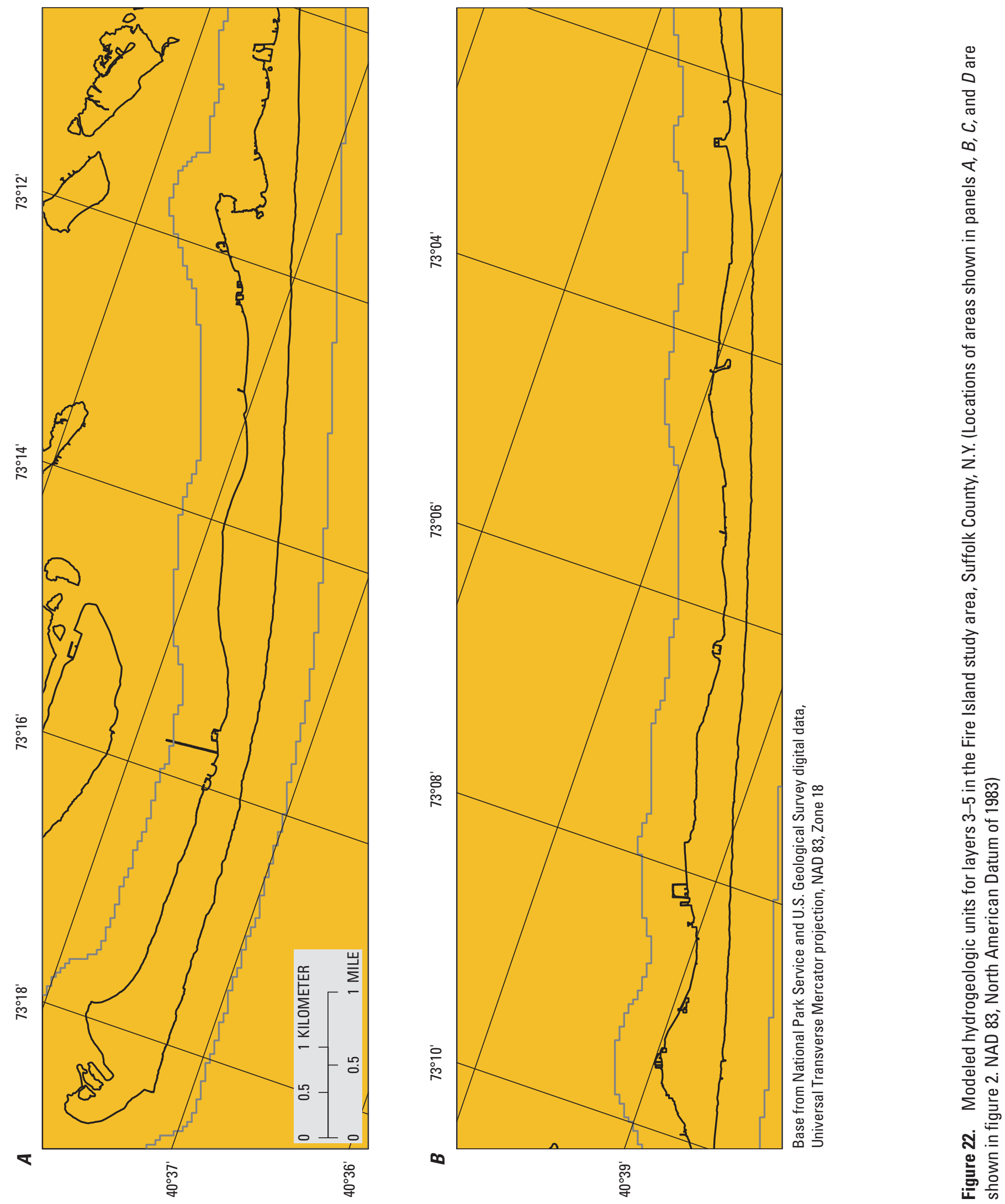

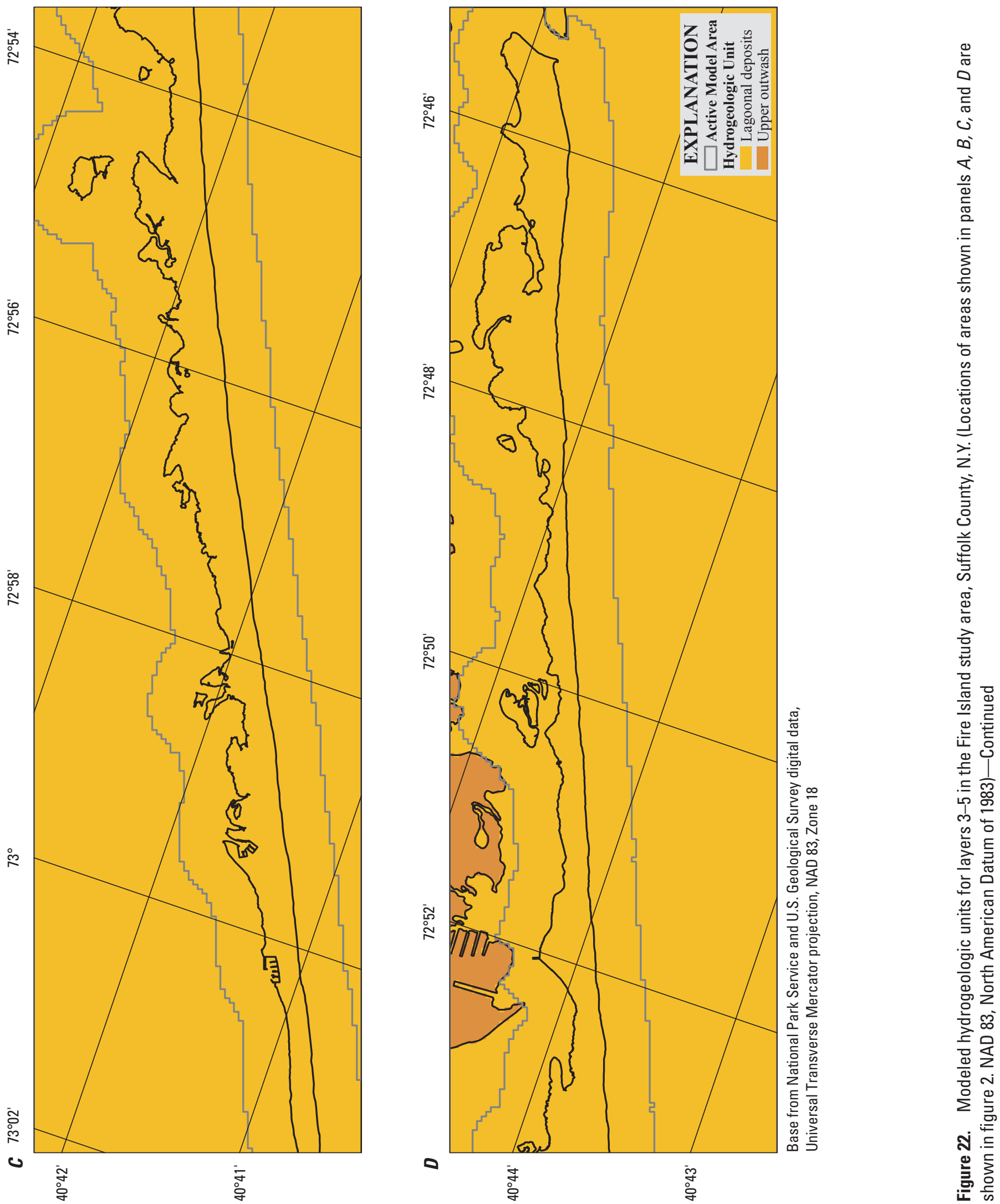

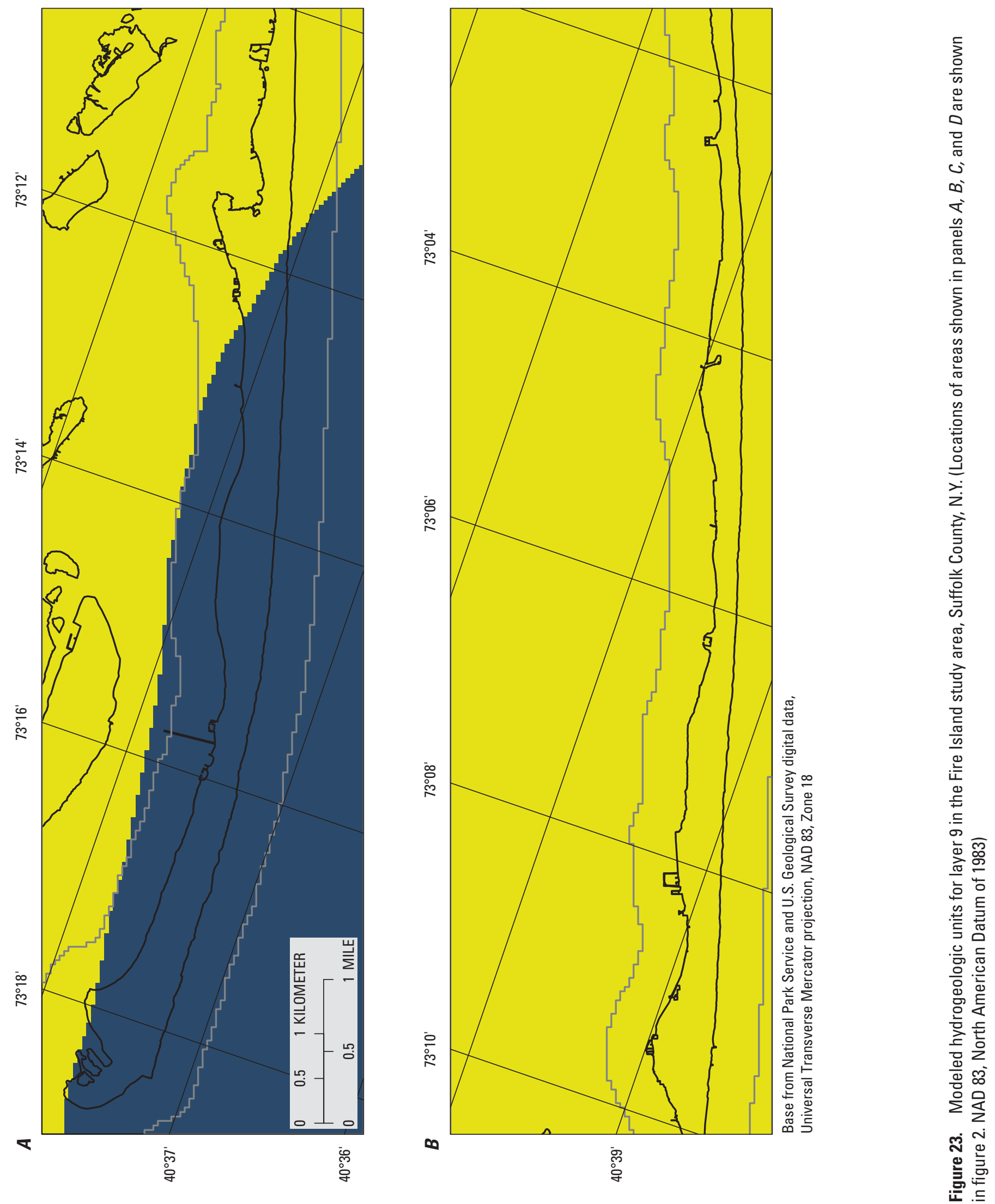

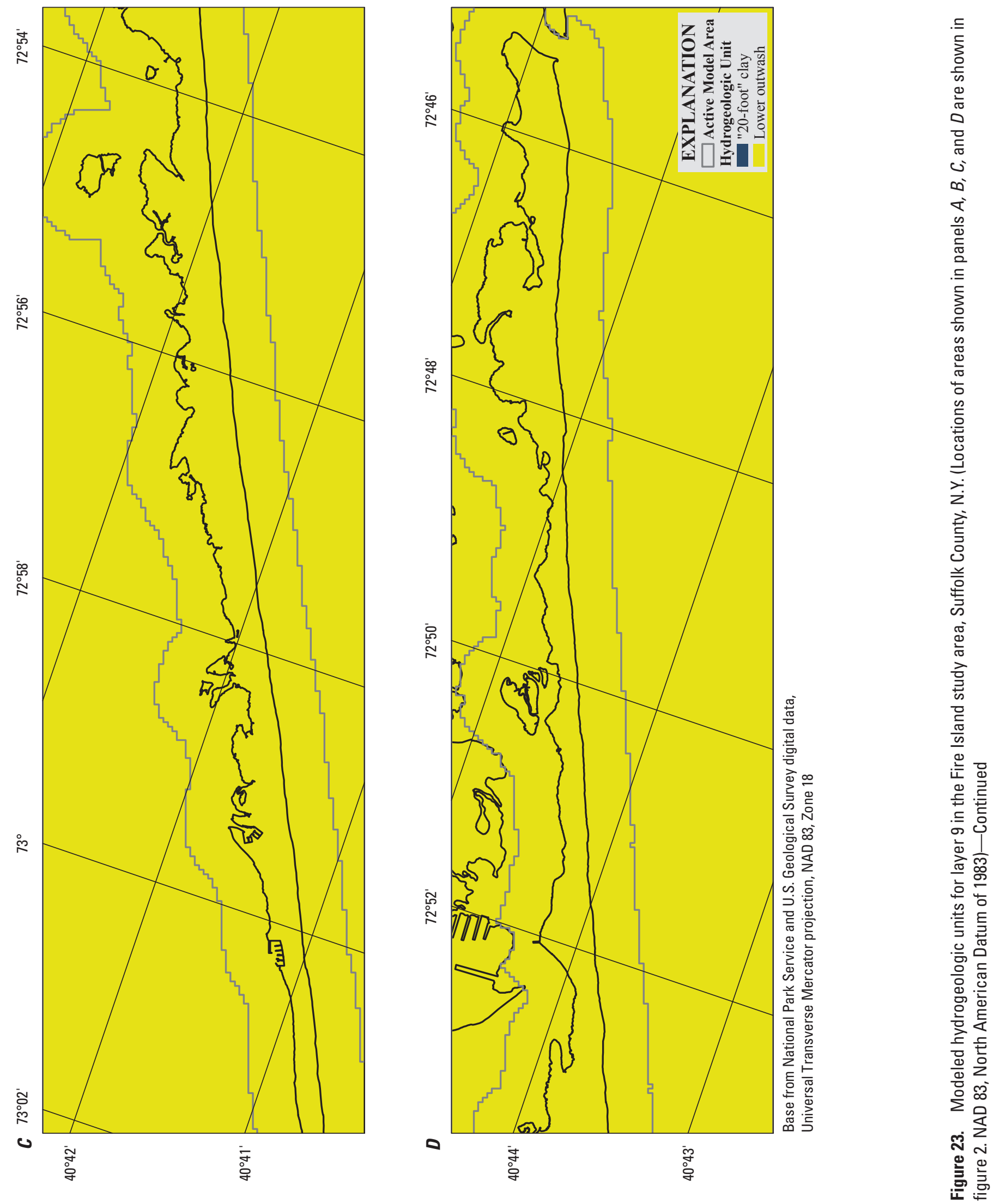

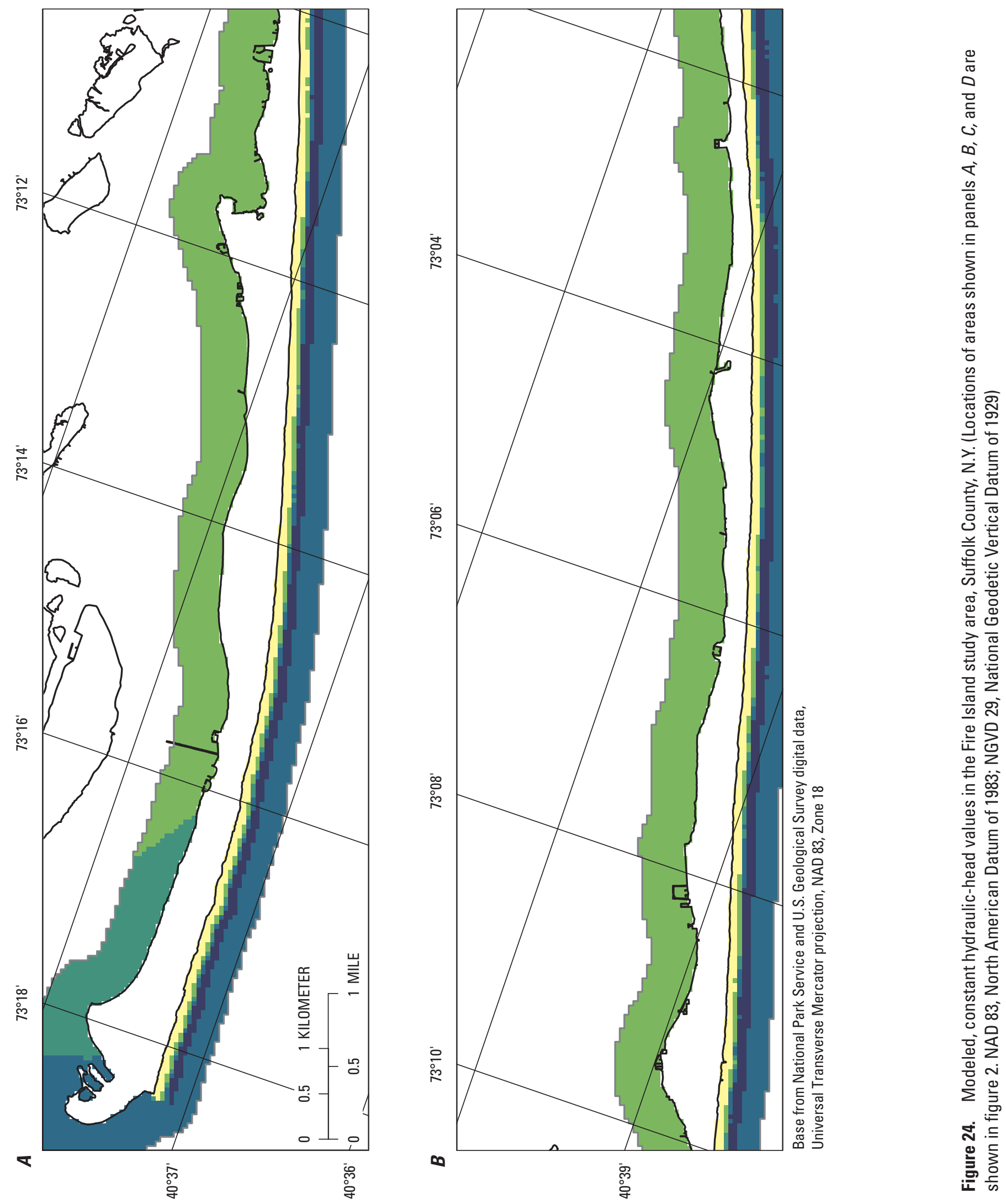

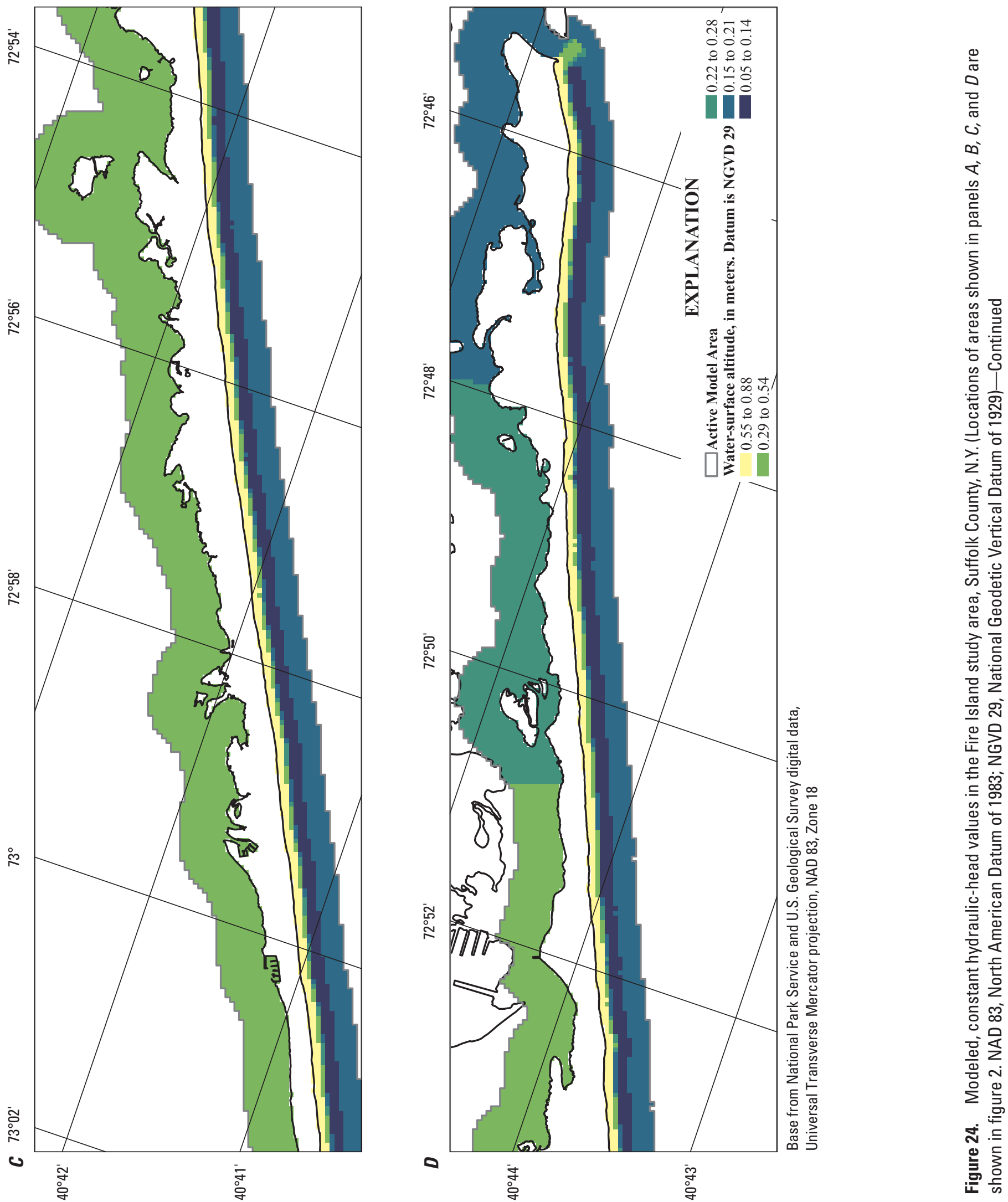

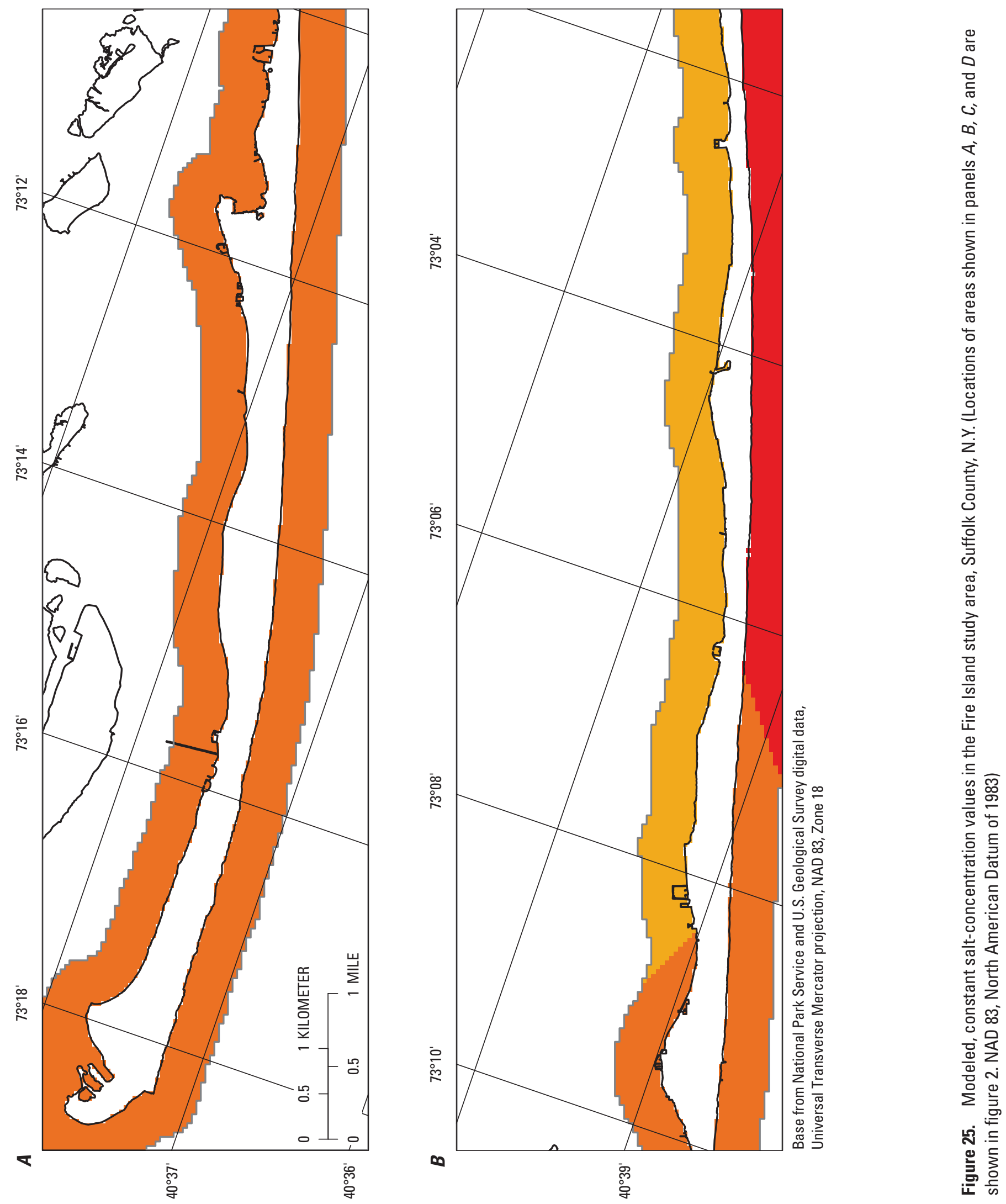

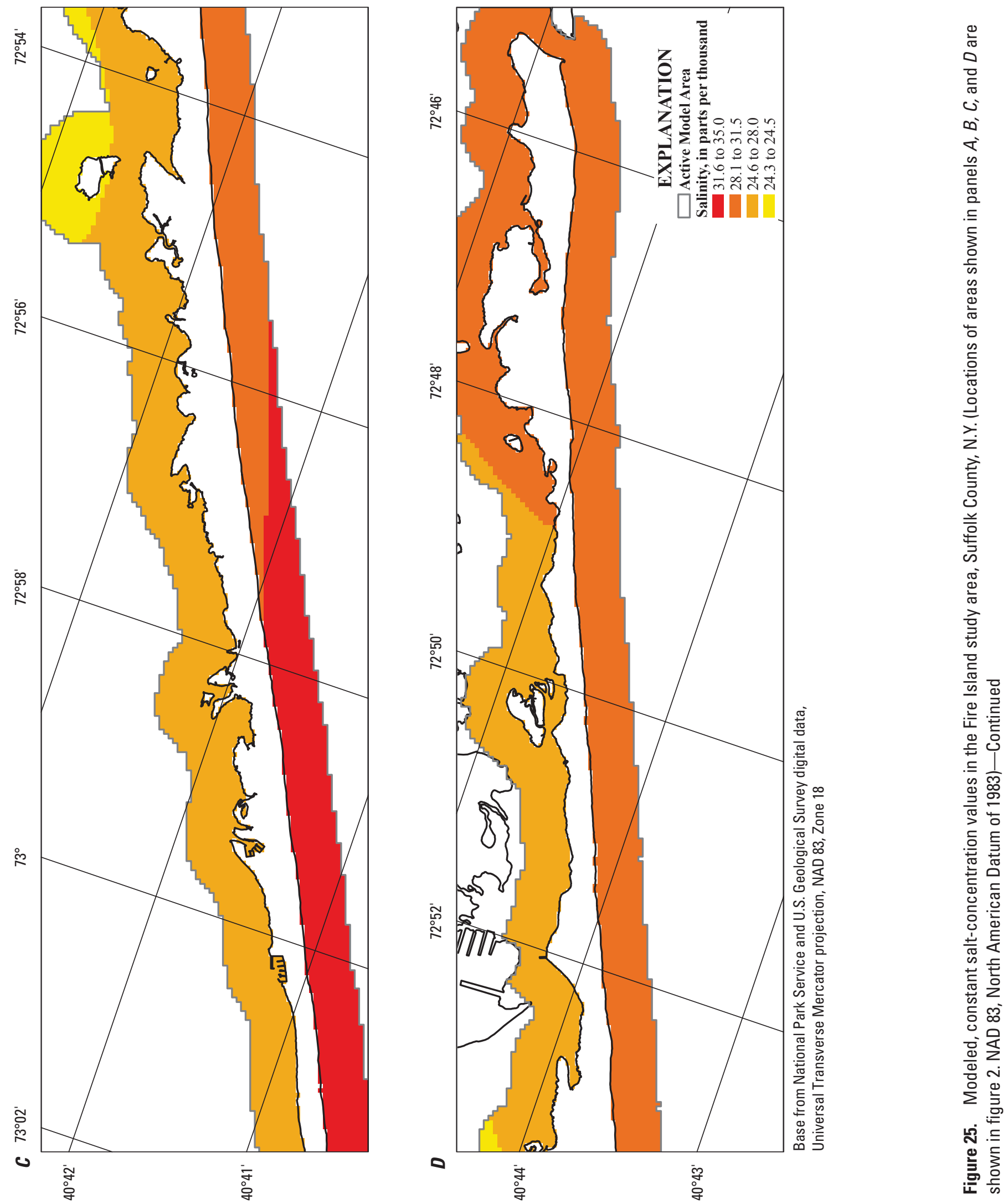

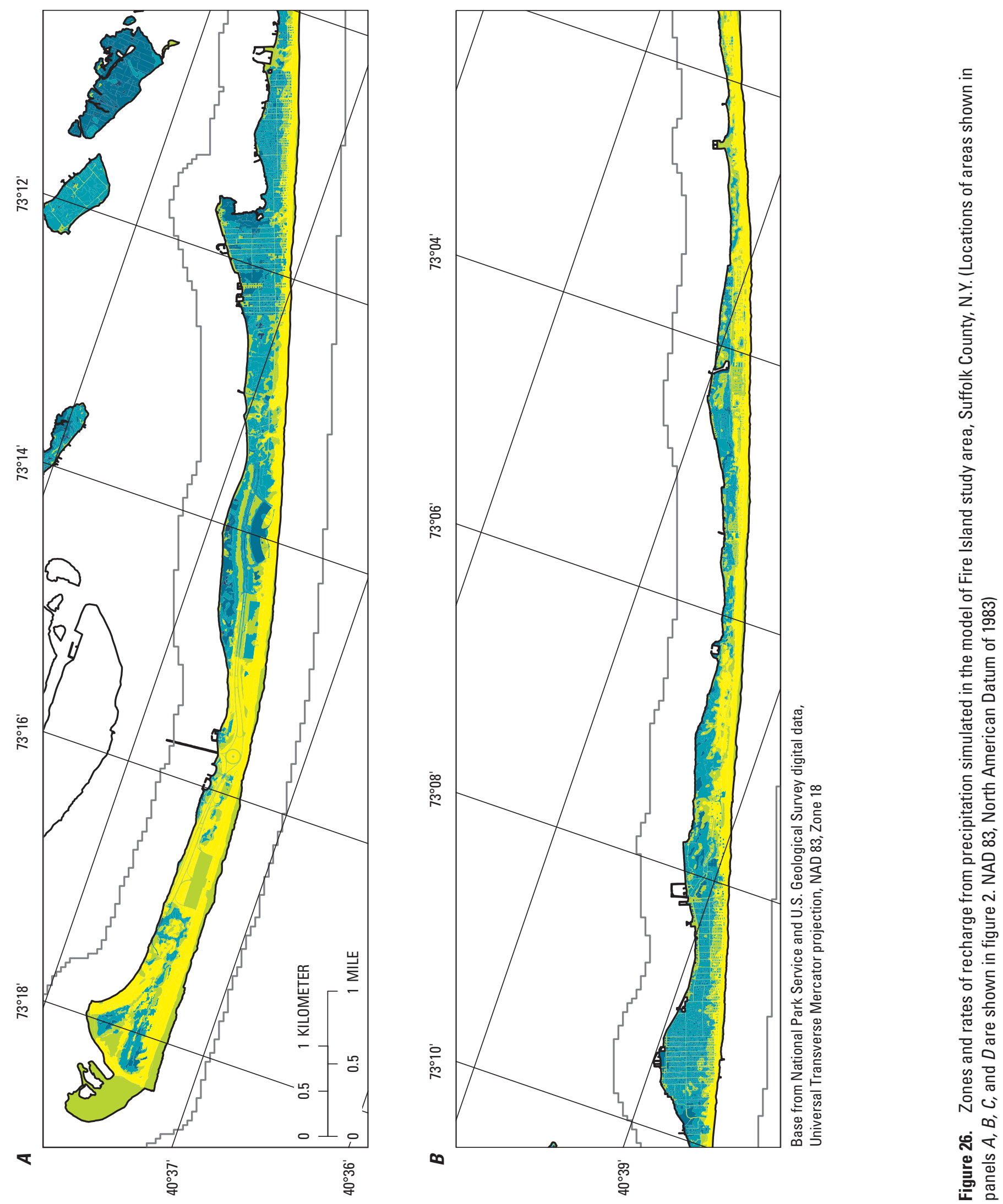

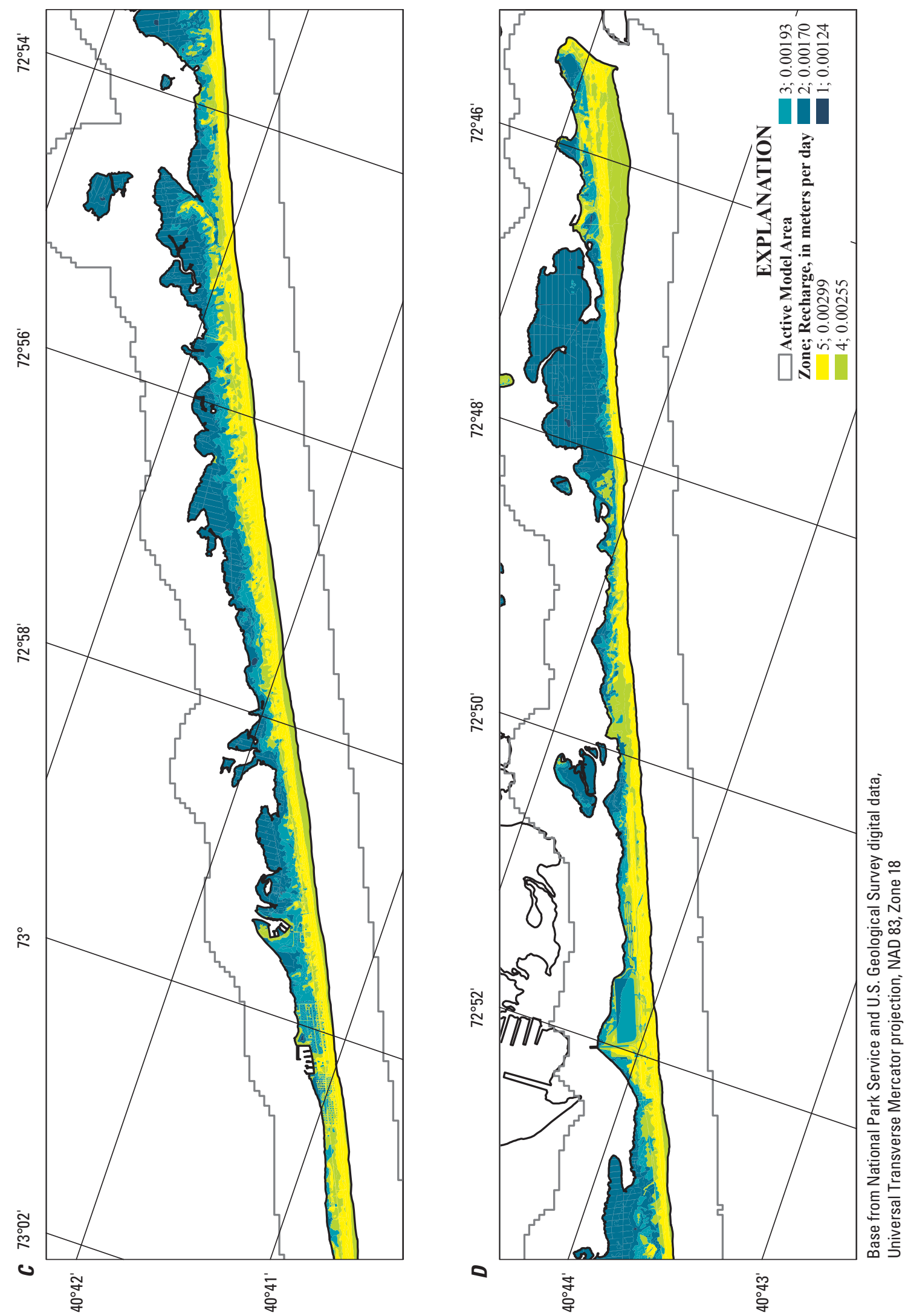

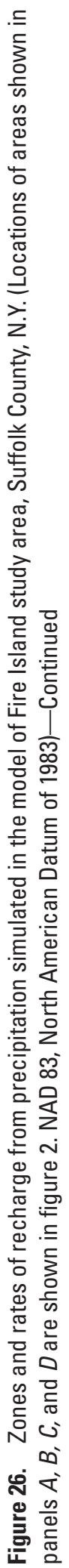


Table 8. Simulated zones of recharge from precipitation in the model of Fire Island study area, Suffolk County, N.Y.

[Land-surface altitude in meters above National Geodetic Vertical Datum of 1929. Locations of recharge zones are shown in figure 26. Land cover and substrate information modified from Klopfer and others, 2002]

Recharge zones for land cover or substrate

\begin{tabular}{lcccc}
\multicolumn{1}{c}{ Land-surface altitude } & $\begin{array}{c}\text { Fresh } \\
\text { surface water }\end{array}$ & $\begin{array}{c}\text { Peat substrate } \\
\text { or developed feature }\end{array}$ & $\begin{array}{c}\text { Loam substrate } \\
\text { Sand substrate } \\
\text { or sparse vegetation }\end{array}$ & $\begin{array}{c}\text { L } \\
\text { Less than 2 }\end{array}$ \\
Between 2 and 4 & 1 & 2 & 4 & 5 \\
Greater than 4 & Not present & 3 & 5 & 5 \\
\hline
\end{tabular}

\section{Simulation of Steady-State Conditions}

Steady-state groundwater flow directions, velocities, and discharge rates under current (2005) conditions in the shallow aquifer system were generated from the numerical model. Cell-by-cell flows output from SEAWAT were used to create velocity vectors for the groundwater flow system. The simulated groundwater discharges were multiplied by representative $\mathrm{TN}$ concentrations in recharged water to calculate nitrogen loads to back-barrier estuaries and the ocean.

\section{Groundwater Flow}

The simulated water-table altitude under 2005 mean annual conditions is shown in figure 28 and can be compared with figure 4 , which depicts the measured hydraulic heads in the four local study areas. The extent of the unconfined freshwater flow system - where salinity is less than 0.4 part per thousand - within the surficial hydrogeologic units as well as simulated salinities in the adjacent saline groundwater also are depicted in figure 28. The simulated 2005 mean annual potentiometric-surface altitude and extent of the confined freshwater flow system beneath the peat deposits onshore and surficial Holocene units offshore are shown in figure 29. The simulated hydraulic heads in the unconfined and underlying confined flow systems generally increase with proximity to the ocean shore, where the modeled effects of wave setup and tidal pumping result in a water-table overheight. These heads also increase with barrier-island width in inland areas because of the collectively greater amount of simulated recharge received in such areas. The simulated potentiometric-surface altitude and extent of the confined freshwater flow system beneath the " 20 -foot" clay or, where absent, the upper outwash under 2005 mean annual conditions is depicted in figure 30 . Simulated salinity values indicate freshwater is present beneath these deposits in several isolated lens, at locations where the modeled barrier island is sufficiently wide to yield elevated hydraulic heads.

Similar patterns also are evident in figures 31A through D, which show the simulated 2005 mean annual water levels, flow vectors, and extent of freshwater within the shallow aquifer system in the four local study areas along model columns 190, 255, 569, and 790, respectively. These can be compared to figures $8 \mathrm{~A}-\mathrm{D}$, which depict the measured hydraulic heads and freshwater-saltwater interface along vertical sections $\mathrm{B}-\mathrm{B}^{\prime}$ through $\mathrm{E}-\mathrm{E}^{\prime}$. The simulated water levels and resulting flow vectors shown along the four model columns indicate the groundwater divide is skewed strongly toward the ocean shore in response to the modeled water-table overheight; they also indicate this divide extends virtually to the base of the shallow aquifer system. Where the modeled barrier island is sufficiently wide to yield elevated hydraulic heads (figs. 31 A and C), the groundwater divide originates within the freshwater flow system, which probably restricts the exchange of subsurface flow between back-barrier estuaries and the ocean. Where the barrier island is relatively narrow and heads are comparatively lower (figs. 31B and D), however, the divide originates along the ocean shore, which presumably enhances downward movement of saline water that may subsequently migrate beneath the freshwater flow system to back-barrier estuaries. 


\section{Discharge-Boundary Analysis}

Simulated groundwater flows between the shallow aquifer system and marine surface waters (layer 1) under 2005 mean-annual conditions are shown in figure 32. Negative groundwater flow from active model cells located along the immediate estuary shore into constant-head cells representing back-barrier estuaries simulates the shoreline underflow to these water bodies from the freshwater flow system (figs. 31A-D). Positive groundwater flow from constanthead cells located away from the immediate estuary shore into underlying active model cells simulates the recirculation of estuary water into the shallow aquifer system; this flow subsequently returns to the estuary along the freshwatersaltwater transition zone (figs. 31A-D). Negative groundwater flow from active model cells located beneath the modeled wave-setdown zone (about $200 \mathrm{~m}$ offshore) into constanthead cells representing the ocean simulates the shoreline underflow to this water body from the freshwater flow system; the negative flow also includes re-circulated seawater that previously infiltrated the shallow aquifer system along the immediate ocean shore and beyond $200 \mathrm{~m}$ offshore as positive flow (figs. 31A-D). Discharge to estuaries and the ocean from the freshwater flow system is calculated as the difference between the total discharge to each of these water bodies and the simulated groundwater flows from their respective constant-head cells into active model cells. Where the barrier island is relatively narrow, the resulting ocean discharge is positive and is assumed to represent the flow of a brackish mixture of freshwater and seawater beneath the freshwater flow system to back-barrier estuaries. In these locations, freshwater discharge to back-barrier estuaries is calculated as the difference between the total discharge to marine surface waters and the simulated groundwater flows from both estuary and ocean constant-head cells into active model cells.

Freshwater that exits the shallow aquifer system as seepage through confining layers (subsea underflow) cannot be directly measured in the model of this system because it does not explicitly represent subsea-discharge boundaries. Nevertheless, the simulated amount of freshwater seepage into saline groundwaters can be approximated from the difference between the total modeled recharge to the water table and freshwater discharge to marine surface waters. Groundwater budgets were developed for recharge areas of similar land use that contribute freshwater to back-barrier estuaries, the ocean, and subsea-discharge zones (table 13) on the basis of results of the discharge-boundary analysis (fig. 32). These budgets generally suggest that relatively minor amounts of freshwater may exit the shallow aquifer system as subsea underflow, except where the barrier island is relatively narrow. In these areas, the collectively smaller amount of simulated recharge to the water table limits the depth of the freshwater flow system, which extracts some flow from adjacent recharge areas just to sustain freshwater discharge directly to marine waters.

Results of the discharge-boundary analysis are consistent with the conceptual and numerical model of barrier-island groundwater flow. However, there is a large amount of uncertainty in model predictions of subsurface flow of saline groundwater. There also is uncertainty in the assumption that subsurface flows between back-barrier estuaries and the ocean do not cross budget-area boundaries. Consequently, the resulting estimates of groundwater discharge to these water bodies probably should be considered qualitative approximations of freshwater flow.

\section{Contributing-Area Analysis}

Areas that contribute recharge to back-barrier estuaries and the ocean are the only sources of freshwater discharge from the shallow aquifer system and were estimated by flowbased particle tracking. These contributing areas were defined by the forward-tracking of individual particles placed at the center of each model cell receiving recharge. The particle tracking post-processing package MODPATH (Pollock, 1994) was used in the analysis. Simulated contributing areas to marine surface waters (layer 1) under 2005 mean annual conditions are shown in figure 33 . The divide between simulated areas that contribute recharge to back-barrier estuaries and the ocean is skewed strongly toward the ocean shore, where the modeled effects of wave setup and tidal pumping result in the water-table overheight. Simulated areas that do not contribute recharge to these water bodies are assumed to provide a source of freshwater that may exit as subsea underflow.

Groundwater budgets were developed for recharge areas of similar land use that contribute freshwater to back-barrier estuaries, the ocean, and subsea-discharge zones (table 14) on the basis of results of the contributing-area analysis (fig. 33). These budgets indicate that total freshwater discharge from the shallow aquifer system is about $43,500 \mathrm{~m}^{3} / \mathrm{d}$ (79.8 percent) to back-barrier estuaries and about $10,200 \mathrm{~m}^{3} / \mathrm{d}$ (18.7 percent) to the ocean; about $836 \mathrm{~m}^{3} / \mathrm{d}$ (1.5 percent) may exit the system as subsea underflow. The total contribution of fresh groundwater to shoreline discharge zones amounts to about $53,700 \mathrm{~m}^{3} / \mathrm{d}$ (98.5 percent) - nearly the same as that resulting from the discharge-boundary analysis, which is about $52,800 \mathrm{~m}^{3} / \mathrm{d}$ (96.9 percent). In contrast to the generally consistent budget estimate for estuary zones from the discharge-boundary analysis, which is about $46,200 \mathrm{~m}^{3} / \mathrm{d}$ ( 84.8 percent), the ocean and subsea-discharge zone estimates from this analysis are only somewhat comparable, amounting to about 6,570 (12.1 percent) and $2,760 \mathrm{~m}^{3} / \mathrm{d}$ (5.1 percent), respectively. 

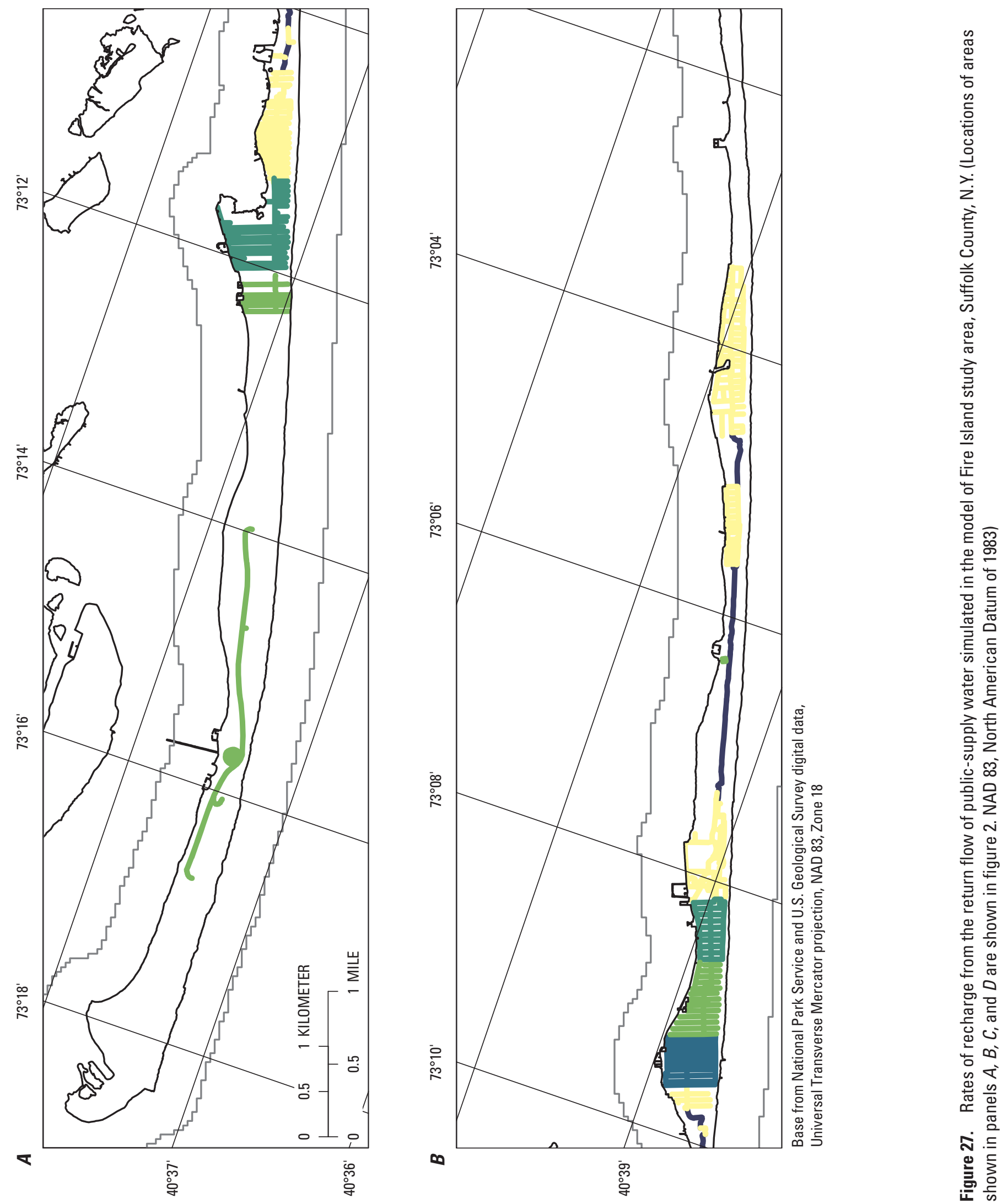

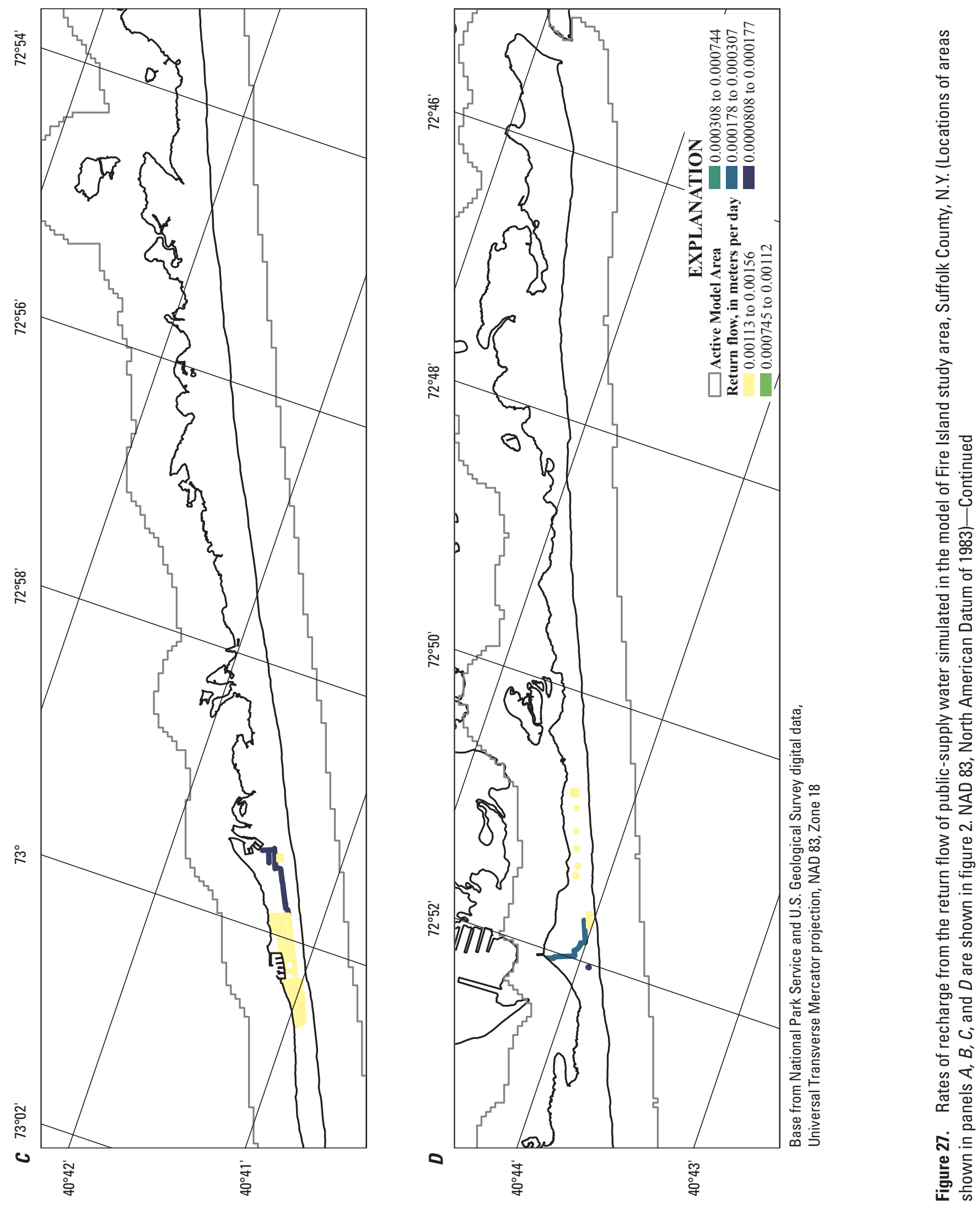
Table 9. Differences between measured and simulated water levels at wells in four areas of Fire Island, Suffolk County, N.Y.

[Water levels are in meters above National Geodetic Vertical Datum of 1929. Well locations are shown in figure 4. Well number is assigned by New York State Department of Environmental Conservation; prefix "S" denoting Suffolk County is omitted]

\begin{tabular}{|c|c|c|c|}
\hline \multirow{2}{*}{ Well number } & \multicolumn{3}{|c|}{ Groundwater level } \\
\hline & Measured & Simulated & 'Difference \\
\hline \multicolumn{4}{|c|}{ KISMET } \\
\hline 125370 & 0.52 & 0.57 & -0.05 \\
\hline 125371 & 0.98 & 1.05 & -0.06 \\
\hline 125385 & 0.92 & 0.88 & 0.04 \\
\hline 125981 & 1.05 & 1.00 & 0.05 \\
\hline 125983 & 0.92 & 1.01 & -0.09 \\
\hline 125984 & 0.90 & 0.88 & 0.02 \\
\hline 125986 & 1.00 & 1.02 & -0.01 \\
\hline 125995 & 0.98 & 1.03 & -0.05 \\
\hline 126753 & 1.00 & 1.01 & -0.01 \\
\hline Mean & & & -0.02 \\
\hline Standard deviation & & & 0.05 \\
\hline \multicolumn{4}{|c|}{ ROBBINS REST } \\
\hline 125982 & 0.75 & 0.80 & -0.05 \\
\hline 125994 & 0.77 & 0.86 & -0.10 \\
\hline 125996 & 0.65 & 0.53 & 0.12 \\
\hline 125997 & 0.71 & 0.67 & 0.05 \\
\hline 125998 & 0.75 & 0.74 & 0.01 \\
\hline 125999 & 0.80 & 0.82 & -0.03 \\
\hline 126000 & 0.75 & 0.79 & -0.04 \\
\hline 126001 & 0.69 & 0.74 & -0.06 \\
\hline Mean & & & -0.01 \\
\hline Standard deviation & & & 0.06 \\
\hline \multicolumn{4}{|c|}{ WATCH HILL } \\
\hline 125380 & 0.87 & 0.92 & -0.04 \\
\hline 125381 & 0.86 & 0.84 & 0.02 \\
\hline 125382 & 0.83 & 0.78 & 0.05 \\
\hline 125383 & 0.93 & 0.90 & 0.03 \\
\hline 125384 & 0.91 & 0.91 & 0.00 \\
\hline 125385 & 0.94 & 0.92 & 0.02 \\
\hline 125386 & 0.83 & 0.88 & -0.05 \\
\hline 125387 & 0.79 & 0.72 & 0.07 \\
\hline 125990 & 0.92 & 0.88 & 0.04 \\
\hline Mean & & & 0.01 \\
\hline Standard deviation & & & 0.04 \\
\hline \multicolumn{4}{|c|}{ NATIONAL WILDERNESS } \\
\hline 124399 & 0.88 & 0.83 & 0.05 \\
\hline 124400 & 0.96 & 0.89 & 0.07 \\
\hline 125363 & 0.73 & 0.78 & -0.05 \\
\hline 125364 & 0.71 & 0.71 & 0.00 \\
\hline 125365 & 0.61 & 0.48 & 0.12 \\
\hline 125366 & 0.66 & 0.63 & 0.03 \\
\hline 125367 & 0.81 & 0.81 & 0.01 \\
\hline 125368 & 0.69 & 0.77 & -0.07 \\
\hline 125369 & 0.77 & 0.70 & 0.07 \\
\hline Mean & & & 0.03 \\
\hline Standard deviation & & & 0.06 \\
\hline
\end{tabular}

${ }^{1}$ Amount may not equal the sum of values because of rounding to significant digits. 
Table 10. Differences between measured and simulated water levels at wells screened in four hydrogeologic units simulated in the model of Fire Island, Suffolk County, N.Y.

[Water levels are in meters above National Geodetic Vertical Datum of 1929. Well locations are shown in figure 4. Well number is assigned by New York State Department of Environmental Conservation; prefix "S" denoting Suffolk County is omitted]

\begin{tabular}{|c|c|c|c|}
\hline \multirow{2}{*}{ Well number } & \multicolumn{3}{|c|}{ Groundwater level } \\
\hline & Measured & Simulated & 'Difference \\
\hline \multicolumn{4}{|c|}{ BARRIER ISLAND AND SHELF SANDS } \\
\hline 124400 & 0.96 & 0.89 & 0.07 \\
\hline 125365 & 0.61 & 0.48 & 0.12 \\
\hline 125371 & 0.98 & 1.05 & -0.06 \\
\hline 125387 & 0.79 & 0.72 & 0.07 \\
\hline Mean & & & 0.05 \\
\hline Standard deviation & & & 0.07 \\
\hline \multicolumn{4}{|c|}{ PEAT DEPOSITS } \\
\hline 125370 & 0.52 & 0.57 & -0.05 \\
\hline 125994 & 0.77 & 0.86 & -0.10 \\
\hline 125995 & 0.98 & 1.03 & -0.05 \\
\hline Mean & & & -0.07 \\
\hline Standard deviation & & & 0.02 \\
\hline \multicolumn{4}{|c|}{ LAG00NAL DEPOSITS } \\
\hline 125363 & 0.73 & 0.78 & -0.05 \\
\hline 125364 & 0.71 & 0.71 & 0.00 \\
\hline 125366 & 0.66 & 0.63 & 0.03 \\
\hline 125367 & 0.81 & 0.81 & 0.01 \\
\hline 125368 & 0.69 & 0.77 & -0.07 \\
\hline 125380 & 0.87 & 0.92 & -0.04 \\
\hline 125381 & 0.86 & 0.84 & 0.02 \\
\hline 125382 & 0.83 & 0.78 & 0.05 \\
\hline 125383 & 0.93 & 0.90 & 0.03 \\
\hline 125384 & 0.91 & 0.91 & 0.00 \\
\hline 125385 & 0.94 & 0.92 & 0.02 \\
\hline 125386 & 0.83 & 0.88 & -0.05 \\
\hline 125981 & 1.05 & 1.00 & 0.05 \\
\hline 125982 & 0.75 & 0.80 & -0.05 \\
\hline 125983 & 0.92 & 1.01 & -0.09 \\
\hline 125984 & 0.90 & 0.88 & 0.02 \\
\hline 125985 & 0.92 & 0.88 & 0.04 \\
\hline 125986 & 1.00 & 1.02 & -0.01 \\
\hline 125996 & 0.65 & 0.53 & 0.12 \\
\hline 125997 & 0.71 & 0.67 & 0.05 \\
\hline 125998 & 0.75 & 0.74 & 0.01 \\
\hline 125999 & 0.80 & 0.82 & -0.03 \\
\hline 126000 & 0.75 & 0.79 & -0.04 \\
\hline 126001 & 0.69 & 0.74 & -0.06 \\
\hline 126753 & 1.00 & 1.01 & -0.01 \\
\hline Mean & & & -0.00 \\
\hline Standard deviation & & & 0.05 \\
\hline \multicolumn{4}{|c|}{ UPPER OUTWASH } \\
\hline 124399 & 0.88 & 0.83 & 0.05 \\
\hline 125369 & 0.77 & 0.70 & 0.07 \\
\hline 125990 & 0.92 & 0.88 & 0.04 \\
\hline Mean & & & 0.05 \\
\hline Standard deviation & & & 0.01 \\
\hline
\end{tabular}

${ }^{1}$ Amount may not equal the sum of values because of rounding to significant digits. 


\section{Analysis of the Shallow Groundwater Flow System at Fire Island National Seashore, Suffolk County, New York}

Table 11. Measured and simulated water levels and vertical hydraulic gradients at five observation-well pairs on Fire Island, Suffolk County, N.Y.

[Water levels are in meters above National Geodetic Vertical Datum of 1929. Well locations are shown in figure 4. Well number is assigned by New York State Department of Environmental Conservation; prefix "S" denoting Suffolk County is omitted. --, no value]

\begin{tabular}{|c|c|c|c|c|c|}
\hline \multirow{3}{*}{$\begin{array}{ll} & \text { Statistic } \\
\text { Local study area } & \\
\text { UPPER WELL } & \end{array}$} & \multicolumn{5}{|c|}{ Well number } \\
\hline & \multirow{2}{*}{$\begin{array}{c}\text { Kismet } \\
125986\end{array}$} & \multirow{2}{*}{$\begin{array}{c}\text { Robbins Rest } \\
125982\end{array}$} & \multirow{2}{*}{$\begin{array}{c}\text { Watch Hill } \\
125383 \\
\end{array}$} & \multicolumn{2}{|c|}{ National Wilderness } \\
\hline & & & & 125364 & 124400 \\
\hline Simulated groundwater level & 1.02 & 0.80 & 0.90 & 0.71 & 0.89 \\
\hline LOWER WELL & 126753 & 126000 & 125990 & 125369 & 124399 \\
\hline Simulated groundwater level & 1.01 & 0.79 & 0.88 & 0.70 & 0.83 \\
\hline \multicolumn{6}{|c|}{ 'RELATION BETWEEN GROUNDWATER LEVELS IN UPPER AND LOWER WELLS } \\
\hline Difference between measured values & 0.00 & 0.00 & 0.01 & -0.06 & 0.08 \\
\hline Difference between simulated values & 0.01 & 0.01 & 0.02 & 0.01 & 0.05 \\
\hline Measured gradient between upper and lower wells & 0.00000 & 0.00000 & 0.00045 & -0.01234 & 0.00383 \\
\hline
\end{tabular}

${ }^{1}$ Amount may not equal the sum of values because of rounding to significant digits.

Table 12. Final horizontal and vertical hydraulic conductivities for hydrogeologic units simulated in the model of Fire Island study area, Suffolk County, N.Y.

[Values are in meters per day]

\begin{tabular}{|c|c|c|c|c|}
\hline & & \multicolumn{3}{|c|}{ Hydraulic conductivity } \\
\hline \multicolumn{2}{|c|}{ Hydrogeologic unit } & Horizontal & Vertical & $\begin{array}{c}\text { Ratio of horizontal } \\
\text { to vertical }\end{array}$ \\
\hline \multirow[t]{4}{*}{ Surficial Holocene units } & Barrier island and shelf sands & 45 & 4.5 & $10: 1$ \\
\hline & Peat deposits & 2 & 0.02 & $100: 1$ \\
\hline & Seagrass beds & 4 & 0.04 & $100: 1$ \\
\hline & Estuarine mud & 0.3 & 0.003 & $100: 1$ \\
\hline \multirow[t]{2}{*}{ Lagoonal deposits } & Western zone & 25 & 1 & $25: 1$ \\
\hline & Eastern zone & 20 & 0.67 & $30: 1$ \\
\hline Upper outwash & & 30 & 1.5 & $20: 1$ \\
\hline "20-foot" clay & & 0.03 & 0.0003 & 100:1 \\
\hline \multirow[t]{3}{*}{ Lower outwash } & Upper zone & 20 & 0.67 & $30: 1$ \\
\hline & Middle zone & 10 & 0.1 & $100: 1$ \\
\hline & Lower zone & 3 & 0.03 & 100:1 \\
\hline
\end{tabular}


The contributing-area analysis also provided estimates of the traveltimes for individual particles from their point of recharge at the water table to their point of discharge at the shore. Results of particle-traveltime tracking indicate the median age of freshwater discharged to back-barrier estuaries and the ocean was 3.4 years, and the $95^{\text {th }}$-percentile age was 20 years. Particles that do not discharge to these water bodies - assumed to represent a source of freshwater that may exit as subsea underflow-were excluded from particletraveltime tracking.

\section{Nutrient Loads}

Nitrogen loading to estuaries and the ocean can originate from various sources, including freshwater discharge from the shallow aquifer system as well as saline and transitional water discharge. Because the potential sources of nutrients in the freshwater system are probably greatest, nitrogen loads were calculated for freshwater discharge. Nitrogen loads from the shallow aquifer system to back-barrier estuaries and the ocean were calculated as the simulated discharges from the contributing-area analysis multiplied by the representative TN concentrations for the principal land uses on Fire Island.

The nitrogen concentrations in undeveloped and developed park areas on Fire Island are assumed to be 0.29 and $1.63 \mathrm{mg} / \mathrm{L}$ as $\mathrm{N}$, respectively. These are median $\mathrm{TN}$ concentrations found in groundwater from 16 shallow wells - 7 in undeveloped and 9 in developed park areassampled in October 2005.

Nitrogen concentrations for the residential communities within FIIS are presumed to be comparable to median TN values calculated by Monti and Scorca (2003) for 747 samples collected at 63 shallow wells within a 1.6-km-wide zone along the southern, mainland coastline of Suffolk County. This mainland zone includes areas of predominantly residential development similar to the Fire Island communities.

For communities consisting mainly of low- to mediumdensity residential development, the nitrogen concentration is estimated in this study to be generally equivalent to a median TN concentration of $1.19 \mathrm{mg} / \mathrm{L}$ calculated for the unsewered area east of Carmans River (fig. 2) during the period 1982-97 (Monti and Scorca, 2003). The concentration of TN in communities consisting primarily of high-density residential development is estimated to be generally equivalent to a median value of $2.69 \mathrm{mg} / \mathrm{L}$ calculated for the unsewered area west of Carmans River during 1982-97 (Monti and Scorca, 2003). For the sewered community of Ocean Beach, the concentration is estimated to be generally equivalent to a median TN value of $0.86 \mathrm{mg} / \mathrm{L}$ that Monti and Scorca (2003) calculated for the Southwest Sewer District (fig. 1) during this same period.
Residency in the mainland areas is mostly year-round, so these areas could generate a larger wastewater load annually than those areas occupied mainly during summer. However, the intense summer visitation of Fire Island could result in a higher seasonal wastewater load than would be produced by a permanent population in the same density of residential development. TN concentrations from four wells downgradient from two communities-Kismet and Robbins Rest—sampled during this study (S126753, S125370, S125994, and S126000; figs. 16A and B) show reasonable agreement with the median TN concentrations calculated by Monti and Scorca (2003); therefore, the values from the southern Suffolk County mainland probably can be considered reasonable approximations of the median TN concentrations within the Fire Island communities.

The TN concentrations and loads under 2005 mean annual conditions for areas that contribute fresh groundwater to back-barrier estuaries and the ocean were summarized for the principal land uses on Fire Island (table 15). The overall TN load from the shallow aquifer system to shoreline discharge zones is about $16,200 \mathrm{~kg} / \mathrm{yr}(82.2$ percent) to back-barrier estuaries and about 3,500 kg/yr (17.8 percent) to the ocean (table 15). TN loads to estuary zones are about 2,590 (16.0 percent) and 4,730 kg/yr (29.2 percent) from undeveloped and developed park areas, respectively; about 63 ( 0.4 percent), 1,190 (7.3 percent), and 7,400 kg/yr (45.7 percent) from unsewered residential areas of low, medium, and high density, respectively; and about $203 \mathrm{~kg} / \mathrm{yr}$ ( 1.3 percent) from the sewered residential area.

The nitrogen-loading calculations in table 15 indicate the overall TN load from Fire Island to marine surface waters amounts to about $19,700 \mathrm{~kg} / \mathrm{yr}$ - roughly 6 percent of the annual TN load from shallow groundwater entering the South Shore Estuary Reserve (SSER) from the Suffolk County mainland, which is about $345,000 \mathrm{~kg} / \mathrm{yr}$ (Monti and Scorca, 2003). In contrast to the TN load from shallow groundwater for the entire 1,420- $\mathrm{km}^{2}$ SSER study area of Monti and Scorca (2003), which annually yields about $353 \mathrm{~kg}$ of nitrogen per square kilometer of watershed (table 16), the overall TN load from Fire Island produces nitrogen at an annual rate of about $890 \mathrm{~kg} / \mathrm{km}^{2}$ - more than double the loading rate from shallow groundwater to the SSER from the southern mainland of Nassau and Suffolk Counties. Similarly, the loading rate for Fire Island is nearly twice the annual rate of nitrogen loading from shallow groundwater entering Long Island Sound from the North Shore of Long Island, which is about $458 \mathrm{~kg} / \mathrm{km}^{2}$, as indicated by an earlier study (Scorca and Monti, 2001) that used load-calculation methods comparable to those of Monti and Scorca (2003) and this study. 

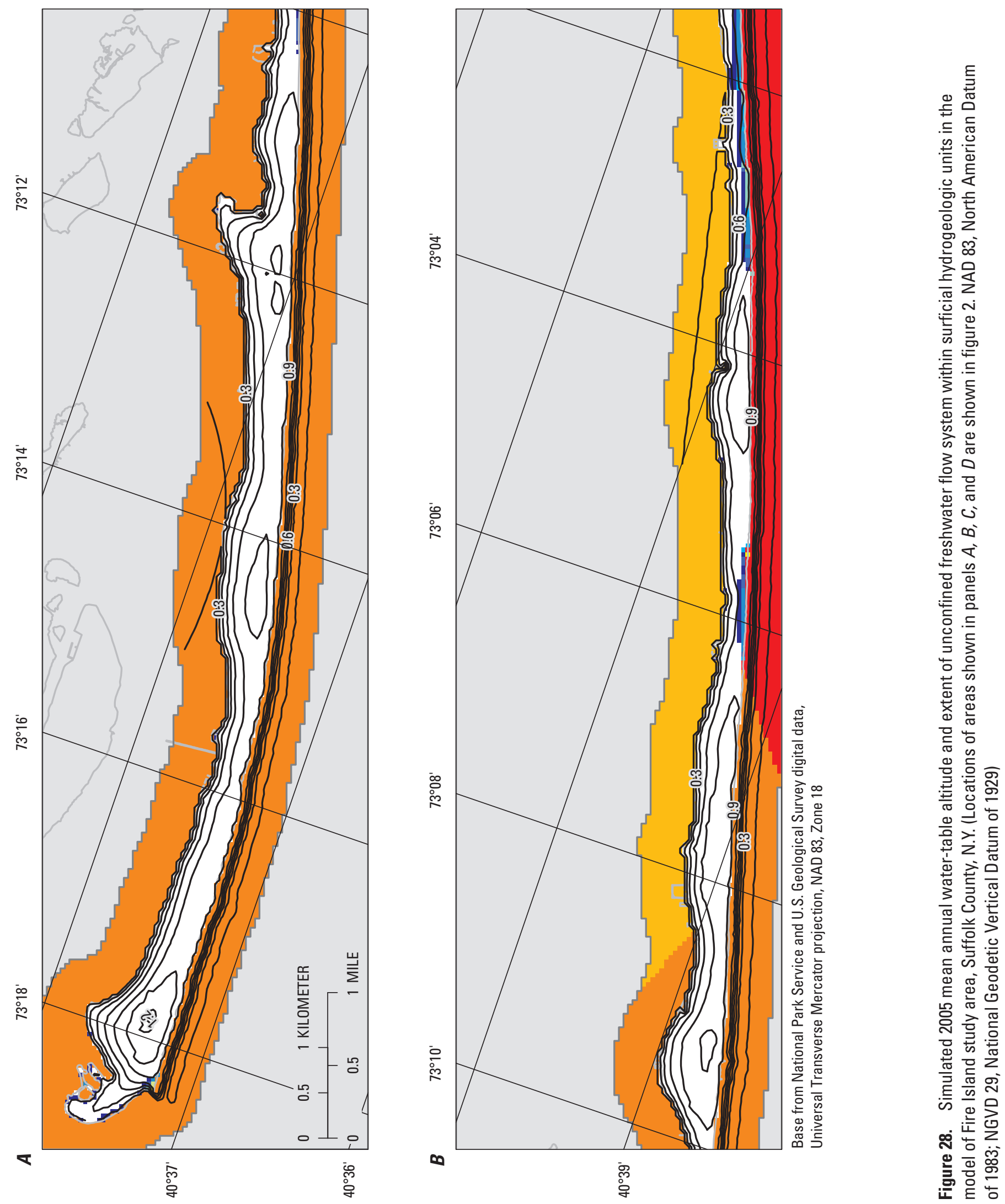

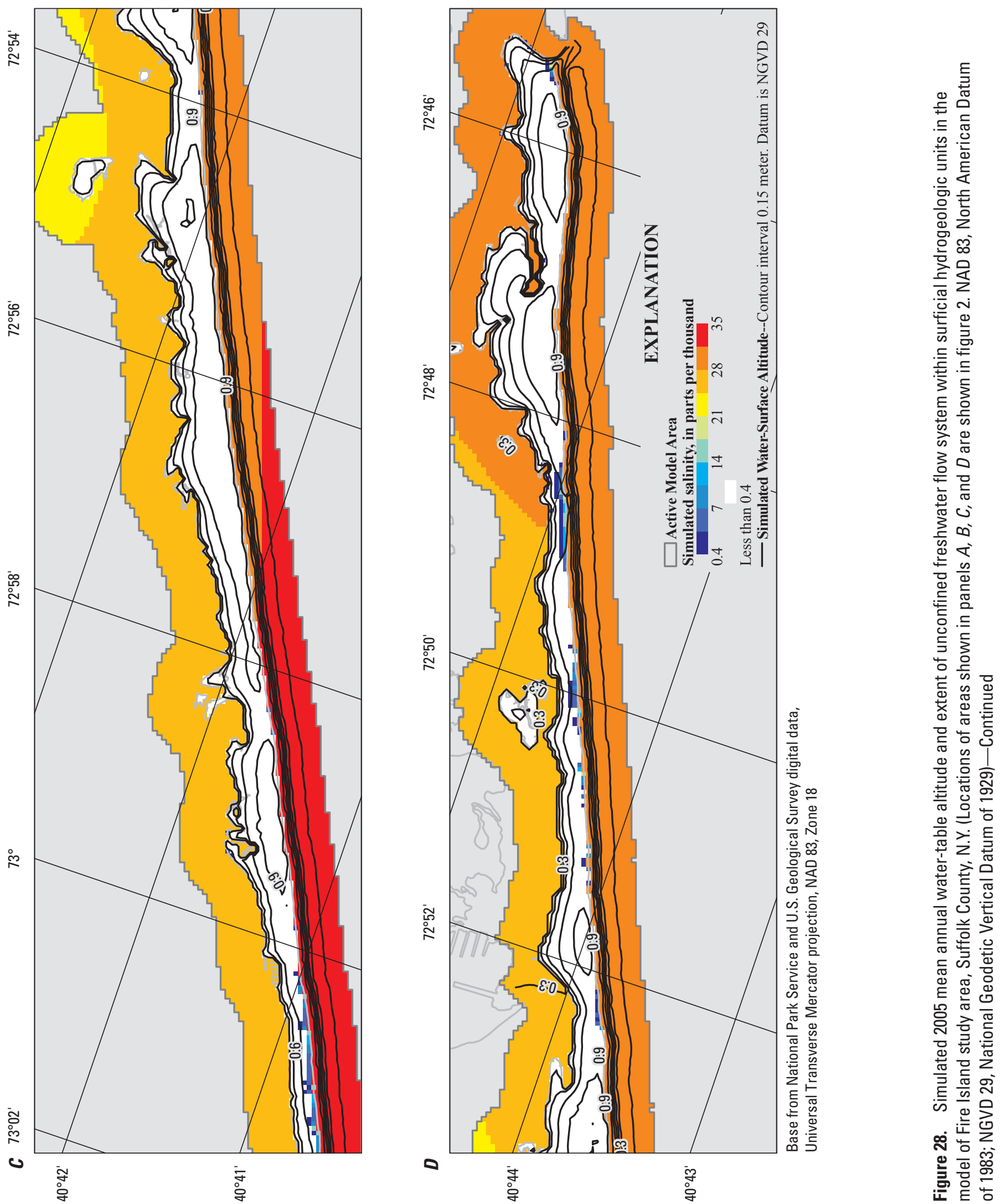

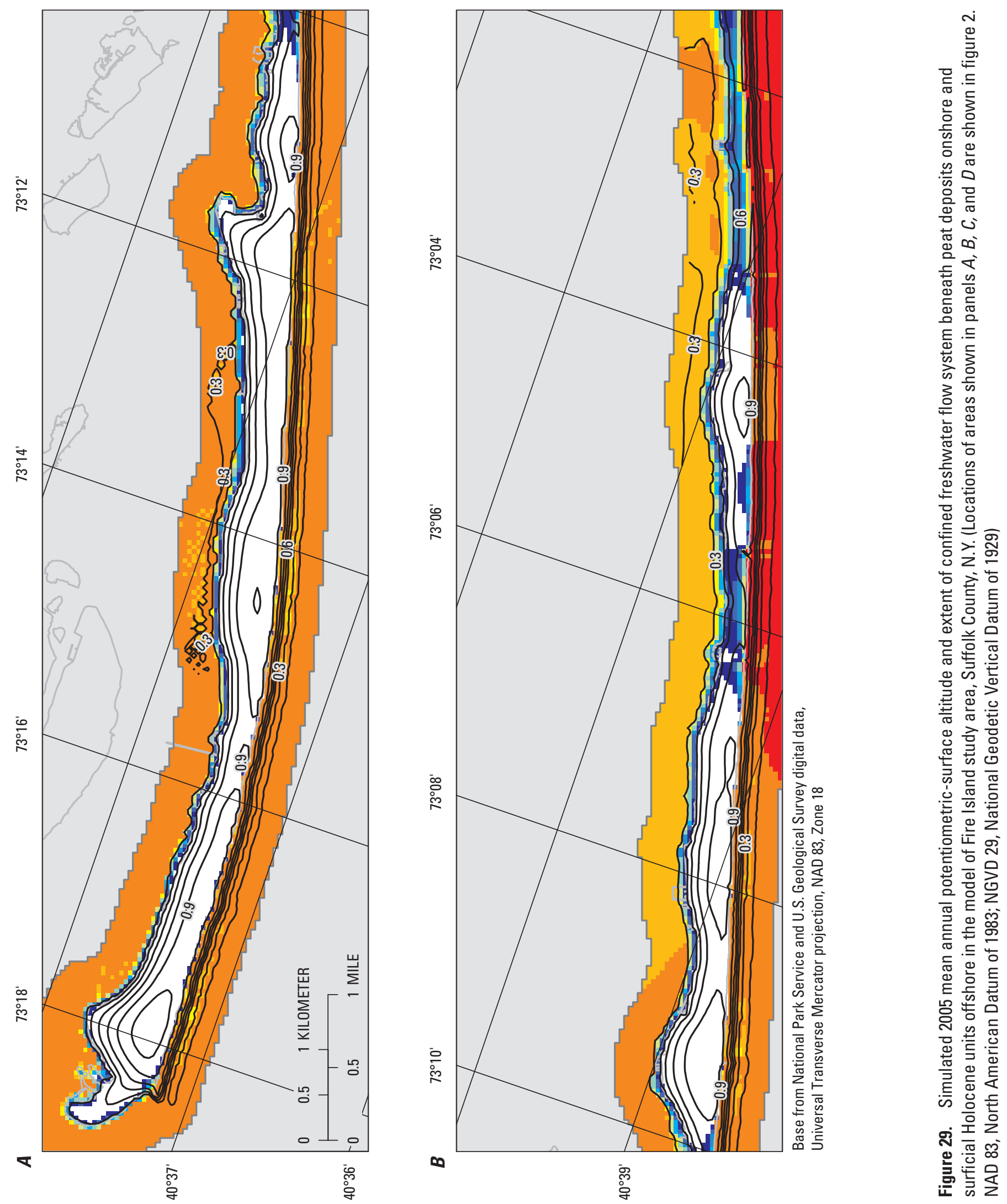

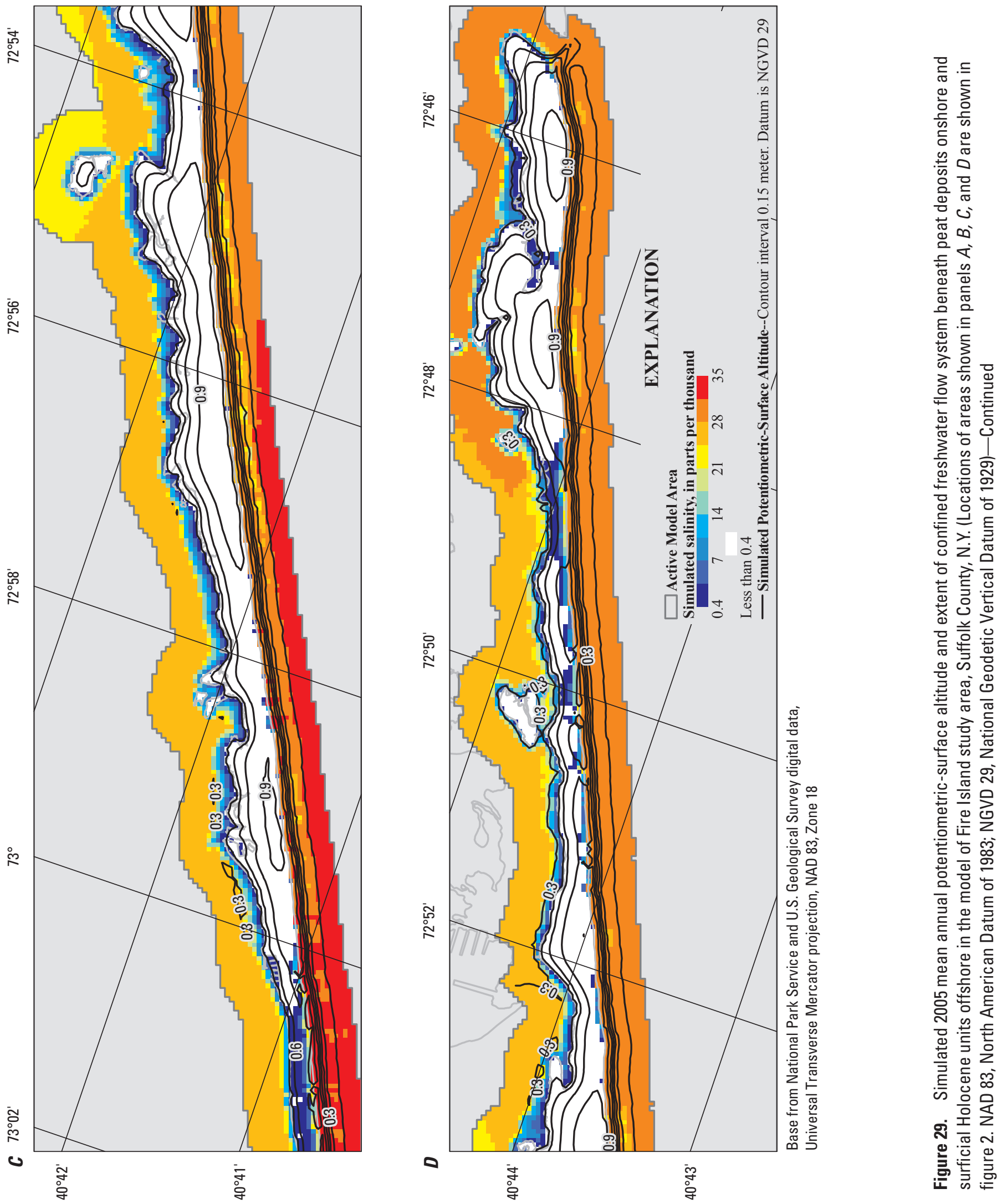

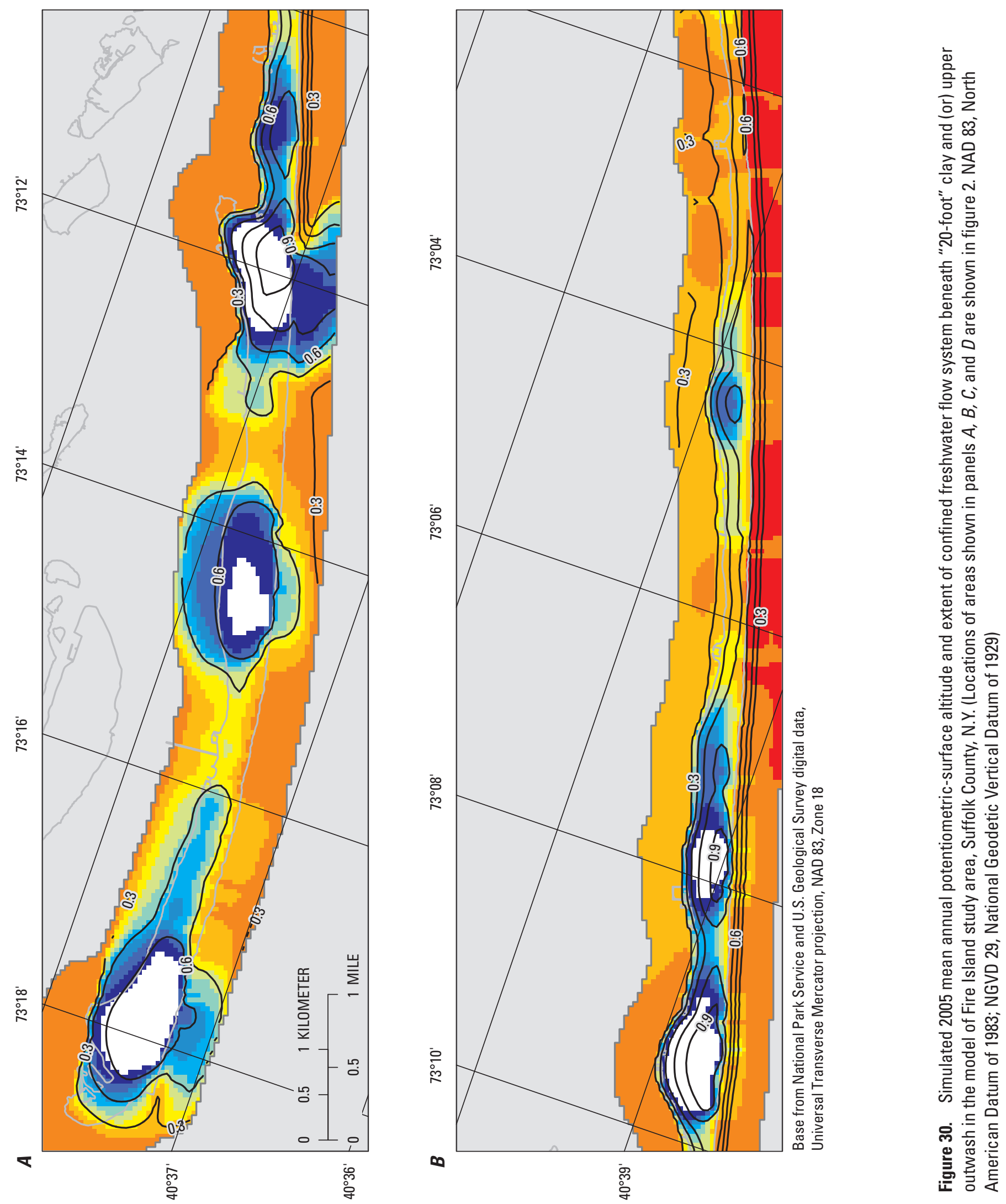

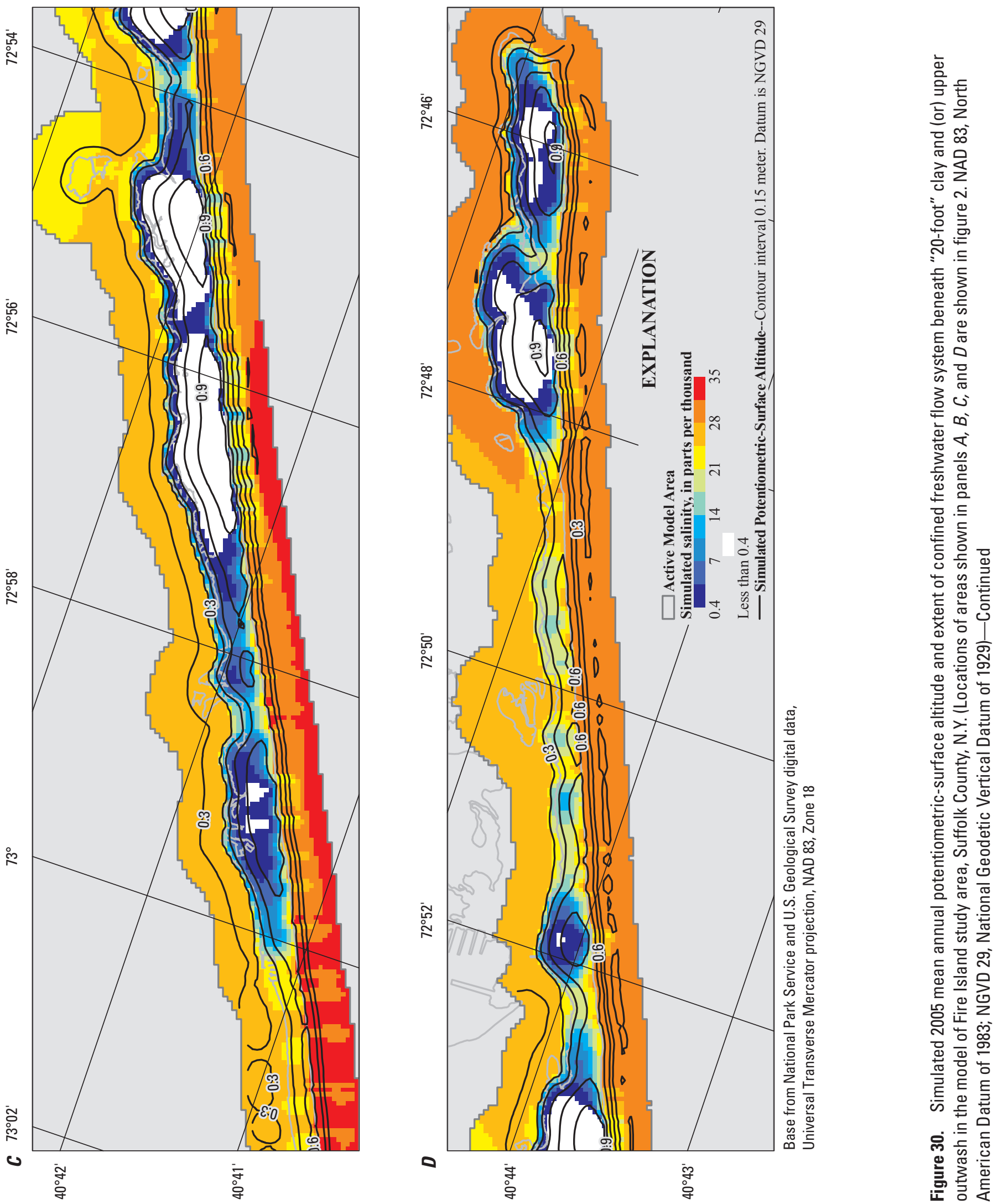


\section{A Column 190}

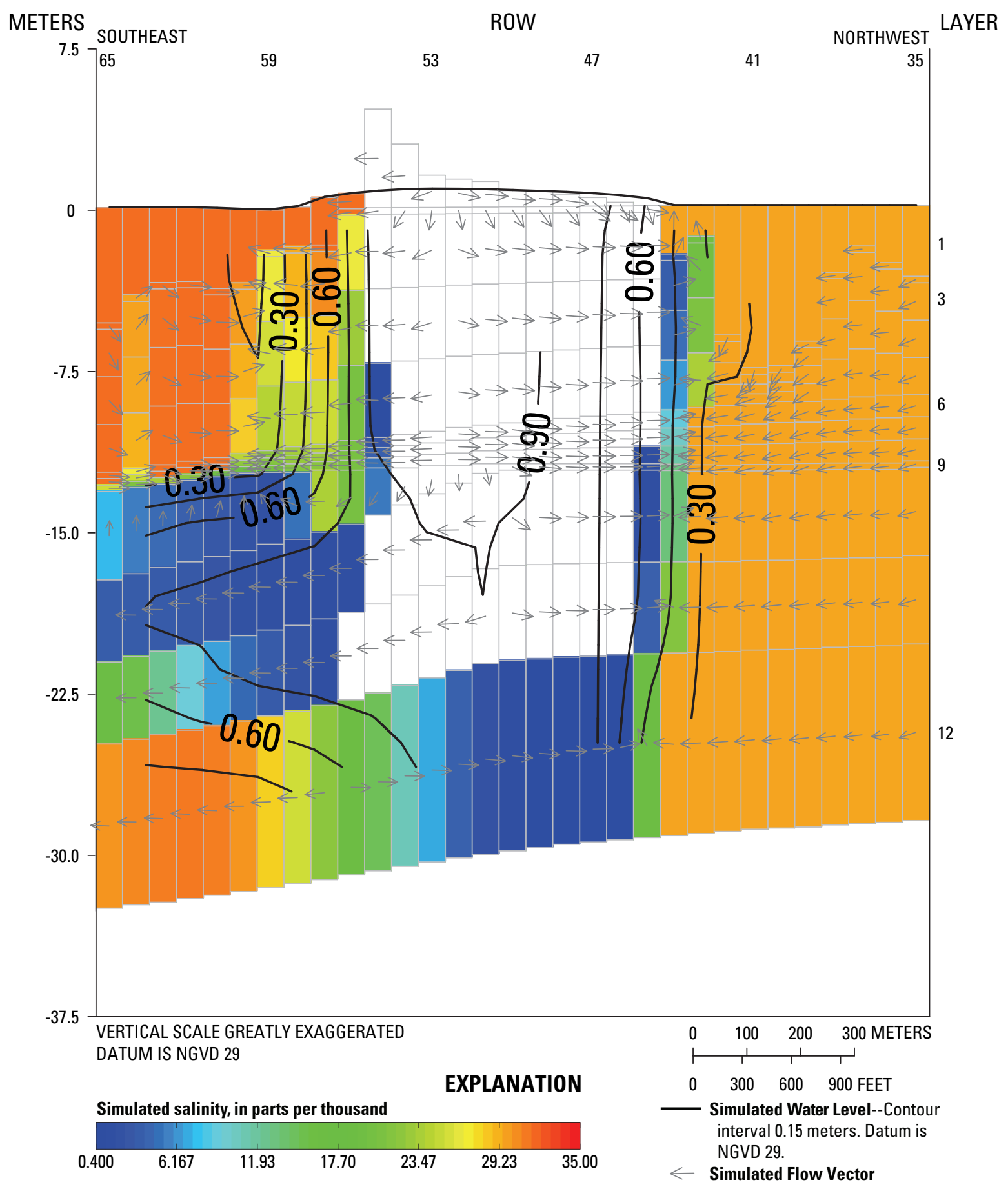

Figure 31. Simulated 2005 mean annual water levels, flow vectors, and extent of freshwater within the shallow aquifer system along four selected columns in the Fire Island study area, Suffolk County, N.Y. (A) column 190, (B) column 255, (C) column 569, and (D) column 790. (Column locations are shown in figure 18. NGVD 29, National Geodetic Vertical Datum of 1929) 


\section{B Column 255}

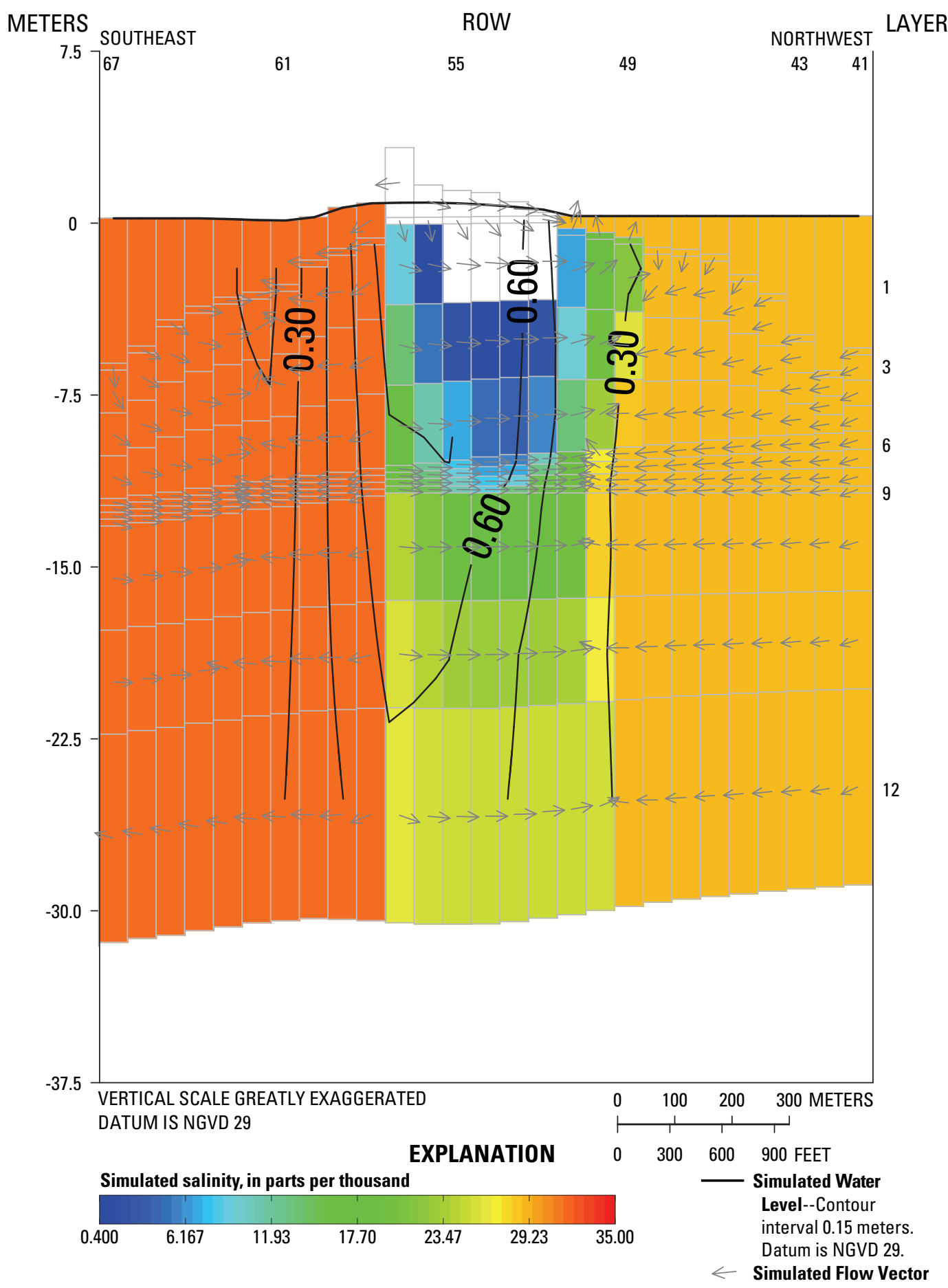

Figure 31. Simulated 2005 mean annual water levels, flow vectors, and extent of freshwater within the shallow aquifer system along four selected columns in the Fire Island study area, Suffolk County, N.Y. (A) column 190, (B) column 255, (C) column 569, and (D) column 790. (Column locations are shown in figure 18. NGVD 29, National Geodetic Vertical Datum of 1929)—Continued 


\section{Column 569}

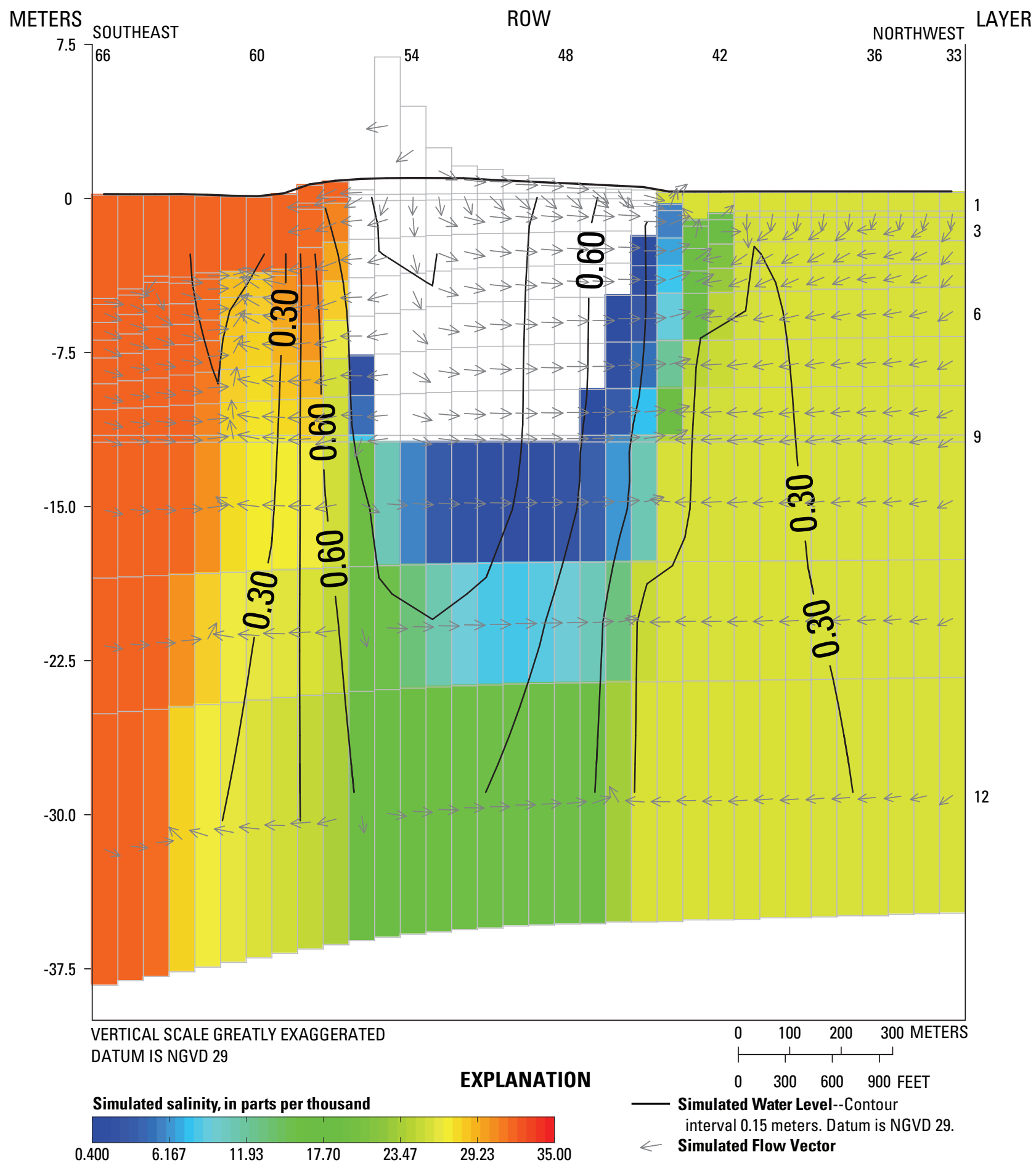

Figure 31. Simulated 2005 mean annual water levels, flow vectors, and extent of freshwater within the shallow aquifer system along four selected columns in the Fire Island study area, Suffolk County, N.Y. (A) column 190, $(B)$ column 255, (C) column 569, and (D) column 790. (Column locations are shown in figure 18. NGVD 29, National Geodetic Vertical Datum of 1929)_Continued 


\section{Column 790}

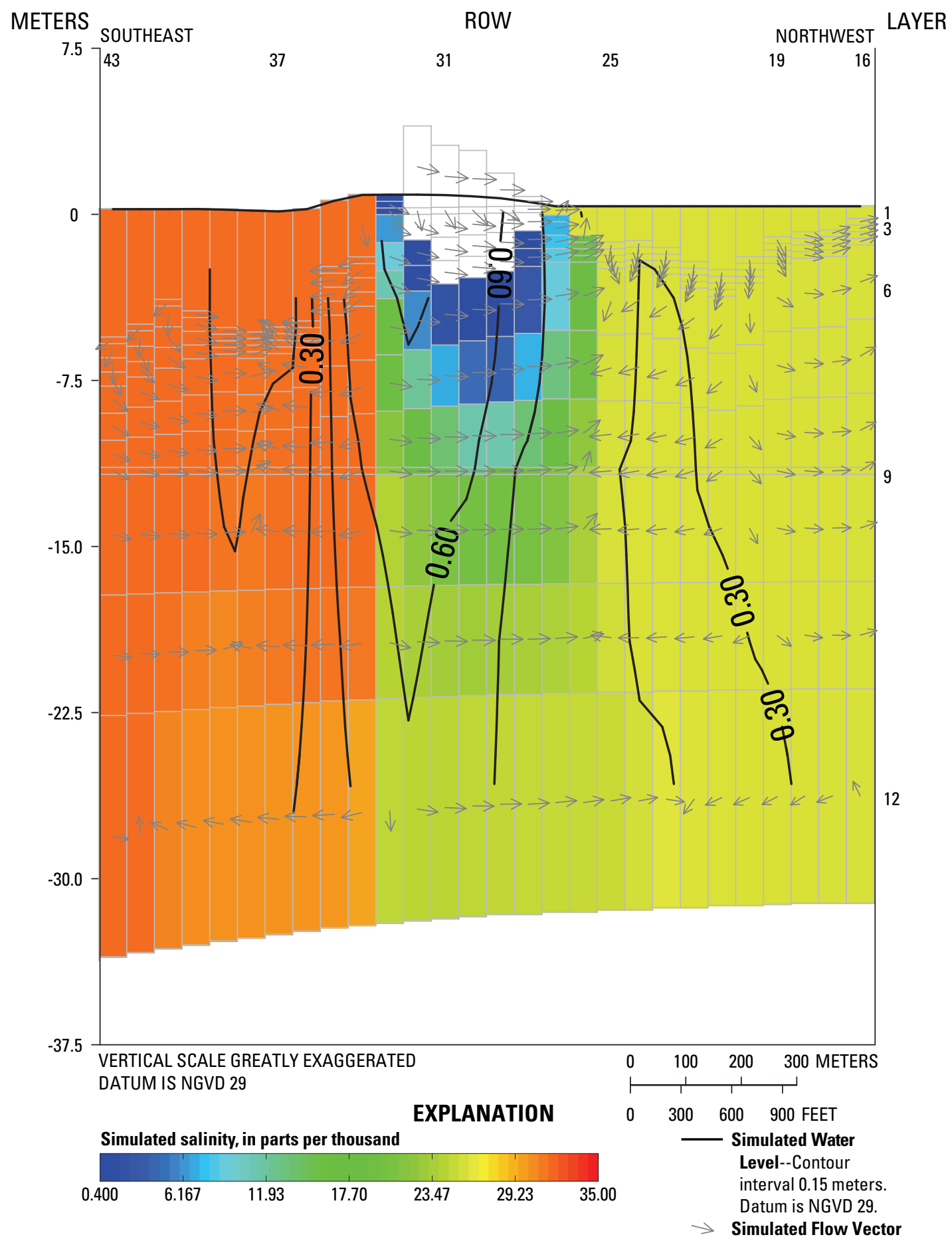

Figure 31. Simulated 2005 mean annual water levels, flow vectors, and extent of freshwater within the shallow aquifer system along four selected columns in the Fire Island study area, Suffolk County, N.Y. (A) column 190, (B) column 255, (C) column 569, and (D) column 790. (Column locations are shown in figure 18. NGVD 29, National Geodetic Vertical Datum of 1929)_Continued 
Table 13. Simulated 2005 mean annual fresh-groundwater budgets for recharge areas of similar land use from the dischargeboundary analysis of Fire Island study area, Suffolk County, N.Y.:

[Contributing-area locations are shown in figure 32]

\begin{tabular}{|c|c|c|c|c|c|c|}
\hline \multirow{3}{*}{$\begin{array}{l}\text { Recharge area } \\
\text { map identifier }\end{array}$} & \multirow{2}{*}{\multicolumn{2}{|c|}{ Inflow, in cubic meters per day }} & \multicolumn{4}{|c|}{ Outflow, in cubic meters per day } \\
\hline & & & \multicolumn{3}{|c|}{ Shoreline discharge zones } & \multirow{2}{*}{$\begin{array}{c}\text { Subsea } \\
\text { discharge zones }\end{array}$} \\
\hline & Total recharge & Lateral flow & Estuary & Ocean & Total & \\
\hline \multicolumn{7}{|c|}{ UNDEVELOPED PARK } \\
\hline 1 & 3,900 & 0 & $-2,440$ & $-1,330$ & $-3,770$ & -124 \\
\hline 3 & 196 & 35 & -179 & -52 & -231 & 0 \\
\hline 4 & 333 & 0 & -278 & -28 & -306 & -27 \\
\hline 6 & 799 & 54 & -636 & -218 & -854 & 0 \\
\hline 8 & 71 & 0 & -45 & 0 & -45 & -26 \\
\hline 10 & 127 & 74 & -149 & -52 & -201 & 0 \\
\hline 17 & 177 & 61 & -238 & 0 & -238 & 0 \\
\hline 19 & 205 & 29 & -234 & 0 & -234 & 0 \\
\hline 26 & 1,250 & 0 & $-1,220$ & 0 & $-1,220$ & -39 \\
\hline 28 & 394 & 0 & -394 & 0 & -394 & 0 \\
\hline 30 & 417 & 74 & -491 & 0 & -491 & 0 \\
\hline 32 & 554 & 54 & -608 & 0 & -608 & 0 \\
\hline 34 & 387 & 5 & -392 & 0 & -392 & 0 \\
\hline 36 & 491 & 0 & -465 & 0 & -465 & -26 \\
\hline 38 & 469 & 0 & -417 & 0 & -417 & -51 \\
\hline 40 & 315 & 93 & -364 & -44 & -408 & 0 \\
\hline 42 & 12,200 & 110 & $-10,300$ & $-2,040$ & $-12,300$ & 0 \\
\hline 44 & 375 & 0 & -138 & -52 & -191 & -185 \\
\hline 46 & 8,270 & 0 & $-8,040$ & 0 & $-8,040$ & -223 \\
\hline Subtotal & 30,900 & 589 & $-27,000$ & $-3,820$ & $-30,800$ & -701 \\
\hline \multicolumn{7}{|c|}{ DEVELOPED PARK } \\
\hline 2 & 6,130 & 0 & $-4,670$ & $-1,150$ & $-5,820$ & -310 \\
\hline 5 & 538 & 0 & -377 & -136 & -514 & -24 \\
\hline 15 & 296 & 0 & -196 & 0 & -196 & -100 \\
\hline 27 & 400 & 0 & -399 & 0 & -399 & -1 \\
\hline 33 & 215 & 0 & -103 & 0 & -103 & -113 \\
\hline 41 & 717 & 0 & -489 & -53 & -542 & -175 \\
\hline 43 & 177 & 15 & -193 & 0 & -193 & 0 \\
\hline 45 & 1,530 & 0 & $-1,510$ & 0 & $-1,510$ & -21 \\
\hline Subtotal & 10,000 & 15 & $-7,940$ & $-1,340$ & $-9,280$ & -744 \\
\hline
\end{tabular}


Table 13. Simulated 2005 mean annual fresh-groundwater budgets for recharge areas of similar land use from the dischargeboundary analysis of Fire Island study area, Suffolk County, N.Y.-Continued

[Contributing-area locations are shown in figure 32]

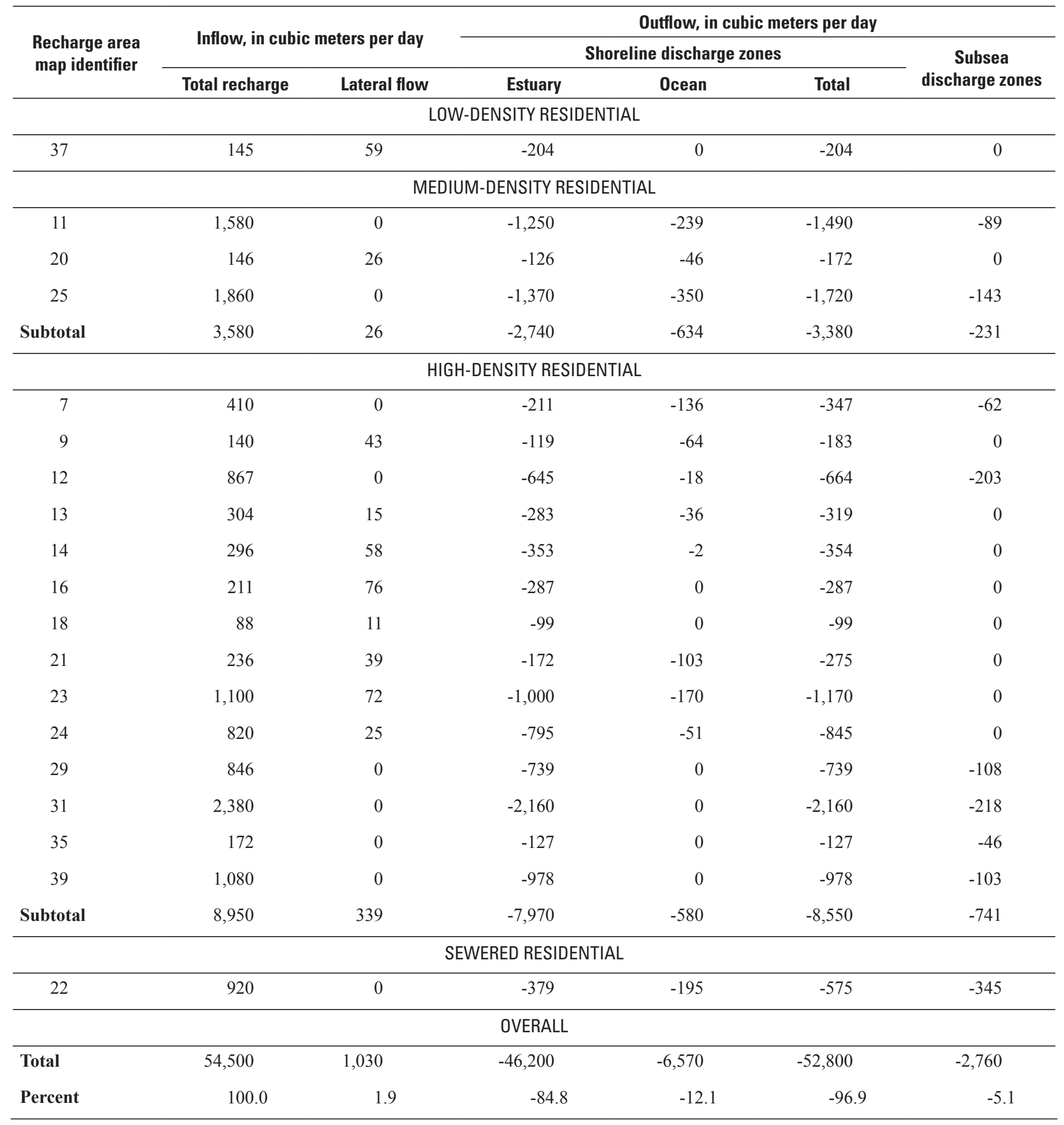



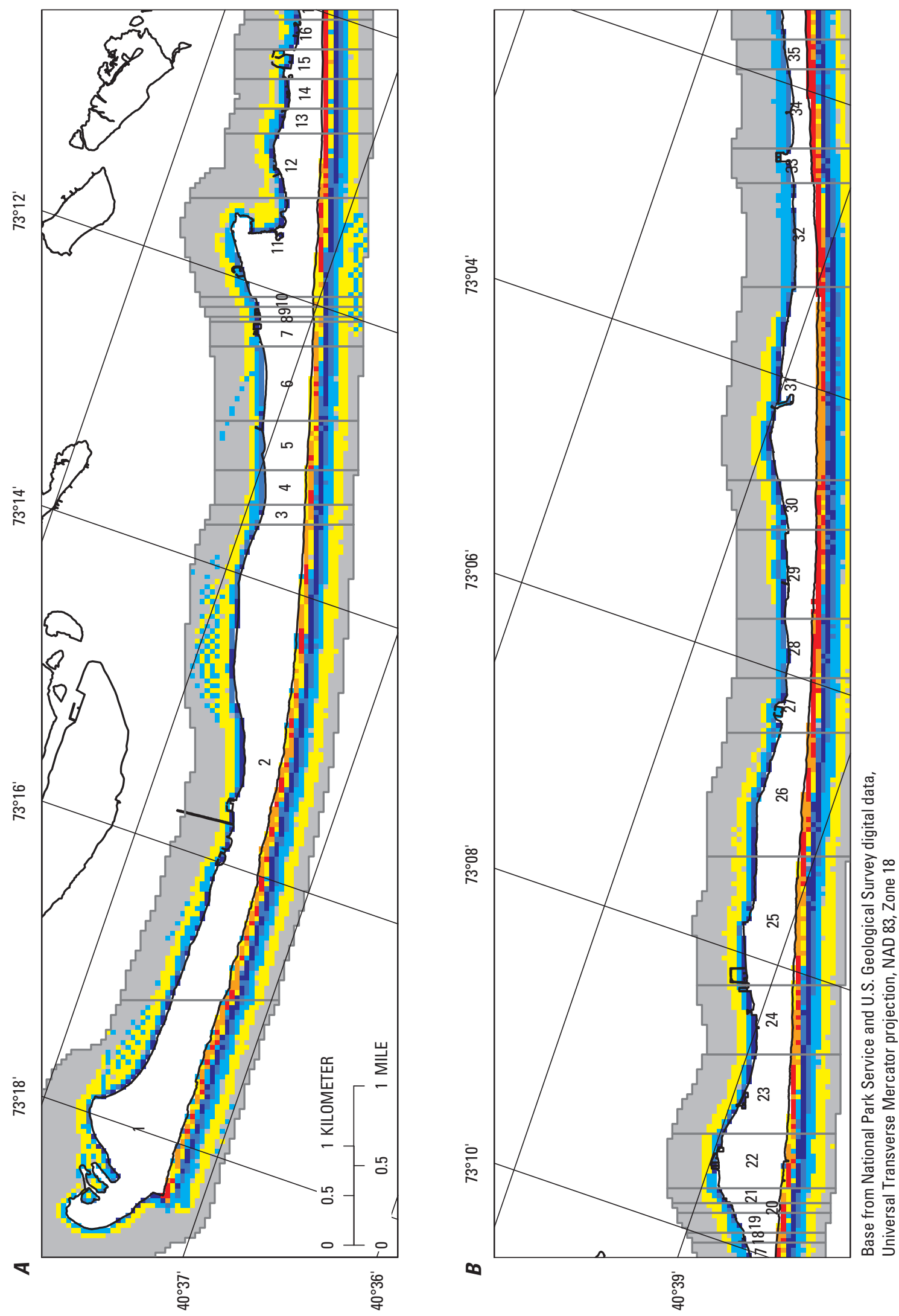

$\frac{1}{\stackrel{d}{L}}$

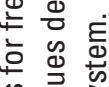

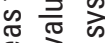

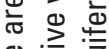

인 菏 지

它选

는

क

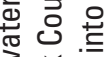

उ 힝

式艺芯

के गु ल

ఏ đัँ

竞

E

它 을

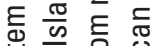

인

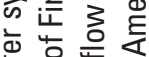

흠 홍흠

त 은은

응 के

的吉盯是

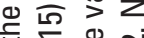

드에

造要

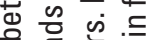

으을

3 $\left.\frac{\pi}{2}\right)^{\frac{\pi}{3}}$

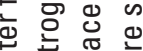

离育売

उ등

至 范

흠 은 ‘

त $\frac{\sigma}{2} \infty$

든

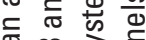

तั ल के त

है \&

유ㅇㅝㅠ 흉

प्ष

立 을 을

๘ 㐫芒

กิ กิ $_{0}^{\pi}$

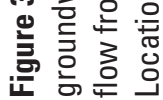



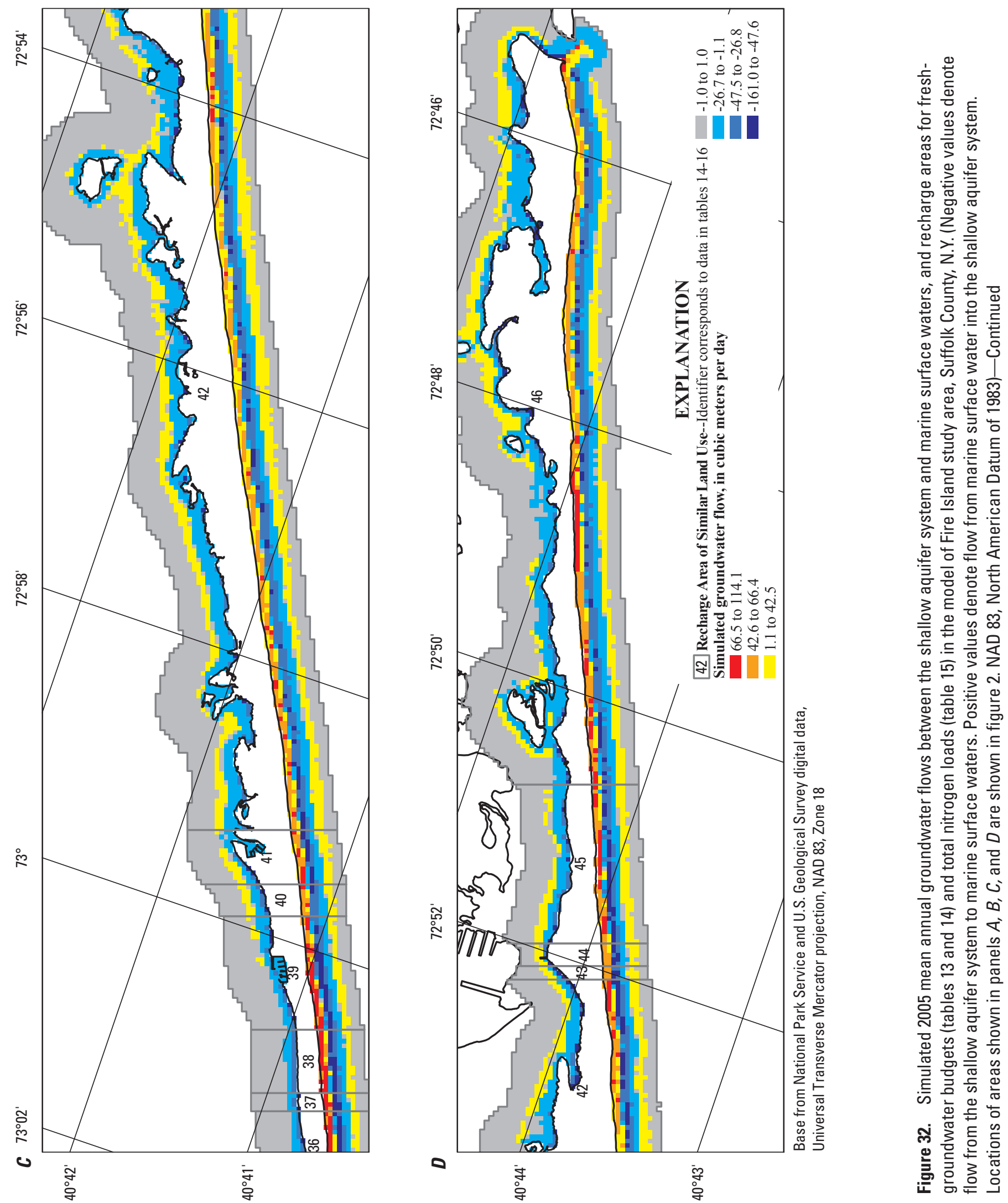
Table 14. Simulated 2005 mean annual fresh-groundwater budgets for recharge areas of similar land use from the contributing-area analysis of Fire Island study area, Suffolk County, N.Y.

[Contributing-area locations are shown in figure 32]

\begin{tabular}{|c|c|c|c|c|c|}
\hline \multirow{3}{*}{$\begin{array}{c}\text { Recharge area } \\
\text { map } \\
\text { identifier }\end{array}$} & \multirow{3}{*}{$\begin{array}{c}\text { Total recharge, } \\
\text { in cubic meters } \\
\text { per day }\end{array}$} & \multicolumn{3}{|c|}{ Outflow, in cubic meters per day } & \multirow{3}{*}{$\begin{array}{c}\text { Subsea } \\
\text { discharge zones }\end{array}$} \\
\hline & & \multicolumn{3}{|c|}{ Shoreline discharge zones } & \\
\hline & & Estuary & Ocean & Total & \\
\hline \multicolumn{6}{|c|}{ UNDEVELOPED PARK } \\
\hline 1 & 3,900 & $-2,570$ & $-1,270$ & $-3,840$ & -63 \\
\hline 3 & 196 & -136 & -59 & -196 & 0 \\
\hline 4 & 333 & -233 & -101 & -333 & 0 \\
\hline 6 & 799 & -555 & -244 & -799 & 0 \\
\hline 8 & 71 & -48 & -23 & -71 & 0 \\
\hline 10 & 127 & -87 & -39 & -127 & 0 \\
\hline 17 & 177 & -177 & 0 & -177 & 0 \\
\hline 19 & 205 & -165 & -40 & -205 & 0 \\
\hline 26 & 1,250 & $-1,060$ & -188 & $-1,250$ & -7 \\
\hline 28 & 394 & -394 & 0 & -394 & 0 \\
\hline 30 & 417 & -381 & -28 & -410 & -7 \\
\hline 32 & 554 & -554 & 0 & -554 & 0 \\
\hline 34 & 387 & -387 & 0 & -387 & 0 \\
\hline 36 & 491 & -491 & 0 & -491 & 0 \\
\hline 38 & 469 & -469 & 0 & -469 & 0 \\
\hline 40 & 315 & -260 & -50 & -310 & -6 \\
\hline 42 & 12,200 & $-9,190$ & $-2,700$ & $-11,900$ & -327 \\
\hline 44 & 375 & -302 & -66 & -368 & -7 \\
\hline 46 & 8,270 & $-7,020$ & $-1,100$ & $-8,120$ & -142 \\
\hline Subtotal & 30,900 & $-24,500$ & $-5,900$ & $-30,400$ & -561 \\
\hline \multicolumn{6}{|c|}{ DEVELOPED PARK } \\
\hline 2 & 6,130 & $-4,620$ & $-1,480$ & $-6,100$ & -35 \\
\hline 5 & 538 & -394 & -144 & -538 & 0 \\
\hline 15 & 296 & -278 & -17 & -296 & 0 \\
\hline 27 & 400 & -400 & 0 & -400 & 0 \\
\hline 33 & 215 & -215 & 0 & -215 & 0 \\
\hline 41 & 717 & -555 & -141 & -696 & -21 \\
\hline 43 & 177 & -155 & -22 & -177 & 0 \\
\hline 45 & 1,530 & $-1,320$ & -179 & $-1,500$ & -27 \\
\hline Subtotal & 10,000 & $-7,940$ & $-1,980$ & $-9,920$ & -83 \\
\hline \multicolumn{6}{|c|}{ LOW-DENSITY RESIDENTIAL } \\
\hline 37 & 145 & -145 & 0 & -145 & 0 \\
\hline \multicolumn{6}{|c|}{ MEDIUM-DENSITY RESIDENTIAL } \\
\hline 11 & 1,580 & $-1,270$ & -283 & $-1,550$ & -27 \\
\hline 20 & 146 & -109 & -36 & -146 & 0 \\
\hline 25 & 1,860 & $-1,370$ & -477 & $-1,840$ & -17 \\
\hline Subtotal & 3,580 & $-2,740$ & -797 & $-3,540$ & -44 \\
\hline
\end{tabular}


Table 14. Simulated 2005 mean annual fresh-groundwater budgets for recharge areas of similar land use from the contributing-area analysis of Fire Island study area, Suffolk County, N.Y.-Continued

[Contributing-area locations are shown in figure 32]

\begin{tabular}{|c|c|c|c|c|c|}
\hline \multirow{3}{*}{$\begin{array}{c}\text { Recharge area } \\
\text { map } \\
\text { identifier }\end{array}$} & \multirow{3}{*}{$\begin{array}{c}\text { Total recharge, } \\
\text { in cubic meters } \\
\text { per day }\end{array}$} & \multicolumn{3}{|c|}{ Outflow, in cubic meters per day } & \multirow{3}{*}{$\begin{array}{c}\text { Subsea } \\
\text { discharge zones }\end{array}$} \\
\hline & & \multicolumn{3}{|c|}{ Shoreline discharge zones } & \\
\hline & & Estuary & Ocean & Total & \\
\hline \multicolumn{6}{|c|}{ HIGH-DENSITY RESIDENTIAL } \\
\hline 7 & 410 & -281 & -129 & -410 & 0 \\
\hline 9 & 140 & -99 & -41 & -140 & 0 \\
\hline 12 & 867 & -693 & -150 & -843 & -24 \\
\hline 13 & 304 & -248 & -57 & -304 & 0 \\
\hline 14 & 296 & -252 & -38 & -291 & -5 \\
\hline 16 & 211 & -211 & 0 & -211 & 0 \\
\hline 18 & 88 & -81 & -7 & -88 & 0 \\
\hline 21 & 236 & -175 & -61 & -236 & 0 \\
\hline 23 & 1,100 & -826 & -232 & $-1,060$ & -41 \\
\hline 24 & 820 & -647 & -164 & -812 & -8 \\
\hline 29 & 846 & -816 & -25 & -841 & -6 \\
\hline 31 & 2,380 & $-2,010$ & -349 & $-2,360$ & -18 \\
\hline 35 & 172 & -172 & 0 & -172 & 0 \\
\hline 39 & 1,080 & $-1,020$ & -45 & $-1,070$ & -13 \\
\hline Subtotal & 8,950 & $-7,530$ & $-1,300$ & $-8,830$ & -116 \\
\hline \multicolumn{6}{|c|}{ SEWERED RESIDENTIAL } \\
\hline 22 & 920 & -648 & -241 & -888 & -31 \\
\hline \multicolumn{6}{|c|}{ OVERALL } \\
\hline Total & 54,500 & $-43,500$ & $-10,200$ & $-53,700$ & -836 \\
\hline Percent & 100.0 & -79.8 & -18.7 & -98.5 & -1.5 \\
\hline
\end{tabular}

\section{Limitations of Analysis}

Several limitations apply to simulations of groundwater discharge and calculations of nitrogen loads.

The total estimate of water-table overheight resulting from wave setup and tidal pumping along the Atlantic Ocean shore of Fire Island relies on simplified terms and probably can be considered a conservative approximation. The estimate also is based on a static shoreline position that in reality is dynamic, due partly to changes in wave climate that also may affect the overheight amount.

Coarse model discretization results in averaging over large spatial and temporal scales and, therefore, limits the precision of simulated groundwater flow patterns and rates and the resulting nitrogen-loading calculations. Because the calibration was limited to groundwater levels, the model is nonunique-variations in hydraulic conductivity and recharge are most likely inversely correlated (an increase in one has the same result on hydraulic head as a decrease in the other). Although no formal sensitivity analysis was done, addition of the water-table overheight condition during model development strongly affected simulated water levels, particularly along the ocean shore. Variations in the no-flow condition specified at the base of the upper glacial aquifer that could allow flow across underlying low-permeability units (the Gardiners Clay and Monmouth greensand) also may affect results, but probably to a lesser extent.

Simulations of variable-density groundwater flow were run to achieve a steady-state extent of freshwater under current (2005) conditions. Although the modeled hydrologic boundaries are assumed to be constant through time, they can undergo significant fluctuations due to storm tides and other short-term factors. For example, the barrier-island aquifer system is periodically recharged by saline groundwater through storm overwash and coastal flooding. As a result, the model probably overestimates the depth of freshwater extent, particularly in deeper, confined zones with longer traveltimes for freshwater recharge. Consequently, transient modeling of historical conditions may be required to better understand how short-term fluctuations in hydrologic boundaries affect groundwater discharge and nitrogen loads. 

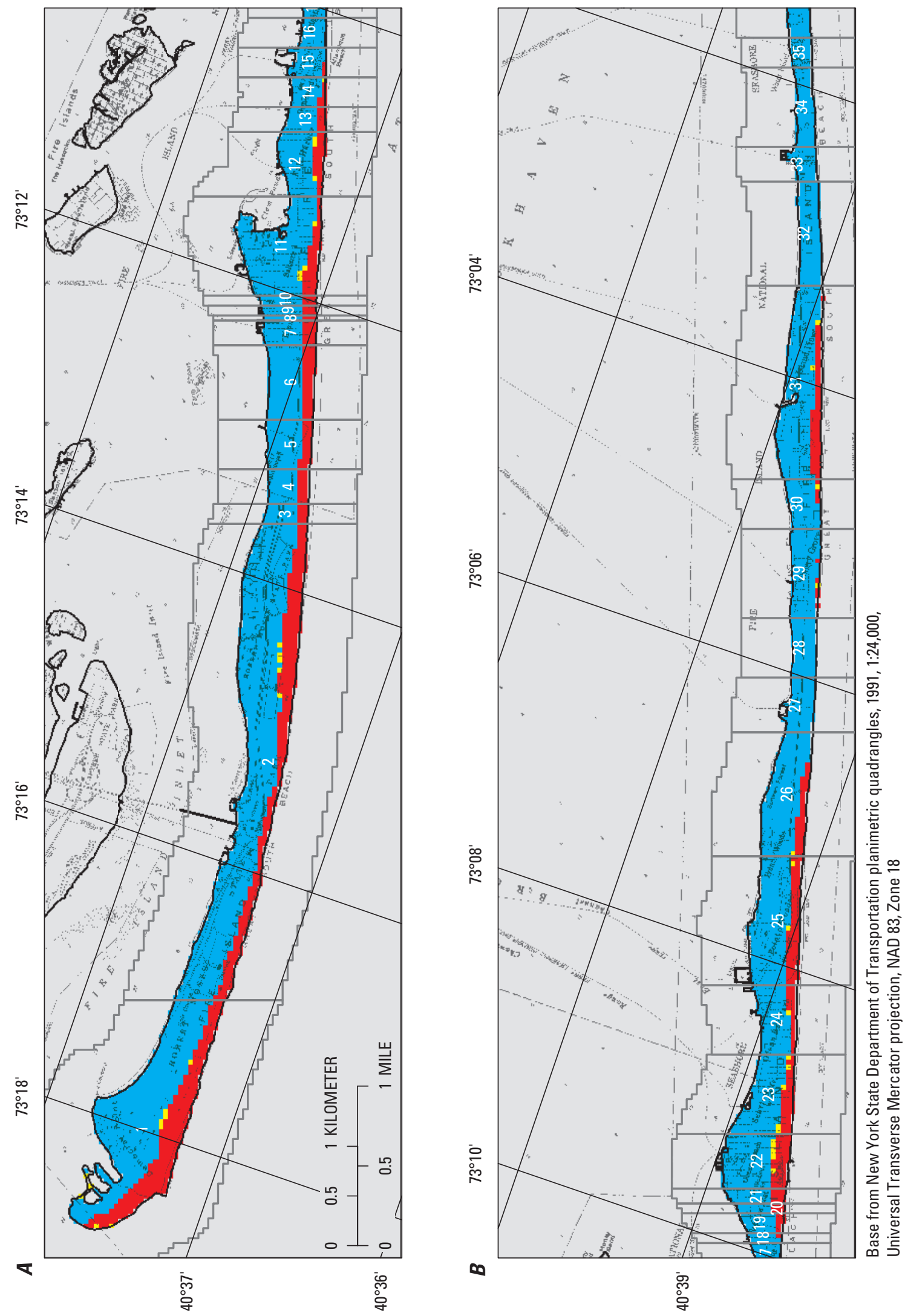

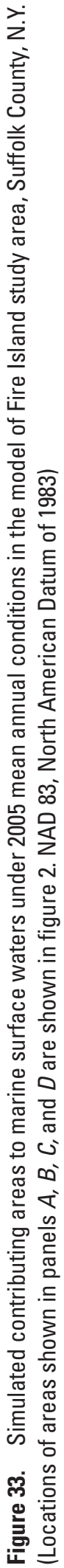



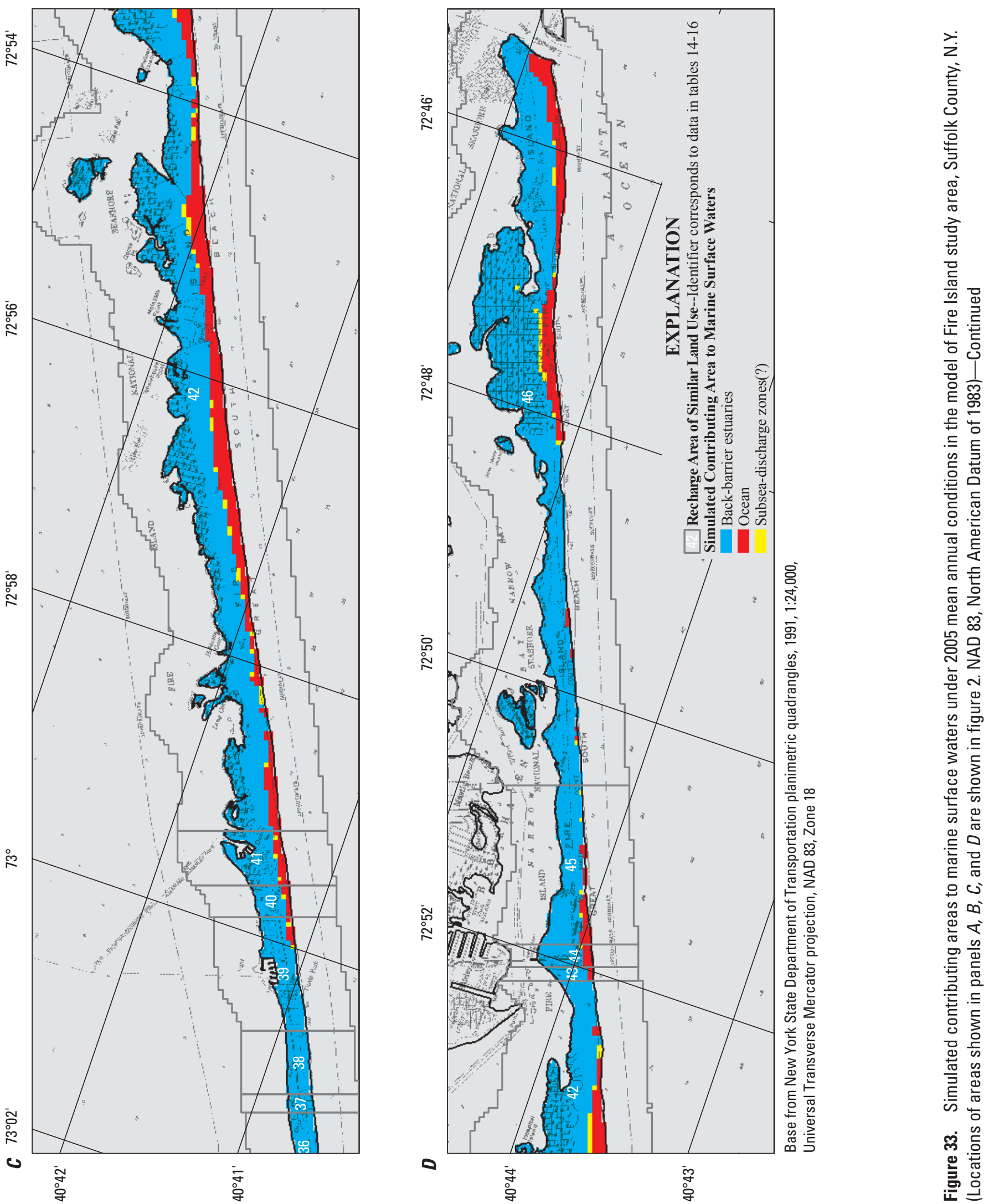
Table 15. Calculated total nitrogen loads to marine surface waters for recharge areas of similar land use in the model of Fire Island study area, Suffolk County, N.Y.

[Contributing-area locations are shown in figure 32. $\mathrm{kg} / \mathrm{yr}$, kilograms per year]

\begin{tabular}{|c|c|c|c|}
\hline \multirow{2}{*}{$\begin{array}{l}\text { Recharge area } \\
\text { map identifier }\end{array}$} & \multicolumn{3}{|c|}{ Total nitrogen load to shoreline discharge zones from fresh ground water, in $\mathrm{kg} / \mathrm{yr}$} \\
\hline & Estuary & Ocean & Total \\
\hline \multicolumn{4}{|c|}{ UNDEVELOPED PARK } \\
\hline 1 & 272 & 134 & 406 \\
\hline 3 & 14 & 6 & 21 \\
\hline 4 & 25 & 11 & 35 \\
\hline 6 & 59 & 26 & 85 \\
\hline 8 & 5 & 2 & 8 \\
\hline 10 & 9 & 4 & 13 \\
\hline 17 & 19 & 0 & 19 \\
\hline 19 & 17 & 4 & 22 \\
\hline 26 & 112 & 20 & 132 \\
\hline 28 & 42 & 0 & 42 \\
\hline 30 & 40 & 3 & 43 \\
\hline 32 & 59 & 0 & 59 \\
\hline 34 & 41 & 0 & 41 \\
\hline 36 & 52 & 0 & 52 \\
\hline 38 & 50 & 0 & 50 \\
\hline 40 & 28 & 5 & 33 \\
\hline 42 & 973 & 286 & 1,260 \\
\hline 44 & 32 & 7 & 39 \\
\hline 46 & 744 & 116 & 860 \\
\hline Subtotal & 2,590 & 625 & 3,220 \\
\hline \multicolumn{4}{|c|}{ DEVELOPED PARK } \\
\hline 2 & 2,750 & 881 & 3,630 \\
\hline 5 & 235 & 86 & 320 \\
\hline 15 & 166 & 10 & 176 \\
\hline 27 & 238 & 0 & 238 \\
\hline 33 & 128 & 0 & 128 \\
\hline 41 & 330 & 84 & 415 \\
\hline 43 & 92 & 13 & 106 \\
\hline 45 & 788 & 106 & 895 \\
\hline Subtotal & 4,730 & 1,180 & 5,910 \\
\hline \multicolumn{4}{|c|}{ LOW-DENSITY RESIDENTIAL } \\
\hline 37 & 63 & 0 & 63 \\
\hline \multicolumn{4}{|c|}{ MEDIUM-DENSITY RESIDENTIAL } \\
\hline 11 & 551 & 123 & 674 \\
\hline 20 & 47 & 16 & 63 \\
\hline 25 & 594 & 207 & 801 \\
\hline Subtotal & 1,190 & 346 & 1,540 \\
\hline
\end{tabular}


Table 15. Calculated total nitrogen loads to marine surface waters for recharge areas of similar land use in the model of Fire Island study area, Suffolk County, N.Y.-Continued

[Contributing-area locations are shown in figure 32. $\mathrm{kg} / \mathrm{yr}$, kilograms per year]

\begin{tabular}{rrrr}
\hline \multirow{2}{*}{$\begin{array}{c}\text { Recharge area } \\
\text { map identifier }\end{array}$} & \multicolumn{3}{c}{ Total nitrogen load to shoreline discharge zones from fresh ground water, in $\mathbf{~ k g} / \mathbf{y r}$} \\
\cline { 2 - 4 } & Estuary & Ocean & Total \\
\hline 7 & 276 & HIGH-DENSITY RESIDENTIAL & \\
9 & 97 & 126 & 403 \\
12 & 681 & 147 & 138 \\
13 & 243 & 56 & 828 \\
14 & 248 & 38 & 299 \\
16 & 207 & 0 & 286 \\
18 & 79 & 7 & 207 \\
21 & 172 & 60 & 86 \\
23 & 812 & 228 & 232 \\
24 & 636 & 161 & 1,040 \\
29 & 801 & 25 & 797 \\
31 & 1,970 & 342 & 826 \\
35 & 169 & 0 & 2,320 \\
39 & 1,000 & 45 & 169 \\
Subtotal & 7,400 & 1,280 & 1,050 \\
\hline \multicolumn{5}{c}{} \\
\hline
\end{tabular}

Table 16. Annual totals and rates of nitrogen loading from shallow groundwater to marine surface waters from three watersheds on Long Island, N.Y.

[ $\mathrm{km}^{2}$, square kilometers; $\mathrm{kg}$, kilograms; $\mathrm{kg} / \mathrm{km}^{2}$, kilograms per square kilometer]

\begin{tabular}{|c|c|c|}
\hline \multirow{2}{*}{$\begin{array}{c}\text { Watershed } \\
\text { area, } \\
\text { in } \mathbf{k m}^{2}\end{array}$} & \multicolumn{2}{|c|}{ Annual nitrogen loading from shallow groundwater to marine surface waters } \\
\hline & Total, in kg & Rate, in $\mathrm{kg} / \mathrm{km}^{2}$ \\
\hline \multicolumn{3}{|c|}{ FIRE ISLAND' } \\
\hline 22 & 19,700 & ${ }^{2} 890$ \\
\hline \multicolumn{3}{|c|}{ SOUTH SHORE ESTUARY RESERVE STUDY AREA ${ }^{3}$} \\
\hline 1,420 & 501,000 & 353 \\
\hline \multicolumn{3}{|c|}{ NORTH SHORE OF LONG ISLAND ${ }^{4}$} \\
\hline 927 & 425,000 & 458 \\
\hline \multicolumn{3}{|c|}{${ }^{1}$ As mapped by Klopfer and others (2002). } \\
\hline \multicolumn{3}{|c|}{${ }^{2}$ Amount may not equal the sum of values because of rounding to significant digits. } \\
\hline \multicolumn{3}{|c|}{${ }^{3}$ As defined by Monti and Scorca (2003). } \\
\hline${ }^{4}$ As defined & d Monti (2001). & \\
\hline
\end{tabular}


Use of the TN concentrations to calculate nitrogen loads may overestimate mass-loading rates through the assumption of conservative transport in groundwater. Additional uncertainties in nitrogen loads from residential areas on Fire Island include (1) estimation of TN concentrations using values calculated by Monti and Scorca (2003) for the southern Suffolk County mainland, and (2) reliance on $\mathrm{TN}$ concentrations from four wells downgradient from two communities to assess the suitability of these surrogate values.

\section{Groundwater-Resource Concerns}

Although high-density residential land use occupies only about 8 percent of Fire Island, its unsewered areas contribute almost half of the overall TN load from the shallow aquifer system to back-barrier estuaries.

Because of the combined effects of wave setup and tidal pumping along the ocean shore, the resulting water-table overheight directs about 80 percent of freshwater recharge on Fire Island to back-barrier estuaries. As a result, groundwaterprotection strategies need to consider most of the island as a potential source area to the wetland and adjacent estuarine habitats within the boundaries of FIIS.

Water-quality sampling conducted during this study typically showed very low TN concentrations in undeveloped park areas. However, TN concentrations were elevated locally in these areas that were downgradient from at least two communities - Kismet and Robbins Rest—and from the Watch Hill leach field. Although the elevated concentrations were within the range of those commonly measured in developed areas of the Long Island mainland, they exceeded the background (natural) levels observed in undeveloped park areas at FIIS by a factor of 10 or more. This considerable increase in $\mathrm{TN}$ concentrations associated with human activities may have important consequences for terrestrial and aquatic (freshwater and brackish) species adapted to the low nutrient levels generally within and downgradient from these undeveloped areas.

Elevated nutrient concentrations in groundwater underlying undeveloped areas indicate that recharge containing sewage, fertilizers, and (or) other human products has infiltrated the water table in upgradient areas. This contaminated recharge could also contain pathogens and other human-derived substances such as organic compounds that can move through the shallow aquifer and, in turn, threaten the ecological health of downgradient aquatic and coastal habitats.

\section{Use of Long-Term Monitoring to Assess Water Resources}

Natural groundwater discharge sustains ponds, wetlands, and salinity in back-barrier estuaries at FIIS. Knowledge of the quantity and quality of groundwater flow is an essential step in evaluating the availability and suitability of water for aquatic ecosystems (Schubert and others, 1997). Furthermore, long-term hydrologic monitoring is critical for understanding the effects of stresses on the groundwater system and on the freshwater and estuarine ecosystems that depend on it (McCobb and Weiskel, 2003).

The network of shallow observation wells installed at FIIS during this study is to be used in a long-term program of groundwater-level and water-quality-sample collection. The groundwater monitoring protocol established by the USGS for the Cape Cod National Seashore Long-Term Ecosystem Monitoring Program (McCobb and Weiskel, 2003) provides a guide for the implementation of the groundwater-level monitoring program. The National Field Manual for the Collection of Water-Quality Data (U.S. Geological Survey, variously dated) describes USGS-accepted methods for water-quality data collection that form the basis for the waterquality-sampling program.

\section{Groundwater Levels}

Groundwater levels are an intrinsic indicator of the quantity of water in an aquifer system and of the ability of water and chemicals to enter, transit, and exit this system. The minimum measurement frequency of groundwater levels is dependent on the factor(s) of interest. Yearly measurements may be adequate to describe inter-annual changes in aquifer conditions caused by climate variability; however, monthly measurements typically are required to characterize seasonal variations. Continuous recorders that collect measurements several times an hour can document groundwater fluctuations caused by the tides and by short-term changes in other factors such as natural recharge, wastewater disposal, and wave climate. The optimal network design would utilize a range of measurement intervals to address the monitoring objectives efficiently.

In this study, the directions of fresh groundwater movement throughout FIIS were controlled primarily by the combined effect of wave setup and tidal pumping, which together result in a water-table overheight condition along the ocean shore. Thus, monitoring intended to assess long-term changes in this movement would need to include groundwater measurements collected continuously to resolve short-term fluctuations caused by these factors. Moreover, because the shallow aquifer system contains a relatively minor amount of freshwater storage that can buffer these fluctuations, shortterm and seasonal (between summer and winter) water-table variations may equal or exceed annual and longer-term changes. As a result, monitoring resources would probably be used most beneficially if they were allocated primarily to a relatively small number of sites measured at comparatively high frequencies.

Operating at least two continuous water-level recorders at FIIS would help resolve short-term water-table fluctuations in the barrier-island groundwater flow system. One recorder could be situated in a developed area to evaluate the effects of urbanization on groundwater resources; the other could be in an area isolated from the effects of development. Water-table 
observation wells S125986 in Kismet and S125364 in the National Wilderness (fig. 4) essentially fulfill these requirements, and the water levels in these wells have been monitored continuously since October 2005 (figs. 15A and D).

Seasonal variations in the directions of groundwater flow could be characterized through the monthly measurement of water levels at a pair of water-table observation wells downgradient from each recorder well. These measurements would be made at wells near ocean and estuary discharge locations and together with the recorder well would form a water-table transect that could be used to identify changes in the patterns and rates of groundwater flow to coastal habitats caused by barrier-island and inlet dynamics, climate change, and sea-level rise. In the Kismet vicinity of recorder well S125986, observation wells S125371 and S125370 are closest to the marine surface waters along this transect, as are wells S125363 and S125365 in the National Wilderness vicinity of recorder well S125364 (fig. 4).

Long-term changes in the regional patterns and rates of groundwater flow caused by climatic fluctuations could be monitored by collecting yearly water-level measurements at three observation wells in each of the remaining local study areas. Monitoring could be conducted along a watertable transect between the ocean and estuary in Robbins Rest at wells S125994, S125982, and S125996 and along a comparable transect in Watch Hill at wells S125380, S125383, and S125387 (fig. 4). Overall, continuous, monthly, and annual water-level monitoring would encompass a network of 12 wells that bisects Fire Island at four locations and quantifies the condition of the aquifer system along a continuum of time scales.

\section{Water-Quality Samples}

Water samples provide a discrete measure of the quality of water in an aquifer system and of the occurrence and distribution of chemical constituents transported by water through the system. Information on the presence of potential contamination within an aquifer system is determined by the suite of constituents chosen for collection and analysis. These constituents can be fixed during repeated sampling to assess changes in concentrations of selected constituents over time or can be varied to investigate multiple classes of contaminants during the same period. The approach taken in a sampling program depends on the chemical properties of a given constituent, the manner and rate at which this constituent may be introduced to the hydrologic system, and the potential interaction of these properties with other factors spatially and temporally within this system.

Nutrient concentrations sampled during this study were low in undeveloped park areas but elevated locally in areas downgradient from communities and from the NPS facility at Watch Hill. Therefore, monitoring focused on detecting long-term changes in these concentrations would need to include water samples collected from developed and undeveloped areas to recognize nutrient contamination from sewage, fertilizers, and (or) other human products. These point and nonpoint sources of contamination could include pathogens and other human-derived substances such as organic compounds. To begin developing a database of occurrences for these and other contaminants, the monitoring program would need to focus on a variety of constituent suites. Alternatively, collection of water samples from within the communities themselves to better understand the occurrence and distribution of elevated nutrient concentrations and other potential contaminants would be quite useful. As a result, the water-quality monitoring program should consider having a contingency for the future installation and sampling of additional wells in these areas.

To monitor long-term changes in nutrient concentrations within groundwater recharge and discharge, annual water samples would need to be collected and analyzed for this constituent grouping from at least two observation wells in each of the four local study areas. Sampling could be conducted in the interior of the island at the deep watertable observation well-from which nutrient concentrations representative of upgradient land use have previously been measured - and at the shallow well situated near the estuary discharge location in each area. These wells include S126753 and S125370 in Kismet, S126000 and S125996 in Robins Rest, S125990 and S125387 in Watch Hill, and S125369 and S125365 in the National Wilderness (fig. 4). Collection of physical characteristics (for example, specific conductance) during sampling of the deep wells would provide additional information that could be used to indicate the movement of the freshwater-saltwater transition zone caused by climate change, sea-level rise, and changes in water use.

The annual collection and analysis of water samples for nutrient concentrations could also include monitoring for the occurrence of organic compounds. A different suite of constituents could be targeted each year during a 3 -year cycle. Year 1 could examine a range of pesticides using extremely low (parts per trillion) detection limits and volatile organic compounds. The second year could focus on assessing wastewater compounds and an alternate group of low-level (parts per trillion) pesticides. Year 3 could evaluate pharmaceuticals and other hormone-mimicking compounds. At the conclusion of the 3-year cycle, the need to monitor these and other types of emerging contaminants could be re-assessed and updated to improve the efficacy of future monitoring efforts.

\section{Summary}

Fire Island National Seashore (FIIS) occupies $42 \mathrm{~km}$ of the barrier island for which it is named that lies off the southern shore of western and central Suffolk County, Long Island, N.Y. Interspersed throughout FIIS are 17 pre-existing residential beach communities that in summer months greatly increase in population through the arrival of summer residents 
and vacationers. In addition, the National Park Service (NPS) has established several facilities on the island to accommodate visitors to the National Seashore.

Untreated wastewater from the numerous homes and businesses in the barrier-island communities generally is discharged directly into the shallow (water table) aquifer through use of private septic systems and cesspools; wastewater from the NPS facilities also enters this reservoir through leach fields and cesspools. Contaminants entering the groundwater system can pose a threat to coastal habitats, as they are transported by groundwater that discharges to coastal water bodies. The boundary of FIIS extends roughly $1 \mathrm{~km}$ into the back-barrier estuaries of Great South Bay, Narrow Bay, and Moriches Bay. Within this zone, there are extensive areas of seagrass habitat, shellfish and finfish resources, and intense recreational activity. To better understand and protect park natural resources, it is critical to determine the concentration and movement of nutrients and other contaminants being introduced into the shallow groundwater system and transported by freshwater that ultimately discharges to the surrounding coastal waters.

In 2004, the U.S. Geological Survey (USGS), in cooperation with the NPS, began a 3-year investigation to (1) collect groundwater levels and water-quality samples, (2) develop a three-dimensional model of the shallow aquifer system and adjacent marine surface waters, and (3) calculate nitrogen loads in simulated groundwater discharges from the aquifer to back-barrier estuaries and the ocean.

The shallow aquifer system was characterized from the results of exploratory drilling, geophysical surveying, waterlevel monitoring, and water-quality sampling conducted during this study. The investigation focused on four areasthe communities of Kismet and Robbins Rest, the NPS Visitor Center at Watch Hill, and the undeveloped Otis Pike Fire Island High Dune Wilderness. Thirty-five observation wells were installed within FIIS to characterize subsurface hydrogeology and establish a water-table monitoring network in the four study areas.

Fire Island is underlain by a complex aquifer system consisting of unconsolidated glacial, lacustrine, deltaic, and marine deposits of clay, silt, sand, and gravel that range in age from Late Cretaceous to Holocene. These deposits overlie a southward-sloping basement complex of crystalline bedrock of Precambrian and (or) Paleozoic age. Fresh groundwater in the shallow aquifer system on Fire Island is contained within a hydraulically isolated freshwater flow system that extends through the Holocene and Pleistocene hydrogeologic units. This freshwater flow system is bounded laterally by marine surface waters and at depth by saline groundwater.

Three sets of water-level altitudes were collected at all wells to depict the distribution of hydraulic head and provide data for flow-model calibration. One well in each of four local study areas was instrumented with a continuous water-level recorder to document groundwater fluctuations caused by natural recharge, tides, and other factors such as wave height and wastewater disposal. The water levels in all wells generally increased with proximity to the ocean shore; the highest values are at wells nearest the ocean or those just inland. Water levels in inland wells also increased with barrier-island width. These results indicate the groundwater divide of the island is skewed strongly toward the ocean shore, apparently because of the combined effects of wave setup and tidal pumping and the resulting water-table overheight along this shore.

Water samples were collected from 35 observation wells to determine the spatial distribution of total nitrogen (TN) concentrations from wastewater and natural sources. A subset of these wells was resampled to assess the seasonal variability of TN concentrations. The highest TN concentrations - up to $10 \mathrm{mg} / \mathrm{L}$ - were downgradient from the Watch Hill leach field; the lowest-less than $0.1 \mathrm{mg} / \mathrm{L}$ - were within the National Wilderness. The primary form of nitrogen in groundwater from wells near Kismet and Robbins Rest varied between ammonia and nitrate. Ammonia was the primary form in the vicinity of Watch Hill, whereas nitrate predominated within the National Wilderness.

The analysis of the shallow groundwater flow system at FIIS entailed the development of a three-dimensional model of the shallow aquifer system and adjacent marine surface waters to simulate groundwater flow patterns and rates. Development of the variable-density flow model included the construction of the model grid and the assignment of appropriate boundary conditions and aquifer properties. The model was calibrated to observed water levels. Nitrogen loads from the shallow aquifer system were calculated from TN concentrations and simulated groundwater discharges to back-barrier estuaries and the ocean.

The model simulates steady-state groundwater flow directions, velocities, and discharge rates under 2005 mean annual conditions in the shallow aquifer system. Simulated hydraulic heads in the unconfined and underlying confined flow systems generally increase with proximity to the ocean shore, where the modeled effects of wave setup and tidal pumping result in a water-table overheight. The simulated groundwater divide is skewed strongly toward the ocean shore in response to the modeled water-table overheight; it also extends virtually to the base of the shallow aquifer system. Where the modeled barrier island is sufficiently wide to yield elevated hydraulic heads, the groundwater divide originates within the freshwater flow system, which probably restricts the exchange of subsurface flow between back-barrier estuaries and the ocean. Where the barrier island is relatively narrow and heads are comparatively lower, however, the divide originates along the ocean shore, which presumably enhances downward movement of saline water that may subsequently migrate beneath the freshwater flow system to back-barrier estuaries.

Groundwater discharges to these water bodies were estimated through discharge-boundary and contributingarea analyses. Results of the discharge-boundary analysis are consistent with the conceptual and numerical model of barrier-island groundwater flow. Uncertainties in the 
discharge-boundary estimates, however, suggest they probably should be considered qualitative approximations of freshwater flow. Areas that contribute recharge to back-barrier estuaries and the ocean are the only sources of freshwater discharge from the shallow aquifer system and were estimated by flow-based particle tracking. These contributing areas were defined by the forward-tracking of individual particles placed at the center of each model cell receiving recharge. The divide between simulated areas that contribute recharge to backbarrier estuaries and the ocean is skewed strongly toward the ocean shore, where the modeled effects of wave setup and tidal pumping result in the water-table overheight. Simulated areas that do not contribute recharge to these water bodies are assumed to provide a source of freshwater that may exit as subsea underflow.

Groundwater budgets were developed on the basis of results of the contributing-area analysis for recharge areas of similar land use that contribute freshwater to back-barrier estuaries, the ocean, and subsea-discharge zones. These budgets indicate that total freshwater discharge from the shallow aquifer system is about $43,500 \mathrm{~m}^{3} / \mathrm{d}$ (79.8 percent) to back-barrier estuaries and about $10,200 \mathrm{~m}^{3} / \mathrm{d}$ (18.7 percent) to the ocean; about $836 \mathrm{~m}^{3} / \mathrm{d}$ (1.5 percent) may exit the system as subsea underflow. The total contribution of fresh groundwater to shoreline discharge zones amounts to about $53,700 \mathrm{~m}^{3} / \mathrm{d}$ (98.5 percent) — nearly the same as that resulting from the discharge-boundary analysis, which is about $52,800 \mathrm{~m}^{3} / \mathrm{d}$ (96.9 percent). In contrast to the generally consistent budget estimate for estuary zones from the discharge-boundary analysis, which is about $46,200 \mathrm{~m}^{3} / \mathrm{d}$ ( 84.8 percent), the ocean and subsea-discharge zone estimates from this analysis are only somewhat comparable, amounting to about 6,570 (12.1 percent) and 2,760 $\mathrm{m}^{3} / \mathrm{d}$ (5.1 percent), respectively.

The contributing-area analysis also provided estimates of the traveltimes for individual particles from their point of recharge at the water table to their point of discharge at the shore. Results of particle-traveltime tracking indicate the median age of freshwater discharged to back-barrier estuaries and the ocean was 3.4 years, and the $95^{\text {th }}$-percentile age was 20 years.

Simulated groundwater discharges were multiplied by $\mathrm{TN}$ concentrations in recharged water to calculate nitrogen loads to back-barrier estuaries and the ocean. The nitrogen concentrations in undeveloped and developed park areas on Fire Island are assumed to be 0.29 and $1.63 \mathrm{mg} / \mathrm{L}$ as $\mathrm{N}$, respectively. These are median $\mathrm{TN}$ concentrations in groundwater from 16 shallow wells -7 in undeveloped and 9 in developed park areas - sampled in October 2005. Nitrogen concentrations for the residential communities within FIIS are presumed to be comparable to median TN concentrations previously published for the southern, mainland coastline of Suffolk County. For communities consisting mainly of low- to medium-density residential development, the nitrogen concentration is estimated in this study to be generally equivalent to a median TN concentration of $1.19 \mathrm{mg} / \mathrm{L}$. The concentration of TN in communities consisting primarily of high-density residential development is estimated to be generally equivalent to a median value of $2.69 \mathrm{mg} / \mathrm{L}$. For the sewered community of Ocean Beach, the concentration is estimated to be generally equivalent to a median TN value of $0.86 \mathrm{mg} / \mathrm{L}$. Total nitrogen concentrations from four wells downgradient from two communities sampled during this study show reasonable agreement with the previously published values; therefore, the values from the southern Suffolk County mainland probably can be considered reasonable approximations of the median TN concentrations within the Fire Island communities.

The TN concentrations and loads under 2005 mean annual conditions for areas that contribute fresh groundwater to back-barrier estuaries and the ocean were calculated for the principal land uses on Fire Island. Results indicate that the overall TN load from the shallow aquifer system to shoreline discharge zones is about $16,200 \mathrm{~kg} / \mathrm{yr}$ ( 82.2 percent) to back-barrier estuaries and about $3,500 \mathrm{~kg} / \mathrm{yr}$ (17.8 percent) to the ocean. Overall TN loads to estuary zones are about 2,590 (16.0 percent) and 4,730 kg/yr (29.2 percent) from undeveloped and developed park areas, respectively; about 63 (0.4 percent), 1,190 (7.3 percent), and 7,400 kg/yr (45.7 percent) from unsewered residential areas of low, medium, and high density, respectively; and about $203 \mathrm{~kg} / \mathrm{yr}$ (1.3 percent) from the sewered residential area.

The overall TN load from Fire Island to marine surface waters amounts to about $19,700 \mathrm{~kg} / \mathrm{yr}$-roughly 6 percent of the annual TN load from shallow groundwater entering the South Shore Estuary Reserve (SSER) from the Suffolk County mainland, which is about $345,000 \mathrm{~kg} / \mathrm{yr}$. In contrast to the TN load from shallow groundwater for the entire $1,420-\mathrm{km}^{2}$ SSER study area, which annually yields about $353 \mathrm{~kg}$ of nitrogen per square kilometer of watershed, the overall TN load from Fire Island produces nitrogen at an annual rate of about $890 \mathrm{~kg} / \mathrm{km}^{2}$ — more than double the loading rate from shallow groundwater to the SSER from the southern mainland of Nassau and Suffolk Counties. Similarly, the loading rate for Fire Island is nearly twice the annual rate of nitrogen loading from shallow groundwater entering Long Island Sound from the North Shore of Long Island, which is about $458 \mathrm{~kg} / \mathrm{km}^{2}$.

The results of this study have identified several factors that may affect groundwater-resource management within the park. Although high-density residential land use occupies only about 8 percent of Fire Island, the unsewered areas contribute almost half of the overall TN load from groundwater to backbarrier estuaries. Because of the effects of wave setup and tidal pumping along the ocean shore, groundwater protection strategies need to consider most of the island as a potential source area to the wetland and adjacent estuarine habitats within the boundaries of FIIS. TN concentrations in the park downgradient from at least two communities - Kismet and Robbins Rest - and from the Watch Hill leach field exceeded the background (natural) levels observed in other undeveloped park areas at FIIS by a factor of 10 or more. This considerable increase in TN concentrations associated with human activities may have important consequences for species adapted to the 
low nutrient levels generally within and downgradient from these undeveloped areas. The elevated nutrient concentrations indicate that recharge containing sewage, fertilizers, and (or) other human products has infiltrated the water table in upgradient areas and could also contain pathogens and other human-derived substances such as organic compounds that could move through the shallow aquifer and in turn threaten the ecological health of downgradient aquatic and coastal habitats.

Natural groundwater discharge sustains ponds, wetlands, and salinity in back-barrier estuaries at FIIS; long-term hydrologic monitoring is critical for understanding the effects of stresses on the groundwater system and on the freshwater and estuarine ecosystems that depend on it. Continuous, monthly, and annual water-level monitoring to quantify the condition of the aquifer system along a continuum of time scales could be accomplished through a network of 12 wells that bisects Fire Island at four locations. Long-term changes in nutrient concentrations within groundwater recharge and discharge could be monitored by annually collecting water samples from at least two observation wells in each of the four local study areas and analyzing for this constituent grouping. Monitoring the occurrence of organic compounds could coincide with the annual sampling of nutrient concentrations at these same observation wells.

\section{Acknowledgements}

The author thanks the USGS Biological Resources Discipline and NPS for support and cooperation under the Research Natural Resources Preservation Program. The assistance of many individuals is greatly appreciated. In particular, valuable coordination and assistance during the investigation were provided by former FIIS Superintendent Michael Reynolds, FIIS Chief of Resources Management \& Planning Michael Bilecki, and NPS Coastal Marine Ecologist Patricia Rafferty. Generous assistance with exploratory drilling and well installation was provided by Ronald Paulsen, Frank Basile, James DeLise, Frank Iannazzo, Ralph Milito, Dave Pertyshin, and Jonathan Wanlass of the SCDHS and William D. Capurso, Agnes P. Cwalina, Robert E. Pearsall, and Thomas F. Fitzpatrick of the USGS. Assistance with water-quality sampling was provided by Irene Abbene, Michele Abbene, Agnes P. Cwalina, Kurt T. Goetz, Thomas F. Fitzpatrick, and Erin K. O'Sullivan of the USGS. Frederick Stumm and Anthony Chu of the USGS assisted with borehole geophysical logging, and Lowell Abbadini and Agnes P. Cwalina of the USGS assisted with wellhead surveying. Helpful logistical support was provided by Steve Singler, Joe Heinrich, and Jim Dumphy of FIIS. Assistance with data compilation was provided by Diane Abell of FIIS; Henry Bokuniewicz of Stony Brook University (SBU); Mike Boufis, Paul Kuzman, and Jeff Altorfer of the SCWA; Eric Budres of the Suffolk County Department of Parks, Recreation \& Conservation;
Amy Cooper and Elizabeth Wintenberger of the New York State Office of Parks, Recreation and Historic Preservation; Robert Farmer, Andrew Rapiejko, and Robert Waters of the SCDHS; Carl Lind of the SCDP; Jack Monti, Jr. of the USGS; and Jay Tanski of New York Sea Grant. James Rumbaugh of Environmental Simulations, Inc., provided generous help with computer software support. Thoughtful comments on this manuscript were provided by Henry Bokuniewicz of SBU, Patricia Rafferty and four anonymous NPS reviewers, and Paul E. Misut and Donald A. Walter of the USGS.

\section{References Cited}

Anders, F.J., and Leatherman, S.P., 1987, Disturbance of beach sediment by off-road vehicles: Environmental Geology, v. 9 , no. 3, p. 183-189.

Bokuniewicz, H.J., McElroy, A., Schlenk, C., and Tanski, J., eds., 1993, Estuarine resources of the Fire Island National Seashore and vicinity: New York Sea Grant Institute Report NYSGI-T-93-001, 79 p. (plus appendixes).

Bokuniewicz, H.J., and Pavlik, B.L., 1990, Groundwater seepage along a barrier island: Biogeochemistry, v. 10, p. $257-276$.

Capone, D.G., and Bautista, M.F., 1985, A groundwater source of nitrate in nearshore marine sediments: Nature, v. 313, p. 214-216.

Coastal and Hydraulics Laboratory, 2006, Wave Information Studies (WIS): accessed Nov. 23, 2006, at http://frf.usace. army.mil/cgi-bin/wis/atl/atl_main.html.

Collier, Krista, 2006, Submarine groundwater discharge along a barrier island, Fire Island, NY, and its effect on sediment transport: Stony Brook, N.Y., State University of New York at Stony Brook, unpublished M.S. thesis, 48 p.

Doriski, T.P., and Wilde-Katz, Franceska, 1983, Geology of the "20-foot" clay and Gardiners Clay in southern Nassau and southwestern Suffolk Counties, Long Island, New York: U.S. Geological Survey Water-Resources Investigations Report 82-4056, 17 p.

Franke, O.L., and McClymonds, N.E., 1972, Summary of the hydrologic situation on Long Island, N.Y., as a guide to water-management alternatives: U.S. Geological Survey Professional Paper 627-F, 59 p.

Goodbred, S.L., Jr., LoCicero, P.V.R., Bonvento, V., Kolbe, S., and Holsinger, S., 2005, History of the Great South Bay estuary_Evidence for a catastrophic origin, in Geology of Long Island and Metropolitan New York: Stony Brook, N.Y., Program for the Twelfth Conference of Long Island Geologists, April 16, 2005, Program with Abstracts. 
Goodbred, S.L., Jr., and Usher, Zachary, 2001, Shallow stratigraphy of Great South Bay-Implications for the evolution of Long Island's South Shore, in Geology of Long Island and Metropolitan New York: Stony Brook, N.Y., Program for the Eighth Conference of Long Island Geologists, April 21, 2001, Program with Abstracts.

Greenhorne and O'Mara, Inc., 2003, 2002 Long Island South Shore Estuary Benthic Habitat Line Data Set: accessed January 16, 2007, at http://www.csc.noaa.gov/benthic/data/ northeast/longisl.htm.

Hanslow, D., and Nielsen, P., 1993, Shoreline setup on natural beaches, in Short, A.D., ed., Beach and surfzone morphodynamics: Journal of Coastal Research, Special Issue 15, p. 1-11.

Hem, J.D., 1985, Study and interpretation of the chemical characteristics of natural water ( $3 \mathrm{~d}$ ed.): U.S. Geological Survey Water-Supply Paper 2254, 225 p.

Hess, K.W., 2001, Generation of tidal datum fields for Tampa Bay and the New York Bight: Silver Springs, Md., U.S. Department of Commerce, National Oceanic and Atmospheric Administration, NOAA Technical Report NOS CS 11, 43 p.

Jensen, H.M., and Soren, Julian, 1974, Hydrogeology of Suffolk County, Long Island, New York: U.S. Geological Survey Hydrologic Investigation Atlas HA-501, 2 sheets, scale 1:250,000.

Jones, C.R., and Schubel, J.R., 1980, Distribution of surficial sediment and eelgrass in Great South Bay, New York (from Smith Point, west to Wantagh State Parkway): Stony Brook, N.Y., State University of New York at Stony Brook, Marine Sciences Research Center Special Report 39, Ref. 80-6, 19 p.

Klopfer, S.D., Olivero, Adele, Sneddon, Lesley, and Lundgren, Julie, 2002, Final Report of the NPS Vegetation Mapping Project at Fire Island National Seashore: Blacksburg, Va., College of Natural Resources at Virginia Tech, Conservation Management Institute Report CMI-GRS -02-03, 205 p.

Kontis, A.L., Randall, A.D., and Mazzaferro, D.L., 2004, Regional hydrology and simulation of flow of stratified-drift aquifers in the glaciated northeastern United States: U.S. Geological Survey Professional Paper 1415-C, 156 p.

Langevin, C.D., Shoemaker, W.B., and Guo, W., 2003, MODFLOW-2000, the U.S. Geological Survey Modular Ground-Water Model-Documentation of the SEAWAT-2000 Version with the Variable-Density Flow Process (VDF) and the Integrated MT3DMS Transport Process (IMT): U.S. Geological Survey Open-File Report 03-426, 43 p.
Leggette, Brashears \& Graham, Inc., 1996, Ground-water resources of Fire Island, New York: Trumbull, Conn., Leggette, Brashears \& Graham, Inc. [variously paged].

Linsley, R.K., and Franzini, J.B., 1979, Water-resources engineering: New York, McGraw-Hill, 716 p.

LoCicero, P.V.R., 2006, The history of benthic habitat and associated mollusk assemblages in Great South Bay, New York: Stony Brook, N.Y., State University of New York at Stony Brook, unpublished M.S. thesis, 77 p.

Lusczynski, N.J., 1961, Filter-press method of extracting water samples for chloride analysis: U.S. Geological Survey Water-Supply Paper 1544-A, 8 p.

Masterson, J.P., Walter, D.A., and Savoie, Jennifer, 1996, Use of particle tracking to improve numerical model calibration and to analyze ground-water flow and contaminant migration, Massachusetts Military Reservation, western Cape Cod, Massachusetts: U.S. Geological Survey OpenFile Report 96-214, $50 \mathrm{p}$.

McCobb, T.D., and Weiskel, P.K., 2003, Long-term hydrologic monitoring protocol for coastal ecosystems: U.S. Geological Survey Open-File Report 02-497, 94 p.

McNew-Cartwright, E.R., 1996, Hydrogeologic data from an investigation of water resources near Greenport, Suffolk County, New York: U.S. Geological Survey Open-File Report 95-427, 41 p.

Misut, P.E., Schubert, C.E., Bova, R.G., and Colabufo, S.R., 2004, Simulated effects of pumping and drought on groundwater levels and the freshwater-saltwater interface on the North Fork, Long Island, New York: U.S. Geological Survey Water-Resources Investigations Report 03-4184, $58 \mathrm{p}$.

Monti, Jack, Jr., and Scorca, M.P., 2003, Trends in nitrogen concentration and nitrogen loads entering the South Shore Estuary Reserve from streams and ground-water discharge in Nassau and Suffolk Counties, Long Island, New York, 1952-97: U.S. Geological Survey Water-Resources Investigations Report 02-4255, $36 \mathrm{p}$.

National Climatic Data Center, 2006, Climate Data Online: accessed February 13, 2006, at http://cdo.ncdc.noaa.gov/ $\mathrm{CDO} / \mathrm{cdo}$.

National Climatic Data Center, 2007, Climate Data Online: accessed April 6, 2007, at http://cdo.ncdc.noaa.gov/CDO/ cdo.

National Geodetic Survey, 2006, NGS DATASHEET PAGE: accessed February 8 and April 21, 2006, at http://www.ngs. noaa.gov/cgi-bin/datasheet.prl. 
National Oceanographic Data Center, 2006, NODC Interactive Data Access and Retrieval System: accessed May 18, 2006, at http://www.nodc.noaa.gov/dsdt/index.html.

National Ocean Service, 2006a, NOAA Tides and Currents-Home: accessed February 9, 2006, at http://tidesandcurrents.noaa.gov/.

National Ocean Service, 2006b, Water Level Tidal Predictions: accessed December 26, 2006, at http://tidesandcurrents. noaa.gov/tide_pred.html.

National Park Service, 2002, Mosquito Action Plan (MAP), Fire Island National Seashore-2002: accessed April 24, 2007, at http://www.nps.gov/archive/fiis/MAPfy02.htm.

National Park Service, 2003, Finding of No Significant Impact (FONSI), National Park Service (NPS) Special Use Permit Issuance for Fire Island Community Beach Scraping and Nourishment Projects: accessed April 24, 2007, at http://www.nps.gov/fiis/parkmgmt/upload/FONSI_ CommunityBeachProtectionEA_8-1-03.pdf.

National Park Service, 2007a, Fire Island National SeashorePark Statistics (U.S. National Park Service): accessed April 24, 2007, at http://www.nps.gov/fiis/parkmgmt/ statistics.htm.

Nemickas, Bronius, and Koszalka, E.J., 1982, Geohydrologic appraisal of water resources of the South Fork, Long Island, New York: U.S. Geological Survey Water-Supply Paper 2073, 55 p.

New York Sea Grant, 2007, Atlantic Coast of New York Monitoring Program Data Viewer: accessed April 27, 2007, at http://dune.seagrant.sunysb.edu/nycoast/.

Nielsen, P., 1990, Tidal dynamics of the water table in beaches: Water Resources Research, v. 26, no. 9, p. $2127-2134$.

Nielson, P., 1999, Groundwater dynamics and salinity in coastal barriers: Journal of Coastal Research, v. 15, no. 3, p. 732-740.

Nordstrom, K.F., and Jackson, N.L., 2005, Bay shoreline physical processes, Fire Island (Fire Island National Seashore Science Synthesis Paper): National Park Service Technical Report NPS/NER/NRTR—2005/020, 38 p.

Peterson, D.S., 1987, Ground-water recharge rates in Nassau and Suffolk Counties, New York: U.S. Geological Survey Water-Resources Investigations Report 86-4181, 19 p.

Pluhowski, E.J., and Kantrowitz, I.H., 1964, Hydrology of the Babylon-Islip area, Suffolk County, Long Island, N.Y.: U.S. Geological Survey Water-Supply Paper 1768, 119 p.
Pollock, D.W., 1994, User's Guide for MODPATH/ MODPATH-PLOT, Version 3: A particle tracking postprocessing package for MODFLOW, the U.S. Geological Survey finite-difference ground-water flow model: U.S. Geological Survey Open-File Report 94-464, 6 chaps.

Portnoy, J.W., Nowicki, B.L., Roman, C.T., and Urish, D.W., 1998, The discharge of nitrate-contaminated groundwater from developed shoreline to marsh-fringed estuary: Water Resources Research, v. 34, p. 3095-3104.

Schubert, C.E., 1998, Areas contributing ground water to the Peconic Estuary and ground-water budgets for the North and South Forks and Shelter Island, eastern Suffolk County, New York: U.S. Geological Survey Water-Resources Investigations Report 97-4136, 36 p., 1 pl.

Schubert, C.E., 2007, Analysis of the shallow ground-water flow system at Fire Island National Seashore, Suffolk County, New York [abs.]: in 6th Biennial Fire Island National Seashore Planning, Science and Research Conference, Abstracts of Presentations, May 9-10, 2007, p. 7.

Schubert, C.E., Buxton, H.T., and Monti, Jack, Jr., 1997, Ground-water resource evaluation on Long Island, New York, using flow models and a geographic information system: U.S. Geological Survey Fact Sheet FS-239-96, $4 \mathrm{p}$.

Schwab, W.C., Thieler, E.R., Allen, J.R., Foster, D.S., Swift, B.A., and Denny, J.F., 2000, Influence of innercontinental shelf geologic framework on the evolution and behavior of the barrier-island system between Fire Island Inlet and Shinnecock Inlet, Long Island, New York: Journal of Coastal Research, v. 16, no. 2, p. 408-422.

Scorca, M.P., and Monti, Jack, Jr., 2001, Estimates of nitrogen loads entering Long Island Sound from ground water and streams on Long Island, New York, 1985-96: U.S. Geological Survey Water-Resources Investigations Report 00-4196, 29 p.

Scorca, M.P., Reilly, T.E., and Franke, O.L., 1995, Selected hydrogeologic and water-quality data from Jones Beach Island, Long Island, New York: U.S. Geological Survey Water-Resources Investigations Report 92-4171, 21 p.

Simmons, D.L., 1986, Geohydrology and ground-water quality on Shelter Island, Suffolk County, Long Island, New York, 1983-1984: U.S. Geological Survey WaterResources Investigation Report 85-4165, 39 p.

Smolensky, D.A., Buxton, H.T., and Shernoff, P.K., 1989, Hydrologic framework of Long Island, New York: U.S. Geological Survey Hydrologic Investigations Atlas HA-709, 3 sheets, scale 1:250,000. 
Steenhuis, T.S., Jackson, C.D., Kung, S.K.J., and Brutsaert, Wilfried, 1985, Measurement of groundwater recharge on eastern Long Island, New York, USA: Journal of Hydrology, v. 79, p. 145-169.

Todd, D.K., 1980, Groundwater hydrology (2d ed.): New York, John Wiley and Sons, 535 p.

Turner, I.L., Coates, B.P., and Acworth, R.I., 1996, The effects of tides and waves on water-table elevations in coastal zones: Hydrogeology Journal, v. 4, no. 2, p. 51-69.

U.S. Department of Commerce, 1969, Tide tables 1970 high and low water predictions - East Coast of North and South America including Greenland: Environmental Science Services Administration, Coast and Geodetic Survey, 290 p.

U.S. Geological Survey, variously dated, National field manual for the collection of water-quality data: U.S. Geological Survey Techniques of Water-Resources Investigations, book 9, chaps. A1-A9, available at http://pubs.water.usgs. gov/twri9A.

Valiela, Ivan, Foreman, Kenneth, LaMontagne, Michael, Hersh, Douglas, Costa, Joseph, Peckol, Paulette, DeMeoAndreson, Barbara, D'Avanzo, Charlene, Babione, Michele, Sham, Chi-Ho, Brawley, John, and Lajtha, Kate, 1992, Couplings of watersheds and coastal waters: sources and consequences of nutrient enrichment in Waquoit Bay, Massachusetts: Estuaries and Coasts, v. 15, no. 4, p. $443-457$.

White, W.N., 1932, A method of estimating groundwater supplies based on discharge by plants and evaporation from soil: U.S. Geological Survey Professional Paper 659-A, p. $1-105$. 
This page has been left blank intentionally. 


\section{Glossary}

\section{A}

aquifer An underground layer of waterbearing permeable rock or unconsolidated materials (gravel, sand, silt, or clay) from which groundwater can be usefully extracted using a water well.

aquifer system A heterogeneous body of permeable and less permeable material that acts as a water-yielding hydraulic unit of regional extent.

\section{B}

barrier island A long, narrow, sandy coastal island, representing a broadened barrier beach that is above high tide and parallel to the shore and that commonly has dunes and marshy terranes extending landward from the beach.

\section{C}

consumptive use Removal of water from the water environment by evaporation, transpiration, incorporation into products or crops, or consumption by man or livestock (Solley and others, 1983).

contributing area The land area through or over which rainwater and other surface water soaks through the ground to replenish an aquifer, stream, river, lake, wetland, or estuary. This can also be called "recharge area."

\section{D}

discharge zone An area in which subsurface water, including both groundwater and vadose water, is discharged to the land surface, to bodies of surface water, or to the atmosphere.

\section{E}

evaporation The process, also called vaporization, by which a substance passes from the liquid or solid state to the vapor state. evapotranspiration Loss of water from a land area through transpiration of plants and evaporation from the soil and surfacewater bodies.

\section{$\mathbf{F}$}

freshwater Water containing less than 1,000 milligrams per liter of dissolved solids; generally, water with more than $500 \mathrm{mg} / \mathrm{L}$ is undesirable for drinking and for many industrial uses (Solley and others, 1983).

\section{G}

geophysical surveying The use of one or more geophysical techniques in geophysical exploration, such as earth currents, electrical, gravity, or electromagnetic methods, heat flow, magnetics, radioactivity, and seismics.

groundwater budget A numerical account of the recharge, discharge, and changes in storage of an aquifer, part of an aquifer, or system of aquifers.

groundwater divide A ridge in the water table or other potentiometric surface from which the groundwater represented by that surface moves away in both directions. Water in other aquifers above or below, and even in the lower part of the same aquifer, may have a potentiometric surface lacking the ridge, and so may flow past the divide.

groundwater level The elevation of the water table or another potentiometric surface at a particular place or in a particular area, as represented by the level of water in wells or other natural or artificial openings or depressions communicating with the saturated zone.

groundwater movement The movement, or flow, of water in the saturated zone, whether naturally or artificially induced.

groundwater reservoir An underground layer of water-bearing permeable rock or unconsolidated materials (gravel, sand, silt, or clay) in which groundwater is stored. The upper surface of the groundwater reservoir is known as the water table. Changes in the water table represent a change in the storage of the reservoir. 
H

hydraulic conductivity The rate at which water can move through an aquifer or other permeable medium.

hydraulic gradient In an aquifer, the rate of change of total head per unit of distance of flow at a given point and in a given direction.

hydraulic head The height of the free surface of a body of water above a given subsurface point.

hydrogeology The science that deals with subsurface waters and with related geologic aspects of surface waters.

\section{I}

infiltration The process by which water penetrates through the ground surface into and through the porous medium (evolved from consolidated rocks, sediments, glacial tills, and organic matter).

\section{L}

lacustrine Pertaining to, produced by, or formed in a lake or lakes; for example, "lacustrine sands" deposited on the bottom of a lake, or a "lacustrine terrace" formed along its margin.

\section{0}

observation well A nonpumping well that is used to observe the elevation of the water table or other potentiometric surface. It may be used temporarily during a pumping test or as a long-term monitoring well.

\section{R}

recharge The processes involved in the addition of water to the saturated zone, naturally by precipitation or runoff, or artificially by spreading or injection; also, the amount of water added.

recharge area An area beneath which water reaches the saturated zone following infiltration and percolation. Beneath it, downward components of hydraulic head exist and groundwater moves downward into deeper parts of the aquifer.

\section{S}

shallow well A water well that taps the shallowest aquifer in the vicinity. The water is generally unconfined groundwater.

surface runoff Water that flows across surfaces, rather than soaking into the ground, and eventually enters a stream, river, lake, wetland, or estuary.

\section{T}

tidal pumping The action of tides on sloping sand beaches that causes the water-table height (elevation) to rise above mean sea level.

\section{W}

water table The surface between the saturated zone and the unsaturated zone; that surface of a body of unconfined groundwater at which the pressure is equal to that of the atmosphere.

water-table overheight The difference between the average water-table height (elevation) and the mean sea level, caused by the action of tides on sloping sandy beaches (tidal pumping) and wave setup.

wave setdown A decrease in the mean water level in the region in which breakers form near the seashore, caused by the presence of a pressure field.

wave setup An increase in the mean water level shoreward of the region in which breakers form at the seashore, caused by the onshore flux of momentum against the beach.

\section{References}

Solley, W.B., Chase, E.B., and Mann, W.B., IV, 1983, Estimated use of water in the United States in 1980: U.S. Geological Survey Circular 1001, 56 p. 
Appendix 1. Groundwater levels collected at Fire Island National Seashore, October 2005 through October 2006.

[Water levels are in meters above National Geodetic Vertical Datum of 1929. Well locations are shown in figure 4. Well number is assigned by New York State Department of Environmental Conservation; prefix "S" denoting Suffolk County is omitted]

\begin{tabular}{|c|c|c|c|c|c|c|}
\hline \multirow{2}{*}{$\begin{array}{c}\text { Local well } \\
\text { number }\end{array}$} & \multicolumn{2}{|c|}{ October-November 2005 water level } & \multicolumn{2}{|c|}{ March 2006 water level } & \multicolumn{2}{|c|}{ October 2006 water level } \\
\hline & Date & Level & Date & Level & Date & Level \\
\hline \multicolumn{7}{|c|}{ KISMET } \\
\hline 125370 & $11 / 1 / 2005$ & 0.52 & $3 / 29 / 2006$ & 0.47 & $10 / 4 / 2006$ & 0.48 \\
\hline 125371 & $11 / 1 / 2005$ & 0.98 & $3 / 29 / 2006$ & 1.19 & $10 / 4 / 2006$ & 1.10 \\
\hline 125981 & $11 / 1 / 2005$ & 1.05 & $3 / 29 / 2006$ & 1.03 & $10 / 4 / 2006$ & 1.07 \\
\hline 125983 & $11 / 1 / 2005$ & 0.92 & $3 / 29 / 2006$ & 1.02 & $10 / 4 / 2006$ & 1.03 \\
\hline 125984 & $11 / 1 / 2005$ & 0.90 & $3 / 29 / 2006$ & 0.82 & $10 / 4 / 2006$ & 0.90 \\
\hline 125985 & $11 / 1 / 2005$ & 0.92 & $3 / 29 / 2006$ & 0.85 & $10 / 4 / 2006$ & 0.91 \\
\hline 125986 & $11 / 1 / 2005$ & 1.00 & $3 / 29 / 2006$ & 1.07 & $10 / 4 / 2006$ & 1.06 \\
\hline 125995 & $11 / 1 / 2005$ & 0.98 & $3 / 29 / 2006$ & 1.05 & $10 / 4 / 2006$ & 1.03 \\
\hline 126753 & $11 / 1 / 2005$ & 1.00 & $3 / 29 / 2006$ & 1.07 & $10 / 4 / 2006$ & 1.06 \\
\hline \multicolumn{7}{|c|}{ ROBBINS REST } \\
\hline 125982 & $11 / 1 / 2005$ & 0.75 & $3 / 29 / 2006$ & 1.02 & $10 / 4 / 2006$ & 0.73 \\
\hline 125994 & $11 / 1 / 2005$ & 0.77 & $3 / 29 / 2006$ & 1.11 & $10 / 4 / 2006$ & 0.75 \\
\hline 125996 & $11 / 1 / 2005$ & 0.65 & $3 / 29 / 2006$ & 0.73 & $10 / 4 / 2006$ & 0.59 \\
\hline 125997 & $11 / 1 / 2005$ & 0.71 & $3 / 29 / 2006$ & 0.83 & $10 / 4 / 2006$ & 0.67 \\
\hline 125998 & $11 / 1 / 2005$ & 0.75 & $3 / 29 / 2006$ & 0.96 & $10 / 4 / 2006$ & 0.71 \\
\hline 125999 & $11 / 1 / 2005$ & 0.80 & $3 / 29 / 2006$ & 0.95 & $10 / 4 / 2006$ & 0.78 \\
\hline 126000 & $11 / 1 / 2005$ & 0.75 & $3 / 29 / 2006$ & 1.02 & $10 / 4 / 2006$ & 0.73 \\
\hline 126001 & $11 / 1 / 2005$ & 0.69 & $3 / 29 / 2006$ & 0.93 & $10 / 4 / 2006$ & 0.69 \\
\hline \multicolumn{7}{|c|}{ WATCH HILL } \\
\hline 125380 & $10 / 31 / 2005$ & 0.87 & $3 / 28 / 2006$ & 1.03 & $10 / 3 / 2006$ & 1.13 \\
\hline 125381 & $10 / 31 / 2005$ & 0.86 & $3 / 28 / 2006$ & 0.86 & $10 / 3 / 2006$ & 0.92 \\
\hline 125382 & $10 / 31 / 2005$ & 0.83 & $3 / 28 / 2006$ & 0.83 & $10 / 3 / 2006$ & 0.84 \\
\hline 125383 & $10 / 31 / 2005$ & 0.93 & $3 / 28 / 2006$ & 0.97 & $10 / 3 / 2006$ & 1.05 \\
\hline 125384 & $10 / 31 / 2005$ & 0.91 & $3 / 28 / 2006$ & 0.91 & $10 / 3 / 2006$ & 1.01 \\
\hline 125385 & $10 / 31 / 2005$ & 0.94 & $3 / 28 / 2006$ & 0.91 & $10 / 3 / 2006$ & 1.04 \\
\hline 125386 & $10 / 31 / 2005$ & 0.83 & $3 / 28 / 2006$ & 0.94 & $10 / 3 / 2006$ & 1.02 \\
\hline 125387 & $10 / 31 / 2005$ & 0.79 & $3 / 28 / 2006$ & 0.78 & $10 / 3 / 2006$ & 0.75 \\
\hline 125990 & $10 / 31 / 2005$ & 0.92 & $3 / 28 / 2006$ & 0.97 & $10 / 3 / 2006$ & 1.05 \\
\hline \multicolumn{7}{|c|}{ NATIONAL WILDERNESS } \\
\hline 124399 & $10 / 31 / 2005$ & 0.88 & $3 / 28 / 2006$ & 0.90 & $10 / 3 / 2006$ & 0.91 \\
\hline 124400 & $10 / 31 / 2005$ & 0.96 & $3 / 28 / 2006$ & 0.82 & $10 / 3 / 2006$ & 0.90 \\
\hline 125363 & $10 / 31 / 2005$ & 0.73 & $3 / 28 / 2006$ & 0.95 & $10 / 3 / 2006$ & 0.83 \\
\hline 125364 & $10 / 31 / 2005$ & 0.71 & $3 / 28 / 2006$ & 0.87 & $10 / 3 / 2006$ & 0.77 \\
\hline 125365 & $10 / 31 / 2005$ & 0.61 & $3 / 28 / 2006$ & 0.66 & $10 / 3 / 2006$ & 0.56 \\
\hline 125366 & $10 / 31 / 2005$ & 0.66 & $3 / 28 / 2006$ & 0.78 & $10 / 3 / 2006$ & 0.68 \\
\hline 125367 & $10 / 31 / 2005$ & 0.81 & $3 / 28 / 2006$ & 0.96 & $10 / 3 / 2006$ & 0.88 \\
\hline 125368 & $10 / 31 / 2005$ & 0.69 & $3 / 28 / 2006$ & 0.93 & $10 / 3 / 2006$ & 0.78 \\
\hline 125369 & $10 / 31 / 2005$ & 0.77 & $3 / 28 / 2006$ & 0.87 & $10 / 3 / 2006$ & 0.77 \\
\hline
\end{tabular}


Appendix 2. Dissolved inorganic nitrogen (ammonia, nitrite, and nitrite plus nitrate) and phosphorus (orthophosphate) concentrations in groundwater collected at Fire Island National Seashore, October 2005 through September 2006.

[Well locations are shown in figure 4. Well number is assigned by New York State Department of Environmental Conservation; prefix "S" denoting Suffolk County is omitted. E, estimated; mg/L, milligrams per liter; N, nitrogen; P, phosphorus; <, less than]

\begin{tabular}{|c|c|c|c|c|c|}
\hline $\begin{array}{l}\text { Local well } \\
\text { number }\end{array}$ & Date of sample & $\begin{array}{l}\text { Ammonia, } \\
\mathrm{mg} / \mathrm{L} \text { as } \mathrm{N}\end{array}$ & $\begin{array}{c}\text { Nitrite plus nitrate, } \\
\mathrm{mg} / \mathrm{L} \text { as } \mathrm{N}\end{array}$ & $\begin{array}{c}\text { Nitrite, } \\
\mathrm{mg} / \mathrm{L} \text { as } \mathrm{N}\end{array}$ & $\begin{array}{c}\text { Orthophosphate, } \\
\text { mg/L as } P\end{array}$ \\
\hline \multicolumn{6}{|c|}{ KISMET } \\
\hline \multirow[t]{3}{*}{125370} & $10 / 20 / 2005$ & 1.29 & E0.03 & E0.006 & 0.57 \\
\hline & $3 / 1 / 2006$ & 3.63 & $<0.06$ & 0.021 & 1.6 \\
\hline & $8 / 30 / 2006$ & 0.527 & $<0.06$ & 0.008 & 0.469 \\
\hline \multirow[t]{2}{*}{125371} & $10 / 20 / 2005$ & E0.03 & 0.74 & 0.021 & 0.14 \\
\hline & $8 / 30 / 2006$ & 0.023 & 0.1 & 0.014 & 0.18 \\
\hline \multirow[t]{2}{*}{125981} & $10 / 20 / 2005$ & 0.07 & $<0.06$ & $<0.008$ & $<0.02$ \\
\hline & $8 / 30 / 2006$ & 0.091 & $<0.06$ & E0.002 & 0.02 \\
\hline 125983 & $10 / 24 / 2005$ & 0.29 & $<0.06$ & 0.009 & 0.8 \\
\hline 125984 & $10 / 24 / 2005$ & E0.03 & $<0.06$ & 0.013 & 0.35 \\
\hline \multirow[t]{2}{*}{125985} & $10 / 24 / 2005$ & 0.07 & $<0.06$ & $<0.008$ & 1.05 \\
\hline & $8 / 30 / 2006$ & E0.01 & $<0.06$ & E0.001 & 0.452 \\
\hline \multirow[t]{2}{*}{125986} & $10 / 24 / 2005$ & 0.17 & $<0.06$ & 0.009 & 0.08 \\
\hline & $8 / 30 / 2006$ & 0.436 & $<0.06$ & 0.005 & 0.107 \\
\hline 125995 & $10 / 24 / 2005$ & 0.24 & $<0.06$ & 0.014 & 0.04 \\
\hline \multirow[t]{2}{*}{126753} & $10 / 24 / 2005$ & 0.84 & 4.5 & 0.066 & 0.13 \\
\hline & $8 / 30 / 2006$ & 0.039 & 1.89 & 0.024 & 0.131 \\
\hline \multicolumn{6}{|c|}{ ROBBINS REST } \\
\hline \multirow[t]{2}{*}{125982} & $10 / 31 / 2005$ & 0.18 & $<0.06$ & E0.006 & 0.1 \\
\hline & $8 / 23 / 2006$ & 0.116 & $<0.06$ & E0.002 & 0.088 \\
\hline \multirow[t]{2}{*}{125994} & $10 / 31 / 2005$ & $<0.04$ & 0.83 & $<0.008$ & 0.04 \\
\hline & $8 / 23 / 2006$ & $<0.01$ & 1.19 & $<0.002$ & 0.034 \\
\hline \multirow[t]{3}{*}{125996} & $10 / 31 / 2005$ & 0.22 & $<0.06$ & $<0.008$ & 0.28 \\
\hline & $3 / 1 / 2006$ & $<0.04$ & $<0.06$ & $<0.008$ & 0.09 \\
\hline & $8 / 23 / 2006$ & 0.016 & $<0.06$ & 0.004 & 0.199 \\
\hline \multirow[t]{2}{*}{125997} & $10 / 31 / 2005$ & 0.44 & $<0.06$ & 0.016 & 0.19 \\
\hline & $8 / 23 / 2006$ & 0.053 & $<0.06$ & 0.003 & 0.151 \\
\hline \multirow[t]{2}{*}{125998} & $10 / 31 / 2005$ & E0.04 & $<0.06$ & $<0.008$ & 0.12 \\
\hline & $8 / 23 / 2006$ & 0.019 & $<0.06$ & 0.003 & 0.131 \\
\hline 125999 & $10 / 31 / 2005$ & 0.38 & $<0.06$ & E0.005 & 0.07 \\
\hline \multirow[t]{2}{*}{126000} & $10 / 31 / 2005$ & 0.11 & 0.87 & 0.133 & 0.06 \\
\hline & $8 / 23 / 2006$ & 0.094 & $<0.06$ & 0.007 & 0.101 \\
\hline 126001 & $10 / 31 / 2005$ & 0.13 & $<0.06$ & $<0.008$ & $<0.02$ \\
\hline
\end{tabular}


Appendix 2. Dissolved inorganic nitrogen (ammonia, nitrite, and nitrite plus nitrate) and phosphorus (orthophosphate) concentrations in groundwater collected at Fire Island National Seashore, October 2005 through September 2006. - Continued

[Well locations are shown in figure 4. Well number is assigned by New York State Department of Environmental Conservation; prefix "S" denoting Suffolk County is omitted. E, estimated; mg/L, milligrams per liter; $\mathrm{N}$, nitrogen; $\mathrm{P}$, phosphorus; <, less than]

\begin{tabular}{|c|c|c|c|c|c|}
\hline $\begin{array}{l}\text { Local well } \\
\text { number }\end{array}$ & Date of sample & $\begin{array}{l}\text { Ammonia, } \\
\mathrm{mg} / \mathrm{L} \text { as N }\end{array}$ & $\begin{array}{c}\text { Nitrite plus nitrate, } \\
\text { mg/L as N }\end{array}$ & $\begin{array}{c}\text { Nitrite, } \\
\text { mg/L as N }\end{array}$ & $\begin{array}{c}\text { Orthophosphate, } \\
\text { mg/L as P }\end{array}$ \\
\hline \multicolumn{6}{|c|}{ WATCH HILL } \\
\hline \multirow[t]{2}{*}{125380} & $10 / 17 / 2005$ & 9.17 & $<0.06$ & E0.004 & 0.94 \\
\hline & 9/20/2006 & 10.1 & $<0.06$ & E0.002 & 1.06 \\
\hline 125381 & $10 / 11 / 2005$ & 0.74 & E0.03 & $<0.008$ & 0.14 \\
\hline 125382 & $10 / 17 / 2005$ & 0.64 & $<0.06$ & $<0.008$ & 0.24 \\
\hline \multirow[t]{2}{*}{125383} & $10 / 11 / 2005$ & 4.66 & $<0.06$ & 0.008 & 0.66 \\
\hline & 9/20/2006 & 5.27 & $<0.06$ & 0.003 & 0.427 \\
\hline \multirow[t]{2}{*}{125384} & $10 / 11 / 2005$ & 9.4 & $<0.06$ & $<0.008$ & 1.97 \\
\hline & 9/20/2006 & 5.1 & $<0.06$ & 0.002 & 1.05 \\
\hline 125385 & $10 / 17 / 2005$ & 0.82 & $<0.06$ & $<0.008$ & 0.13 \\
\hline \multirow[t]{3}{*}{125386} & $10 / 11 / 2005$ & 1.57 & $<0.06$ & $<0.008$ & 0.29 \\
\hline & 9/20/2006 & 1.21 & $<0.06$ & 0.003 & 0.145 \\
\hline & $9 / 20 / 2006$ & 1.23 & $<0.06$ & 0.003 & 0.134 \\
\hline \multirow[t]{3}{*}{125387} & $10 / 17 / 2005$ & 0.08 & 0.08 & 0.034 & 0.05 \\
\hline & $3 / 1 / 2006$ & E0.04 & $<0.06$ & 0.015 & 0.15 \\
\hline & $9 / 20 / 2006$ & 0.139 & E0.05 & 0.028 & 0.085 \\
\hline \multirow[t]{2}{*}{125990} & $10 / 11 / 2005$ & 7.17 & $<0.06$ & $<0.008$ & 1.64 \\
\hline & 9/20/2006 & 6.6 & $<0.06$ & 0.003 & 2.51 \\
\hline \multicolumn{6}{|c|}{ NATIONAL WILDERNESS } \\
\hline 124399 & $10 / 13 / 2005$ & 0.12 & $<0.06$ & $<0.008$ & 0.09 \\
\hline 124400 & $10 / 18 / 2005$ & $<0.04$ & 0.67 & E0.005 & $<0.04$ \\
\hline \multirow[t]{2}{*}{125363} & $10 / 18 / 2005$ & E0.04 & 0.99 & $<0.008$ & $<0.02$ \\
\hline & $8 / 17 / 2006$ & E0.009 & 0.25 & $<0.002$ & 0.015 \\
\hline \multirow[t]{2}{*}{125364} & $10 / 18 / 2005$ & $<0.04$ & 0.08 & $<0.008$ & 0.07 \\
\hline & $8 / 17 / 2006$ & 0.012 & 0.17 & $<0.002$ & 0.081 \\
\hline \multirow[t]{3}{*}{125365} & $10 / 19 / 2005$ & $<0.04$ & 0.08 & $<0.008$ & 0.03 \\
\hline & $3 / 1 / 2006$ & $<0.04$ & 0.12 & $<0.008$ & $<0.02$ \\
\hline & $8 / 17 / 2006$ & 0.034 & 0.51 & 0.004 & 0.058 \\
\hline \multirow[t]{2}{*}{125366} & $10 / 19 / 2005$ & $<0.04$ & 0.47 & $<0.008$ & 0.07 \\
\hline & $8 / 17 / 2006$ & E0.009 & 0.3 & $<0.002$ & 0.05 \\
\hline \multirow[t]{2}{*}{125367} & $10 / 18 / 2005$ & E0.03 & 0.26 & $<0.008$ & $<0.02$ \\
\hline & $8 / 17 / 2006$ & E0.009 & E0.06 & E0.001 & E0.006 \\
\hline \multirow[t]{2}{*}{125368} & $10 / 19 / 2005$ & E0.03 & 0.25 & $<0.008$ & $<0.02$ \\
\hline & $8 / 17 / 2006$ & 0.023 & 0.08 & $<0.002$ & 0.008 \\
\hline \multirow[t]{2}{*}{125369} & $10 / 18 / 2005$ & $<0.04$ & 0.82 & $<0.008$ & 0.02 \\
\hline & $8 / 17 / 2006$ & 0.011 & 0.33 & E0.001 & 0.089 \\
\hline
\end{tabular}


This page has been left blank intentionally. 
This page has been left blank intentionally. 
This page has been left blank intentionally. 
Prepared by the Pembroke and West Trenton Publishing Service Centers.

For additional information write to: New York Water Science Center

U.S. Geological Survey

2045 Route 112, Bldg. 4

Coram, NY 11727

Information requests:

(518) 285-5602

or visit our Web site at: http://ny.water.usgs.gov 


\section{这}

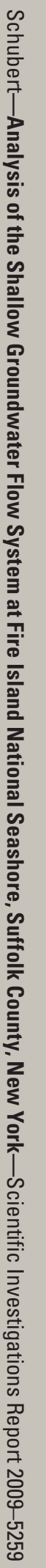

Printed on recycled paper 